Universidade de São Paulo

Instituto de Química de São Carlos

ÉSTERES DE CELULOSE: SÍNTESE, PROPRIEDADES E PREPARAÇÃO DE MANTAS E ESFERAS VISANDO APLICAÇÕES EM IMOBILIZAÇÃO DE LIPASE

ROBERTA TEIXEIRA POLEZ 

ROBERTA TEIXEIRA POLEZ

\section{ÉSTERES DE CELULOSE: SÍNTESE, PROPRIEDADES E PREPARAÇÃO DE MANTAS E ESFERAS VISANDO APLICAÇÕES EM IMOBILIZAÇÃO DE LIPASE}

Dissertação apresentada ao Instituto de Química de São Carlos, da Universidade de São Paulo, como parte dos requisitos para a obtenção do título de Mestre em Ciências

Área de concentração: Físico-Química

Orientadora: Prof ${ }^{\mathrm{a}}$. Dr ${ }^{\mathrm{a}}$. Elisabete Frollini

São Carlos 

I stand on the sacrifices of a million women before me thinking what can I do to make this mountain taller so the women after me can see farther

$$
\text { legacy - Rupi Kaur }
$$

The Sun and Her Flowers 



\section{AGRADECIMENTOS}

À Prof. ${ }^{a}$. Elisabete Frollini por toda a orientação, dedicação e apoio nesses anos de trabalho. Pelo incentivo e ensinamentos que contribuíram para meu amadurecimento profissional e pessoal, e por me transmitir o entusiasmo pela ciência. Fica aqui meu eterno agradecimento e admiração.

Aos meus pais, Rozana e Romualdo, e meu irmão, Rodrigo, que me apoiaram sempre.

A todos do Grupo de Materiais Macromoleculares e Fibras Lignocelulósicas, de curta ou longa data: Joice, Bianca, Deyvid, Roberta, Ana, Gleyci, Claudia, Lucas, Thamiris, Lidi, Rachel, Érika e Dani (espero não ter esquecido ninguém); por toda a convivência e companheirismo, especialmente nos momentos de café e descontração. Obrigada por tornarem a vida mais leve.

Ao Prof. Omar El Seoud (IQ-USP) que por meio de sua colaboração ajudou no desenvolvimento deste trabalho.

Ao Prof. André Meleiro Porto (IQSC-USP) e seu aluno de doutorado Samuel Cardoso de Paula, que por meio de sua colaboração ajudaram a concluir este trabalho.

Ao Dr. Luiz Antonio Ramos, técnico do Grupo de Físico Química-Orgânica, pela realização das análises térmicas.

Aos técnicos da Central de Análises Químicas (CAQI-USP): Dr. Marcio de Paula, Dra. Sylvana Cardoso, MSc. André Tognon, Dr. Marcelo Calegari, MSc. Carlos Alberto Bento e Aldimar Constante pelas análises realizadas. Aos demais funcionários da Secretaria de PósGraduação, Oficina de Vidros e Oficina Mecânica pelos serviços prestados e pela atenção dedicada.

À Universidade de São Paulo e ao Instituto de Química de São Carlos pelo suporte para realização deste trabalho.

A todos aqueles que contribuíram direta ou indiretamente para a realização desta dissertação. 



\section{RESUMO}

O presente estudo teve como uma das metas a esterificação da celulose de linter de algodão em meio homogêneo, usando como sistema de solvente cloreto de lítio/N,Ndimetilacetamida ( $\mathrm{LiCl} / \mathrm{DMAc}$ ), e anidrido hexanóico ou cloreto de benzoíla como agentes esterificantes. A celulose de linter de algodão foi utilizada por ser uma fonte de rápido crescimento e considerada a celulose de maior pureza isolada de fontes vegetais. Na síntese de ésteres de celulose (hexanoato, benzoato, bem com ésteres mistos, hexanoato-benzoato de celulose) visou-se obter diferentes graus médios de substituição ( $\mathrm{GS}=1,2$ e 3) por meio do

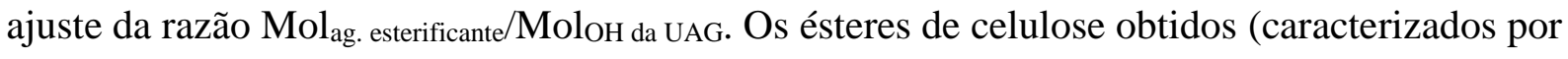
FTIR, RMN- ${ }^{1} \mathrm{H}$ e TGA) foram utilizados como materiais de partida na preparação de mantas (mats) e esferas, o que correspondeu a uma segunda meta do estudo. As mantas de hexanoato de celulose foram obtidas por meio da técnica de eletrofiação a partir de soluções de tetraidrofurano/N,N-dimetilacetamida (THF/DMAc), e mantas de benzoato de celulose e hexanoato-benzoato foram preparadas a partir de soluções de ácido trifluoroacético (TFA). A eletrofiação resultou em redes de fibras ultrafinas (> $100 \mathrm{~nm}$ ) em um amplo intervalo de diâmetro, em decorrência da variação das condições experimentais como taxa de fluxo da solução polimérica $\left(5,5,15,5\right.$ e 45,5 $\left.\mu \mathrm{L} \cdot \mathrm{min}^{-1}\right)$, distância de trabalho $(5,10,15$ e $25 \mathrm{~cm})$, tensão aplicada entre agulha e coletor $(10,15,20$ e $25 \mathrm{kV})$ e concentração da solução polimérica (7, 9, 11,13 e $15 \%$ ). Ao avaliar as micrografias de MEV, observou-se que um menor fluxo de injeção favoreceu a formação de fibras ultrafinas com diâmetros médios de até $150 \mathrm{~nm}$. As esferas foram preparadas por meio de gotejamento de uma solução de éster de celulose e acetona em não-solvente (água ou metanol). As esferas obtidas em água apresentaram diâmetros ligeiramente maiores e superfícies menos rugosas, quando comparadas às esferas obtidas em metanol. Mantas e esferas de ésteres de celulose, selecionadas a partir dos resultados das respectivas caracterizações, foram utilizados como suporte para imobilização de lipases de Pseudomonas fluorescens (LPF) por encapsulamento, e posteriormente, aplicados na resolução cinética enzimática de cloridrinas racêmicas por meio de reação com acetato de vinila catalisada por lipase imobilizada, sendo esta etapa correspondente à terceira meta deste estudo. A resolução cinética foi analisada por Cromatógrafo a Gás acoplado a um detector de ionização de chama (CG-DIC) para a determinação dos parâmetros da reação. A lipase referência, não imobilizada, apresentou conversão moderada $(c=34 \%)$, excelente pureza enantiomérica ( $e e_{p}$ $=98 \%)$ e excelente razão enantiomérica $(\mathrm{E}=212)$. Lipase imobilizada em mantas não apresentou atividade catalítica, provavelmente devido à tensão aplicada durante a eletrofiação, o que pode ter inativados as enzimas, e/ou devido à aplicação das mantas sobre suporte, o que pode ter prejudicado o acesso às enzimas. Para esferas de Hex 12 (15\% LPF) obtidas usando água como não-solvente, os resultados se mostraram promissores apresentando conversão superior após $120 \mathrm{~h}$ de reação $(c=40 \%)$ e pureza enantiomérica do produto $94 \%$. Reutilizando as esferas em um segundo ciclo, observou-se uma redução de $24 \%$ da taxa de conversão de reação.

Palavras chave: celulose de linter; ésteres de celulose; eletrofiação; esferas; imobilização enzimática. 


\begin{abstract}
The aim of the present study was the esterification of cotton linter cellulose in homogeneous medium, using as solvent system lithium chloride/ $\mathrm{N}, \mathrm{N}$-dimethylacetamide (LiCl/DMAc), and hexanoic anhydride or benzoyl chloride as esterifying agents. Cotton linter cellulose was used because it is a fast-growing source and is considered the highest purity cellulose isolated from plant sources. The synthesis of cellulose esters (hexanoate, benzoate as well as mixed esters, cellulose hexanoate-benzoate) aimed to obtain different average degrees

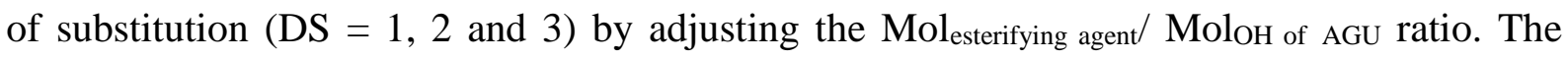
obtained cellulose esters (characterized by FTIR, ${ }^{1} \mathrm{H}$ NMR, and TGA) were used as starting materials in the preparation of mats and spheres, which corresponded to a second goal of the study. Cellulose hexanoate mats were obtained by electrospinning technique from tetrahydrofuran/N,N-dimethylacetamide (THF/DMAc) solutions, and cellulose benzoate and hexanoate benzoate mats were prepared from trifluoroacetic acid (TFA) solutions. Electrospinning resulted in ultrathin fiber networks (>100 nm) over a wide diameter range by varying the experimental conditions such as polymeric solution flow rate $(5.5,15.5$ and 45.5 $\left.\mu \mathrm{L} . \mathrm{min}^{-1}\right)$, distance $(5,10,15$ and $25 \mathrm{~cm})$, applied voltage between needle and collector $(10,15$, 20 and $25 \mathrm{kV}$ ) and polymeric solution concentration (7, 9, 11, 13 and 15\%). When evaluating SEM micrographs, it was observed that a smaller injection flow favored the formation of ultrathin fibers up to $150 \mathrm{~nm}$. The spheres were prepared by dripping a solution of cellulose ester and acetone in non-solvent (water or methanol). The spheres obtained in water had slightly larger diameters and less rough surface when compared to spheres obtained in methanol. Mats and spheres of cellulose esters, selected from the results of the respective characterizations, were used as supports for immobilization of Pseudomonas fluorescens lipases (PFL) by encapsulation and subsequently applied to the enzymatic kinetic resolution of racemic hydrochlorins by reaction with vinyl acetate catalyzed by immobilized lipase, this step is the third goal of this study. The kinetic resolution was analyzed by Gas Chromatography coupled to a flame ionization detector (GC-FID) to determine the reaction parameters. The nonimmobilized reference lipase showed moderate conversion $(c=34 \%)$, excellent enantiomeric purity $\left(e e_{p}=98 \%\right)$ and excellent enantiomeric ratio $(\mathrm{E}=212)$. Lipase immobilized in mats did not show catalytic activity, probably due to the voltage applied during electroporation, which may have inactivated the enzymes, and/or the application of the blankets on support, which may have impaired enzyme access. For Hex 12 beads (15\% LPF) obtained using water as a counter solvent, the results were promising, superior conversion after $120 \mathrm{~h}$ reaction $(c=40 \%)$ and $94 \%$ enantiomeric purity. By reusing the spheres in a second cycle, a $24 \%$ reduction in the reaction conversion rate was observed.
\end{abstract}

Keywords: linter cellulose; cellulose esters; electrospinning; spheres; enzymatic immobilization. 


\section{LISTA DE FIGURAS}

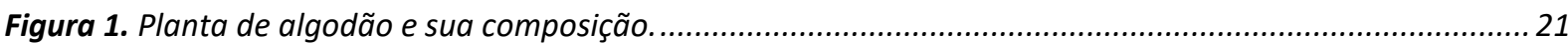

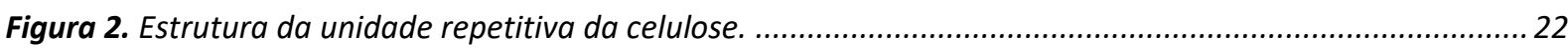

Figura 3. Representações das ligações hidrogênio intra e intermoleculares da celulose. ................................. 23

Figura 4. Partes hidrofílicas e hidrofóbicas da molécula de celulose. .........................................................24

Figura 5. Regiões cristalinas e não cristalinas em estrutura de microfibrila de celulose. ..................................25

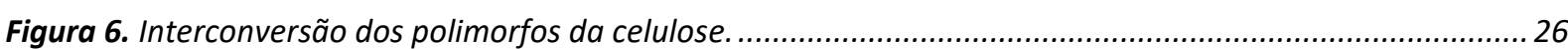

Figura 7. Mecanismo do rearranjo das cadeias celulose em mercerização. ...................................................2 27

Figura 8. Mecanismo de intumescimento da celulose com água...............................................................28

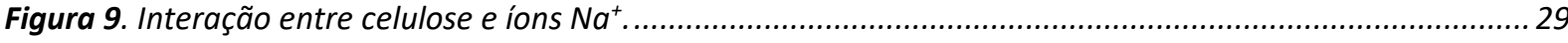

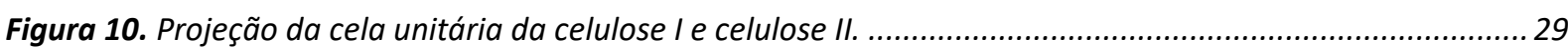

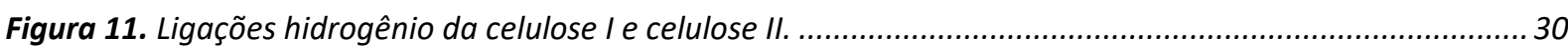

Figura 12. Representação esquemática do arranjo das cadeias poliméricas em diferentes estágios da

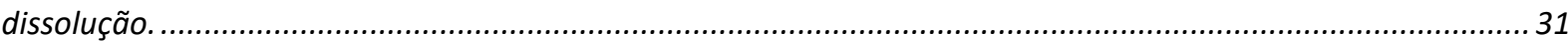

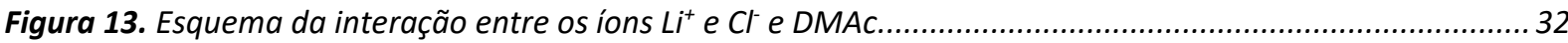

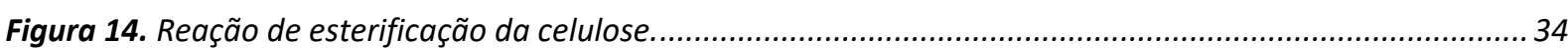

Figura 15. Representação esquemática dos tipos de uniformidade da derivatização da celulose. ...................... 35

Figura 16. Aparelho utilizado para técnica de eletrofiação (a) e esquema de funcionamento do equipamento

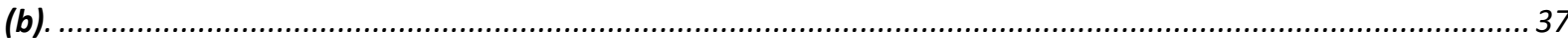

Figura 17. Efeito da variação de voltagem aplicada na formação do cone de Taylor. ....................................... 40

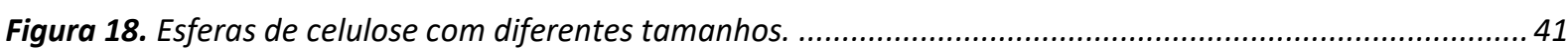

Figura 19. Micrografias de microesferas de celulose com diferentes porosidades:..........................................42

Figura 20. Estrutura 3D da lipase de Pseudomonas fluorescens $(a)$ e ........................................................44

Figura 21. Métodos de imobilização enzimática: adsorção, ligação covalente, ........................................... 45

Figura 22. Imobilização enzimática por (a) encapsulamento por meio da eletrofiação e ................................... 47

Figura 23. Diagrama de energia de uma reação catalisada por enzima. ..........................................................48

Figura 24. Resolução cinética enzimática de cloridrina (R,S 2-cloro-1-feniletan-1-ol)..................................... 49

Figura 25. Mecanismo de esterificação enantiosseletiva de álcool secundário quiral catalisada por enzima. ....50

Figura 26. Reação de complexação da celulose com CUEN (cuproetilenodiamina).......................................... 54

Figura 27. Padrão de difração de raios $X$ típico de fibras de algodão............................................................5

Figura 28. Representação das etapas do processo de dissolução da celulose. ................................................61

Figura 29. Representação das etapas do processo de derivatização da celulose. ............................................62

Figura 30. Representação vetorial do ângulo de contato como medida de ..................................................67

Figura 31. Resolução cinética enzimática de cloridrina (R,S 2-cloro-1-feniletan-1-ol)...................................... 70

Figura 32. Espectros na região do infravermelho para as amostras de celulose de linter e ............................... 72

Figura 33. Difratogramas de raios $X$ das amostras de celulose de linter e celulose de linter mercerizada.......... 75

Figura 34. (a) Modelo bidimensional da estrutura cristalina da celulose com respectivos planos cristalinos;..... 76 
Figura 35. Micrografias de (a), (b), (c) celulose de linter; (d), (e), (f) celulose de linter mercerizada.

Figura 36. Mapa de densidade de comprimento e espessura das amostras de celulose de linter e a celulose de linter mercerizada e gráfico da distribuição de comprimento e espessura das amostras de celulose de linter e celulose mercerizada.

Figura 37. Curvas TG/dTG da celulose de linter e da celulose de linter mercerizada......................................82

Figura 38. Mecanismo Broido-Shafizadeh de pirólise da celulose. .............................................................. 82

Figura 39. Reação de eliminação de água na celulose durante decomposição térmica....................................83

Figura 40. Espectros de absorção na região do infravermelho para hexanoatos de celulose, ............................87

Figura 41. Espectros de $R M N-{ }^{1} \mathrm{H}$ em DMSO-d6 para a amostra hexanoatos, benzoatos de celulose e ésteres mistos com diferentes graus médios de substituição. 90

Figura 42. Difratogramas de raios $X$ das amostras de hexanoatos de celulose e benzoatos de celulose. 92

Figura 43. Curvas TG/dTG dos hexanoatos e benzoatos de celulose com diferentes razões molares (fluxo de $\mathrm{N}_{2}$ de $20 \mathrm{~mL} \cdot \mathrm{min}^{-1}$, razão de aquecimento de $\left.20^{\circ} \mathrm{C} \cdot \mathrm{min}^{-1}\right)$.

Figura 44. Micrografias de Hex3 nas seguintes condições: (a) 9\%, $10 \mathrm{~cm}, 15 \mathrm{kV}$ e 5,5 $\mu \mathrm{m} . \mathrm{min}^{-1}$; 97

Figura 45. Micrografias de mats de Hex 6 (9\%) com $15 \mathrm{~cm}$ de distância, $15 \mathrm{kV}$ de tensão e fluxo de (a) 5,5 e (b)

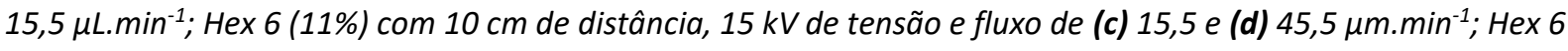
(11\%) com $10 \mathrm{~cm}$ de distância, 25 kV de tensão e fluxo de (e) 5,5, (f) 15,5 e (g) 45,5 $\mu \mathrm{m} . \mathrm{min}^{-1}$; Hex 6 (11\%) com $10 \mathrm{~cm}$ de distância, $20 \mathrm{kV}$ de tensão e fluxo de (h) 5,5, (i) 15,5 e (j) 45,5 $\mu \mathrm{m} . \mathrm{min}^{-1}$.

Figura 46. Micrografias de mats de Hex 6 (a) 11\% e (b) 13\% nas condições:. 100

Figura 47. Micrografias de mats de Hex 6 (11\%) nas seguintes condições: $10 \mathrm{~cm}$ de distância, 5,5 $\mu$ L.min ${ }^{-1}$,

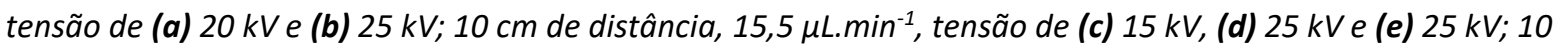
cm de distância, 45,5 $\mu$ L.min ${ }^{-1}$, tensão de (f) $15 \mathrm{kV}$, (g) $25 \mathrm{kV}$ e (h) $25 \mathrm{kV}$;

Figura 48. Micrografias de mats de Hex 12 (7\%) com (a) $5 \mathrm{~cm}$ de distância, $25 \mathrm{kV}$ de tensão e fluxo de 45,5 $\mu L$. $\min ^{-1}$ e (b) $10 \mathrm{~cm}$ de distância, $15 \mathrm{kV}$ de tensão e fluxo de 5,5 $\mu \mathrm{m} . \mathrm{min}^{-1}$. 101

Figura 49. Reação de esterificação do benzoato de celulose por ácido trifluoroacético. .................................102

Figura 50. Espectros na região do infravermelho para mats de benzoato de celulose e éster misto. 103

Figura 51. Micrografias e histogramas de distribuição de fibras de mantas de Benz 12 (9\% em TFA) com distância de $10 \mathrm{~cm}$ nas seguintes condições: (a) $20 \mathrm{kV}$ de tensão e 5,5 $\mu$ L. $\mathrm{min}^{-1}$ de vazão;. 104

Figura 52. Micrografias e histogramas de distribuição de fibras de ésteres mistos de celulose 9\% em TFA, com $10 \mathrm{~cm}$ de distância nas seguintes condições: (a) HexBenz $3 \mathrm{com} 20 \mathrm{kV}$ de tensão e 5,5 $\mu \mathrm{m} . \mathrm{min}^{-1}$; ..... 106

Figura 53. Imagens de ângulo de contato para (a) mat de Hex 6 (11\%) com $10 \mathrm{~cm}$ de distância entre agulhacoletor, 20 kV de tensão e 15,5 $\mu$ L. $\mathrm{min}^{-1}$; (b) mat de Benz $12 \mathrm{com} 10 \mathrm{~cm}$ de distância entre agulha-coletor, 20 kV de tensão e 15,5 $\mu$ L. min $^{-1}$. 108

Figura 54. Imagens de esferas Hex 6 (a) úmidos e (b) secos............................................................... 109

Figura 55. Micrografias da superfície de esferas e respectiva micrografia da rugosidade .............................. 111

Figura 56. Micrografias de esferas de e respectiva micrografia da rugosidade de .........................................112 
Figura 57. Fotografias de (a) mat de Hex 6 (11\%) e $100 \mathrm{mg}$ de lipase (30\%) nas condições: $10 \mathrm{~cm}$ de distância, $25 \mathrm{kV}$ de tensão e fluxo de 15,5 $\mu \mathrm{L} \cdot \mathrm{min}^{-1}$; (b) esferas de Hex 12 (15\% de lipase) em metanol; (c) esferas de Benz 12 (15\% de lipase) em água.

Figura 58. Micrografias de Hex 6 (11\%) com $10 \mathrm{~cm}$ de distância, tensão de $25 \mathrm{kV}$ e 15,5 $\mu \mathrm{m} . \mathrm{min}^{-1}$ nas seguintes condições: (a) Hex 6 (11\%); (b) Hex 6 (11\%) com Lipase (1,5\%); (c) Hex 6 (11\%) Lipase (3\%);.....

Figura 59. Micrografias de esferas de e respectiva micrografia da rugosidade de Benz 12 com 15\% de lipase em (a) água e (b) metanol; Hex 6 com 15\% de lipase em (c) água e (d) metanol. 116

Figura 60. Cromatogramas obtidos por GC-DIC para a cloridrina racêmica e do padrão de acetato racêmico. 117 Figura 61. Cromatogramas obtidos por CG-DIC da resolução cinética enzimática de cloridrina. 119 


\section{LISTA DE TABELAS}

Tabela 1. Condições experimentais utilizadas. 62

Tabela 2. Teor de $\alpha$-celulose, umidade, cinzas e porcentagem de nitrogênio (N) e enxofre (S) .73

Tabela 3. Grau de polimerização médio viscosimétrico e massa molar média viscosimétrica da 75

Tabela 4. Índice de cristalinidade (Ic) para celulose de linter e celulose de linter mercerizada. .77

Tabela 5. Relação entre tamanho médio do cristalito e planos cristalográficos. 78

Tabela 6. Resultados de decomposição térmica da celulose de linter e celulose de linter mercerizada obtidos por análise termogravimétrica. 84

Tabela 7. Porcentagem dos elementos carbono $(C)$, hidrogênio $(H)$ e nitrogênio $(N)$ nas amostras ................... 85

Tabela 8. Quantidade residual de lítio nas amostras de hexanoato e benzoato de celulose...............................8 86

Tabela 9. Possível atribuição de bandas observadas nos espectros IV de hexanoato de celulose, ........................88

Tabela 10. Grau médio de substituição dos ésteres de celulose. 91

Tabela 11. Índice de cristalinidade (Ic) para celulose de linter mercerizada e ésteres de celulose. 93

Tabela 12. Resultados de decomposição térmica dos ésteres de celulose obtidos por análise termogravimétrica.

Tabela 13. Ângulo de avanço, recuo e histerese para mats de ésteres de celulose. 107

Tabela 14. Diâmetro médio e rugosidade média das esferas de ésteres de celulose. 110

Tabela 15. Resolução cinética de cloridrina (R,S 2-cloro-1-feniletan-1-ol) utilizando lipase imobilizada em esferas de éster de celulose com valores de excesso enantiomérico de substrato (ees), excesso enantiomérico de produto $\left(e e_{p}\right)$, conversão (c) e razão enantiomérica $(E)$, sendo indicado o não-solvente usado na formação das esferas (água ou metanol). 


\section{LISTA DE ABRAVIATURAS E SIGLAS}

\%c percentual de conversão dos reagentes em produtos

ABRAPA Associação Brasileira dos Produtores de Algodão

ASTM American Society for Testing and Materials

Benz Benzoato de celulose

CEP Campo elétrico pulsado

CG-DIC Cromatógrafo a gás acoplado a um detector de ionização de chama

CUEN Cuproetilenodiamina

DMAc N,N-dimetilacetamida

DMSO Dimetilsulfóxido

dTG Derivada primeira da curva termogravimétrica

E Razão enantiomérica

ee Excesso enantiomérico

$e e_{p} \quad$ Excesso enantiomérico do produto

$e e_{s} \quad$ Excesso enantiomérico do substrato

FTIR Espectroscopia na região do infravermelho

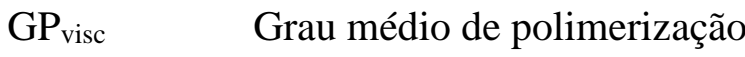

GS Grau médio de substituição

Hex Hexanoato de celulose

HexBenz Hexanoato-benzoato de celulose

Ic Índice de Cristalinidade

$\mathrm{LiCl} \quad$ Cloreto de lítio

LPF Lipase de Pseudomonas fluorescens

MM Massa molar

MEV Microscopia Eletrônica de Varredura

$\mathrm{MM}_{\mathrm{visc}} \quad$ Massa molar viscosimétrica

$\mathrm{NaOH} \quad$ Hidróxido de sódio

ppb Parte por bilhão

RCE Resolução Cinética Enzimática

RMN- ${ }^{1} \mathrm{H} \quad$ Ressonância Magnética Nuclear de Prótons

TAPPI Technical Association of the Pulp and Paper Industry

TFA Ácido trifluoroacético 
Análise termogravimétrica

THF

Tetraidrofurano

UAG

Unidade anidroglicosídica 


\section{SUMÁRIO}

1 INTRODUÇÃO

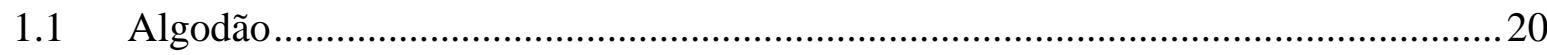

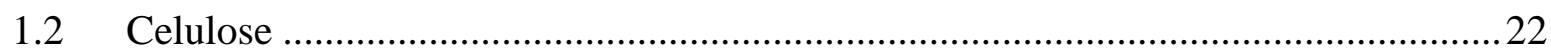

1.2.1 Estruturas Polimórficas das Celulose …………………………………....2

1.3 Pré-Tratamento Alcalino (Mercerização) ………………………………………........27

1.4 Solubilização da Celulose em Cloreto de lítio/Dimetilacetamida ...............................31

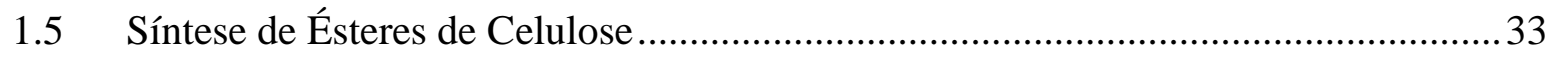

1.6 Eletrofiação: Preparação de Mantas .............................................................................36

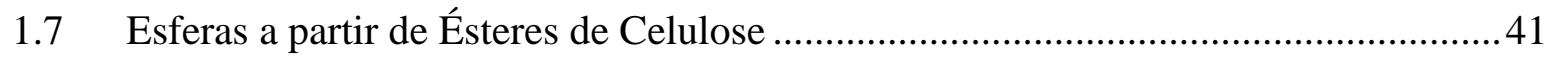

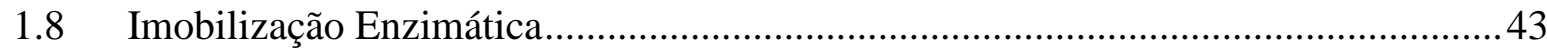

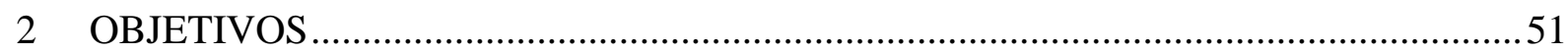

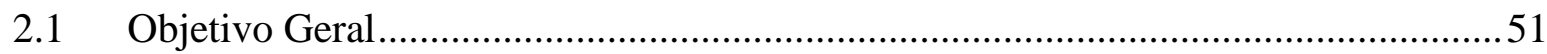

2.2 Objetivos Específicos ………………………………………………………...51

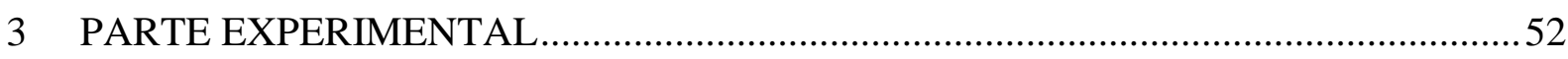

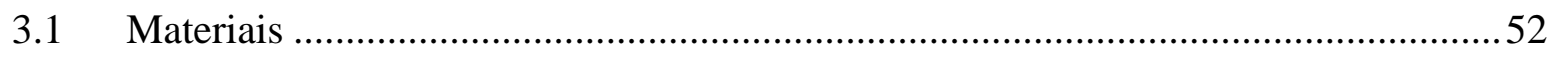

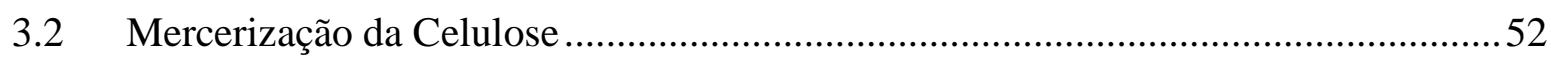

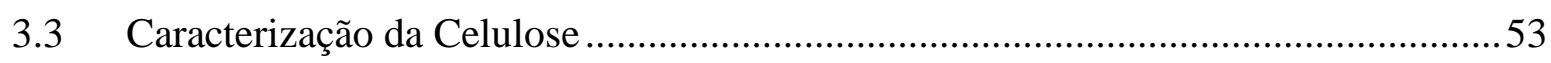

3.3.1 Espectroscopia na Região do Infravermelho ……………………………....53

3.3.2 Grau Médio de Polimerização ......................................................................53

3.3.3 Teor de $\alpha$-Celulose ..............................................................................56

3.3.4 Teor de Umidade ..................................................................................

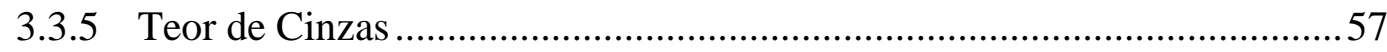

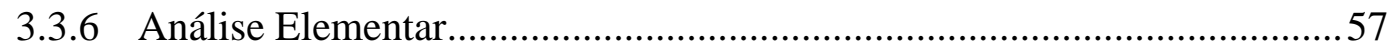

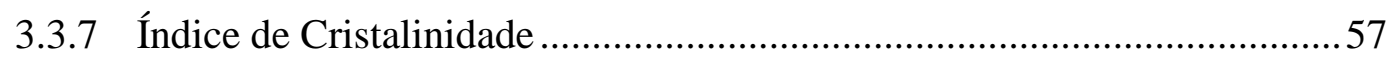

3.3.8 Microscopia Eletrônica de Varredura...........................................................59 
3.3.9 Comprimento e Espessura Médios 60

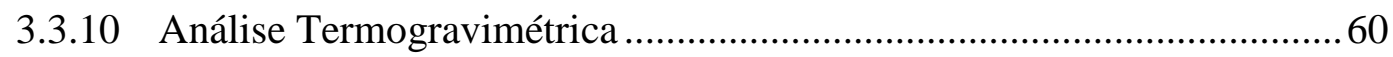

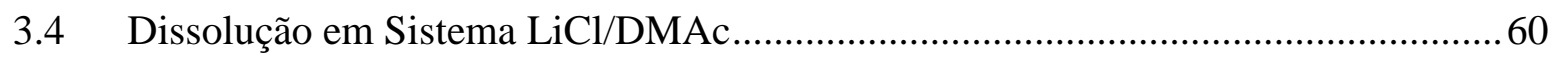

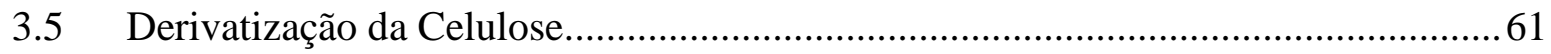

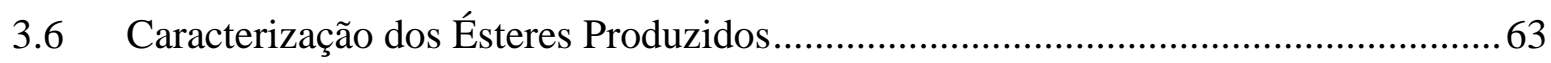

3.6.1 Espectroscopia na Região do Infravermelho ........................................63

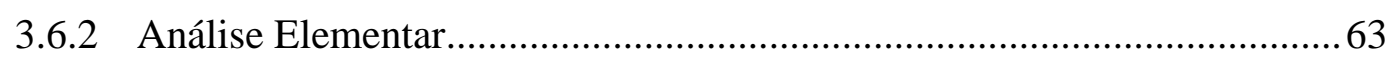

3.6.3 Espectroscopia de Absorção Atômica (Lítio).........................................6 63

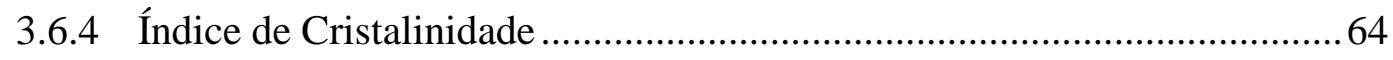

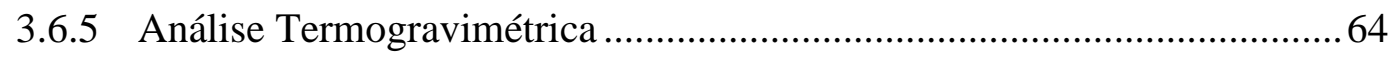

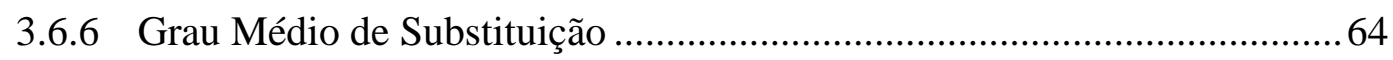

3.6.6.1 Espectroscopia de Ressonância Magnética Nuclear ..........................6 64

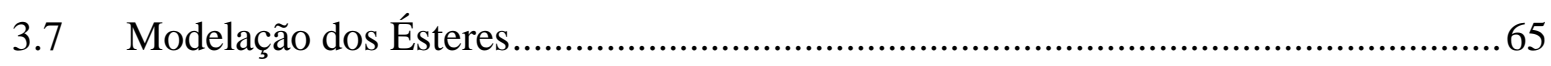

3.7.1 Preparação de Mantas Não Tecidas via Eletrofiação ..............................66

3.7.1.1 Caracterização das Mantas .............................................................. 66

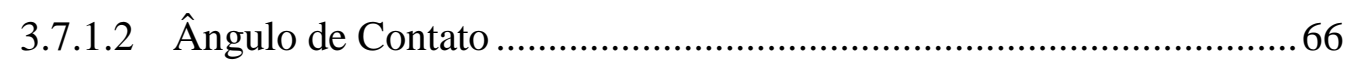

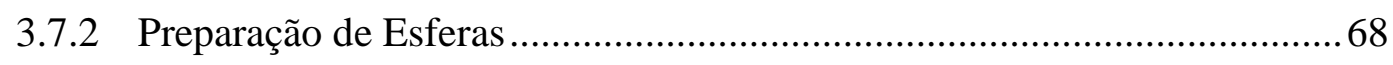

3.7.2.1 Caracterização das Esferas.......................................................... 68

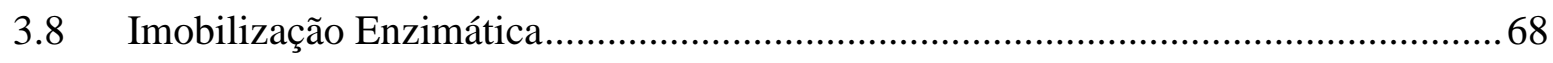

3.8.1 Imobilização de Lipases em Mantas.................................................... 68

3.8.2 Imobilização de Lipases em Esferas....................................................69

3.9 Biocatálise na Reação de Resolução Cinética de Cloridrina Racêmica ....................69

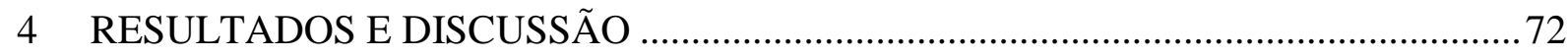

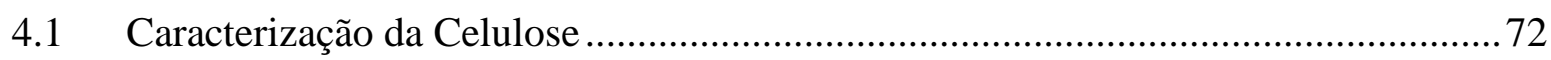

4.1.1 Espectroscopia na Região do Infravermelho ....................................... 72

4.1.2 Teor de $\alpha$-celulose, Umidade, Cinzas e Análise Elementar ..................... 73

4.1.3 Grau de Polimerização Médio Viscosimétrico ....................................... 74 


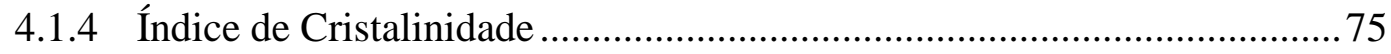

4.1.5 Microscopia Eletrônica de Varredura..................................................... 78

4.1.6 Avaliação do Comprimento e Espessura Médios das Fibras...................... 80

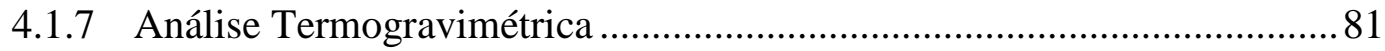

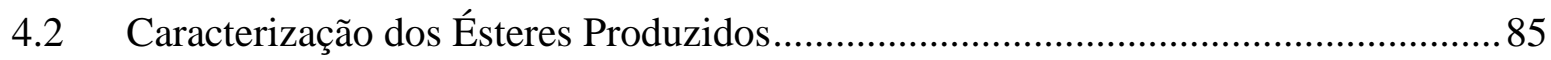

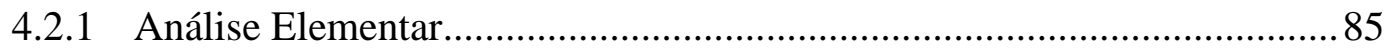

4.2.2 Espectroscopia de Absorção Atômica (Lítio).......................................... 85

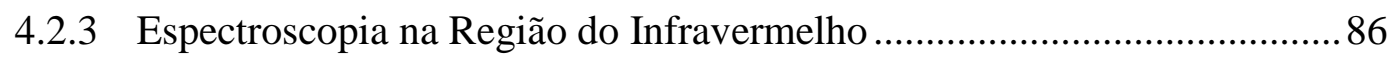

4.2.4 Determinação do Grau Médio de Substituição........................................ 89

4.2.4.1 Espectroscopia de Ressonância Magnética Nuclear $\left({ }^{1} \mathrm{H}\right)$................. 89

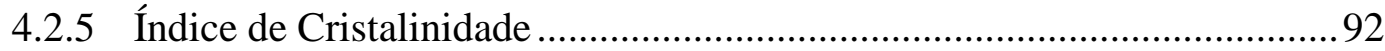

4.2.6 Análise Termogravimétrica ...............................................................93

4.3 Preparação de Mantas via Eletrofiação..................................................................... 96

4.3.1 Mantas obtidas a partir de Soluções de Tetraidrofurano/Dimetilacetamida 96

4.3.2 Mantas produzidas a partir de Soluções de Ácido Trifluoroacético.........102

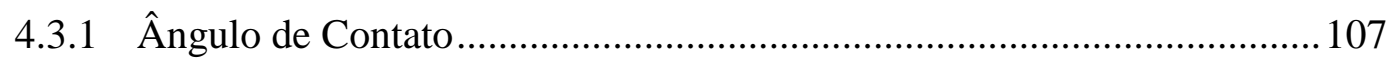

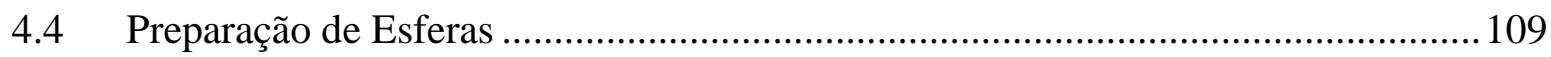

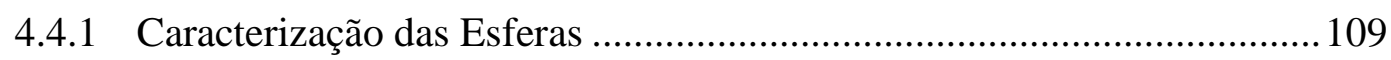

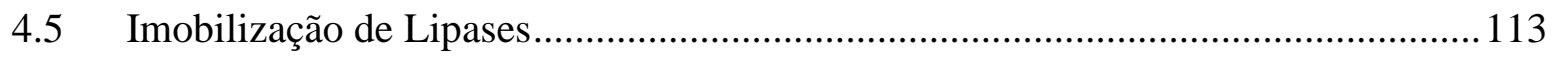

4.6 Aplicação na Resolução Cinética de Cloridrina Racêmica..................................... 117

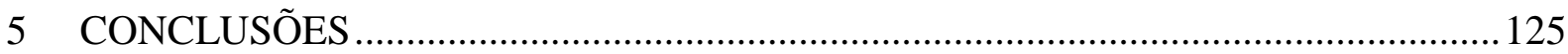

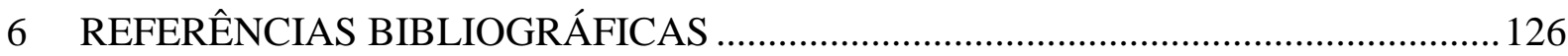




\section{INTRODUÇÃO}

Pesquisas têm sido desenvolvidas visando reduzir a dependência de matérias-primas procedentes de fontes fósseis, buscando materiais sustentáveis originados de fontes renováveis (RODRIGUES et al., 2015; BHATIA et al., 2019; GUMINA et al., 2019). Neste sentido, as matérias-primas oriundas de biomassa têm atraído muito interesse, e a viabilidade de seu uso tem sido confirmada em inúmeros estudos reportados na literatura (STEINBACH; WINKENBACH; EHMSEN, 2011; LOMELÍ-RAMÍREZ et al., 2018; DU et al., 2019).

As fibras celulósicas provenientes da biomassa têm grande potencial como matériaprima para novos materiais devido às suas propriedades como biodegradabilidade, ampla disponibilidade, reciclabilidade, não-toxicidade, baixa densidade e baixo custo (TINGAUT; ZIMMERMANN; LOPEZ-SUEVOS, 2010; LIU et al., 2014; THAKUR; THAKUR, 2014). Além disso, a derivatização da celulose produz materiais que podem ser processados no estado fundido, ou podem ser solubilizados mais facilmente comparados à celulose nativa (MARK et al., 1988). Pesquisas têm sido dedicadas à busca de tecnologias de processamento eficientes para conversão dessa biomassa em produtos bio-baseados de alto valor agregado (DAI et al., 2019; FU et al., 2019).

Neste sentido, o presente estudo tem como objetivo a valorização da celulose extraída de fibras provenientes do linter de algodão, mediante seu uso como matériaprima para a preparação de novos materiais.

\subsection{Algodão}

A palavra "algodão" tem origem árabe, derivada da palavra قطن (qutn ou qutun). O algodoeiro pertence ao gênero botânico Gossypium, à tribo Gossypieae e à família Malvaceae (WENDEL; GROVER, 2015). Geralmente é cultivado em regiões tropicais e subtropicais, chegando a atingir o tamanho de uma planta de pequeno porte.

Existem três produtos principais derivados da produção de algodão: algodão em pluma, fibras de linter e sementes de algodão (Figura 1). As fibras da pluma do algodão, também denominadas lint, são longas (> $25 \mathrm{~mm}$ ) podendo ser fiadas e utilizadas em confecções têxteis. As fibras do linter podem ser facilmente separadas das sementes através do processo de descaroçamento. Linters são fibras mais curtas do que as plumas do algodão (geralmente <15 $\mathrm{mm}$ ) e ainda estão aderidas às sementes após o processo de descaroçamento (MORAIS et al., 
2013). Estes são retirados da semente por uma segunda ou terceira operação de descaroçamento. Os linters não são utilizados na indústria têxtil, sendo, portanto, destinados a fabricação de plásticos, produtos de papel, filmes e cosméticos. O caroço de algodão é triturado e convertido em óleo e cascos (revestimento exterior da semente). O óleo purificado é usado na culinária, sendo o subproduto mais valioso da semente de algodão. Os cascos são usados na alimentação pecuária, fertilizantes, combustível e materiais de embalagem (FANG, 2018).

Figura 1. Planta de algodão e sua composição.

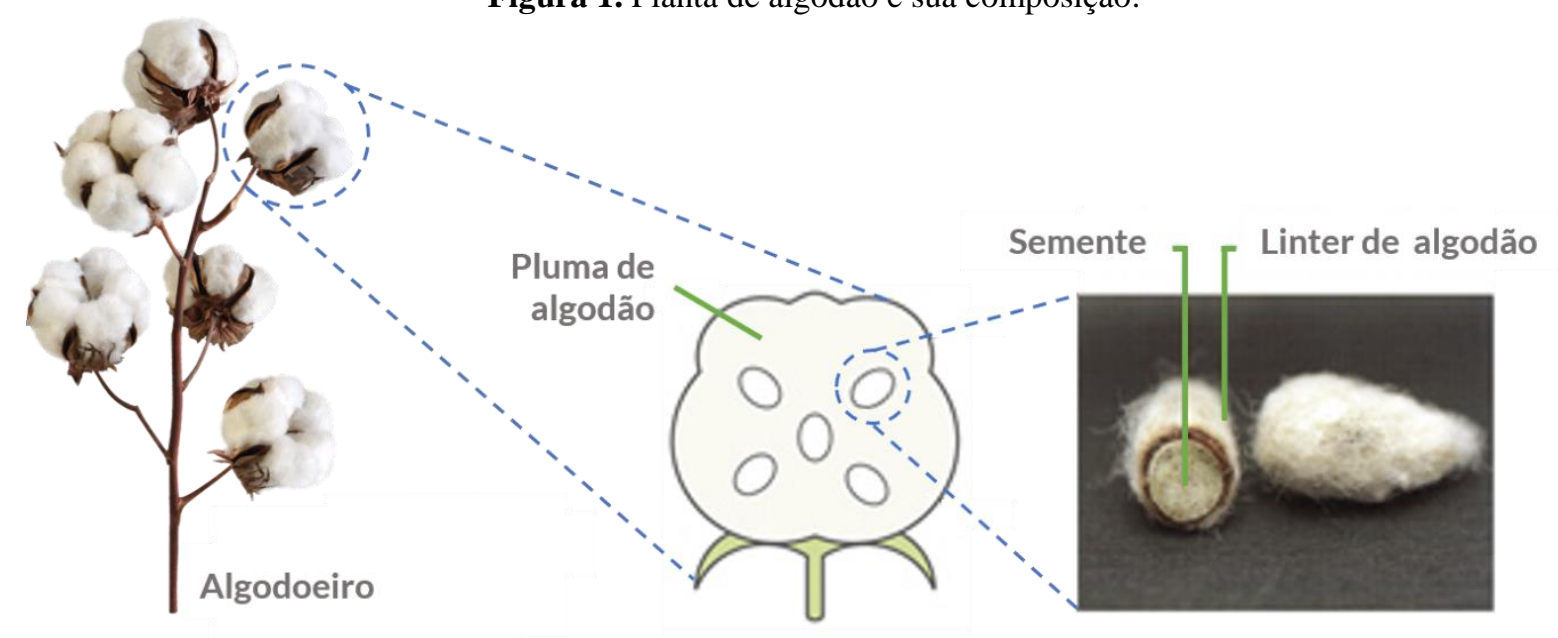

Fonte: adaptado ASAHI KASEI CORPORATION, 2019.

As fibras provenientes do linter do algodão são constituídas predominantemente de celulose (88-97\%), tendo ainda, em pequenas quantidades, pectinas $(0,4-1,2 \%)$, constituintes minerais (0,7-1,6\%), lipídeos (óleos e ceras) e resinas (0,4-1,2\%) (GORDON; HSIEH, 2007; ZUGENMAIER, 2008; MORGADO, 2009; MORAIS et al., 2013; HEINZE; EL SEOUD; KOSCHELLA, 2018).

A celulose de algodão apresenta grande potencial para aplicação em novos materiais por ter alto teor de celulose e curto ciclo de crescimento (de 130 a 220 dias), além da grande disponibilidade. O Brasil é o segundo maior exportador mundial de algodão atrás apenas dos Estados Unidos. A produção nacional de algodão em 2018/19 apresentou crescimento de $35,9 \%$ correspondendo a 2,7 milhões de toneladas e a produção de algodão caroço em 2018/19 foi 3,7 milhões de toneladas (ABRAPA - Associação Brasileira dos Produtores de Algodão).

No presente estudo, a celulose extraída linter de algodão foi utilizada como matéria-prima para a preparação de novos materiais. 


\subsection{Celulose}

A celulose é o principal componente da biomassa vegetal, sendo considerada o homopolímero orgânico vegetal mais abundante na Terra (SANTMARTÍ; LEE, 2018). No entanto, foi somente em 1838 que Anselme Payen isolou os componentes de diferentes materiais à base de plantas e obteve uma substância representada pela fórmula química $\left(\mathrm{C}_{6} \mathrm{H}_{10} \mathrm{O}_{5}\right)_{\mathrm{n}}$ que ele denominou celulose (do latim cellula, diminutivo de cella, + ose) (PAYEN, 1838). A celulose é um homopolissacarídeo linear formado por unidades do monossacarídeo $\beta$ D-glicopiranose unidas por ligações glicosídicas do tipo $\beta$ - $(1 \rightarrow 4)$ deslocada $180^{\circ}$ com relação a seus vizinhos (AZIZI SAMIR; ALLOIN; DUFRESNE, 2005; HABIBI; LUCIA; ROJAS, 2010). O segmento de repetição é considerado um dímero de glicose denominado celobiose e cada celobiose é composta por duas unidades repetitivas chamadas unidades anidroglicosídicas (UAG) (Figura 2) (MOON et al., 2011).

Figura 2. Estrutura da unidade repetitiva da celulose.

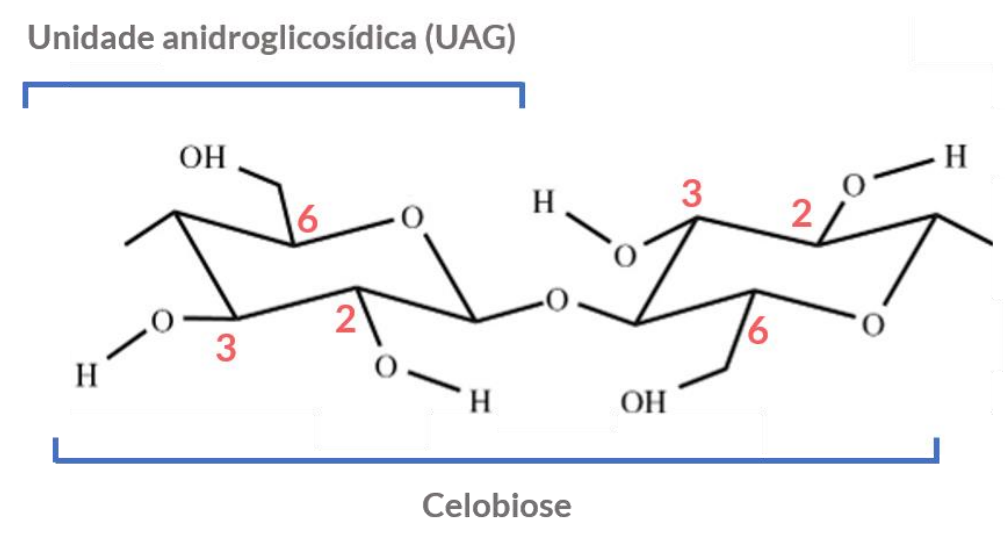

Fonte: adaptado CHEN et al., 2018.

A estrutura molecular da celulose aparenta ser simples, mas a estrutura supramolecular faz da celulose uma macromolécula extremamente complexa.

Cada unidade anidroglicosídica da celulose possui três grupos hidroxilas diferentes: $\mathrm{OH}_{(2)}$ e $\mathrm{OH}_{(3)}$ (álcoois secundários), e $\mathrm{OH}_{(6)}$ (álcool primário) que são os principais grupos reativos suscetíveis à modificação química. Dentre as três hidroxilas, aquela ligada ao carbono primário $\left(\mathrm{OH}_{(6)}\right)$ seria a mais reativa, por estar menos impedida estericamente na UAG (ASS; CIACCO; FROLLINI, 2006). A ordem de reatividade das hidroxilas é normalmente $\mathrm{OH}_{(6)}$ >> $\mathrm{OH}_{(2)}>\mathrm{OH}_{(3)}$. A menor reatividade de $\mathrm{OH}_{(3)}$ quando comparada a $\mathrm{OH}_{(2)}$ pode ser relacionada ao fato de o grupo hidroxila estar envolvido em ligações hidrogênio intramoleculares (Figura 
3) que são mais difíceis de serem rompidas (ASS; BELGAGEM; FROLLINI, 2006). Embora esta ordem de reatividade seja confirmada para muitos derivados de celulose, exceções já foram relatadas (DAWSEY; MCMORMICK, 1990; SAMARANAYAKE; GLASSER, 1993).

Os grupos hidroxila são capazes de interagir uns com os outros, formando ligações hidrogênio de dois tipos: intramoleculares, que contribuem para a rigidez das cadeias, e intermoleculares, que contribuem para a formação da estrutura supramolecular (Figura 3) (FENFEL; WEGENER, 1989; MORGENSTERN; KAMMER, 1996). As ligações intermoleculares são responsáveis pela formação de domínios cristalinos, microfibrilas e fibrilas, as quais formam fibras de celulose.

Figura 3. Representações das ligações hidrogênio intra e intermoleculares da celulose.

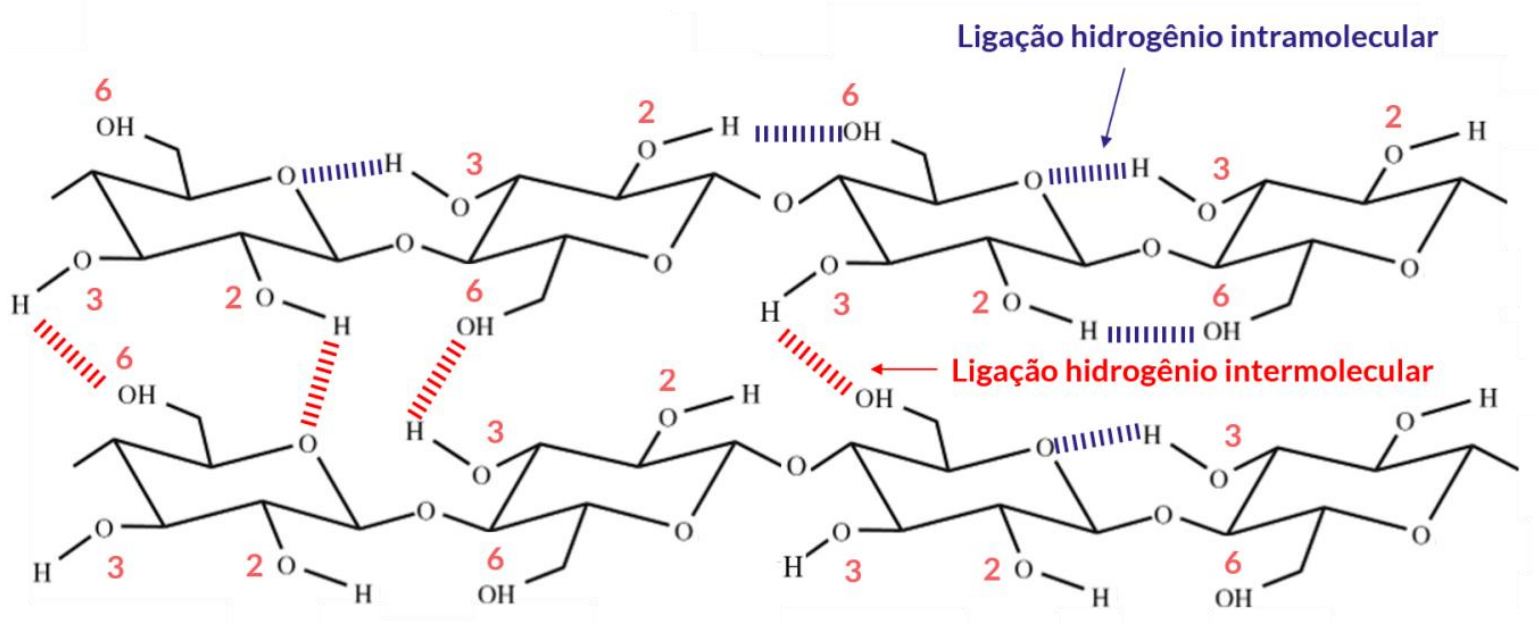

Fonte: adaptado CHEN et al., 2018.

Devido a sua conformação, os grupos hidroxilas ficam dispostos em posições equatoriais e os átomos de hidrogênio ocupam as posições axiais sendo possível a formação de ligações hidrogênio entre hidrogênios e oxigênios adjacentes linearizando a cadeia.

A rede de ligações hidrogênio inter e intramoleculares na celulose é forte devido à estrutura da cadeia e aos abundantes grupos hidroxila. Portanto, a celulose não é facilmente dissolvida em água, soluções aquosas ou solventes orgânicos comuns devido as suas propriedades anfifílicas (Figura 4), isto é, grandes quantidades de ligações hidrogênio hidrofílicas em combinação com interações hidrofóbicas, o que limita o processamento, e por consequência, a utilização da celulose (MEDRONHO; ROMANO; GRAC, 2012). O caráter anfifílico da celulose pode ser derivado de segmentos hidrofóbicos e hidrofílicos da estrutura. O caráter hidrofílico é apresentado na direção equatorial de uma UAG, pelo fato de todos os três grupos hidroxila estarem localizados nas posições equatoriais do anel. Por outro lado, o caráter hidrofóbico é encontrado na direção axial da UAG pois as ligações $\mathrm{C}-\mathrm{H}$ estão 
localizadas nas posições axiais do anel (BERGENSTRÅHLE et al., 2010; MEDRONHO; LINDMAN, 2014a). A questão-chave para o sucesso da dissolução da celulose é decompor a robusta rede de ligações hidrogênio e, a partir disto, estabilizar as cadeias de celulose na solução.

Figura 4. Partes hidrofílicas e hidrofóbicas da molécula de celulose.

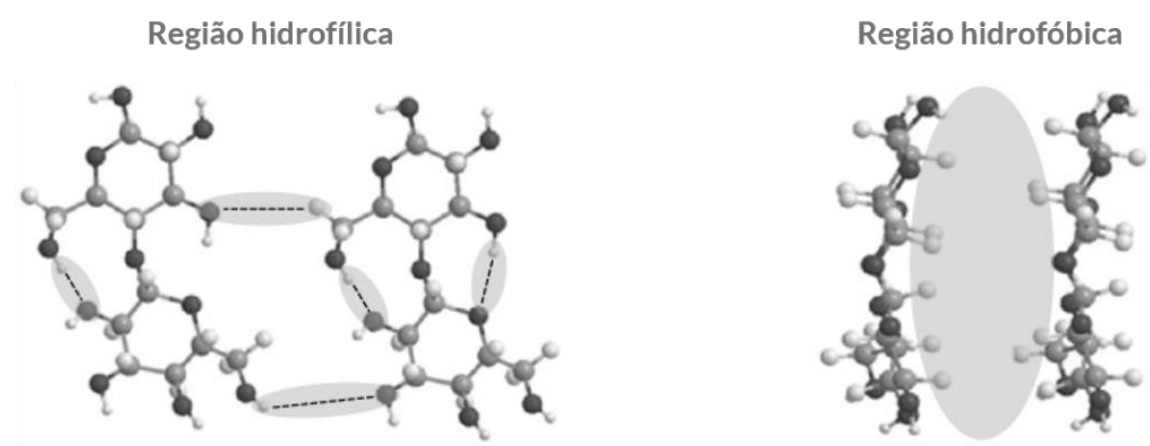

Fonte: adaptado MEDRONHO; LINDMAN, $2014 \mathrm{~b}$.

As cadeias de celulose possuem uma forte tendência para se agregarem em entidades estruturais altamente ordenadas devido a sua composição e sua conformação espacial. Aproximadamente 36 cadeias de celulose se alinham (agregam) por meio das ligações hidrogênio intermoleculares para formar fibrilas elementares com diâmetro de cerca de 3-4 nm (FANG, 2018). Estas fibrilas elementares se associam dando origem a microfibrilas com diâmetro variado de 10 a 30 nm (LEE; EVANS; WOODWARD, 2000). Estas microfibrilas têm domínios ordenados (regiões cristalinas) e domínio desordenados (regiões não cristalinas) (Figura 5). Estas regiões não possuem fronteiras bem definidas e a razão entre as mesmas pode variar, de acordo com a origem da celulose (ALMEIDA, 2009). As microfibrilas de celulose, por sua vez, são alinhadas e unidas em agregados de fibrilas ou macrofibrilas, com diâmetros que variam de 60 a $360 \mathrm{~nm}$, por uma matriz de pectina ou lignina (GIBSON, 2012). As fibrilas, por sua vez, se ordenam para formar as sucessivas paredes celulares da célula vegetal (MORGADO, 2009). 
Figura 5. Regiões cristalinas e não cristalinas em estrutura de microfibrila de celulose.

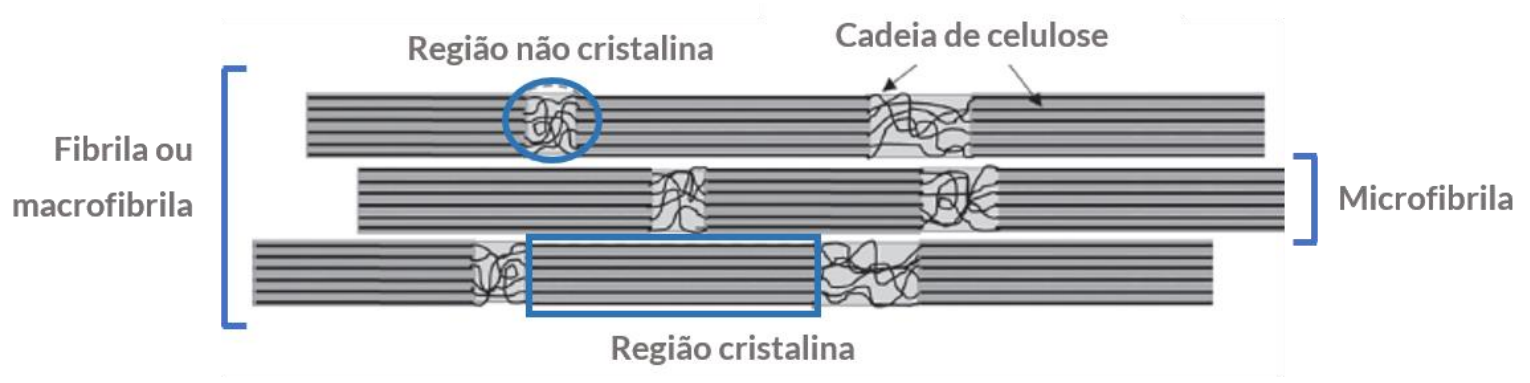

Fonte: adaptado SANTMARTÍ; LEE, 2018

Por se tratar de material natural abundante, a celulose tornou-se um assunto em pauta na ciência, tão logo ferramentas apropriadas para investigações científicas tornaram-se disponíveis para melhorar as propriedades dos materiais. Portanto, a celulose tem sido considerada como um dos mais importantes objetos de estudo na história da ciência dos polímeros (ZUGENMAIER, 2008). Cabe mencionar que a celulose foi responsável pelo início da indústria de polímeros. O primeiro polímero não natural desenvolvido foi o nitrato de celulose (1838), seguido do acetato de celulose (1865), sendo estes polímeros descobertos bem antes dos polímeros provenientes de fontes fósseis (GANDINI, 2011).

\subsubsection{Estruturas Polimórficas das Celulose}

A celulose apresenta uma complexa rede de ligações hidrogênio intra e intermoleculares. As diferentes configurações das ligações hidrogênio alteram o empacotamento e a orientação molecular das cadeias de celulose, levando à formação de diferentes estruturas cristalinas ou polimórficas. Assim, a celulose apresenta seis diferentes estruturas polimórficas (I, II, IIII, III II, IV I e IV II $_{\text {II }}$, dependendo da fonte de celulose, método de extração de celulose e tratamentos (Figura 6) (O'SULLIVAN, 1997; HABIBI; LUCIA; ROJAS, 2010; MOON et al., 2011). Cada polimorfo tem diferentes parâmetros de rede celular unitária e diferentes configurações de empacotamento da cadeia de celulose.

A celulose I $\alpha$ é a estrutura dominante na celulose proveniente de algas e bactérias (MIHRANYAN, 2011) e a celulose I $\beta$ é o subpolimorfo dominante na celulose obtida da parede celular de plantas (WADA; OKANO; SUGIYAMA, 2001). A estrutura de celulose I $\alpha$ contém uma cadeia de celulose em uma célula unitária triclínica (parâmetros de cela: $\mathrm{a}=6,717 \AA$, $\mathrm{b}=$ $5,962 \AA, c=10,40 \AA, \alpha=118,1^{\circ}, \beta=114,8^{\circ} \mathrm{e} \gamma=80,37^{\circ}$ ), enquanto a célula unitária de celulose 
I $\beta$ contém duas cadeias e tem uma estrutura monoclínica (parâmetros de cela: $a=7,784 \AA$, $b=$ $8,201 \AA, c=10,38 \AA, \alpha=\beta=90^{\circ}$ e $\left.\gamma=96,5^{\circ}\right)$.

Figura 6. Interconversão dos polimorfos da celulose.

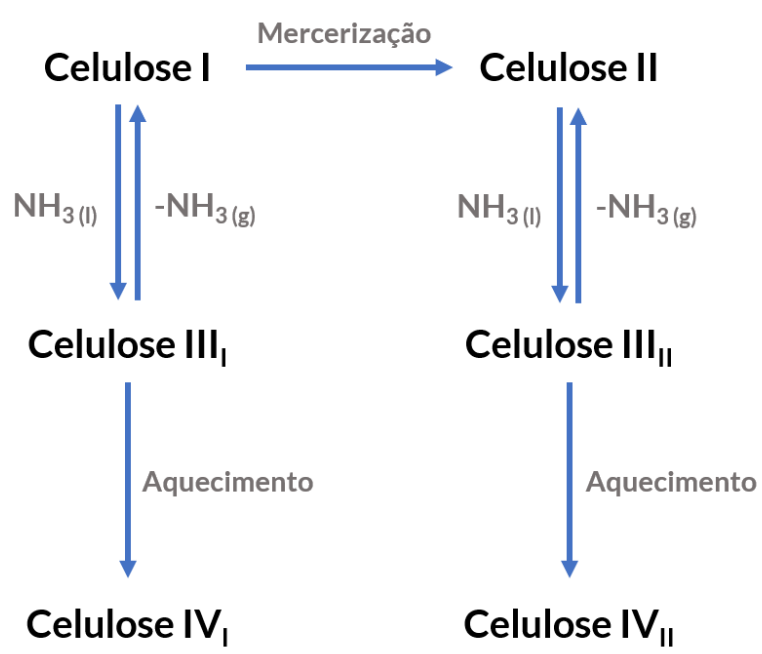

Fonte: adaptado O’SULLIVAN, 1997.

A celulose I pode ser convertida em celulose II por meio de mercerização. A mercerização é o nome dado à conversão realizada pelo inchamento de fibras celulósicas nativas em solução concentrada de hidróxido de sódio (KOLPAK; WEIH; BLACKWELL, 1978). A celulose mercerizada é termodinamicamente mais estável que a celulose I e pode ser produzida a partir da celulose I mas o inverso não ocorre (SANTMARTÍ; LEE, 2018). A estabilidade da celulose II resulta do arranjo antiparalelo das cadeias de celulose que estão dispostas em uma rede 3D de ligações hidrogênio intra e intermoleculares, enquanto a celulose I tem arranjo paralelo das cadeias originando uma estrutura 2D formada por camadas (planos) unidas por ligações hidrogênio intramoleculares (intraplanares) uma sobre a outra sendo a interação entre essas camadas do tipo van der Waals (interplanar).

A estrutura cristalina da celulose pode ser modificada em celulose III quando tratada com produtos químicos contendo grupos amina, como amônia ou etilenodiamina. A celulose

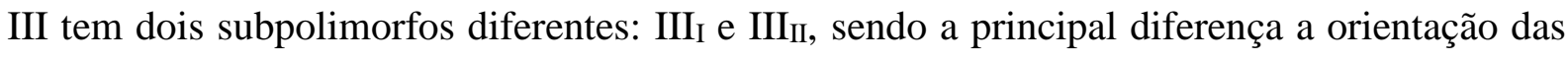
cadeias de celulose. O tipo de subpolimorfo obtido depende da estrutura cristalina inicial da fonte de celulose. Se a celulose tratada com aminas corresponder a celulose natural (celulose

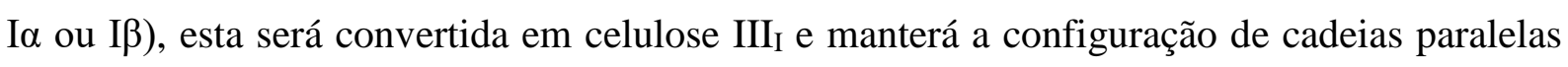
(WADA et al., 2004). Caso a celulose II seja tratada com aminas, ela será convertida em IIIII e as cadeias de celulose terão um empacotamento antiparalelo (WADA et al., 2009). 
Se a celulose III (III e IIIII $_{\text {II }}$ for aquecida em água, glicerol ou formamida a temperaturas de até $180^{\circ} \mathrm{C}$, a estrutura cristalina será convertida em celulose IV (ZERONIAN; RYU, 1987). A celulose IV também exibe dois subpolimorfos ( $I_{\mathrm{I}}$ e $\left.\mathrm{IV}_{\mathrm{II}}\right)$ e sua formação também depende da fonte de celulose. Se a celulose $\mathrm{III}_{\mathrm{I}}$ for aquecida, a estrutura cristalina

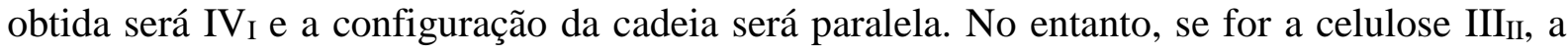
estrutura cristalina final será celulose IV $_{\text {II }}$ com um empacotamento de cadeias antiparalelo (GARDINER; SARKO, 1985).

Neste estudo, as fibras de celulose foram submetidas a pré-tratamentos tal como a mercerização (tratamento com solução aquosa de $\mathrm{NaOH}$ ), visando aumentar a solubilidade e/ou reatividade da celulose (HEINZE; EL SEOUD; KOSCHELLA, 2018; KASCHUK; FROLLINI, 2018).

\subsection{Pré-Tratamento Alcalino (Mercerização)}

O processo de mercerização envolve o tratamento de fibras de celulose com solução de hidróxido de sódio, de concentração no intervalo de 12 a 20\% (CIACCO et al., 2008). John Mercer, na primeira metade do século XIX, observou que quando o algodão era imerso em uma solução de soda cáustica concentrada, este diminuía em largura e comprimento tornando-se mais denso (CARR, 1995). Também observou que o algodão ficou mais resistente e sua afinidade com corantes melhorou (WOODINGS, 2001).

Na mercerização, a celulose é suspensa em uma solução aquosa de hidróxido de sódio concentrada, seguida de lavagem com água a fim de remover o $\mathrm{NaOH}$ e por fim secagem da celulose (Figura 7). Esse tratamento leva ao intumescimento intercristalino e intracristalino, o que interfere nas ligações hidrogênio intermoleculares (NEVELL; ZERONIAN, 1985).

Figura 7. Mecanismo do rearranjo das cadeias celulose em mercerização.

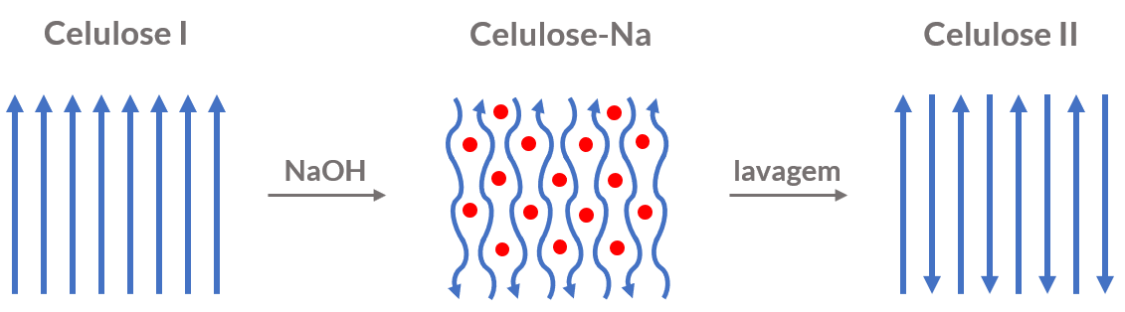

Fonte: adaptado SHIBAZAKI; KUGA; OKANO, 1997. 
No intumescimento intercristalino, que é o caso do intumescimento com a água, a água penetra apenas nos interstícios entre as unidades das estruturas fibrilares e intumesce as áreas menos ordenadas, causando o inchamento das fibrilas da celulose (Figura 8) (LACERDA, 2012).

Figura 8. Mecanismo de intumescimento da celulose com água.

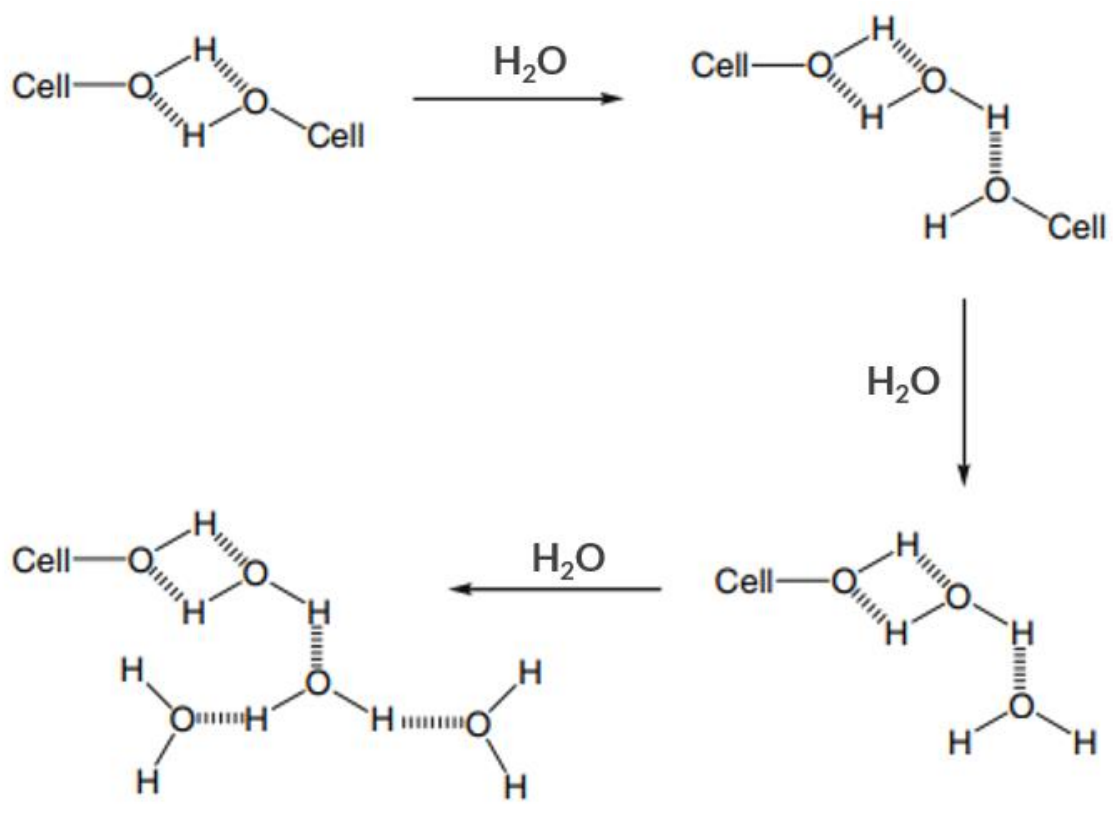

Fonte: EL SEOUD et al., 2008.

No intumescimento intracristalino, o agente intumescedor entra nos interstícios fibrilares penetrando nas regiões não cristalinas e cristalinas (NEVELL e ZERONIAN, 1985). Os grupos hidroxila da celulose interagem fisicamente com $\mathrm{NaOH}$ em altas concentrações intumescendo à medida que os cátions $\mathrm{Na}^{+}$penetram nos espaços intracristalinos da celulose (Figura 9). Como resultado, ocorre a conversão cristalográfica da celulose I (celulose nativa) para celulose II facilitando a posterior solubilização da mesma (YOUNESI; WU; AKKUS, 2019). Esse intumescimento também pode romper as agregações de fibrilas que ocorrem naturalmente, aumentando assim a reatividade da celulose. 
Figura 9. Interação entre celulose e íons $\mathrm{Na}^{+}$.

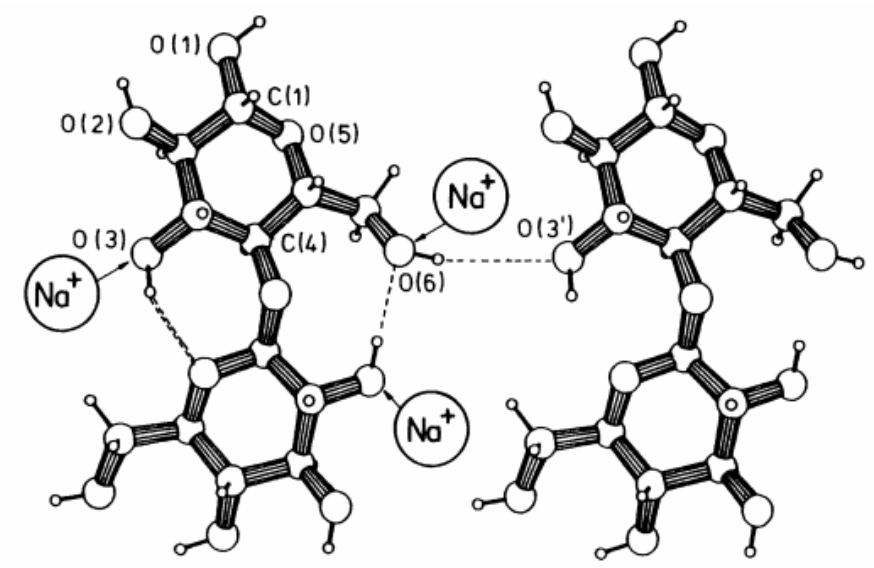

Fonte: FINK et al., 1995.

A conversão cristalográfica ocorre devido ao fato de o grupo hidroximetila $\left(-\mathrm{CH}_{2} \mathrm{OH}\right)$ poder assumir diferentes conformações, que geram duas diferentes estruturas de empacotamento das cadeias de celulose. A estrutura de cadeias paralelas, característica da celulose $\mathrm{I}$, ocorre quando os grupos $-\mathrm{CH}_{2} \mathrm{OH}$ de cadeias adjacentes se encontram na mesma conformação. Desse modo, as cadeias dispostas paralelamente favorecem as interações hidrofóbicas. A estrutura antiparalela, característica da celulose II, ocorre quando cadeias adjacentes possuem os grupos $-\mathrm{CH}_{2} \mathrm{OH}$ em diferentes posições sendo esta mudança irreversível (LANGAN; NISHIYAMA; CHANZY, 2001). Dessa forma, há formação de ligações hidrogênio em maior extensão e ordenação gerando arranjos em escala tridimensional (Figura 10). Isto também resulta numa estrutura mais estável termodinamicamente, o que explica porque a celulose II não pode ser revertida a celulose I, menos estável (KROONBATENBURG; KROON, 1997; ZHAO et al., 2006).

Figura 10. Projeção da cela unitária da celulose I e celulose II.
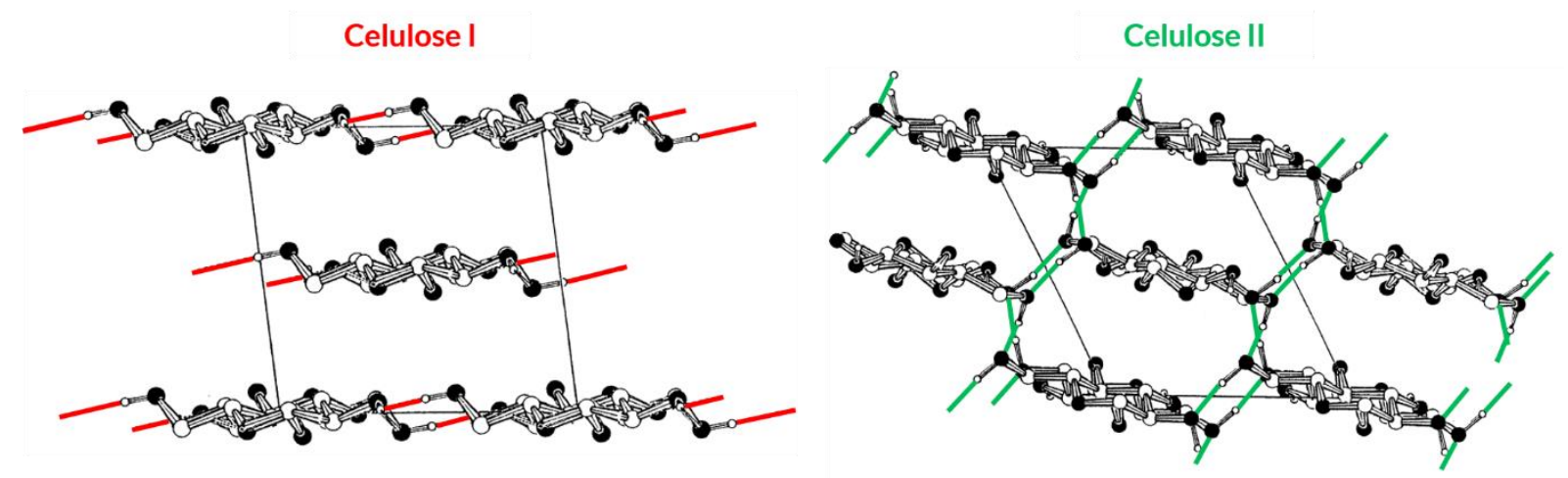

Fonte: NORTHOLT et al., 2001. 
A principal diferença entre as estruturas de celulose tipo I e II é com relação às posições das ligações hidrogênio intermoleculares das moléculas de celulose adjacentes. A celulose I apresenta predominantemente as ligações hidrogênio em relação à posição $\mathrm{OH}_{(6)}-\mathrm{O}_{(3)}$ como resultado de uma conformação trans-gauche (tg) e na celulose II o conjunto dominante se refere a posição $\mathrm{OH}_{(6)}-\mathrm{O}_{(2)}$ devido a conformação gauche-trans (gt) (HORII; HIRAI; KITAMARU, 1983; HISHIKAWA; TOGAWA; KONDO, 2017) (Figura 11).

Figura 11. Ligações hidrogênio da celulose I e celulose II.
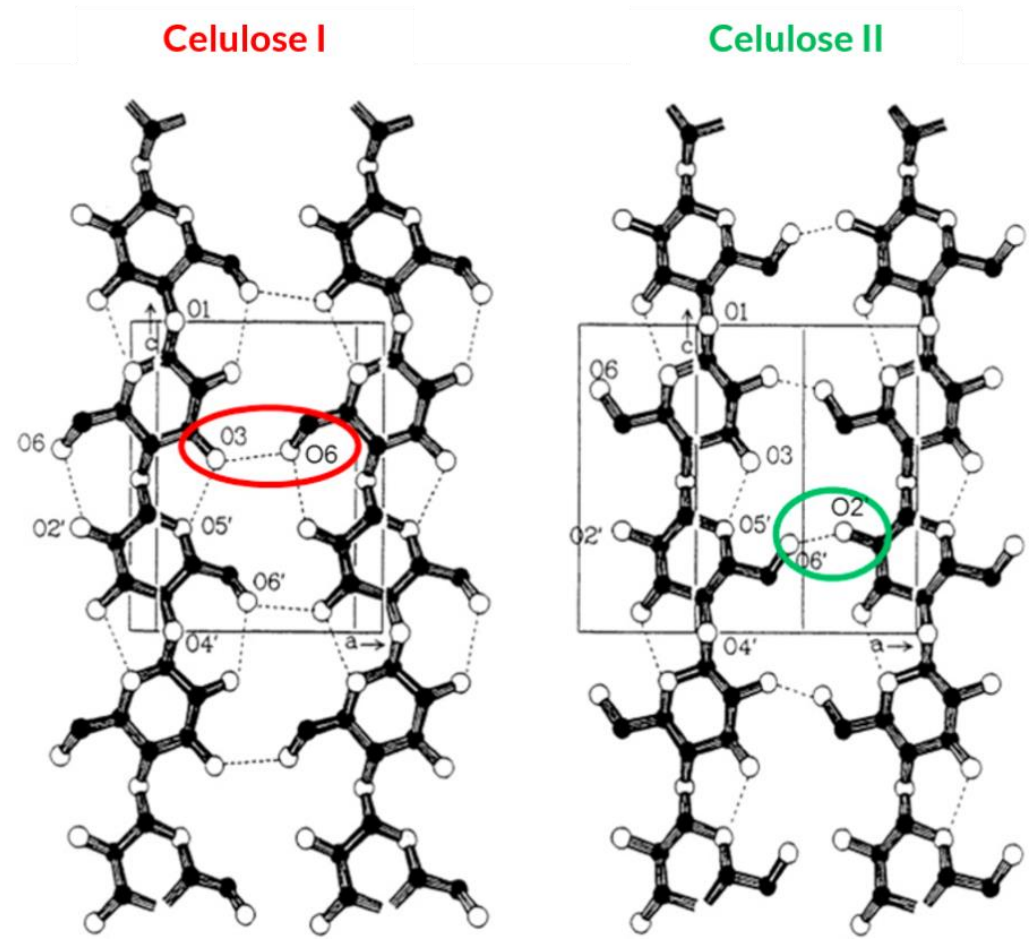

Fonte: NAGARAJAN et al., 2017.

Devido à sua estrutura cristalina altamente organizada, a celulose de linter só pode ser completamente dissolvida após a mercerização (RAMOS et al., 2005). A difusão dos íons alcalinos entre as cadeias de celulose resulta na separação física das mesmas e, consequentemente, quebra de ligações hidrogênio intermoleculares. A inserção do álcali aquoso dentro dos cristais de celulose nativa implica em um intumescimento sendo tal expansão traduzida pelo aumento nos diâmetros das microfibrilas (DINAND et al., 2002). A difusão por entre as cadeias dos domínios cristalinos leva a redução da cristalinidade da celulose, o que favorece o processo de dissolução. A mercerização pode reduzir o índice de cristalinidade e modificar a distribuição do tamanho dos poros, fatores importantes para posterior dissolução em sistema LiCl/DMAc (RAMOS et al., 2005; CIACCO et al., 2008). 
O processo de mercerização também promove a purificação da celulose, pois remove impurezas como ceras, hemiceluloses, pectinas e sais minerais eventualmente presentes, Quando hemiceluloses estão presentes, dependendo do teor das mesmas, a eliminação pode levar a um aumento na cristalinidade, pois hemiceluloses se encontram em regiões não cristalinas (STANA-KLEINSCHEK; STRNAD; RIBITSCH, 1999).

A modificação na estrutura supramolecular e morfológica da celulose causada pela mercerização é de fundamental importância para aumentar, ou até mesmo viabilizar a solubilidade de celuloses, como é o caso do linter em LiCl/DMAc (RAMOS et al., 2005; ASS; BELGAGEM; FROLLINI, 2006; CIACCO et al., 2008).

No presente estudo, a celulose de linter usada foi submetida à mercerização, previamente à dissolução.

\subsection{Solubilização da Celulose em Cloreto de lítio/Dimetilacetamida}

O sistemas de solvente cloreto de lítio /N,N-dimetilacetamida (LiCl/DMAc) é usado na derivatização da celulose em meio homogêneo pelo fato de a celulose ser insolúvel em água e em grande parte dos solventes convencionais, e porque nenhum dos componentes do sistema reage quimicamente com as moléculas de celulose (ASS; FROLLINI; HEINZE, 2004).

A dissolução da celulose em $\mathrm{LiCl} / \mathrm{DMAc}$ tem a finalidade de promover o intumescimento inter e intracristalino da celulose, desagregar a estrutura cristalina da celulose e promover a solvatação das cadeias (FIDALE, 2010). De modo geral, a difusão do solvente para o interior da estrutura da celulose aumenta o grau de separação das cadeias poliméricas até chegar à condição de solução que corresponde às cadeias totalmente isoladas e solvatadas (Figura 12) (OLSSON; WESTMAN, 2013).

Figura 12. Representação esquemática do arranjo das cadeias poliméricas em diferentes estágios da dissolução.

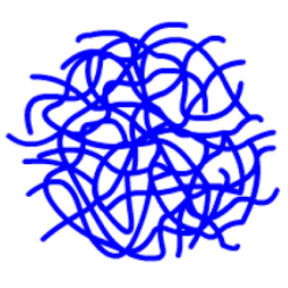

Estado sólido

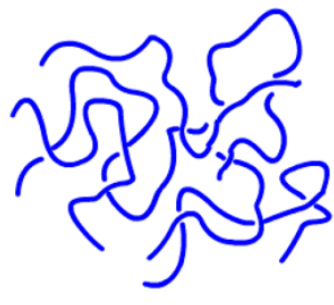

Intumescimento

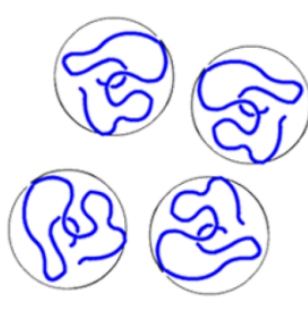

Solução

Fonte: FERREIRA, 2018. 
A dissolução da celulose resulta na formação de ligações hidrogênio fortes entre os grupos hidroxila da $\mathrm{UAG}$ e íons $\mathrm{Cl}^{-}$pouco solvatados, assim como interações coulômbicas com cátions $\mathrm{Li}^{+}$solvatados. A solubilização pode ser dividida em cinco etapas (RAMOS et al., 2005): (1) penetração do solvente na parede da fibra; (2) ruptura da fibra e da estrutura fibrilar; (3) formação de fragmentos; (4) isolamento da celulose; (5) dissolução celulose. No geral, pode ser considerado a formação de um complexo [Li.xDMAc] ${ }^{+} \mathrm{Cl}^{-}$envolvendo íons do cloreto de lítio e as moléculas do solvente (Figura 13) (MORGENSTERN; KAMMER, 1996). Os ânions $\mathrm{Cl}^{-}$formam ligações hidrogênio com os prótons hidroxílicos da celulose e não há indícios de interações entre os prótons hidroxílicos da celulose e os grupos carbonila presentes nas moléculas de DMAc (ZHANG et al., 2014a).

Figura 13. Esquema da interação entre os íons $\mathrm{Li}^{+}$e $\mathrm{Cl}^{-}$e DMAc quando a celulose se dissolve no sistema LiCl/DMAc.

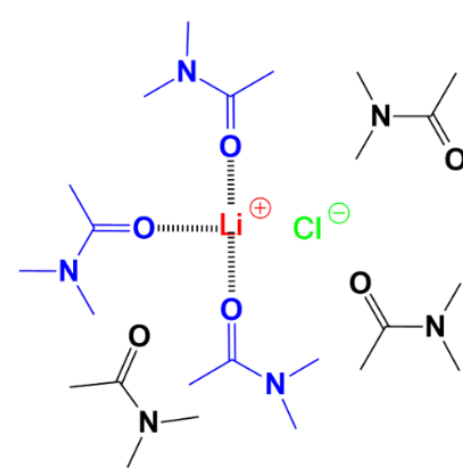

DMAc/LiCl

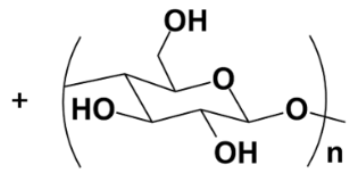

Celulose
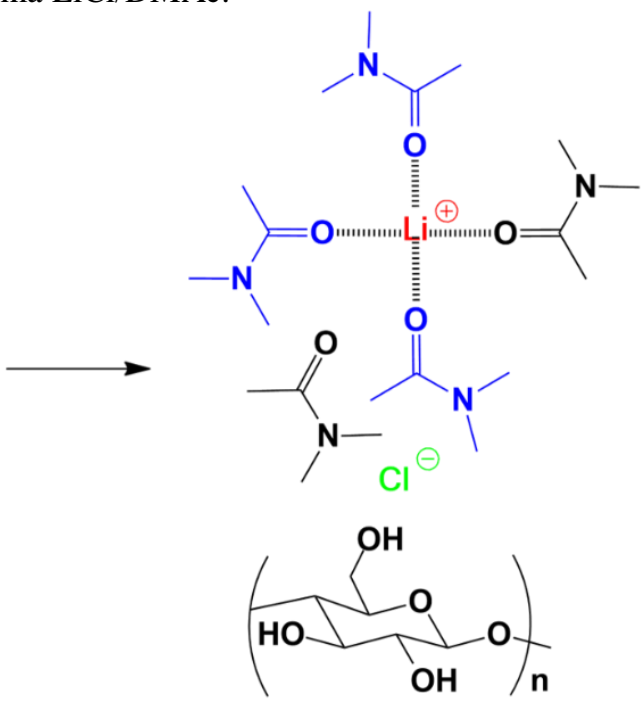

Complexo [Li.xDMAc ${ }^{+} \mathrm{Cl}^{-}$

Fonte: adaptado ZHANG et al., 2014.

Este sistema de solvente se mostrou útil para a dissolução da celulose, sendo amplamente utilizado (RAMOS et al., 2005; ZHANG et al., 2014a; LAVANYA; CLARA; NATCHIMUTHU, 2017; SILBERMANN et al., 2017).

Algo a ser levado em consideração na dissolução é a possibilidade de ocorrer agregação das cadeias de celulose no meio (RAMOS et al., 2011a; RODRIGUES et al., 2014). Para a dissolução, a celulose deve passar por um intumescimento que permita acesso do solvente aos domínios cristalinos. No entanto, este processo pode não desintegrar completamente as regiões ordenadas, dando origem a agregados em solução (RAMOS, 2005). A agregação se refere às interações macromolécula/macromolécula em solução que são 
irreversíveis e são responsáveis pela dificuldade na acessibilidade dos agentes esterificantes (HULT; LARSSON; IVERSEN, 2001).

Uma grande vantagem do emprego do sistema LiCl/DMAc como solvente é a sua capacidade de dissolver celuloses de diferentes massas molares (MMs) e índices de cristalinidade $\left(\mathrm{I}_{\mathrm{C}}\right)$, incluindo linters de algodão e celulose bacteriana (KOSTAG et al., 2019).

No presente estudo, o sistema de solvente LiCl/DMAc foi utilizado na dissolução para posterior esterificação da celulose de linter.

\subsection{Síntese de Ésteres de Celulose}

Ésteres de celulose foram os produtos pioneiros na química da celulose, e continuam os mais importantes derivados (KLEMM et al., 1998). A pesquisa sobre a conversão da celulose em ésteres surgiu pelo fato de a celulose decompor-se abaixo de seu ponto de fusão tornando o seu processamento em estado fundido impossível, e também pelo fato ser insolúvel em água e na maioria dos solventes orgânicos convencionais devido a sua rede de ligações hidrogênio intra e intermoleculares (MARK et al., 1988). A derivatização da celulose em ésteres de celulose resulta em materiais que podem ser processados no estado fundido, ou solubilizados.

A derivatização química da celulose em meio homogêneo ocorre por meio da adição do reagente esterificante após a solubilização. Os anidridos ácidos são utilizados como doadores de grupo acila, tendo sido observadas elevadas taxas de conversão para muitos anidridos quando utilizadas grandes quantidades de reagente (reação não estequiométrica) (CHEN et al., 2018). $\mathrm{Na}$ reação de esterificação da celulose utilizando anidridos ácidos ocorre a formação de ácido carboxílico como produto secundário.

Cloretos ácidos ou cloretos de acila também são usados como doadores de grupos acila via reação de esterificação. Considerando o reagente, o átomo de cloro possui par de elétrons não-compartilhados que conjuga com o grupo carbonila. Os elétrons deslocalizados do cloro no sentido do átomo de $\mathrm{C}$ diminuem seu caráter eletrofílico. A interação entre os elétrons nãocompartilhados do orbital 3p do cloro com o átomo de carbono é menos eficiente, por exemplo, que a interação similar de átomo de oxigênio de anidridos, em que o par de elétrons nãocompartilhados se encontra em orbital 2 p, e a doação de densidade de elétrons é menos efetiva no cloreto de acila. Assim, a diminuição do caráter eletrofílico do átomo de carbono é menor, e o mesmo é mais reativo frente à nucleófilos que carbonos do grupo carbonila de anidridos, por exemplo. O íon cloreto que se desloca (um bom grupo de saída) abstrai um próton da hidroxila celulósica que reagiu com o grupo carbonila, gerando ácido clorídrico, o qual reage 
com amina presente no meio, que deve ser estéricamente impedida (como a trietilamina, Figura 14), para atuar somente como base, e não como nucleófilo.

No presente estudo foram utilizados anidrido hexanóico e cloreto de benzoíla como agentes esterificantes (Figura 14).

Figura 14. Reação de esterificação da celulose.

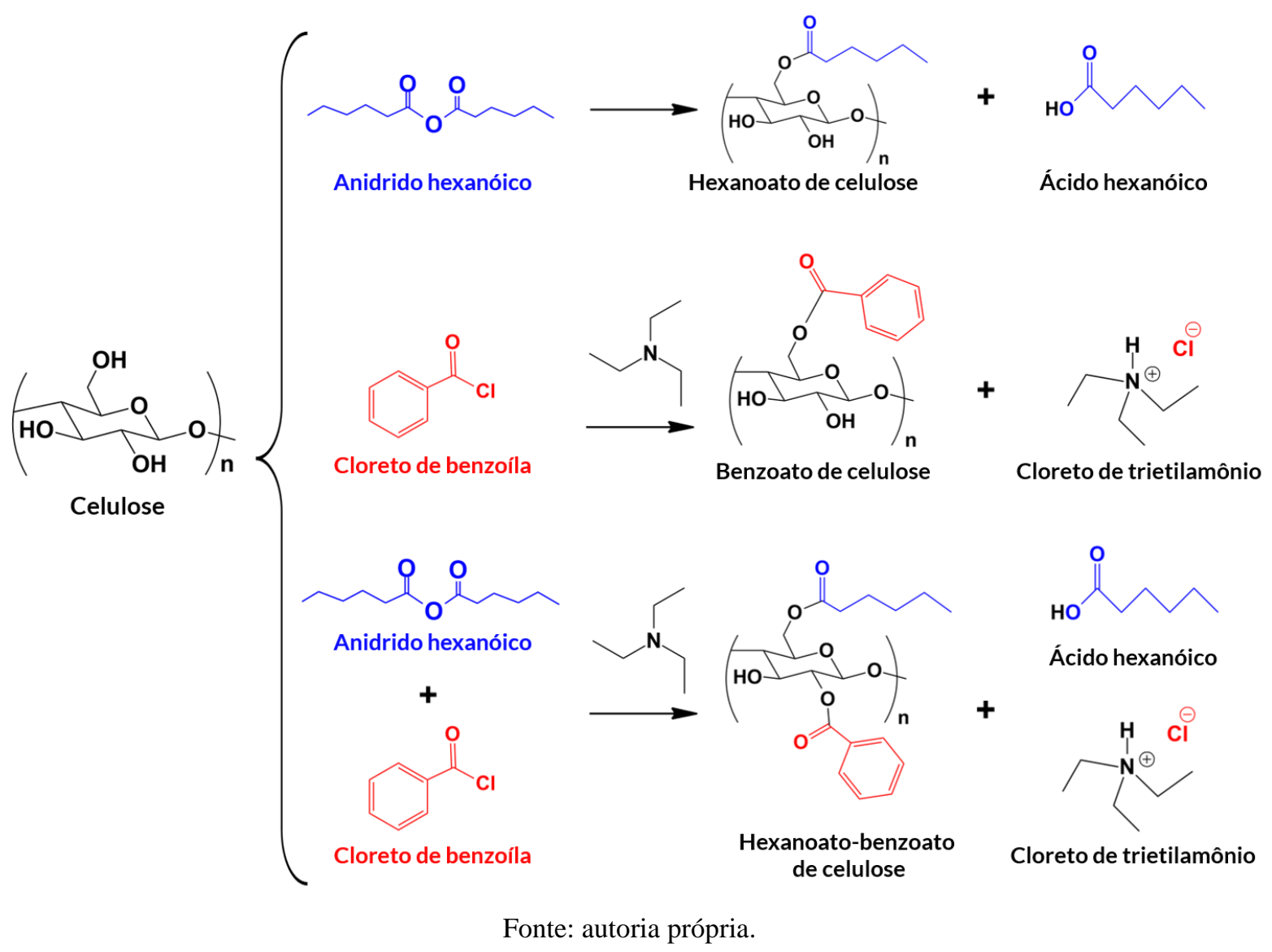

Quando a celulose é solubilizada, as interações intermoleculares são rompidas e, em princípio, as cadeias são separadas. A solubilização permite o acesso das espécies reativas a um maior número de hidroxilas presentes na cadeia, aumentando o grau e a homogeneidade de substituição, a qual se refere ao número médio de hidroxilas modificadas por UAG (KLEMM et al., 1998; NASIR et al., 2017). A distribuição dos substituintes ao longo de uma cadeia é referente à homogeneidade da substituição. Em derivados parcialmente substituídos, há três possibilidades de não uniformidade na introdução dos grupos substituintes: não-uniformidade dentro da UAG; não-uniformidade ao longo da cadeia e não-uniformidade entre cadeias (Figura 15). A homogeneidade da substituição é determinada principalmente pela acessibilidade dos grupos hidroxila e pela diferença de reatividade entre os grupos hidroxila. A 
hidroxila ligada ao carbono primário $\mathrm{OH}_{(6)}$ é a mais reativa por estar menos impedida estericamente (ASS; CIACCO; FROLLINI, 2006), sendo portanto a primeira hidroxila a ser substituída na derivatização, originando derivados parcialmente substituídos. O interesse na derivatização em meio homogêneo decorre principalmente do fato de que o grau médio de substituição (GS) pode ser mais eficientemente controlado, ajustando-se a razão molar do reagente adicionado.

Figura 15. Representação esquemática dos tipos de uniformidade da derivatização da celulose.

Não-uniformidade dentro da UAG

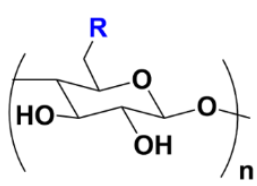

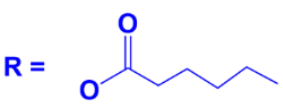

ou

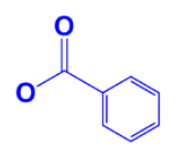

Não-uniformidade ao longo da cadeia

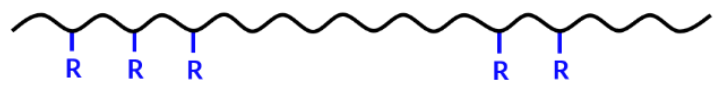

Não-uniformidade entre cadeias

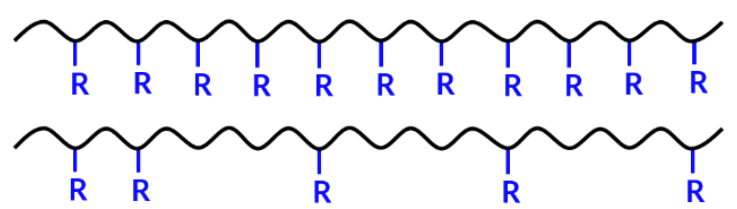

Fonte: adaptado KLEMM et al., 1998.

O grau médio de substituição (GS) de celulose pode ser definido como o número de grupos substituintes ligados aos três grupos hidroxila por UAG após a funcionalização. É um fator importante que dita várias propriedades de derivados de celulose, como por exemplo, a solubilidade em solventes orgânicos ou aquosos e biocompatibilidade (TRIVEDI; FARDIM, 2019).

A aplicação dos derivados de celulose depende especificamente do tipo de substituinte e do grau médio de substituição do mesmo (BLACHECHEN; SOUZA; PETRI, 2012) uma vez que a introdução destes grupos na cadeia de celulose altera significativamente algumas propriedades do biopolímero, tal como densidade, rede de ligações hidrogênio, volume molar, massa molar, capacidade calorífica, temperatura de transição vítrea, estabilidade térmica, dentre outras.

No presente estudo foram sintetizados em meio homogêneo ésteres de celulose (hexanoatos, benzoatos, e ésteres mistos, hexanoato-benzoatos de celulose) com diferentes graus médios de substituição utilizando anidrido hexanóico e cloreto de benzoíla como reagentes esterificantes.

Após a síntese e caracterização dos ésteres obtidos, soluções foram preparadas a partir dos mesmos tendo-se como objetivo submetê-las a eletrofiação. 


\subsection{Eletrofiação: Preparação de Mantas}

Materiais de escala nanométrica têm atraído interesse devido à possibilidade de obtenção de materiais com excelentes propriedades, tais como propriedades mecânicas superiores, elevada área superficial e ainda grande variedade de funcionalidade nas superfícies (RIVERO et al., 2015; PENG et al., 2016).

Diversas técnicas são utilizadas para produção de fibras em escala nanométrica, dentre elas destaca-se a eletrofiação por ser uma técnica relativamente simples e versátil. A eletrofiação é utilizada no processamento de polímeros e cerâmicas, permitindo a formação de fibras contínuas com diâmetros que podem variar na ordem de micrômetros até nanômetros (AGARWAL; WENDORFF; GREINER, 2008). A técnica de eletrofiação (electrospinning) é conhecida desde a década de 1930, porém, somente com o surgimento de novas aplicações nanotecnológicas esta técnica foi redescoberta. Quando os diâmetros das fibras são reduzidos de micrômetros para nanômetros características excepcionais como, desempenho mecânico (EZATPOUR et al., 2014) e grande área de superfície (PENG et al., 2016) em relação ao volume exercem grande influência nas fibras.

A eletrofiação permite a produção de fibras com diâmetros em escala nanométrica (nanofibras: <100 nm) (ISO/TS 27687) e submicrométrica (fibras ultrafinas: >100 e <1000 nm) (SON et al., 2004; ZHANG et al., 2016; SANTOS et al., 2017) a partir de uma solução polimérica submetida à elevada tensão. A eletrofiação é baseada no estiramento uniaxial de um jato viscoelétrico derivado de uma solução polimérica.

O processo inicia com uma elevada voltagem aplicada para criação de um jato de solução de polímero eletricamente carregado através de um capilar ou agulha. A carga é induzida sobre a superfície da solução por meio do campo elétrico. Repulsões eletrostáticas mútuas entre cargas da superfície e forças coulômbicas exercidas pelo campo elétrico geram uma força diretamente oposta à tensão superficial. Com o aumento da intensidade do campo elétrico, a superfície hemisférica da solução na ponta do tubo capilar alonga-se para formar uma forma cônica conhecido como Cone de Taylor (Figura 16) (TAYLOR, 1969). Desse modo, para que haja a formação do cone, a voltagem aplicada deve ser suficientemente alta para que as forças eletrostáticas superem a tensão superficial da gota de solução polimérica (COSTA et al., 2012). O Cone de Taylor foi nomeado após Sir Geoffrey Ingram Taylor, devido ao seu trabalho publicado descrevendo a matemática do perfil da superfície, sendo formado pelo equilíbrio das três forças de tensão superficial, carga superficial e pressão interna do fluido. A forma final depende das propriedades viscoelásticas do fluido. A intensidade do campo elétrico 
suficientemente alta fará com que o líquido seja ejetado da ponta do cone, resultando em eletropulverização (electrospray) ou eletrofiação (electrospinning) (MITCHELL, 2015).

Figura 16. Aparelho utilizado para técnica de eletrofiação (a) e esquema de funcionamento do equipamento (b).

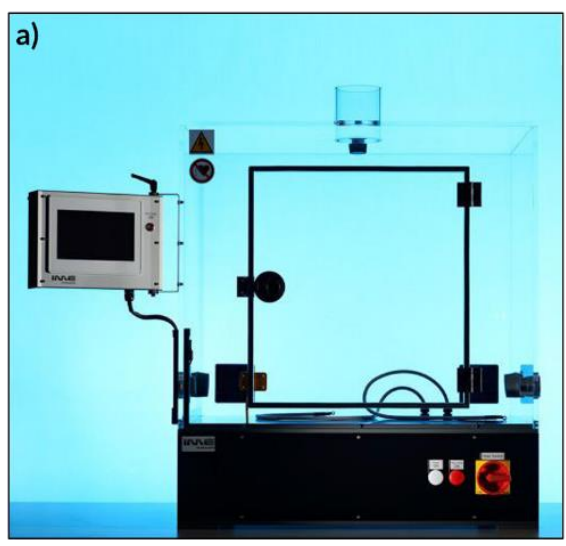

b)

\section{Cone de Taylor}
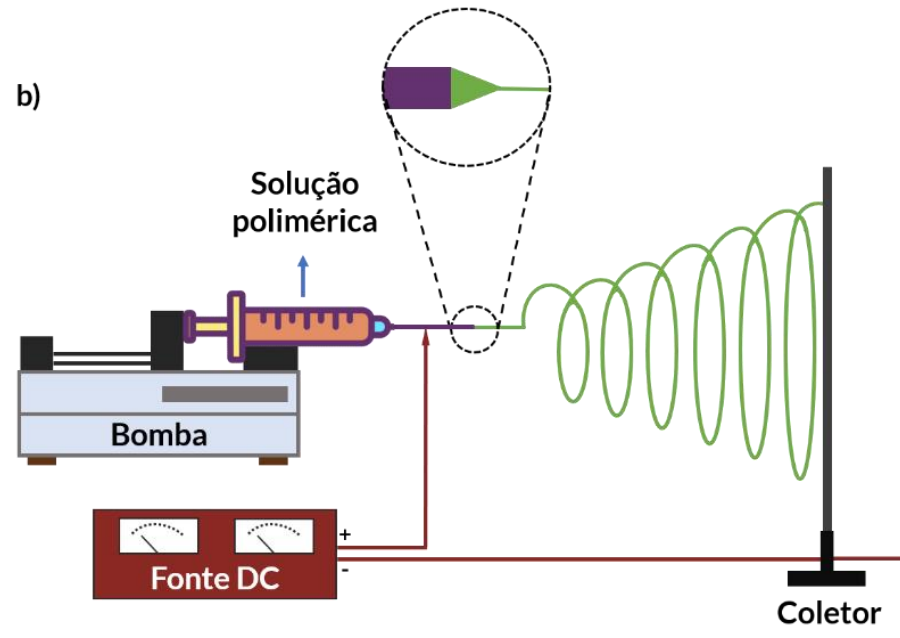

Fonte: (a) IME TECHNOLOGIES, 2019; (b) autoria própria.

Quando o campo elétrico atinge um valor crítico em que a força repulsiva eletrostática supera a força de tensão superficial, um jato carregado da solução é ejetado a partir da ponta do cone. À medida que o jato caminha até o coletor, o seu diâmetro diminui como resultado da evaporação do solvente. Com a diminuição do diâmetro do jato, a densidade de carga da superfície aumenta e as forças repulsivas resultantes dividem o jato em vários jatos menores. Este processo pode ser realizado várias vezes, levando a muitos pequenos jatos que são finalmente acumulados na superfície do coletor, que no presente estudo foi do tipo estático, o que resulta em uma teia não tecida de fibras (mats) (RENEKER; YARIN, 2008). As fibras são formadas de forma contínua e são tipicamente depositadas como um arranjo aleatório sem preferência de direção dos eixos de fibra.

Existem seis forças principais que agem sobre o jato de solução polimérica carregado:

1) Força gravitacional;

2) Forças eletrostáticas que conduzem o jato carregado da ponta da agulha até o coletor;

3) Forças coulômbicas de repulsão, as quais induzem a separação de espécies de mesma polaridade adjacentes presentes no jato de solução e são, portanto, responsáveis pelo alongamento do mesmo até o coletor;

4) Forças viscoelásticas, as quais tendem a impedir o estiramento do jato de solução carregado; 
5) Tensão superficial, a qual também desfavorecem o estiramento da superfície do jato carregado;

6) Forças de arrasto geradas pelo atrito entre o jato carregado e o ar circundante (MITUPPATHAM; NITHITANAKUL; SUPAPHOL, 2004).

Devido à combinação dessas forças, o jato carregado eletricamente atravessa o ar em uma trajetória reta apenas por uma curta distância, após, passa por processos de instabilidade e alongamento, até se solidificar e depositar sob a forma de fibras no coletor (MIT-UPPATHAM; NITHITANAKUL; SUPAPHOL, 2004).

O processo de eletrofiação é, no geral, conduzido à temperatura ambiente, sob condições atmosféricas. Também é aconselhável que o processo seja realizado dentro de uma câmara especial com sistema de ventilação, devido à volatilidade e toxicidade de muitos solventes e/ou polímeros utilizados (RODRIGUES, 2014) e umidade controlada, visto que esta influencia o tempo de secagem das fibras no processo (LI; WANG, 2013).

A técnica pode ser utilizada para grande variedade de polímeros. Novas aplicações desta tecnologia têm sido recentemente investigadas, tais como utilização no setor eletrônico (em supercapacitores) (LIU et al., 2017), no setor energético (em células de combustíveis e armazenamento de hidrogênio) (PENG et al., 2016), no setor biológico/médico (na engenharia de tecidos, dispositivos médicos e próteses neurológicas) (GABRIEL et al., 2017).

Os parâmetros envolvidos no processo de eletrofiação são fundamentais e influenciam tanto os processos cinéticos relacionados ao jato de solução polimérica, como também relacionados à morfologia das fibras formadas. São eles: parâmetros de solução como concentração e condutividade, massa molar média do polímero e tensão superficial da solução polimérica; parâmetros do processo como tensão aplicada, taxa de vazão e distância entre ponta da agulha e o coletor; parâmetros ambientais como temperatura da solução polimérica e umidade relativa do ar (WEI et al., 2010).

Os parâmetros da solução estão intimamente relacionados com as propriedades físicoquímicas tanto dos polímeros como dos solventes utilizados, assim como também as interações do tipo polímero-solvente. A concentração do polímero em solução, e consequentemente sua viscosidade, são parâmetros muito importantes. A massa molar do polímero também tem um efeito importante nas morfologias das fibras. Em princípio, a massa molar reflete o emaranhamento de cadeias poliméricas em soluções (LI; WANG, 2013). Para a obtenção de fibras uniformes e de morfologia mais cilíndrica, sem que haja a presença de partículas esféricas (contas, beads) ou fibras com contas, faz-se necessário um certo grau de emaranhamento de cadeias na solução polimérica, o que corresponde a um valor de concentração 
(viscoelasticidade) mínimo. Assim, com o aumento da concentração do polímero e mantendose fixos os demais parâmetros do processo, há uma tendência em aumentar o diâmetro das fibras.

A baixas concentrações de polímero, a formação de fibras mais finas é favorecida, no entanto, o grau de emaranhamento das cadeias poliméricas é pequeno, o que pode causar uma instabilidade capilar na extremidade do jato, podendo evoluir para um espalhamento eletrostático como resultado da tensão superficial (fenômeno conhecido como eletropulverização, electrospraying), ao invés da eletrofiação (DEITZEL et al., 2001). Como consequência deste fenômeno, beads podem ser formados ou mesmo fibras com contas (COSTA et al., 2012). Com relação à formação de fibras contendo beads durante o processo de eletrofiação, o diâmetro dos mesmos e o espaçamento entre eles está diretamente relacionado com o diâmetro das fibras formadas.

As concentrações de solução de polímero desempenham um papel importante na formação de fibras durante o processo de eletrofiação. Quatro concentrações críticas são observadas:

1) Quando a concentração é muito baixa, micro (nano) partículas poliméricas são obtidas. Neste momento, ocorre electrospray em vez de electrospinning devido à baixa viscosidade e altas tensões superficiais da solução;

2) Quando a concentração é um pouco maior, uma mistura de beads (contas) e fibras será obtida;

3) Quando a concentração é adequada, nanofibras são obtidas;

4) Quando a concentração for muito alta, fibras não nanométricas ou microfitas em forma de hélice podem ser observadas (LI; WANG, 2013).

Com relação ao aparecimento de beads, quanto mais finas as fibras formadas, menor será a distância entre os beads e menor será o diâmetro dos mesmos (JAEGER; SCHÖNHERR; VANCSO, 1996). Ainda, elevadas viscosidades das soluções poliméricas a serem eletrofiadas favorecem a formação de fibras sem a presença de beads (FONG; CHUN; RENEKER, 1999).

A condutividade elétrica da solução polimérica desempenha importante papel na morfologia das fibras produzidas via técnica de eletrofiação. Geralmente, o aumento da condutividade elétrica da solução, com a adição de um sal, por exemplo, resulta em maior mobilidade dos íons em solução e, com a aplicação de um campo elétrico externo, há a orientação das cargas e um maior alongamento da gota, com consequente redução no diâmetro das fibras formadas (COSTA et al., 2012). Destaca-se que o aumento na densidade de cargas 
da solução também reduz a probabilidade de formação de fibras com beads (FONG; CHUN; RENEKER, 1999).

Em um processo de eletrofiação, não é possível que sejam feitas recomendações gerais com relação a concentrações particulares, viscosidades resultantes, condutividades elétricas e tensões superficiais. Os valores ideais para estes parâmetros podem variam consideravelmente a depender do sistema polímero-solvente adotado. Ainda, a rápida evaporação do solvente adotado, no caso daqueles com baixo ponto de ebulição e alta pressão de vapor, pode influenciar negativamente o processo de eletrofiação a partir de soluções poliméricas, com consequente geração de regiões filmogênicas (GREINER; WENDORFF, 2007).

Dentre os parâmetros de processamento envolvidos na técnica de eletrofiação, a voltagem aplicada é um fator crucial. Durante o processo de eletrofiação, há a formação de fibras apenas quando se aplica uma voltagem acima do valor limite de voltagem necessário para que o jato de solução polimérica carregado seja ejetado do cone de Taylor (LI; WANG, 2013). No entanto, a influência da voltagem aplicada no diâmetro das fibras formadas apresenta controvérsias (RENEKER; CHUN, 1996; ZHANG et al., 2005).

Em baixas tensões aplicadas, o cone de Taylor se forma na ponta de uma gota pendente. Conforme a tensão é elevada, o volume da gota diminui até o cone ser formado na ponta da agulha. Porém, se a voltagem aplicada for muito elevada, o jato da fibra é ejetado de dentro do capilar, esse fato pode estar associado a um aumento da presença de beads no mat (Figura 17) (SILL; RECUM, 2008).

A distância entre a extremidade da agulha até a placa coletora deve ter um valor mínimo para garantir total evaporação do solvente, assim como um valor máximo para que não ocorra desestabilização do cone de Taylor (COSTA et al., 2012). A distância também tem influência no diâmetro da fibra e pode definir se o resultado final do processo será de electrospinning ou electrospraying (SILL; RECUM, 2008).

Figura 17. Efeito da variação de voltagem aplicada na formação do cone de Taylor.

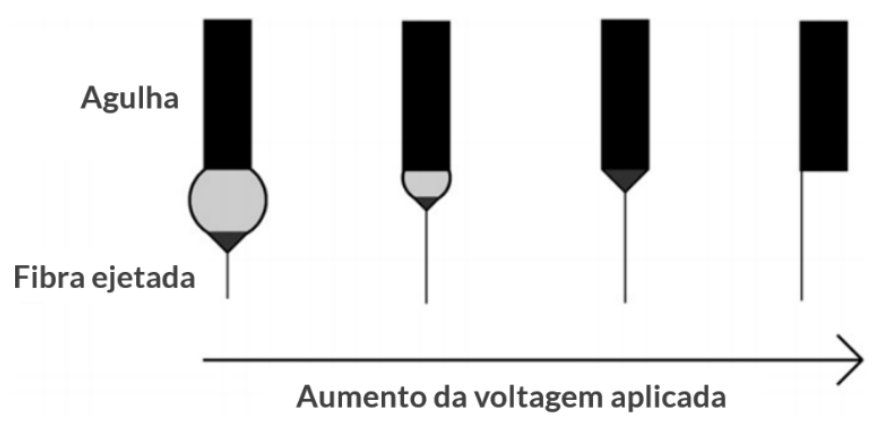

Fonte: adaptado SILL; RECUM, 2008. 
No presente estudo, teve-se como meta usar os ésteres de celulose sintetizados na preparação de mantas (mats) constituídos por fibras ultrafinas/nanofibras, a partir de soluções do sistema solvente tetraidrofurano/dimetilacetamida (THF/DMAc).

Mantas obtidas via eletrofiação apresentam possibilidade de aplicação em imobilização de enzimas, como será apresentado posteriormente.

\subsection{Esferas a partir de Ésteres de Celulose}

Partículas esféricas com diâmetros na escala de micrômetros a milímetros (Figura 18), podem ser obtidas a partir de soluções de polímeros, como celulose, e podem ser usadas em muitas aplicações que variam desde cromatografia e imobilização de proteínas, até liberação controlada de fármacos (GERICKE; TRYGG; FARDIM, 2013; HOSSAIN; PATEL; AHMED, 2014).

Figura 18. Esferas de celulose com diferentes tamanhos.

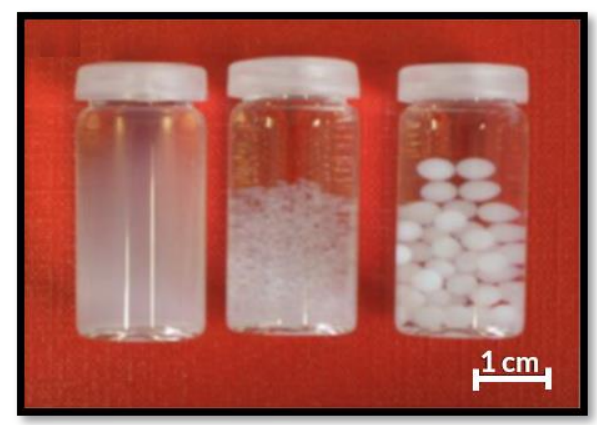

Fonte: GERICKE; TRYGG; FARDIM, 2013.

Esferas de celulose e seus derivados podem ser obtidas empregando-se soluções em diferentes solventes, e as mais variadas técnicas de modelagem como gotejamento, emulsão, dispersão, aerossol, dentre outras (GERICKE; TRYGG; FARDIM, 2013). Em princípio, a produção de esferas pode ser simplificada em três etapas: (1) dissolução da celulose (ou um derivado da celulose), (2) modelagem da solução de polissacarídeo em partículas esféricas, e (3) transição sol-gel e solidificação da solução partículas para contas. Além disso, vários pós e pré-tratamentos podem ser aplicados para ajustar determinadas propriedades (GERICKE; TRYGG; FARDIM, 2013). 
As microesferas podem ser preparadas com diferente porosidade (Figura 19) podendo a mesma ser externa ou interna, ou mesmo uma combinação de ambas. As microesferas com maior porosidade exibem maior área superficial e menor densidade (HOSSAIN; PATEL; AHMED, 2014).

Figura 19. Micrografias de microesferas de celulose com diferentes porosidades: (a) baixa porosidade e (b) elevada porosidade.
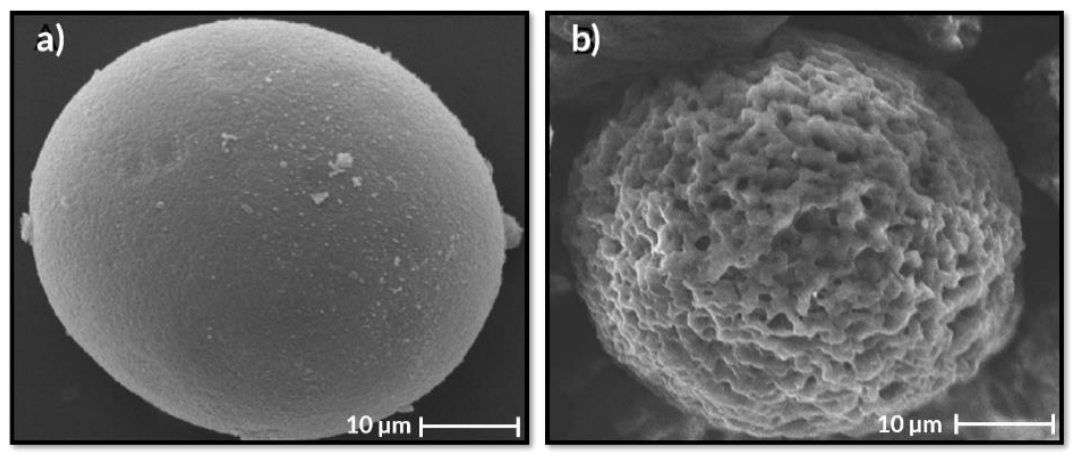

Fonte: DU et al., 2010.

As microesferas com alta porosidade e alta estabilidade a altas pressões são de especial interesse na área cromatográfica, com aplicações direcionadas a técnicas de separação. As microesferas de celulose e de celulose quimicamente modificada estão sendo usadas em diversas aplicações cromatográficas, como em Cromatografia de Exclusão por Tamanho (ZHANG et al., 2014b). Outras aplicações para as microesferas de celulose e seus derivados são encontradas no uso destas no suporte de síntese de fases sólidas (YAN; HORÁK; HAMMOND, 2013), processos de troca iônica (HIROTA; TAMURA, 2009), remoção de íons de metais pesados (LUO et al., 2016), e imobilização de enzimas (WU et al., 2013; KIM et al., 2017).

No presente estudo, ésteres de celulose foram usados como matéria-prima para preparação de esferas visando aplicar estes materiais em imobilização de enzimas. $O$ conhecimento que se tem sobre os ésteres estudados (hexanoato de celulose, benzoato de celulose e hexanoato-benzoato de celulose) indica que a abordagem do presente estudo é sem precedentes. 


\subsection{Imobilização Enzimática}

É crescente a utilização de filmes, mantas (mats) e esferas de derivados de celulose para aplicações biofuncionais. Um exemplo deste tipo de aplicação é a utilização como plataformas para imobilização de enzimas.

Enzimas são proteínas funcionais altamente específicas, eficientes e que podem atuar como catalisadores na indústria farmacêutica, no processamento de alimentos e no processo de biorremediação (para redução ou remoção de poluentes do meio ambiente). As enzimas, assim como os demais catalisadores, aumentam a velocidade de reações diminuindo a energia de ativação da reação, que é a diferença de energia entre o substrato ou reagentes iniciais e o estado de transição existente entre produto e substrato. Entretanto, as enzimas são consideradas catalisadores eficientes podendo acelerar reações em uma ordem de 107 vezes comparado à reação não catalisada (BERG et al., 2015).

As lipases (triacylglycerolacyl hydrolases EC 3.1.1.3), em específico, são utilizadas em reações de hidrólise, esterificação e transesterificação e reações de formação de amidas, lactonas, epóxidos, nitrilas, anidridos e glicosídeos (STERGIOU et al., 2013). Lipases são glicoproteínas ácidas de massa molar variando de 20.000 a 60.000 Da, composta por 102 resíduos de aminoácidos. Apresentam estrutura secundária composta por dobra padrão $\alpha / \beta$, em que o núcleo hidrofóbico é composto por $8 \beta$-fitas que formam uma folha- $\beta$ (sendo apenas a segunda fita antiparalela), conectada por $6 \alpha$-hélices (Figura 20a) (SCHRAG; CYGLER, 1997; MEHTA; BODH; GUPTA, 2017).

Existe uma relação entre a estrutura da enzima e sua função catalítica, uma vez que é a estrutura proteica que determina as interações entre enzima e substrato envolvidos na catálise. O substrato deve ser capaz de se ligar especificamente à enzima a fim de possibilitar sua transformação em produto. Assim, a estrutura do catalisador deve possuir um conjunto de interações que permitam a ligação com o substrato, expondo grupos capazes de interagir entre si formando o complexo enzima-substrato.

A região da enzima envolvida na formação do complexo enzimático é chamada de sítio ativo ou sítio catalítico, sendo este localizado em uma espécie de "fenda" formada a partir do enovelamento da estrutura terciária da enzima. Ele apresenta resíduos de aminoácidos, e as cadeias laterais são capazes de interagir com o substrato. O sítio catalítico da lipase é formado pela tríade catalítica Ser-His-Asp/Glu (Serina-Histidina-Aspartato/Glutamato) (Figura 20b), que é protegido por uma tampa hidrofóbica (lid). Quando a enzima está em sua conformação 
fechada, a tampa cobre o sítio ativo. Na presença de um substrato hidrofóbico, a lipase pode sofrer uma mudança conformacional, a tampa se abre expondo o sítio ativo e consequentemente aumentando a atividade enzimática (POUDEROYEN et al., 2001; DALLA-VECCHIA; NASCIMENTO; SOLDI, 2004).

Na tríade catalítica, o grupo nucleofílico é a serina e os dois aminoácidos localizados próximos a serina (aspartina e histidina) auxiliam na catálise de modo que arranjo espacial destes grupos favorece o aumento da nucleofilicidade do grupo hidroxila da serina (Figura 20b).

Figura 20. Estrutura 3D da lipase de Pseudomonas fluorescens (a) e tríade catalítica Ser-His-Asp (Serina-Histidina-Aspartato) (b).

a)

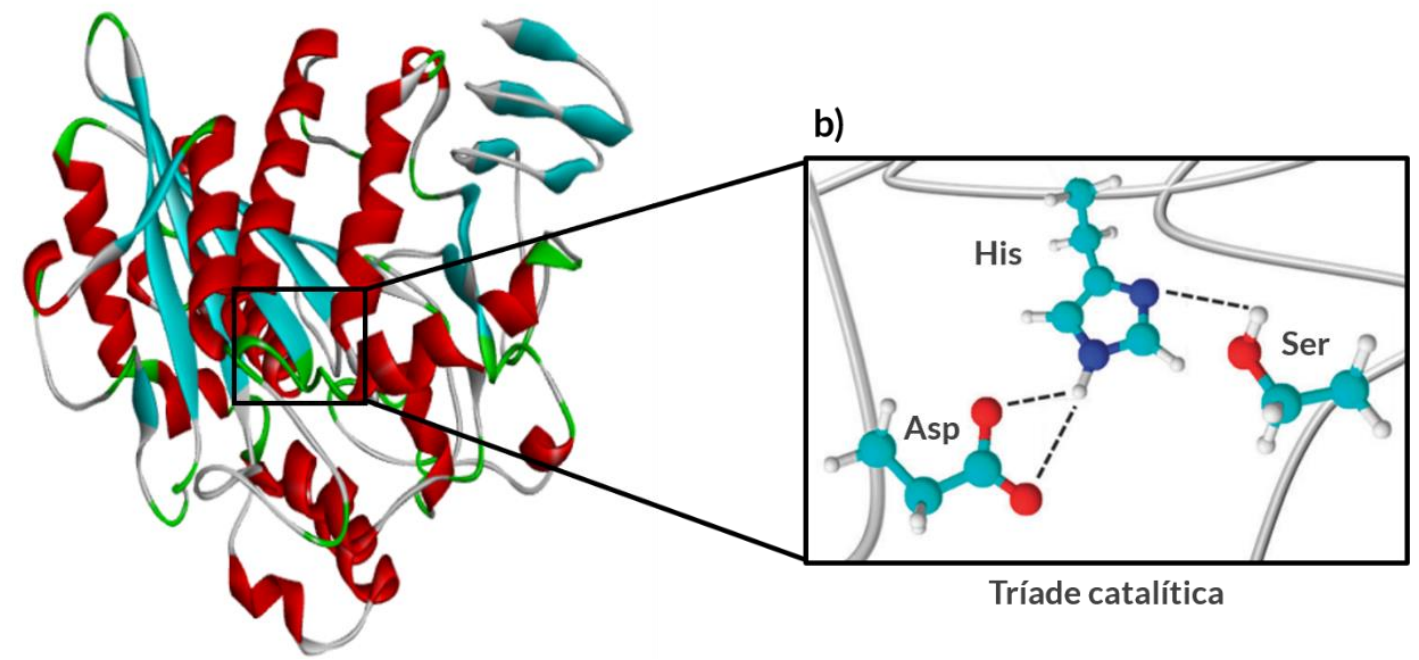

Fonte: (a) GUPTA; SINGH; PRAKASH, 2015; (b) COULEMBIER et al., 2012.

A utilização das lipases em síntese orgânica se deve a alguns fatores: o principal é que as lipases não necessitam de cofatores para exercerem sua atividade e desta maneira podem ser empregadas como um reagente; elas normalmente apresentam uma alta quimiosseletividade, regiosseletividade e estereosseletividade; muitas lipases estão disponíveis comercialmente ou podem ser facilmente obtidas em grandes quantidades de microrganismos, como fungos, leveduras e bactérias; a estrutura cristalina de muitas lipases já foi elucidada, facilitando consideravelmente o desenvolvimento de estratégias de design racional (KUMAR et al., 2016).

No entanto, para muitos processos industriais a utilização de enzimas é restrita, pois as condições operacionais diferem em muito das encontradas no meio natural da enzima, visto que possuem pH e temperatura ótimos (DURÁN; ESPOSITO, 2000; SCHMID et al., 2001). Assim, as enzimas estão sujeitas à inativação por fatores químicos, físicos ou biológicos, podendo ainda perder suas atividades quando estocadas, ou durante o uso. Para aumentar a 
eficiência de uma enzima em um determinado processo, pode ser necessário imobilizá-la, sem comprometer sua atividade catalítica (WANG; WANG; XU, 2006). A imobilização de enzimas leva a possibilidade de reuso da mesma, sem perda na atividade catalítica, o que proporcionaria redução de custo operacional em processos industriais (DICOSIMO et al., 2013).

Na imobilização de enzimas vários materiais podem ser utilizados como suportes. A busca por suportes economicamente viáveis, com maior resistência e biocompatibilidade, tem direcionado alguns estudos para os materiais lignocelulósicos. São materiais abundantes em vários resíduos agroindustriais como a biomassa, bem como outros biopolímeros.

Quando as enzimas são ligadas ou incorporadas a polímeros naturais, podem apresentar melhor atividade específica e estabilidade em comparação a atuação das mesmas quando isoladas (FANG, 2011). Ye et al. imobilizaram a lipase de Candida rugosa em membrana nanofibrosa de poli(acrilonitrila) modificada com quitosana e gelatina (YE et al., 2006). A atividade residual para lipase de Candida rugosa imobilizada em quitosana foi de $55 \%$, já para a enzima imobilizada em nanofibra modificada com gelatina foi de 60\%, após 10 ciclos. Como exemplos da utilização de plataformas de material celulósico contendo enzimas imobilizadas, pode-se citar biossensores (FU et al., 2015; PALANISAMY et al., 2017) e membranas de filtração (KONOVALOVA et al., 2016). Investigações sobre novos materiais, como suportes enzimáticos capazes de prolongar as atividades das enzimas por vários ciclos consecutivos, em muito podem contribuir para o avanço da área.

Existem quatro métodos que podem ser utilizados para imobilização de enzimas: adsorção, ligação covalente, ligação cruzada ou reticulação covalente (crosslinking) e encapsulamento (Figura 21).

Figura 21. Métodos de imobilização enzimática: adsorção, ligação covalente, ligação cruzada (crosslinking) e encapsulamento.

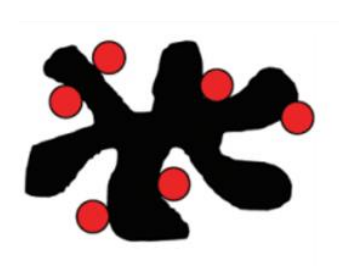

Adsorção

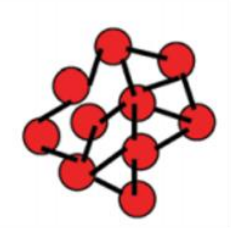

Ligação covalente

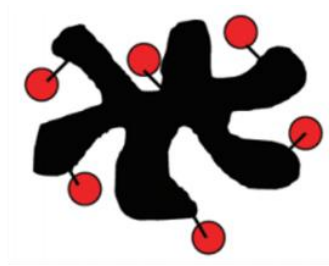

Ligação cruzada

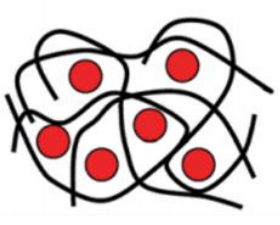

Encapsulamento

Fonte: adaptado ADLERCREUTZ, 2013.

A imobilização enzimática por adsorção física é um dos métodos mais simples de imobilização. Os mecanismos de adsorção são baseados em interações fracas como como forças de Van der Waals, interações eletrostáticas e hidrofóbicas (SASSOLAS; BLUM; LECA- 
BOUVIER, 2012). A enzima é dissolvida em solução e o suporte sólido é colocado em contato com a solução enzimática por um período sob condições adequadas que sustentam a atividade enzimática. Esta técnica apresenta desvantagens: as enzimas são fracamente ligadas ao suporte por fraca interação física, de modo que mudanças na temperatura, $\mathrm{pH}$ ou força iônica podem resultar em dessorção (MOHAMADA et al., 2015).

A imobilização por ligação covalente ocorre por meio do uso de agentes funcionalizantes (grupos tiois, epóxidos, vinilas e aminas) na etapa de ativação do suporte e, portanto, promove um maior custo na obtenção do biocatalisador imobilizado. A ligação covalente entre grupos funcionais não ativos da enzima e grupos reativos na superfície sólida do suporte é forte e efetiva, o que torna a imobilização por ligação covalente mais estável frente à imobilização por adsorção. Como as interações entre a enzima e o suporte são fortes, pode ocorrer perda da atividade catalítica causada por modificações na conformação da enzima (HOFFMANN et al., 2006).

A imobilização por ligação cruzada (crosslinking) utiliza reagentes multifuncionais, tal como o glutaraldeído, que reage diretamente com grupos amino da enzima. A técnica envolve a modificação química de resíduos de aminoácidos com a matriz. A imobilização com glutaraldeído é largamente empregada, pois a enzima geralmente é mantida em um ambiente semelhante ao seu meio natural, concedendo estabilidade às variações de $\mathrm{pH}$, presença de solventes orgânicos e temperaturas elevadas. Essa metodologia possui alguns pontos desfavoráveis, tais como baixa retenção de atividade e pouca reprodutibilidade (SASSOLAS; BLUM; LECA-BOUVIER, 2012).

A imobilização por encapsulamento ou aprisionamento consiste na retenção física do biocatalisador no interior de uma matriz polimérica, sem qualquer alteração estrutural ou interação com o centro ativo da enzima (MOHAMADA et al., 2015). A vantagem de usar esta técnica é que a enzima não interage quimicamente com o meio reacional, evitando sua desnaturação ou retardando a perda de atividade. Porém, as velocidades de difusão do substrato e produto através do suporte pode ser um fator limitante dependendo do tipo de material utilizado e das condições reacionais empregadas (ADLERCREUTZ, 2013),

Dentre o método de imobilização por encapsulamento pode-se destacar o encapsulamento por meio da eletrofiação, em que as enzimas são imobilizadas juntamente com a fibras (Figura 22a), e também, encapsulamento em esferas, em que as enzimas são imobilizadas juntamente com a esfera (Figura 22b).

As enzimas podem ser aplicadas em síntese orgânica por meio de reações de separação enantiomérica, ou seja, na preparação de compostos enantiomericamente enriquecidos. A 
Resolução Cinética Enzimática (RCE) ou resolução biocatalítica é uma técnica que é capaz de separar uma mistura racêmica utilizando catalisadores biológicos (enzimas) na resolução de substratos racêmicos. O termo resolução refere-se à separação total ou parcial dos componentes de um racemato (IUPAC, 2019), e o termo cinética refere-se às velocidades de reação distintas de cada estereoisômero (CARVALHO et al., 2006). Isto ocorre devido à quiralidade existente no sítio ativo da enzima, com o qual um enantiômero interage com mais facilidade que o outro, e assim um dos enantiômeros é convertido mais rapidamente. Assim sendo, a enzima converte preferencialmente um dos enantiômeros em produto, enquanto o outro enantiômero permanece intacto. Desse modo, esses compostos apresentarão propriedades físicas e químicas distintas podendo assim ser separados (WHITTALL; SUTTON, 2009).

Figura 22. Imobilização enzimática por (a) encapsulamento por meio da eletrofiação e (b) por encapsulamento em esferas.

a)

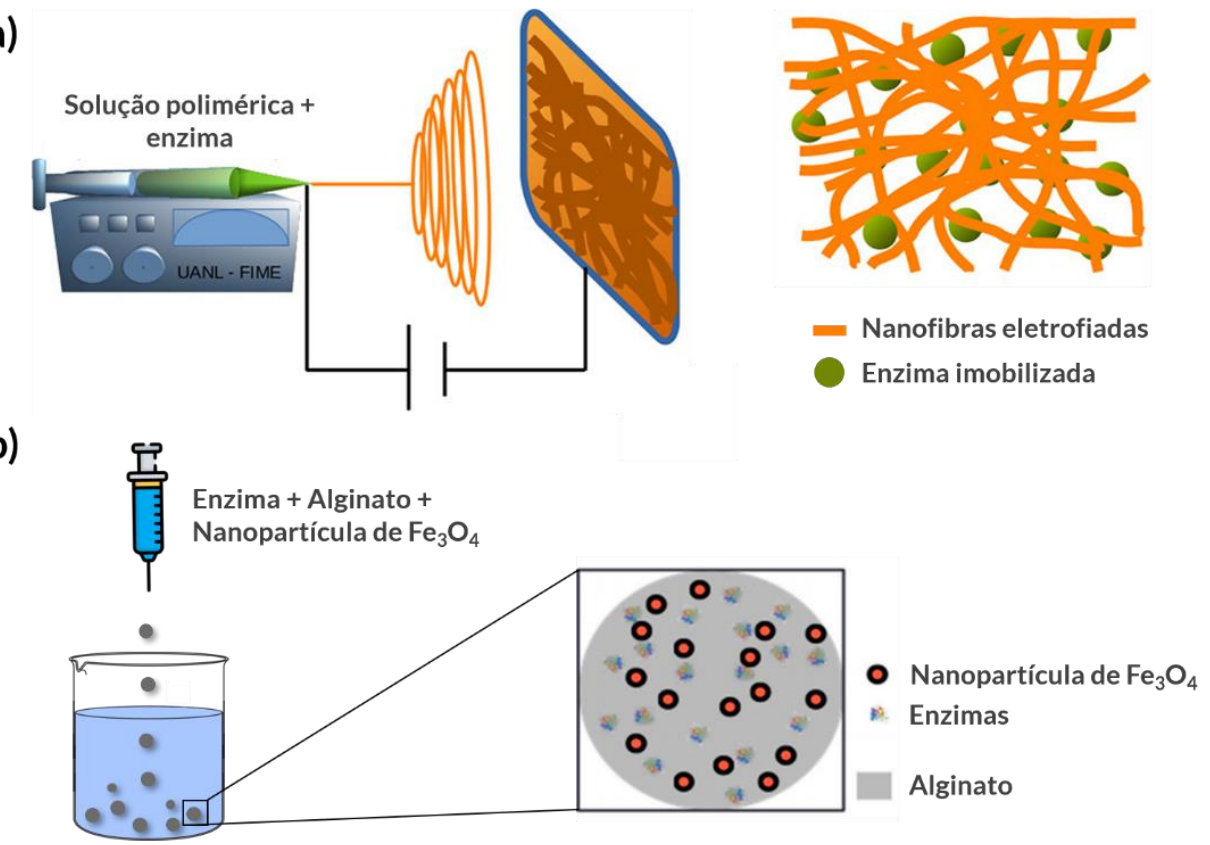

Fonte: (a) ROJAS-MERCADO et al., 2018; (b) YANG et al., 2014.

O poder de catálise das enzimas está relacionado à capacidade de estabilizar o estado de transição da reação gerando dois estados de transição diastereoisoméricos com diferentes energias de Gibbs, portanto com diferentes velocidades de reação (Figura 23). Os complexos enzima-substrato (EnzA e EnzB) formados apresentam diferentes valores de energia livre para seus respectivos estados de transição, consequentemente, um enantiômero se formará preferencialmente com relação ao outro. A diferença de energia livre de ativação $\left(\Delta \Delta G^{\neq}\right)$ caracteriza a seletividade da enzima na reação, sendo diretamente proporcional à razão entre as velocidades de formação de cada um dos enantiômeros. Portanto, quanto maior a diferença de 
energia livre de ativação entre os dois complexos enzima-substrato formados $\left(\Delta \Delta G^{\ddagger}\right)$, maior será a enantiosseletividade enzimática e maior será o excesso enantiomérico obtido.

Figura 23. Diagrama de energia de uma reação catalisada por enzima.

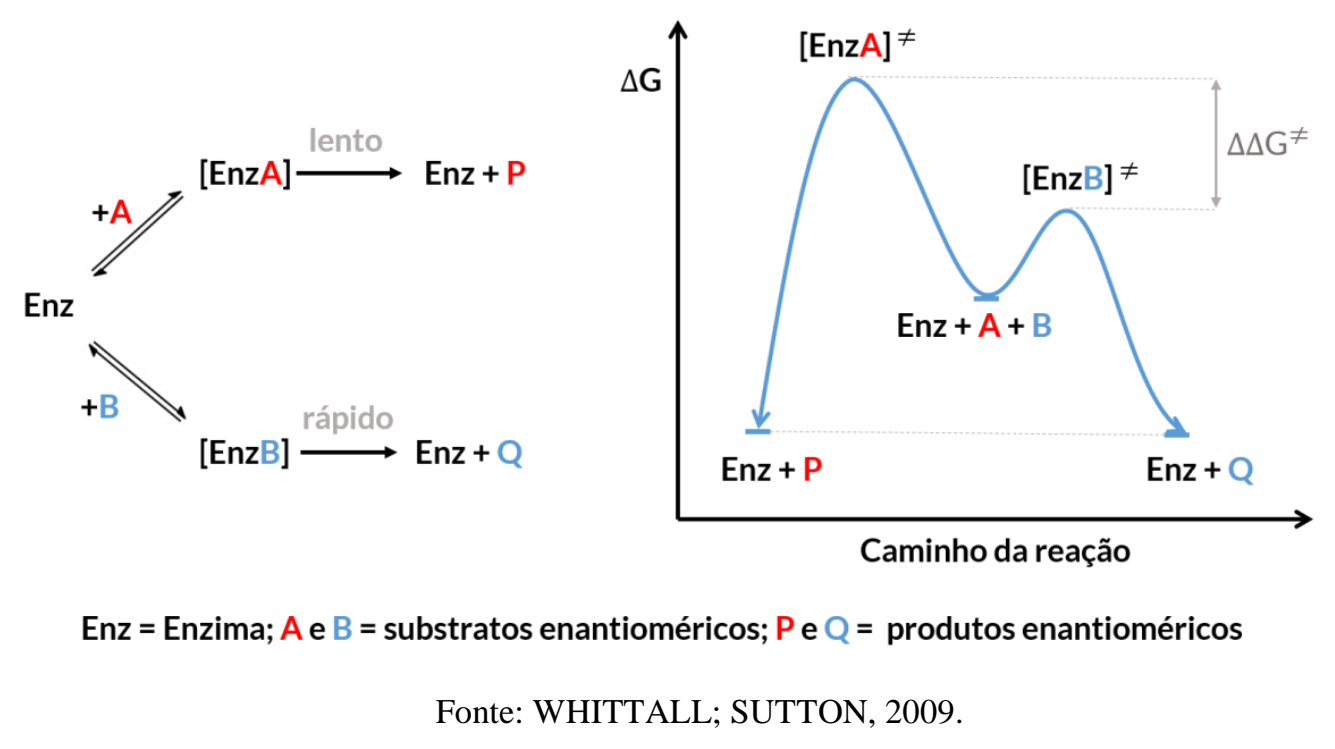

Durante a resolução cinética enzimática, as purezas enantioméricas do substrato remanescente e do produto formado variam à medida que a reação prossegue. A eficiência ou grau de seletividade na obtenção preferencial de um dos enantiômeros é conhecido como excesso enantiomérico (ee) (QAYED et al., 2015; BHARDWAJ; GUPTA, 2017).

Uma classe de moléculas em que é interessante para aplicação da resolução cinética enzimática são as haloidrinas. Haloidrinas consistem em compostos que contém grupos halogênios ligados ao carbono $\alpha$ de álcoois secundários e são comumente obtidas sinteticamente como mistura racêmica. A resolução cinética enzimática de haloidrinas utilizando lipases é uma ferramenta que possibilita a obtenção do enantiômero precursor de interesse a partir da mistura racêmica. Sendo assim, no processo de preparo e obtenção de enantiômeros biologicamente ativos, a resolução cinética se torna a etapa chave neste processo. Na resolução de compostos racêmicos, álcool (R-2-cloro-1-feniletan-1-ol) e acetato (S-acetato de 2-cloro-1-feniletan-1-ol) enantiomericamente puros podem ser obtidos através de transesterificação enzimática entre a cloridrina racêmica (R,S-2-cloro-1-feniletan-1-ol) e acetato de vinila (Figura 24) (FERREIRA, 2016; FERREIRA et al., 2017). 
Figura 24. Resolução cinética enzimática de cloridrina (R,S 2-cloro-1-feniletan-1-ol).

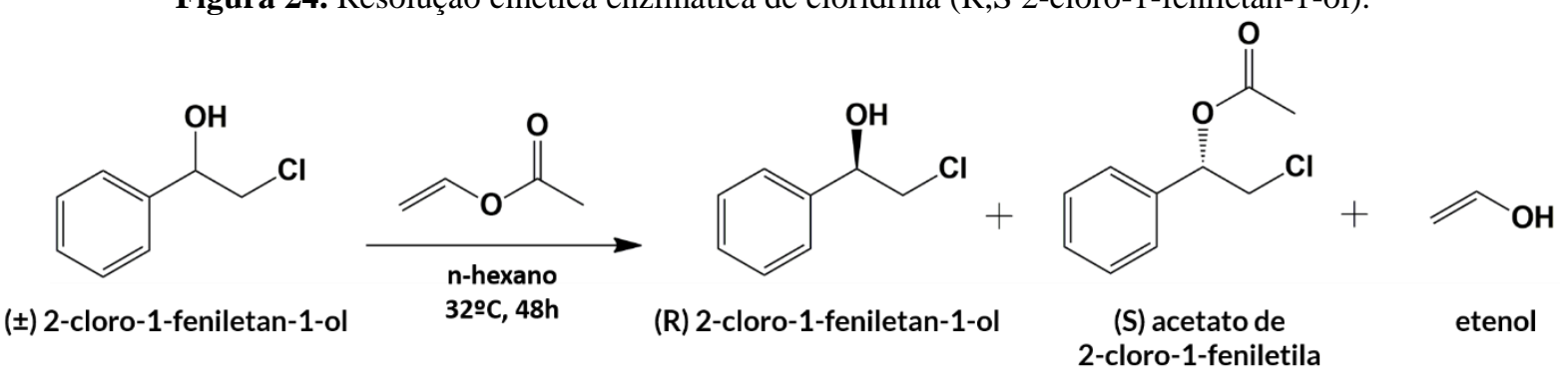

Fonte: adaptado FERREIRA et al., 2017.

O mecanismo de esterificação de álcoois na presença de um reagente doador de grupo acila ocorre em três etapas (Figura 25):

1) Inicialmente, o arranjo tridimensional dos aminoácidos pertencentes à tríade catalítica Ser-His-Asp (Serina-Histidina-Aspartato) diminui o valor do $\mathrm{pKa}$ do grupo hidroxila da serina aumentando seu caráter nucleofílico. Assim, ocorre um ataque nucleofílico do oxigênio da hidroxila serínica à carbonila do doador acila (acetato de vinila), o que leva a formação de um intermediário tetraédrico conhecido como complexo acilenzima. Este complexo é estabilizado por ligações hidrogênio com átomos de nitrogênio dos resíduos de aminoácidos próximos;

2) Em seguida, o intermediário tetraédrico se desfaz, formando o éster derivado da serina, denominado de éster acil-enzima, e liberando o álcool derivado do acetato de vinila. Neste caso, um enol é liberado, o qual se encontra em equilíbrio tautomérico com o etenal;

3) Na etapa final, o intermediário acil-enzima reage com um dos enantiômeros do álcool racêmico que é usado como substrato, levando à formação seletiva do produto acetilado e reestabelecendo a tríade catalítica. O outro enantiômero não reage ou reage mais lentamente. Em uma resolução ideal, um dos enantiometros do substrato racêmico é esterificado, enquanto o outro permanece inalterado no meio reacional. 
Figura 25. Mecanismo de esterificação enantiosseletiva de álcool secundário quiral catalisada por enzima.

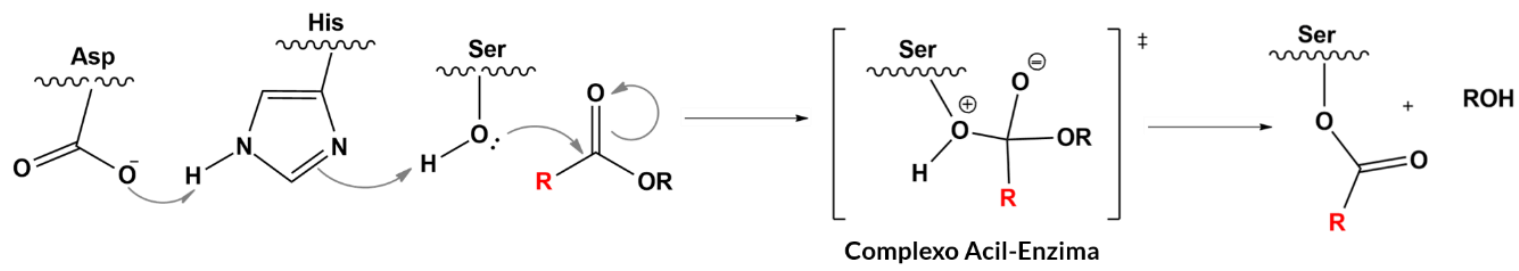

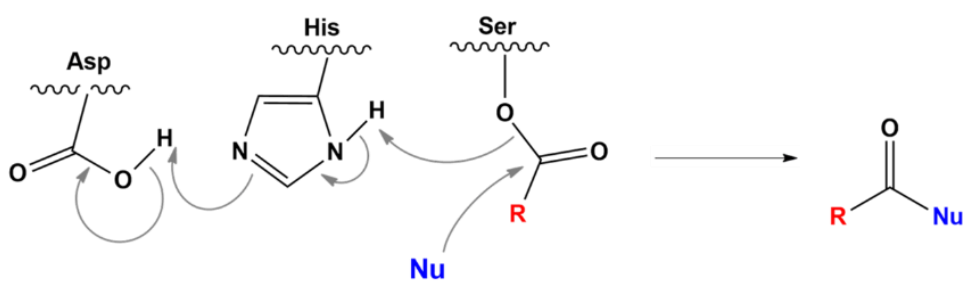

Fonte: autoria própria.

No presente estudo foi investigada a resolução cinética enzimática de cloridrinas racêmicas (R,S-2-cloro-1-feniletan-1-ol), visando obtenção de compostos enantioméricos puros usando lipase de Pseudomonas fluorescens (LPF) imobilizadas por encapsulamento em mantas e esferas de ésteres de celulose. 


\section{OBJETIVOS}

\subsection{Objetivo Geral}

Síntese de hexanoatos e benzoatos de celulose, assim como ésteres mistos, hexanoatos/benzoatos sob condições homogêneas, e com diferentes graus médios de substituição.

Obtenção de mantas constituídas por nanofibras e fibras ultrafinas via eletrofiação de soluções dos ésteres sintetizados.

Obtenção de esferas a partir dos ésteres de celulose sintetizados.

Aplicação das mantas e esferas na imobilização enzimática de lipases.

\subsection{Objetivos Específicos}

- Caracterização da celulose de linter para utilização como matéria prima;

- Caracterização dos ésteres de celulose produzidos;

- Eletrofiação de soluções dos ésteres de celulose;

- Preparação de esferas de ésteres de celulose por gotejamento;

- Imobilização de lipases de Pseudomonas fluorescens em mats e esferas;

- Aplicação da lipase imobilizada na resolução cinética de cloridrinas racêmicas. 


\section{PARTE EXPERIMENTAL}

\subsection{Materiais}

A celulose utilizada correspondeu a obtida a partir do linter de algodão, fornecida pela Nitro Química (São Paulo, SP).

$\mathrm{Na}$ execução deste trabalho foram empregados os seguintes reagentes e solventes comerciais, todos de grau analítico:

- Anidrido hexanóico (Sigma Aldrich), purificado em coluna de sílica gel 60 (0,0630,200 mm) (70-230 mesh) (Vetec), armazenado sob refrigeração em frascos âmbar com peneira molecular $4 \AA$ previamente ativada em mufla a $300^{\circ} \mathrm{C}$ por $2 \mathrm{~h}$, visando eliminação de água;

- N,N-dimetilacetamida (DMAc) (Neon), destilada na presença de $\mathrm{CaH}_{2}$ (Sigma Aldrich) e armazenada em frascos âmbar com peneira molecular $4 \AA$ previamente ativada em mufla a $300^{\circ} \mathrm{C}$ por $2 \mathrm{~h}$, visando eliminação de água (ARMAREGO; CHAI, 2009);

- Cloreto de lítio ( $\mathrm{LiCl}$ ) (Êxodo Científica), seco em estufa a vácuo a $60^{\circ} \mathrm{C}$ por um período de $12 \mathrm{~h}$, posteriormente armazenado em dessecador;

- Acetona (Êxodo Científica), ácido acético (Synth), ácido nítrico (Merck), ácido sulfúrico (Synth), brometo de potássio (Acros Organics), cloreto de benzoíla (Vetec), cloreto de magnésio (Synth), etanol (Êxodo Científica), hidróxido de sódio (Neon), metanol (Synth), peróxido de hidrogênio (Neon), tetraidrofurano (Synth), trietilamina (Sigma Aldrich) foram utilizados conforme recebidos.

\subsection{Mercerização da Celulose}

A mercerização consistiu em submeter à agitação mecânica $20 \mathrm{~g}$ de celulose em $1 \mathrm{~L}$ de solução de $\mathrm{NaOH} 20 \%$ em massa, à $0^{\circ} \mathrm{C}$ (banho de gelo), durante $1 \mathrm{~h}$. Estas condições foram estabelecidas em trabalhos prévios (RAMOS et al., 2005; ASS; BELGAGEM; FROLLINI, 2006). A celulose foi então exaustivamente lavada com água destilada até que o pH da água eliminada fosse igual ao da água de partida a fim de eliminar todo o resíduo alcalino. $\mathrm{Na}$ sequência, o material foi filtrado, sendo secado inicialmente à temperatura ambiente e depois em estufa de circulação de ar, à aproximadamente $105^{\circ} \mathrm{C}$, até massa constante. Posteriormente, 
a celulose de linter mercerizada foi triturada em moinho de micro facas Marconi modelo MA048 e armazenada em dessecador.

\subsection{Caracterização da Celulose}

\subsubsection{Espectroscopia na Região do Infravermelho}

A fim de obter espectros na região do infravermelho com transformada de Fourier (FTIR) da celulose de linter, antes e após a mercerização, foi utilizado um espectrômetro da marca modelo Tensor 27 com acessório de reflectância total atenuada (ATR), na região de 500 a $4000 \mathrm{~cm}^{-1}$ com resolução de $4 \mathrm{~cm}^{-1}$ usando 32 scans a temperatura ambiente.

\subsubsection{Grau Médio de Polimerização}

O Grau Médio de Polimerização $\left(\mathrm{GP}_{\text {visc }}\right)$ e a Massa Molar Viscosimétrica Média $\left(\mathrm{MM}_{\mathrm{visc}}\right)$ da celulose de linter e celulose mercerizada foram determinados a partir do tempo de escoamento da solução por meio do método viscosimétrico de acordo com norma da ASTM D1795-13 (AMERICAN SOCIETY FOR TESTING AND MATERIALS, 2013). Os valores de $\mathrm{MM}_{\text {visc }}$ e $\mathrm{GP}_{\text {visc }}$ obtidos pela técnica são valores médios pelo fato de as cadeias de celulose apresentarem comprimentos diferentes entre si e, portanto, tratar-se de uma mistura de macromoléculas polidispersas (KLEMM et al., 1998).

Utilizou-se um viscosímetro capilar do tipo Ostwald modelo Cannon Feske 150 (Shop $\mathrm{Lab}$ ) a $25^{\circ} \mathrm{C}$ (temperatura controlada por um banho de água e circulador termostático 2095 Masterlineт $^{\text {м }}$ Forma Scientific) (EL SEOUD et al., 2008). O solvente utilizado foi cuproetilenodiamina (CUEN) (Figura 26). Inicialmente o tempo de escoamento do solvente diluído (10 mL de CUEN em $10 \mathrm{~mL}$ de água destilada) foi determinado. Posteriormente mediuse o tempo de escoamento da solução de $3 \mathrm{mg}$ de amostra em $10 \mathrm{~mL}$ de água destilada. 
Figura 26. Reação de complexação da celulose com CUEN (cuproetilenodiamina).

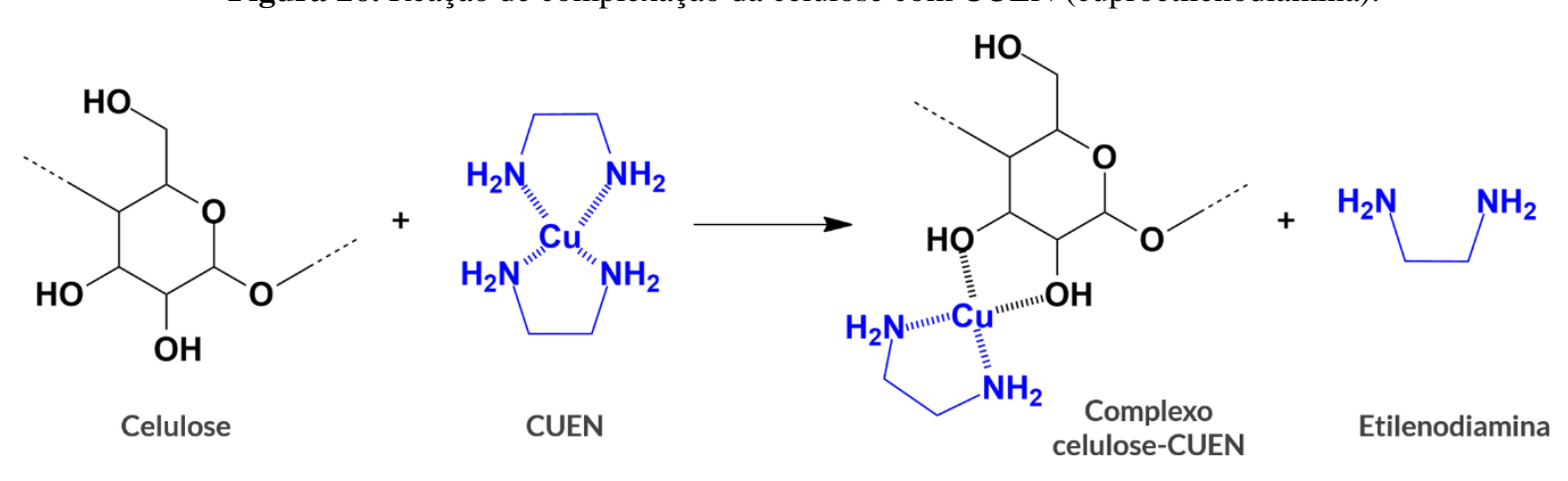

Fonte: autoria própria.

A pressão (P) que produz o fluxo é dada por:

$$
P=\rho \cdot g \cdot h
$$

Equação 1

sendo $\rho$ a densidade do líquido, $\mathrm{g}$ a aceleração da gravidade e $\mathrm{h}$ a diferença de altura da coluna do líquido.

Segundo a lei de Hagen-Poiseuille (COLLINS; BARES; BILLMEYER JUNIOR, 1973), o coeficiente de viscosidade de um líquido $(\eta)$ através do capilar pode ser expresso por:

$$
\eta=\frac{\pi \cdot r^{4} \cdot t \cdot P}{8 \cdot V \cdot l}
$$

em que P é a pressão hidrostática sobre o líquido, V é o volume do líquido, t é o tempo necessário para o líquido percorrer o capilar de raio r e comprimento 1 .

Substituindo a Equação 1 na Equação 2 e agrupando os termos, tem-se:

$$
\eta=A \cdot \rho \cdot h \cdot t
$$

Equação 3

A lei de Hagen-Pouseuille, quando aplicada a um líquido de viscosidade desconhecida e a um líquido padrão, resulta na seguinte equação que permite determinar a viscosidade relativa da solução: 


$$
\eta_{\text {rel }}=\frac{\eta}{\eta_{o}}
$$

Equação 4

sendo $\eta$ e $\eta_{\mathrm{o}}$ as viscosidades da solução e do solvente respectivamente.

Considerando-se como $\rho_{\mathrm{o}}$ a densidade do solvente e $\rho$ a densidade da solução, e substituindo a Equação 3 na Equação 4, obtém-se:

$$
\eta_{\text {rel }}=\frac{A \cdot h \cdot \rho \cdot t}{A \cdot h \cdot \rho_{o} \cdot t_{o}}=\frac{\rho \cdot t}{\rho_{o} \cdot t_{o}}
$$

Equação 5

sendo $t$ e $t_{0}$ os tempos de escoamento da solução e do solvente. Em soluções diluídas ( $\eta_{\text {rel }} \sim 1,2-$ 1,5), pode-se considerar $\rho \approx \rho_{\mathrm{o}}$. Assim, a viscosidade relativa $\left(\eta_{\text {rel }}\right)$ corresponde aproximadamente à razão entre tempo de escoamento da solução e tempo de escoamento do solvente (MANO; MENDES, 1999):

$$
\eta_{\text {rel }}=\frac{t}{t_{o}}
$$

Equação 6

O valor da viscosidade específica $\left(\eta_{\mathrm{sp}}\right)$ é calculado por:

$$
\eta_{s p}=\eta_{r e l}-1
$$

Equação 7

O valor da viscosidade intrínseca [ $\eta$ ] é calculado através da equação de Martin por meio do valor obtido para viscosidade relativa $\left(\eta_{\text {rel }}\right)$ :

$$
\log \frac{\eta_{s p}}{C}=\log [\eta]+k \cdot[\eta] \cdot C
$$

em que $\mathrm{C}$ é a concentração da solução, $\eta_{\mathrm{sp}}$ é a viscosidade específica, $\mathrm{k}$ corresponde a uma constante que para o sistema celulose/CUEN é igual a 0,13.

A partir dos valores de viscosidade intrínseca $([\eta])$ é possível determinar o grau de polimerização viscosimétrico médio ( $\mathrm{GP}_{\text {visc }}$ ) (BILLMEYER JUNIOR, 1984): 


$$
G P_{\text {visc }}{ }^{0,905}=0,75[\eta]
$$

Equação 9

A massa molar viscosimétrica média se relaciona com o grau médio de polimerização:

$$
M M_{v i s c}=162 \cdot G P_{v}
$$

Equação 10

sendo 162 a massa molar de uma unidade anidroglicosídica (UAG) em g.mol ${ }^{-1}$.

\subsubsection{Teor de $\alpha$-Celulose}

A celulose isenta de impurezas é denominada $\alpha$-celulose, sendo insolúvel em solução de $\mathrm{NaOH} 17,5 \%$. O teor de $\alpha$-celulose das amostras foi determinado por meio da norma TAPPI T $429 \mathrm{~cm}-10$ (TECHNICAL ASSOCIATION OF THE PULP AND PAPER INDUSTRY, 2010). Nesta análise, adicionou-se $10 \mathrm{~mL}$ de uma solução de hidróxido de sódio 17,5\% (em massa) a 1,0 g de celulose, a temperatura ambiente. Deixou-se em repouso por 2 min e, após esse período, a amostra foi macerada com pistilo em almofariz por 8 min. Adicionou-se mais $10 \mathrm{~mL}$ da solução alcalina, misturou-se e deixou-se em repouso por $20 \mathrm{~min}$. Em seguida, adicionou-se $40 \mathrm{~mL}$ de água destilada e filtrou-se a vácuo utilizando funil de vidro sinterizado tipo $\mathrm{C}$, previamente seco e tarado. O material retido foi lavado em $200 \mathrm{~mL}$ de ácido acético glacial diluído (20\%) e posteriormente com mais $200 \mathrm{~mL}$ de água destilada a fim de eliminar os sais da amostra. Então, secou-se o funil contendo celulose a $110^{\circ} \mathrm{C}$ em estufa de circulação de ar até obtenção de massa constante. $O$ teor de $\alpha$-celulose corresponde à massa de celulose pura na amostra, ou seja, isenta de hemicelulose (ASS; BELGAGEM; FROLLINI, 2006) e foi obtido por meio da diferença de massa das amostras antes e após o tratamento com solução de NaOH (BROWNING, 1967).

\subsubsection{Teor de Umidade}

O procedimento para determinação do teor de umidade foi baseado na norma TAPPI T 550 om-08 (TECHNICAL ASSOCIATION OF THE PULP AND PAPER INDUSTRY, 2013), e realizado em triplicata. Para cada determinação, cerca de $1,0 \mathrm{~g}$ de fibra moída foi colocada em um recipiente pesa-amostra previamente tarado, sendo o conjunto colocado em estufa de circulação de ar a $105^{\circ} \mathrm{C}$ por $4 \mathrm{~h}$. Em seguida, o recipiente com a amostra seca foi 
transferido para um dessecador para resfriamento, e então foi pesada. $\mathrm{O}$ conjunto foi levado de volta à estufa a $105^{\circ} \mathrm{C}$ por mais $1 \mathrm{~h}$, e então resfriado em dessecador e pesado. Esse processo de secagem por $1 \mathrm{~h}$, resfriamento e pesagem foi repetido até constância de massa.

\subsubsection{Teor de Cinzas}

O procedimento para determinação do teor de cinzas na fibra foi baseado na norma TAPPI T 211 om-02 (TECHNICAL ASSOCIATION OF THE PULP AND PAPER INDUSTRY, 2002), e realizado em triplicata. A determinação das cinzas é uma maneira indireta de quantificar o teor de inorgânicos (sais de $\mathrm{K}^{+}, \mathrm{Ca}^{2+}, \mathrm{Mg}^{2+} \mathrm{e} \mathrm{Si}^{4+}$ ) presentes em amostras orgânicas. Para cada determinação, um cadinho de porcelana foi previamente calcinado a $900^{\circ} \mathrm{C}$ por $4 \mathrm{~h}$, resfriado e pesado. Cerca de $1,0 \mathrm{~g}$ de celulose foi colocada no recipiente, sendo este levado a forno mufla FANEM modelo 412, seguindo a programação a seguir: (1) $105^{\circ} \mathrm{C}$, permanecendo por $10 \mathrm{~min}$; (2) $325^{\circ} \mathrm{C}$, por $1 \mathrm{~h}$; (3) $525^{\circ} \mathrm{C}$, por $4 \mathrm{~h}$. A temperatura foi aumentada lentamente, para que a amostra ficasse carbonizada sem flamejar.

\subsubsection{Análise Elementar}

A Análise Elementar foi utilizada para determinação das porcentagens de átomos de carbono $(\mathrm{C})$, hidrogênio $(\mathrm{H})$, enxofre $(\mathrm{S})$, e nitrogênio $(\mathrm{N})$ presentes, estes dois últimos último para avaliar eventual presença de impurezas e/ou contaminantes nas fibras. Para análise foi utilizado um analisador elementar ThermoScientific modelo FlashSmart por meio do método clássico de Pregl-Dumas modificado. 3,0 mg de amostra foi queimada a alta temperatura na presença de oxigênio, ocorrendo a combustão completa e liberação dos gases $\mathrm{CO}_{2}, \mathrm{H}_{2} \mathrm{O}, \mathrm{N}_{2}$ e $\mathrm{SO}_{2}$. Os mesmos são separados pela técnica de cromatografia frontal e, por meio de um detector de condutividade térmica, os teores dos elementos químicos são determinados (THOMPSON, 2008).

\subsection{7 Índice de Cristalinidade}

O Índice de Cristalinidade ( $\mathrm{I}_{\mathrm{C}}$ ) da celulose foi determinado via Difração de Raios X. Os difratogramas foram obtidos utilizando difratômetro Bruker modelo D8 Advance, equipado com um detector Lynxeye e uma fonte de radiação de cobre $(\mathrm{K} \alpha=1,5418 \AA ̊)$. As medidas foram 
realizadas no intervalo de 5 a $60^{\circ}$ com um passo de $0,02^{\circ}$ e tempo de acumulação de $0,5 \mathrm{~s}$. As amostras foram previamente secas em estufa de circulação à $105^{\circ} \mathrm{C}$ durante $2 \mathrm{~h}$.

Os planos cristalinos da unidade espacial da celulose são representados por picos de diferentes intensidades no difratograma de raios X (Figura 27). O valor do Ic foi calculado com base na área do pico correspondente ao domínio cristalino através da equação de Buschle-Diller e Zeronian (BUSCHLE-DILLER; ZERONIAN, 1992; LIU; HU, 2008; KASCHUK et al., 2017):

$$
I_{C}=1-\frac{I_{1}}{I_{2}}
$$

sendo $\mathrm{I}_{1}$ é o valor de difração da linha de base referente à parte não cristalina da celulose $\left(18^{\circ}\right.$ para celulose $\mathrm{I}, 16^{\circ}$ para celulose II), e $\mathrm{I}_{2}$ é o valor do pico de difração relativo à parte cristalina $\left(22^{\circ} \leq 2 \theta \leq 23^{\circ}\right.$ para celulose I, $18^{\circ} \leq 2 \theta \leq 22^{\circ}$ para celulose II) (FRENCH; SANTIAGO CINTRÓN, 2013; KASCHUK; FROLLINI, 2018).

A Equação 11 baseia-se no método Segal (SEGAL et al., 1959). Estudos teóricos e experimentais desenvolvidos recomendam a aplicação do mesmo quando os picos característicos da celulose I e II são bem definidos (FRENCH; SANTIAGO CINTRÓN, 2013; NAM et al., 2016; KASCHUK; FROLLINI, 2018) (FRENCH; SANTIAGO CINTRÓN, 2013; FRENCH, 2014; NAM et al., 2016). Nestes estudos, o valor do grau $2 \theta$ para a região não cristalina da celulose I foi corrigido (de $13^{\circ} \leq 2 \theta \leq 15^{\circ}$ para $16^{\circ}$ ) sendo esta correção considerada no presente estudo.

Outro método utilizado para determinação do índice de cristalinidade da celulose por meio da por diferença de área (RULAND, 1961; VONK, 1972). A determinação do $I_{C}$ foi baseada no método de Ruland-Vonk por meio da integração dos picos cristalinos e banda não cristalina (RULAND, 1961) conforme descrito na Equação 12:

$$
I_{C}=\frac{I_{c r}}{I_{c r}+I_{n c}}
$$

Sendo $\mathrm{I}_{\mathrm{cr}}$ a integração dos picos cristalinos de difração e $\mathrm{I}_{\mathrm{nc}}$ a integração da banda não cristalina (TERINTE; IBBETT; SCHUSTER, 2011). 
Figura 27. Padrão de difração de raios $X$ típico de fibras de algodão.

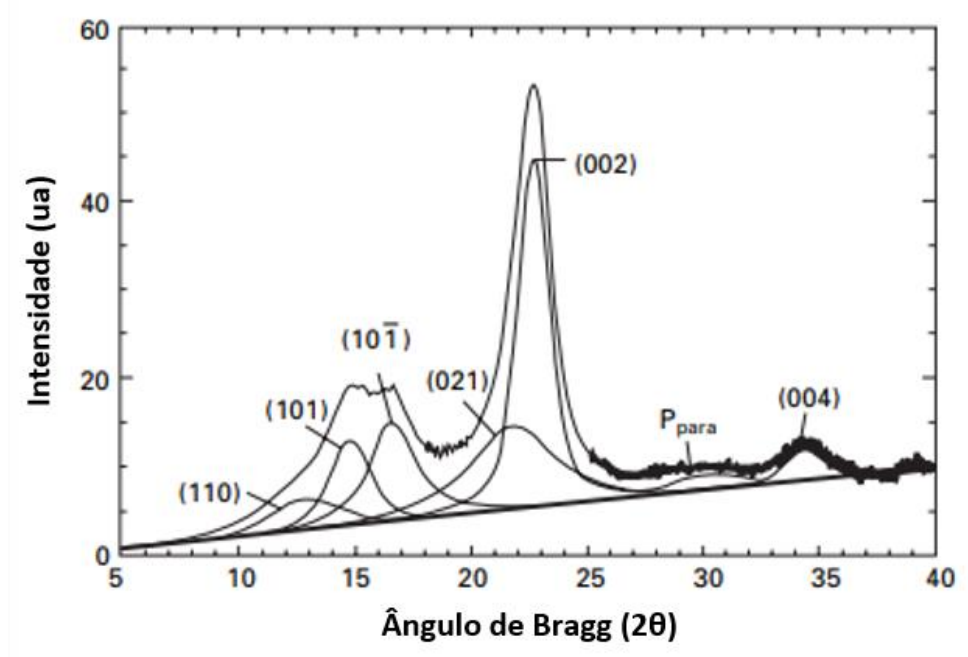

Fonte: adaptado GORDON; HSIEH, 2007.

Além disso, por meio da difração de raios X é possível determinar a dimensão média dos domínios cristalinos das amostras. Quando esses cristais são menores que $0,1 \mu \mathrm{m}$, o tamanho médio deles $(\mathrm{t})$ pode ser determinado pela equação de Scherrer (CULLITY; STOCK, 2014):

$$
t=\frac{K \cdot \lambda}{\mathrm{B} \cdot \cos \theta}
$$

sendo B o alargamento da linha de difração medida à meia altura de sua intensidade máxima (medida em radianos) e $\mathrm{K}$ representa a constante de proporcionalidade.

A constante de proporcionalidade $\mathrm{K}$ é função da forma geométrica do domínio cristalino. Para medidas de largura do pico a meia altura, $\mathrm{K}$ atinge valores entre 0,84 e 0,89 dependendo da geometria. No caso, admitiu-se uma geometria esférica com valor de 0,9 (CULLITY; STOCK, 2014).

\subsubsection{Microscopia Eletrônica de Varredura}

A estrutura supramolecular das amostras foi avaliada por meio da Microscopia Eletrônica de Varredura (MEV). Utilizou-se um microscópio LEO 440 ZEISS operando a 20 $\mathrm{kV}$ usando elétrons secundário (SE1) atingindo uma resolução de $11 \mathrm{~mm}$. As amostras foram colocadas sobre uma fita adesiva de carbono em porta-amostras de alumínio, recobertas com 
uma fina camada de ouro (material condutor), utilizando-se para o recobrimento o equipamento Coating System MED 020 BAL-TEC. Foram analisadas as superfícies das amostras de celulose de linter antes e após o tratamento de mercerização.

\subsubsection{Comprimento e Espessura Médios}

A fim de se avaliar o comprimento e espessura médios das fibras de celulose de linter antes e após a mercerização, utilizou-se o equipamento MorFi Compact (Techpap) o qual detecta fibras até escala micrométrica. Assim, as fibras foram suspensas em água $\left(\sim 0,5 \mathrm{~g} . \mathrm{L}^{-1}\right)$ e analisadas usando o equipamento que apresenta alta resolução em sua análise de fibras em geral. Os limites de detecção para a técnica de MorFi são [5-50] $\mu$ m para a espessura e [101000] $\mu \mathrm{m}$ para o comprimento, de modo que qualquer fibra que não apresente algum destes valores de espessura e comprimento não será detectada nas análises.

\subsubsection{Análise Termogravimétrica}

A perda de massa das amostras em função da temperatura foi avaliada via análise termogravimétrica realizada em Analisador Termogravimétrico Shimadzu TGA-50. Foram pesadas aproximadamente $8,0 \mathrm{mg}$ de amostra em um porta-amostra de platina sendo a análise realizada em atmosfera de nitrogênio com fluxo de $50 \mathrm{~mL} \cdot \mathrm{min}^{-1}$, na faixa de temperatura de 25 a $800^{\circ} \mathrm{C}$, a uma razão de aquecimento de $20^{\circ} \mathrm{C} \cdot \mathrm{min}^{-1}$.

\subsection{Dissolução em Sistema LiCl/DMAc}

A etapa da dissolução da celulose, assim como as etapas de esterificação, foram realizadas em sistema composto por balão de quatro bocas equipado com: um agitador mecânico; um condensador de refluxo com a saída tampada; um funil de adição (sem braço lateral de equalização) e uma torneira com três saídas visando a conexão à bomba de vácuo e ao fluxo de nitrogênio seco (Figura 28). Foram adicionadas ao balão $2,0 \mathrm{~g}$ de celulose mercerizada (previamente seca em estufa de circulação de ar a $105^{\circ} \mathrm{C}$ por $4 \mathrm{~h}$ ) e $5,0 \mathrm{~g}$ de cloreto de lítio (previamente seco em estufa a vácuo a $60^{\circ} \mathrm{C}$ por $12 \mathrm{~h}$ ).

A presença de água residual leva a vários efeitos prejudiciais: afeta a solubilidade do LiCl em DMAc; diminui a solubilidade da celulose no solvente; aumenta a agregação de 
celulose dissolvida e consome agentes de derivatização (POTTHAST et al., 2002; KOSTAG et al., 2019).

O sistema foi imerso em banho de óleo (canola) com controlador digital de temperatura e tempo, sendo a pressão no balão reduzida a $2 \mathrm{mmHg}$ e a temperatura do óleo elevada até $110^{\circ} \mathrm{C}$. Após permanecer nesta temperatura por $30 \mathrm{~min}$, o sistema foi isolado da bomba de vácuo, conservando-se a pressão interna reduzida. Adicionou-se $100 \mathrm{~mL}$ de DMAc em refluxo, ainda sob pressão reduzida mantendo a tampa do funil de adição fechada. $O$ sistema foi conectado a uma linha de nitrogênio seco, e após a equalização da pressão interna com $\mathrm{N}_{2}$, a tampa do condensador foi substituída por um tubo secante. O sistema foi aquecido a $160^{\circ} \mathrm{C}$ sob intensa agitação por 90 min. Após este período, o sistema foi resfriado lentamente, mantendose a agitação por um período de $24 \mathrm{~h}$.

Figura 28. Representação das etapas do processo de dissolução da celulose.
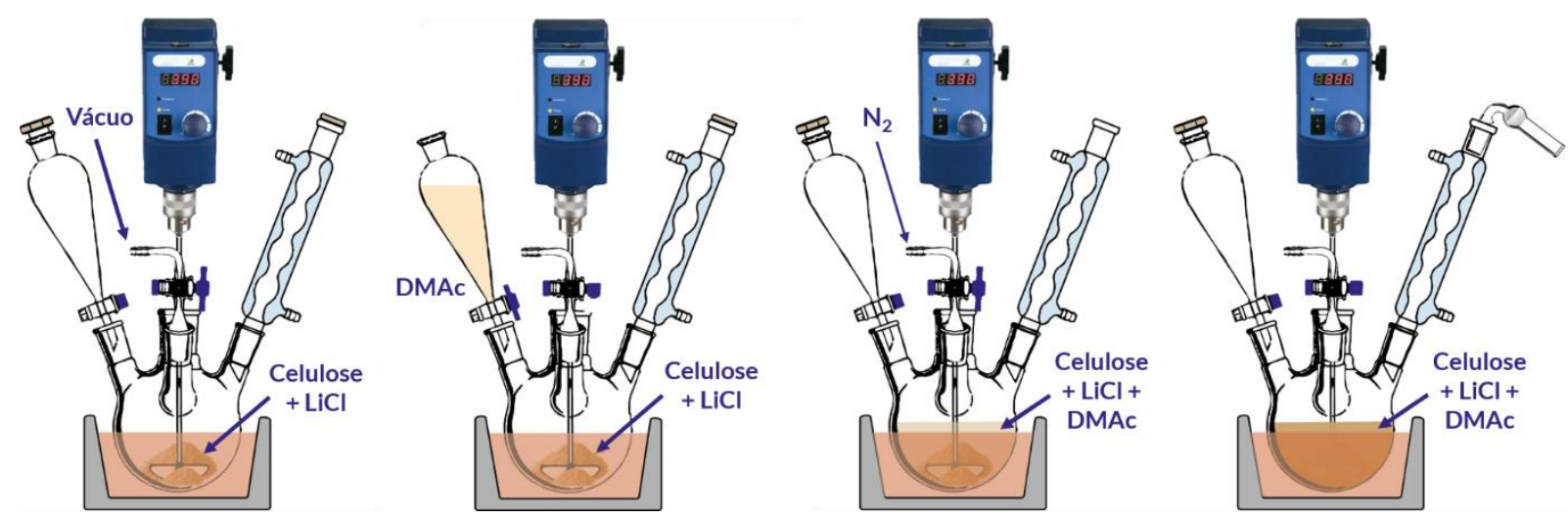

Fonte: Autoria própria.

A etapa de dissolução da celulose seguiu procedimentos estabelecidos em estudos anteriores (RAMOS et al., 2011a, 2011b; ALMEIDA et al., 2013).

\subsection{Derivatização da Celulose}

A solução de celulose foi aquecida até $110^{\circ} \mathrm{C}$ e o reagente esterificante desejado foi adicionado, em diferentes razões molares ( $\mathrm{Mol}_{\mathrm{ag}}$. esterificante/ $\mathrm{Mol} \mathrm{OH}_{\mathrm{OH}} \mathrm{UAG}$ ) visando-se obter ésteres com GS específicos (Figura 29). 
Figura 29. Representação das etapas do processo de derivatização da celulose.

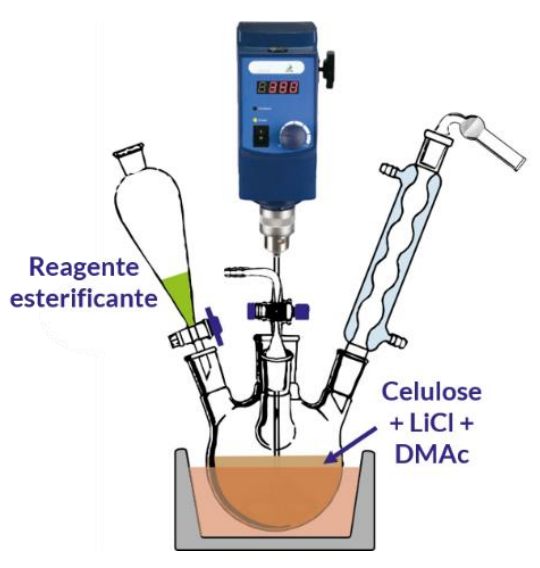

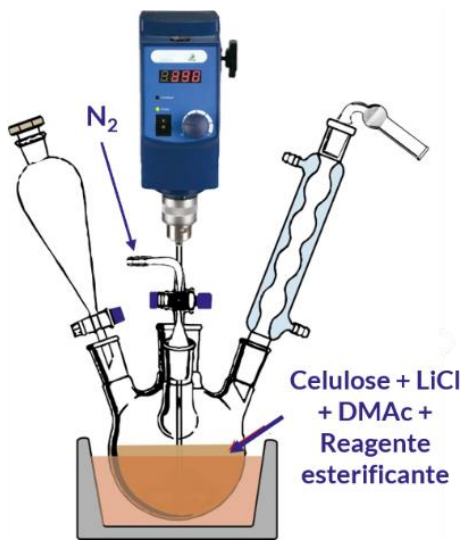

Fonte: Autoria própria.

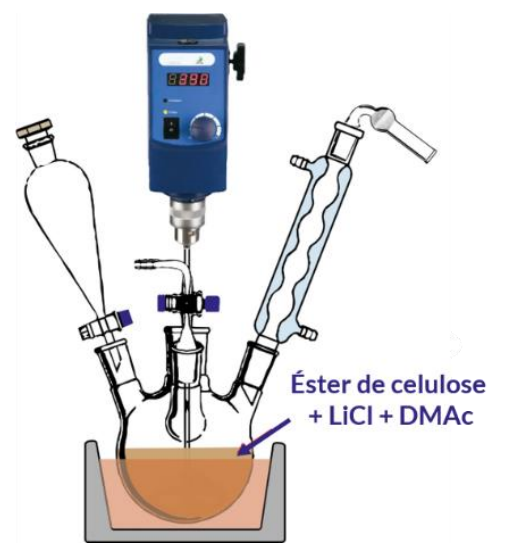

$\mathrm{O}$ sistema permaneceu sob agitação mecânica e refluxo, na presença de $\mathrm{N}_{2}$ seco. $\mathrm{O}$ produto final foi resfriado à temperatura ambiente, adicionando metanol posteriormente a fim de precipitar o éster de celulose formado, o qual foi isolado após filtração a vácuo, sendo o precipitado em metanol. Visando eliminar o solvente LiCl/DMAc e os agentes esterificantes residuais, os ésteres de celulose foram exaustivamente lavados com metanol e água. Após a purificação, os mesmos foram secos em estufa de circulação de ar, a $110^{\circ} \mathrm{C}$, até massa constante, e posteriormente, foram submetidos a um processo de moagem criogênica em moinho vibratório Retsch modelo MM400.

As condições experimentais utilizadas e os respectivos códigos dos produtos obtidos estão descritas na Tabela 1.

Tabela 1. Condições experimentais utilizadas.

\begin{tabular}{|c|c|c|c|}
\hline Amostra & $\begin{array}{l}\text { Mol }_{\text {ag. esterificante/ }} \\
\text { MoloH da UAG }\end{array}$ & Reagente & Código \\
\hline \multirow{3}{*}{$\begin{array}{l}\text { Hexanoato de } \\
\text { celulose }\end{array}$} & 3 & Anidrido hexanóico & Hex 3 \\
\hline & 6 & Anidrido hexanóico & Hex 6 \\
\hline & 12 & Anidrido hexanóico & Hex 12 \\
\hline \multirow{3}{*}{$\begin{array}{l}\text { Benzoato de } \\
\text { celulose }\end{array}$} & 3 & Cloreto de benzoíla & Benz 3 \\
\hline & 6 & Cloreto de benzoíla & Benz 6 \\
\hline & 12 & Cloreto de benzoíla & Benz 12 \\
\hline \multirow{2}{*}{$\begin{array}{l}\text { Hexanoato } \\
\text { Benzoato de } \\
\text { celulose }\end{array}$} & $3(1,5: 1,5)$ & \multirow{2}{*}{$\begin{array}{l}\text { Anidrido hexanóico + cloreto de } \\
\text { benzoíla + trietilamina }\end{array}$} & HexBenz 3 \\
\hline & $6(3: 3)$ & & HexBenz 6 \\
\hline
\end{tabular}


As razões molares selecionadas foram 3, 6 e 12 visando obter ésteres de celulose com 1, 2 e 3 graus médios de substituição. Deve-se salientar a possibilidade de ocorrer agregação das cadeias de celulose em solução, o que dificulta a utilização de reagentes em condições estequiométricas e a completa homogeneidade e uniformidade da distribuição dos substituintes ao longo da cadeia (RAMOS, 2005; RODRIGUES, 2014).

\subsection{Caracterização dos Ésteres Produzidos}

\subsubsection{Espectroscopia na Região do Infravermelho}

Os ésteres de celulose foram avaliados via espectroscopia da região do infravermelho de forma semelhante ao descrito anteriormente para a celulose (seção 3.3.1).

\subsubsection{Análise Elementar}

A composição em porcentagem dos elementos carbono (C), hidrogênio (H) e nitrogênio $(\mathrm{N})$ presentes nas amostras de ésteres de celulose foi avaliada por meio da análise elementar semelhante ao descrito anteriormente (seção 3.3.6).

\subsubsection{Espectroscopia de Absorção Atômica (Lítio)}

Os ésteres de celulose foram caracterizados por espectroscopia de absorção atômica visando verificar o eventual conteúdo residual de lítio presente nas amostras, avaliando, portanto, a eficiência do processo de purificação.

Para a análise foi utilizado um espectrômetro de absorção atômica Perkin Elmer modelo PINAACLE 900T modo chama (AA) num comprimento de onda de $670 \mathrm{~cm}^{-1}$. Uma curva de padronização analítica foi preparada com concentrações de 100 a 500 ppb de lítio e o coeficiente de correlação linear obtido foi 0,9995 .

Para a abertura das amostras, adicionou-se 4,0 mg de amostra e $1 \mathrm{~mL}$ de ácido sulfúrico concentrado em um erlenmeyer de $50 \mathrm{~mL}$. Aqueceu-se agitando manualmente até que a amostra apresentasse coloração escura devido a oxidação. Em seguida foi adicionado peróxido de hidrogênio 30\% com uma pipeta de Pasteur até obter-se uma solução incolor. Aqueceu-se a solução a fim de retirar o excesso de peróxido de hidrogênio. A solução foi resfriada, posteriormente adicionou-se $30 \mathrm{~mL}$ de solução de ácido nítrico $2 \%$. Transferiu-se para um balão 
volumétrico de $25 \mathrm{~mL}$ completando com a solução de ácido nítrico. Toda a vidraria utilizada para o preparo das amostras foi lavada com água mili-Q, solução de ácido nítrico $10 \%$ e solução de $\mathrm{KCl} 2 \mathrm{ppm}$. As soluções foram preparadas com água mili-Q (condutividade 18,2 M $\Omega . \mathrm{cm}^{-1}$ ).

\subsection{4 Índice de Cristalinidade}

Os IC dos ésteres de celulose foram determinados via Difração de raios $\mathrm{X}$ de forma semelhante ao descrito anteriormente (seção 3.3.7).

\subsubsection{Análise Termogravimétrica}

A avaliação das propriedades térmicas dos ésteres de celulose foi realizada de modo semelhante ao descrito anteriormente (seção 3.3.10).

\subsubsection{Grau Médio de Substituição}

\subsubsection{Espectroscopia de Ressonância Magnética Nuclear}

Os graus médios de substituição (GS) dos ésteres de celulose obtidos por meio de reação de esterificação da celulose com um anidrido de ácido foram determinados por espectroscopia de Ressonância Magnética Nuclear de Prótons (RMN- $\left.{ }^{1} \mathrm{H}\right)$. Utilizou-se um espectrômetro Agilent Technologies modelo 500/54 Premium Shielded operado a 500MHz e 392 pulsos. A concentração das amostras foi de $10 \mathrm{mg} \cdot \mathrm{mL}^{-1}$, em DMSO-d 6 , e as análises foram feitas a $80^{\circ} \mathrm{C}$. Ácido trifluoroacético (TFA) foi adicionado às amostras para promover o deslocamento do pico de ressonância da água residual e prótons hidroxílicos para fora da região espectral de interesse.

Por meio da ressonância magnética nuclear os valores de GS foram calculados pela relação das integrais dos picos relativos à ressonância dos prótons do grupo alquila ligados às carbonilas (1,7 a 2,5 ppm) e a dos prótons dos anéis de glicose (2,7 a 5,5 ppm).

Para hexanoatos de celulose, o GS foi calculado segundo a equação (GOODLETT; DOUGHERTY; PATTON, 1971; ASS; BELGAGEM; FROLLINI, 2006):

$$
G S=\frac{7 \times I_{\text {H metila }}}{3 \times I_{H U A G}}
$$


sendo $\mathrm{I}_{\mathrm{H} \text { metila }}$ a integral dos picos de ressonância dos prótons metílicos dos substituintes

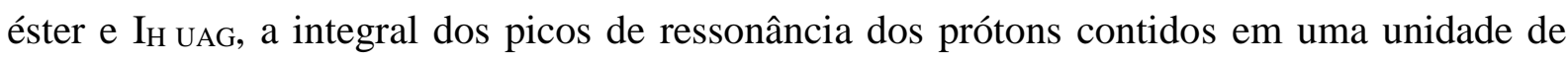
anidroglicose (UAG).

O GS dos benzoatos de celulose foi calculado a partir dos espectros de $\mathrm{RMN}-{ }^{1} \mathrm{H}$ por meio das integrais relativos à ressonância dos prótons do grupo fenila (7,5 a 8,5 ppm) e a dos prótons dos anéis de glicose (2,7 a 5,5 ppm) utilizando a seguinte equação (GOODLETT; DOUGHERTY; PATTON, 1971; ZHANG et al., 2009):

$$
G S=\frac{7 \times I_{H \text { fenila }}}{5 \times I_{H U A G}}
$$

sendo $I_{H}$ fenila a integral dos picos de ressonância dos prótons fenílicos e $I_{H}$ UAG, a integral dos picos de ressonância dos prótons da unidade de uma anidroglicose.

O grau médio de substituição dos ésteres mistos foi calculado individualmente para cada éster por meio da Equação 14 para hexanoato e da Equação 15 para benzoato.

O grau médio de substituição (GS) de ésteres de celulose é um indicativo do número médio de substituintes introduzidos por unidade de anidroglicose (UAG). A molécula de celulose possui três sítios reativos que correspondem aos grupos hidroxila ligados aos carbonos $\mathrm{C}_{(2)}, \mathrm{C}_{(3)}$ e $\mathrm{C}_{(6)}$. Assim, o GS máximo da celulose é igual a 3. Dizer, por exemplo, que um acetato de celulose possui um GS 1,0 significa que, em média, apenas um dos grupos hidroxilas da unidade UAG foi substituído por um grupo acetila $\left(\mathrm{CH}_{3} \mathrm{COO}-\right)$, já um acetato cujo GS é igual a 3,0 representa que todas as hidroxilas do anel foram substituídas por $\mathrm{CH}_{3} \mathrm{COO}$ -

\subsection{Modelação dos Ésteres}

Aplicações de derivados de celulose requerem atribuir alguma modelação aos mesmos, usando processamentos específicos para formação de filmes, membranas, esferas, fibras. No presente estudo, as modelações selecionadas para os ésteres de celulose foram a conformação em esferas por gotejamento de solução, e também como mantas não tecidas constituídas por fibras, via eletrofiação. 


\subsubsection{Preparação de Mantas Não Tecidas via Eletrofiação}

Mantas não tecidas, (mats) foram preparados via eletrofiação de soluções dos ésteres de celulose sintetizados, usando THF/DMAc na proporção 65:35 (FERRACINI, 2017) como solvente via agitação magnética à temperatura ambiente. Para a eletrofiação, foi utilizado um aparato de eletrofiação da IME Technologies (Geldrop, Holanda). A concentração de éster utilizada foi 7, 9, 11 e 13\% em massa e o tempo de dissolução foi aproximadamente $12 \mathrm{~h}$. As soluções foram acondicionadas em seringas de $1 \mathrm{~mL}$ (SOLIDOR, diâmetro: 0,45 mm e comprimento 12,7 mm), adicionadas em tubos capilares (diâmetro interno: 1,00 mm e diâmetro externo: 1,6 mm), conectados a uma bomba (IME Technologies modelo NE-1000) para o controle da razão de fluxo do solvente. As agulhas utilizadas (INJEX modelo 27G1") apresentam diâmetro interno de $0,40 \mathrm{~mm}$ e comprimento $25 \mathrm{~mm}$. A voltagem utilizada $(10,15$, 20 e $25 \mathrm{kV}$ ) e os outros parâmetros do processo de eletrofiação, como distância suporte de agulha-coletor $(5,10,15$ e $25 \mathrm{~cm})$ e fluxo do solvente $\left(5,5,15,5\right.$ e 45,5 $\left.\mu \mathrm{L} \cdot \mathrm{min}^{-1}\right)$, foram otimizados via testes. Os coletores de fibras utilizados foram chapas delgadas de vidro com 6 cm de diâmetro e 0,2 mm de espessura acopladas ao contra-eletrodo (coletor estático) (GREISH et al., 2010; RODRIGUES et al., 2015).

\subsubsection{Caracterização das Mantas}

Os ésteres de celulose foram avaliados via Microscopia Eletrônica de Varredura (MEV) semelhante ao descrito anteriormente para a celulose (seção 3.3.8). O diâmetro médio das fibras foi determinado por meio do software Fiji (ImageJ) (SCHINDELIN et al., 2012; SCHNEIDER; RASBAND; ELICEIRI, 2012) utilizando as micrografias obtidas no MEV.

\subsubsection{2 Ângulo de Contato}

A molhabilidade é um parâmetro que fornece informações sobre as propriedades de superfície (caráter hidrofílico e hidrofóbico) e pode ser determinada pela medição do ângulo de contato entre a superfície do material com uma gota de água.

O ângulo de contato dinâmico entre uma gota de água deionizada e a superfície dos mats foi medido segundo a norma TAPPI T 558 om-97 (TECHNICAL ASSOCIATION OF THE PULP AND PAPER INDUSTRY, 1997). O equipamento utilizado foi KSV modelo CAM 2008 com câmera e sistema de gravação do Instituto de Física de São Carlos (IFSC-USP). Uma 
gota de água deionizada ( $4 \mu \mathrm{L})$ foi depositada sobre a superfície de cada mat e a variação do ângulo de contato foi calculada a partir de 300 medidas realizada utilizando três regiões diferentes (BERRY et al., 2015).

Quando um líquido é colocado sobre uma superfície sólida plana e horizontal, o desbalanceamento das forças interfaciais entre líquido, ar e sólido podem levar a formação de uma gota (Figura 30). O ângulo de contato formado na interface pode ser relacionado a energias de superfície considerando as três interfaces através da equação de Young (TZE; GARDNER, 2001):

$$
\cos \theta=\frac{\gamma_{s v}-\gamma_{s l}}{\gamma_{l v}}
$$

Equação 16

Sendo: $\gamma_{\mathrm{sv}}$ relacionado a interface sólido-vapor; $\gamma_{\mathrm{sl}}$ relacionado a interface sólidolíquido e $\gamma_{1 v}$ tensão de superfície do líquido (Figura 30).

Figura 30. Representação vetorial do ângulo de contato como medida de "molhabilidade" de um sólido por um líquido.

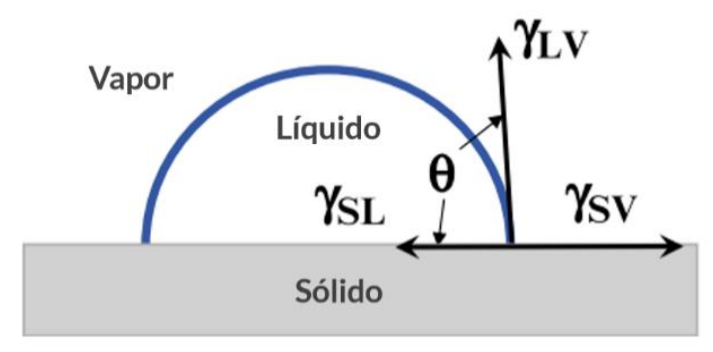

Fonte: LAW; ZHAO, 2016.

Como o formato da gota resulta das interações favoráveis ou desfavoráveis do líquidosólido, a magnitude do ângulo de contato pode ser usada para avaliar essas interações. Quando:

- $0^{\circ}<\theta<90^{\circ}$, a interação é favorecida (YUAN; LEE, 2013) e o líquido "molha" a superfície sólida, mas não completamente;

- $90^{\circ}<\theta<180^{\circ}$, a interação é desfavorecida (YUAN; LEE, 2013) e o líquido não "molha" a superfície sólida o que é favorecido por líquidos de alta tensão superficial em sólidos de baixa energia de superfície.

Assim, através do ângulo $\theta$ medido, e do conhecimento de propriedades do líquido utilizado (água), se tem informações sobre propriedades da superfície. 


\subsubsection{Preparação de Esferas}

Para a preparação de esferas de ésteres de celulose foi empregada a técnica de gotejamento. Os ésteres foram dissolvidos em acetona (5\%) por agitação a temperatura ambiente. A solução foi gotejada sobre nitrogênio líquido com uma pipeta Pasteur de $3 \mathrm{~mL}$ descartável. Após congeladas, as esferas foram vertidas sobre água e metanol a fim de descongelar. Posteriormente as esferas foram secas a temperatura ambiente por um período de 48h e armazenadas em dessecador.

\subsubsection{Caracterização das Esferas}

A formação de esferas foi confirmada por Microscopia Eletrônica de Varredura (MEV). Utilizou-se um microscópio LEO 440 ZEISS operando a $20 \mathrm{kV}$ usando elétrons secundário (SE1) atingindo uma resolução de $11 \mathrm{~mm}$. As amostras foram colocadas sobre uma fita adesiva de carbono em porta-amostras de alumínio, recobertas com uma fina camada de ouro (material condutor), utilizando-se para o recobrimento o equipamento Coating System MED 020 BAL-TEC. O diâmetro médio foi determinado utilizando um paquímetro digital. A medida de rugosidade média e área superficial foi determinada por meio do software Fiji (ImageJ) utilizando o plugin SurfCharJ (CHINGA et al., 2007).

\subsection{Imobilização Enzimática}

\subsubsection{Imobilização de Lipases em Mantas}

Lipase de Pseudomona fluorescens foi imobilizada em mantas eletrofiadas a partir de soluções de éster de celulose. Soluções de Hex 6 (330 mg) e lipase de Pseudomona fluorescens (50 e $100 \mathrm{mg}$ ) em $3 \mathrm{~mL}$ de THF/DMAc na proporção 65:35 foram preparadas sob agitação magnética à temperatura ambiente. O tempo de dissolução foi aproximadamente $12 \mathrm{~h}$.

Benzoatos e hexanoatos-benzoatos de celulose não foram considerados para imobilização de lipases, pois como será discutido posteriormente, o solvente que se mostrou adequado para preparação de mats a partir de soluções desses ésteres foi o ácido trifluoroacético, o qual causaria degradação na lipase com perda de atividade. 
A partir dos resultados obtidos na caracterização dos mats eletrofiados (seção 3.7.1.1) selecionou-se as seguintes condições para a eletrofiação das soluções contendo enzimas: distância de $10 \mathrm{~cm}$ entre agulha-coletor, tensão de $25 \mathrm{kV}$ aplicada e fluxo de injeção de solução de $15,5 \mu \mathrm{L} \cdot \mathrm{min}^{-1}$. Posteriormente os mats foram secos a temperatura ambiente por um período de $48 h$.

\subsubsection{Imobilização de Lipases em Esferas}

Lipases de Pseudomona fluorescens foram imobilizadas em esferas por encapsulamento empregando a técnica de gotejamento. Ésteres de celulose do tipo Hex 6 e Hex 12 (330 mg) e lipase (50 e $100 \mathrm{mg}$ ) foram dissolvidos em $3 \mathrm{~mL}$ acetona por agitação magnética a temperatura ambiente. A solução foi gotejada sobre nitrogênio líquido com uma pipeta Pasteur de $3 \mathrm{~mL}$ descartável. Após congeladas, as esferas foram vertidas sobre água ou metanol a fim de descongelar. Posteriormente as esferas foram secas a temperatura ambiente por um período de $48 h$.

\subsection{Biocatálise na Reação de Resolução Cinética de Cloridrina Racêmica}

A reação de resolução cinética enzimática foi realizada em frasco de penicilina de 10 $\mathrm{mL}$. Foram adicionados $15,7 \mathrm{mg}$ de cloridrina racêmica (R,S-2-cloro-1-feniletan-1-ol), $25 \mathrm{mg}$ de lipase Pseudomonas fluorescens (LPF) imobilizadas em éster de celulose, 3,0 mL de nhexano e $45 \mu \mathrm{L}$ de agente acetilante (acetato de vinila) (ROCHA et al., 2010; RIBEIRO; RAMINELLI; PORTO, 2013). As lipases foram imobilizadas em esferas de Hex 6 (15 e 30\% de LPF) em água e metanol, Hex 12 (15\% de LPF) em água; e mats de Hex 6 (15 e 30\% de LPF). O acetato de vinila tem a função de reagir com a S-cloridrina (S-2-cloro-1-feniletan-1ol) formando S-acetato de 2-cloro-1-feniletan-1-ol, assim separando o enantiômero Rcloridrina (R-2-cloro-1-feniletan-1-ol) (Figura 31). Os frascos foram fechados com septos de borracha, vedados com fita teflon e mantido em agitação magnética a $130 \mathrm{rpm}$, temperatura de $32^{\circ} \mathrm{C}$ por $48 \mathrm{~h}$. 
Figura 31. Resolução cinética enzimática de cloridrina (R,S 2-cloro-1-feniletan-1-ol).

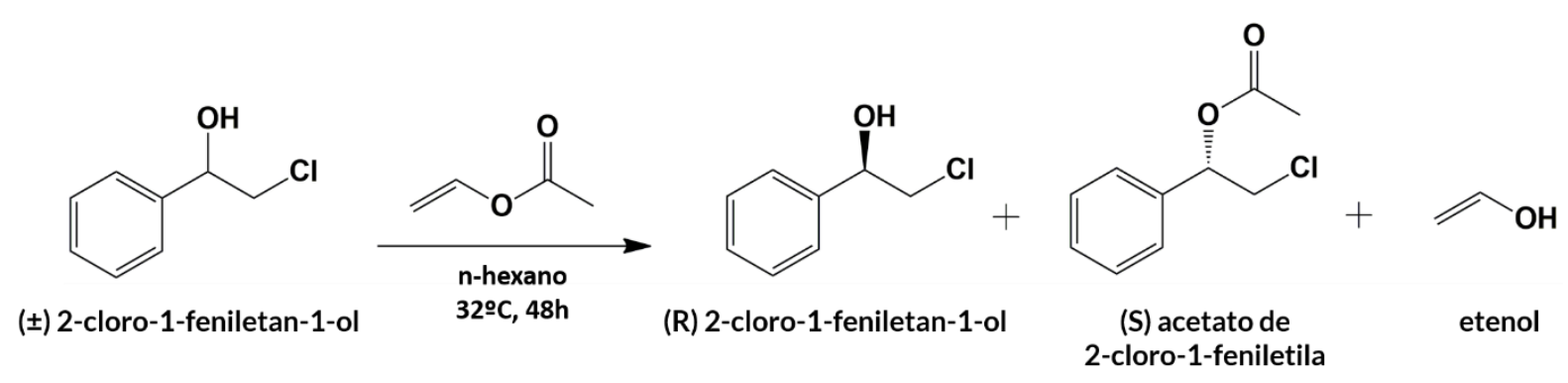

Fonte: adaptado FERREIRA et al., 2017.

O processo foi monitorado a cada $24 \mathrm{~h}$ coletando-se $0,1 \mathrm{~mL}$ do meio reacional e transferindo para os frascos vial de 1,5 mL. O volume do frasco vial foi completado com acetato de etila e o conteúdo analisado por Cromatógrafo a Gás acoplado a um detector de ionização de chama (CG-DIC) para a determinação dos seguintes parâmetros das reações: percentual de conversão dos reagentes em produtos $(\% c)$, razão enantiomérica $(E)$, excesso enantionérico $(e e)$.

Foi utilizado um Cromatógrafo a Gás da marca Shimadzu modelo GC 2010, equipado com auto-injetor AOC 20i, um detector de ionização de chama (DIC) e uma coluna quiral CPChiralsil-DEX CB ( $\beta$-ciclodextrina) $25,0 \mathrm{~m}$ x 0,25 $\mathrm{mm}$ x 0,25 $\mu \mathrm{m}$. O gás de arraste utilizado foi nitrogênio. As análises foram efetuadas no Laboratório de Química Orgânica e Biocatálise (IQSC-USP). As condições cromatográficas foram: volume de injeção 1,0 $\mu \mathrm{L}$; temperatura de injeção $250^{\circ} \mathrm{C}$, modo de injeção split, razão split 1:10, gás carreador: $\mathrm{N}_{2}$, modo de controle de fluxo: pressão, pressão: 69,0 kPa, fluxo total: $11,1 \mathrm{~mL} \cdot \mathrm{min}^{-1}$, fluxo na coluna $0,73 \mathrm{~mL} \cdot \mathrm{min}^{-1}$, velocidade linear 24,1 cm.s $\mathrm{s}^{-1}$, fluxo de purga 3,0 mL.min ${ }^{-1}$, coluna quiral Cp-Chirasil-DEX CB $25,0 \mathrm{~m} \times 0,25 \mathrm{~mm} \times 0,25 \mu \mathrm{m}$, temperatura inicial $120^{\circ} \mathrm{C}$ por 3 minutos, taxa de aquecimento: $4^{\circ} \mathrm{C} \cdot \mathrm{min}^{-1}$ por 11 minutos, temperatura final $165^{\circ} \mathrm{C}$, tempo total de análise 33 minutos, temperatura de detecção $270^{\circ} \mathrm{C}$.

$\mathrm{O}$ valor do excesso enantiomérico do produto $\left(e e_{p}\right)$ e do substrato $\left(e e_{s}\right)$ é considerado a medida de pureza enantiomérica e pode ser determinado experimentalmente por meio da Equação 17 e Equação 18, em que A e B são as concentrações relativas dos enantiômeros do substrato e C e D são as concentrações relativas dos produtos. Estes valores podem ser obtidos a partir das integrais das áreas dos respectivos pares enantioméricos após separação em colunas quirais.

$$
\text { ee } e_{\text {substrato }}=\frac{(A-B)}{(A+B)} \cdot 100
$$




$$
e e_{\text {produto }}=\frac{(C-D)}{(C+D)} \cdot 100
$$

A resolução cinética enzimática também pode ser utilizada para estimar a enantiosseletividade do processo por meio do cálculo da razão enantiomérica $(E)$ cujo valor é a razão entre as constantes de velocidade da reação de cada enantiômero (Equação 19 e Equação 20) a partir dos valores experimentais da conversão $c$ (Equação 21) (CHEN et al., 1982).

$$
\begin{gathered}
E=\frac{\ln \left[(1-c)\left(1-e e_{\text {substrato }}\right)\right]}{\ln \left[(1-c)\left(1+e e_{\text {substrato }}\right)\right]} \\
E=\frac{\ln \left[(1-c)\left(1-e e_{\text {produto }}\right)\right]}{\ln \left[(1-c)\left(1+e e_{\text {produto }}\right)\right]} \\
\% c=\frac{e e_{\text {substrato }}}{e e_{\text {substrato }}+e e_{\text {produto }}} \cdot 100
\end{gathered}
$$

Equação 21

O parâmetro E (razão enantiomérica) traduz em termos numéricos a seletividade enzimática, descrevendo a relação entre a conversão e os excessos enantioméricos do substrato $\left(e e_{s}\right)$ e do produto $\left(e e_{p}\right)$. Um valor elevado de E é essencial para o sucesso de uma resolução cinética, já que isto assegura não apenas um excesso enantiomérico elevado, mas também um rendimento proporcionalmente alto. Para propósitos práticos, um valor de E abaixo de 10 para qualquer biotransformação torna-a inviável como um processo enantiosseletivo. Por outro lado, este pode ser considerado bom se estiver situado entre aproximadamente 10 e 30 e, acima disto, excelente (CHEN et al., 1982; COSTA; AMORIM, 1999). 


\section{RESULTADOS E DISCUSSÃO}

\subsection{Caracterização da Celulose}

A mercerização pode provocar mudanças na estrutura morfológica da celulose podendo afetar suas propriedades tais como índice de cristalinidade, teor de $\alpha$-celulose, solubilidade e massa molar média (EL SEOUD et al., 2008; RAMOS et al., 2011a). Pretendeuse avaliar as alterações provocadas pela mercerização nas propriedades físico-químicas e térmicas assim como alterações na morfologia da celulose de linter, visando também correlacioná-las à dissolução da celulose no sistema de solvente empregado.

\subsubsection{Espectroscopia na Região do Infravermelho}

Os espectros na região do infravermelho (Figura 32) das amostras de celulose de linter, antes e após a mercerização, foram obtidos para fins comparativos.

Figura 32. Espectros na região do infravermelho para as amostras de celulose de linter e celulose de linter mercerizada.

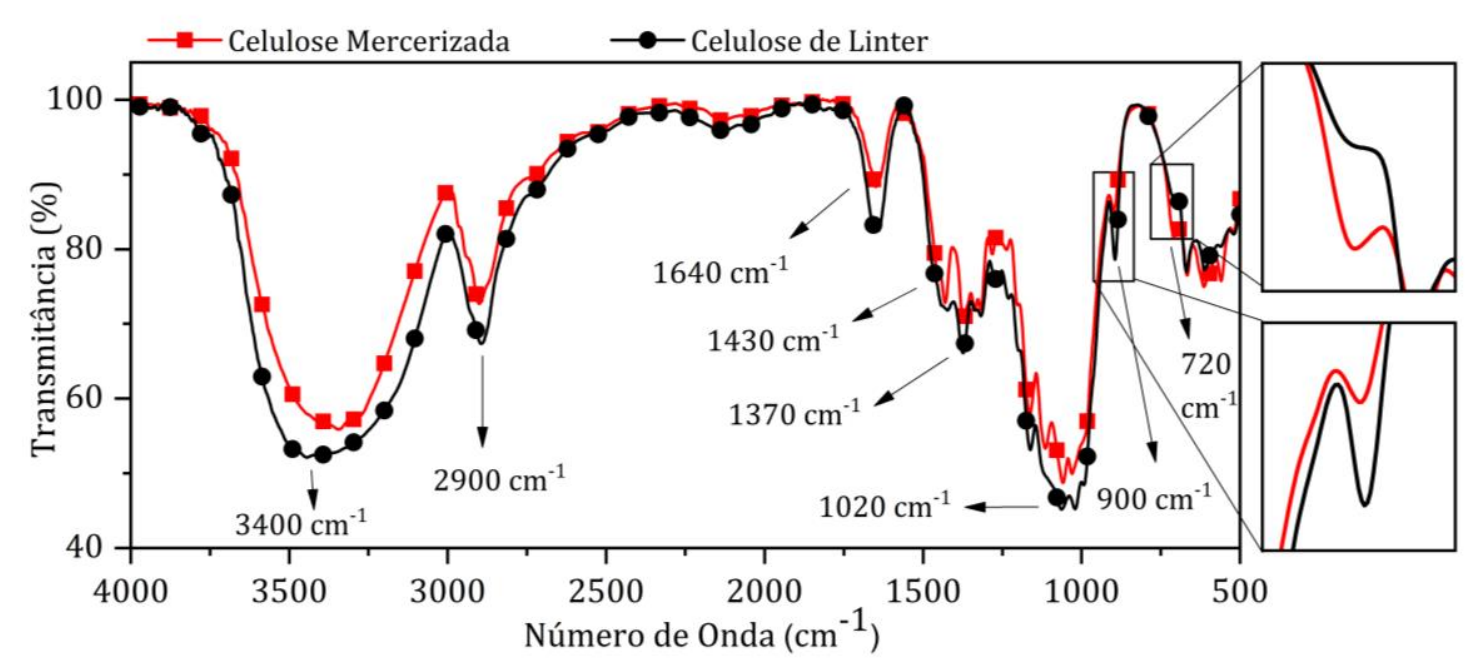

Bandas características de celulose podem ser observadas no espectro, tais como: estiramento da ligação $\mathrm{O}-\mathrm{H}$ em $3400 \mathrm{~cm}^{-1}$; estiramento da ligação $\mathrm{C}-\mathrm{H}$ em $2900 \mathrm{~cm}^{-1}$; deformação da ligação $\mathrm{O}-\mathrm{H}$ dos grupos hidroxílicos provenientes de água adsorvida em 1640 $\mathrm{cm}^{-1}$; vibrações de deformação no plano das ligações $\mathrm{H}-\mathrm{C}-\mathrm{H}$ e O-C-H em $1430 \mathrm{~cm}^{-1}$; vibração de deformação de ligações $\mathrm{C}-\mathrm{H}$ em $1370 \mathrm{~cm}^{-1}$; vibração de estiramento de ligações $\mathrm{C}-\mathrm{O}$ do esqueleto celulósico em $1020 \mathrm{~cm}^{-1}$; vibrações de deformação e estiramento de ligações C-O- 
C, C-C-O e C-C-H dos átomos de $\mathrm{C}_{(5)}$ e $_{(7)}$ em $900 \mathrm{~cm}^{-1}$; deformação fora do plano da ligação C-O-H em $670 \mathrm{~cm}^{-1}$ (ABIDI; CABRALES; HAIGLER, 2014).

As bandas de transmitância em $764 \mathrm{~cm}^{-1}$ e em $722 \mathrm{~cm}^{-1}$ são características de celulose I $\alpha$ e celulose I $\beta$ respectivamente (GORDON; HSIEH, 2007). Como observado no espectro, a celulose nativa não apresenta banda em $764 \mathrm{~cm}^{-1}$, indicando que a composição da celulose é do tipo I $\beta$. Verifica-se considerável diminuição da banda em $722 \mathrm{~cm}^{-1}$ comprovando a alteração cristalográfica de celulose I para celulose II.

O tratamento com solução alcalina não provocou alterações na estrutura química da celulose, comprovado pela similaridade dos espectros. No entanto, alterações na estrutura da celulose I (estrutura paralela) para celulose II (estrutura antiparalela) podem ser observadas através de uma alteração na intensidade na vibração da banda em $900 \mathrm{~cm}^{-1}$ (DINAND et al., 2002; OUAJAI; SHANKS, 2009).

\subsubsection{Teor de $\alpha$-celulose, Umidade, Cinzas e Análise Elementar}

O teor de $\alpha$-celulose, umidade, cinzas e porcentagens de nitrogênio $(\mathrm{N})$ e enxofre (S) foram determinados nas amostras de celulose de linter e celulose de linter mercerizada (Tabela 2).

Tabela 2. Teor de $\alpha$-celulose, umidade, cinzas e porcentagem de nitrogênio (N) e enxofre (S) para celulose de linter e celulose de linter mercerizada.

\begin{tabular}{cccccc}
\hline Amostra & $\begin{array}{c}\boldsymbol{\alpha} \text {-celulose } \\
(\boldsymbol{\%})\end{array}$ & $\begin{array}{c}\text { Umidade } \\
(\boldsymbol{\%})\end{array}$ & $\begin{array}{c}\text { Cinzas } \\
(\boldsymbol{\%})\end{array}$ & $\mathbf{N}(\boldsymbol{\%})$ & $\mathbf{S}(\boldsymbol{\%})$ \\
\hline Celulose de Linter & $90 \pm 1$ & $6,05 \pm 0,07$ & $0,076 \pm 0,007$ & N.D.* & N.D. \\
$\begin{array}{c}\text { Celulose de Linter } \\
\text { Mercerizada }\end{array}$ & $92,9 \pm 0,9$ & $7,6 \pm 0,1$ & $0,048 \pm 0,007$ & N.D. & N.D. \\
\hline *Não Detectado & & & &
\end{tabular}

O teor de $\alpha$-celulose representa a celulose pura, não contaminada pela presença de sais minerais, dentre outros contaminantes. Observou-se que o tratamento alcalino levou a um aumento no teor de $\alpha$-celulose (3\%), resultado condizente com estudos anteriores (RAMOS et al., 2005; MORGADO, 2009). Os dados indicaram um aumento no teor de pureza do material pela eliminação de ceras e pectinas. Este fato indica a importância da mercerização previamente às reações de esterificação da celulose, pois a presença de contaminantes durante a derivatização pode fazer com que ocorra uma diminuição efetiva de interação celulose/reagente 
interferindo, dessa forma, no grau médio de substituição do produto final (CIACCO et al., 2010). O teor de $\alpha$-celulose da celulose de linter mercerizada pode ser superior a aproximadamente 93\% (Tabela 2), tendo em vista que na massa pesada e utilizada no teste continha certa porcentagem de umidade, pois devido à alta higroscopicidade da celulose é difícil mantê-la livre de umidade.

A celulose de linter mercerizada apresenta um percentual de umidade maior que a celulose de linter. A diminuição da cristalinidade ocorrida como consequência do tratamento alcalino, conforme discutido posteriormente, facilitou a penetração da água, pois nas regiões não cristalinas as cadeias estão mais afastadas.

A determinação do teor de cinzas é uma maneira indireta de quantificar o teor de inorgânicos em biomateriais (SIXTA, 2006). Substâncias inorgânicas existem como resíduos metabólicos na forma de sais orgânicos simples ou ânions inorgânicos. Eles são essenciais para o crescimento do algodoeiro como nutrientes normais (FANG, 2018). Os principais elementos que compõem a fração inorgânica de biomassas celulósicas são cálcio, sílica, potássio e cloro (BAXTER et al., 1998). Verificou-se que o teor de cinzas obtido para a celulose de partida foi mínimo $(<0,1 \%)$, e após o tratamento alcalino a quantidade de cinzas foi ainda menor, indicando que na separação do linter do restante da biomassa a fração inorgânica foi praticamente eliminada.

A análise elementar determina a proporção dos elementos constituintes de uma amostra e foi realizada para as amostras de celulose de linter e celulose mercerizada e não houve detecção do elemento nitrogênio $(\mathrm{N} \%=0)$ ou enxofre $(\mathrm{S} \%=0)$ indicando que não há presença de impurezas e/ou contaminantes contendo estes elementos nas amostras de celulose. A presença de contaminantes de nitrogênio e enxofre poderia ser atribuída a utilização de compostos a base de nitrogênio e enxofre para correção de acidez e fertilidade do solo (FERREIRA; CARVALHO, 2005). A presença de enxofre também pode ser atribuída a pesticidas utilizados no controle de pragas e insetos (CZEPAK et al., 2005) no cultivo de algodão.

\subsubsection{Grau de Polimerização Médio Viscosimétrico}

Por meio das medidas de viscosidade, obteve-se o grau de polimerização médio viscosimétrico $\left(\mathrm{GP}_{\mathrm{visc}}\right)$ das amostras de celulose de linter não mercerizada e mercerizada. $\mathrm{A}$ partir dessas medidas calculou-se a massa molar média viscosimétrica $\left(\mathrm{MM}_{\mathrm{visc}}\right)$. A Tabela 3 expõe os valores obtidos para o grau de polimerização médio viscosimétrico e massa molar média viscosimétrica das amostras. 
Tabela 3. Grau de polimerização médio viscosimétrico e massa molar média viscosimétrica da celulose de linter e celulose mercerizada.

\begin{tabular}{ccc}
\hline Amostra & $\mathbf{M M}_{\text {visc }}\left(\mathbf{g} \cdot \mathbf{m o l}^{-1}\right)$ & $\mathbf{G P}_{\text {visc }}$ \\
\hline Celulose de Linter & $171164 \pm 1681$ & $1056 \pm 10$ \\
Celulose de Linter Mercerizada & $133256 \pm 905$ & $822 \pm 6$ \\
\hline
\end{tabular}

Os resultados indicam uma diminuição da massa molar média da celulose devido à mercerização. Isto está relacionado ao tratamento alcalino que pode levar a degradação parcial das cadeias de celulose, via hidrólise em meio alcalino.

A redução da massa molar média não foi muito acentuada, pois a mercerização foi realizada a temperatura de $0^{\circ} \mathrm{C}$ visando minimizar o efeito da degradação das cadeias de celulose.

\subsection{4 Índice de Cristalinidade}

Os difratogramas das amostras de celulose de linter antes e após a mercerização foram obtidos e, a partir deles, calculou-se os índices de cristalinidade. No processo de mercerização, o hidróxido de sódio penetra os domínios cristalinos da celulose ocasionando a conversão da estrutura da cadeia de celulose paralela (celulose I) para uma antiparalela (celulose II). Os difratogramas de raios $\mathrm{X}$ para o linter não tratado e linter mercerizado (Figura 33) mostram os picos característicos das estruturas cristalinas da celulose I e da celulose II.

Figura 33. Difratogramas de raios $\mathrm{X}$ das amostras de celulose de linter e celulose de linter mercerizada.
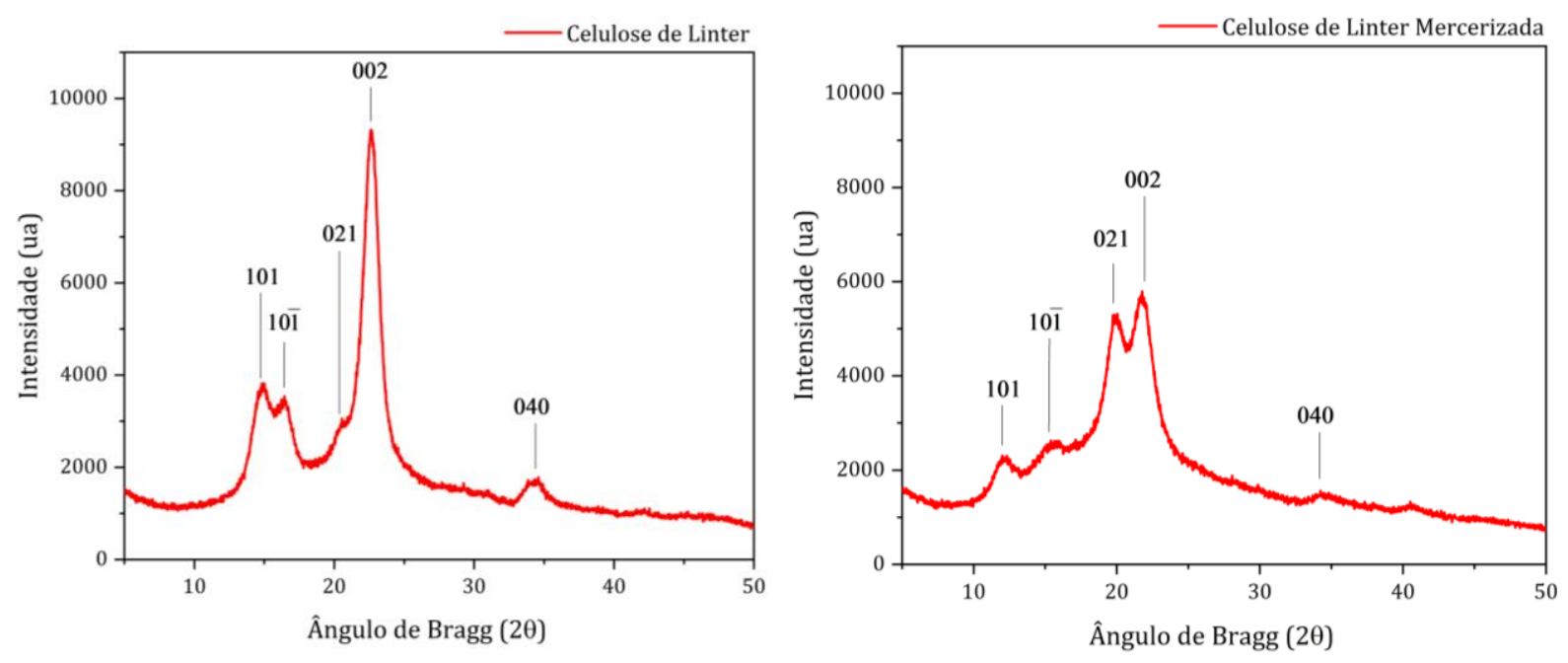
A mercerização provocou uma modificação da estrutura polimórfica da celulose I para celulose II. O difratograma da celulose de linter apresentou difrações características da forma polimórfica atribuída a celulose I, com difrações $2 \theta: 34^{\circ}$ (plano 040), $23^{\circ}$ (plano 002), $21^{\circ}$ (plano

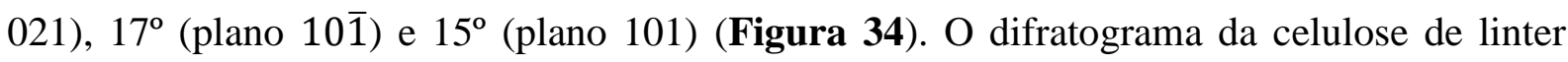
mercerizada apresentou difrações em 20: $20^{\circ}$ (plano 10 $\overline{1}$ ), $22^{\circ}$ (plano 002) e $13^{\circ}$ (plano 101) que representam planos típicos da celulose II (ASS; BELGAGEM; FROLLINI, 2006; QIN et al., 2008; YUE et al., 2012; GUPTA; UNIYAL; NAITHANI, 2013).

Figura 34. (a) Modelo bidimensional da estrutura cristalina da celulose com respectivos planos cristalinos; (b) modelo tridimensional da estrutura cristalina da celulose com respectivos planos cristalinos.

(a)

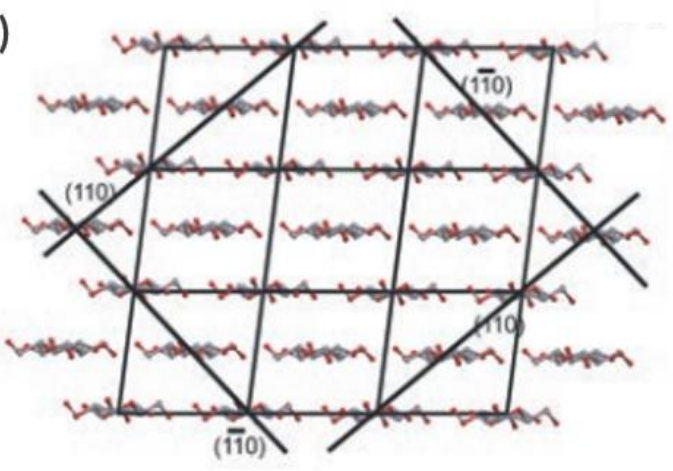

(b)

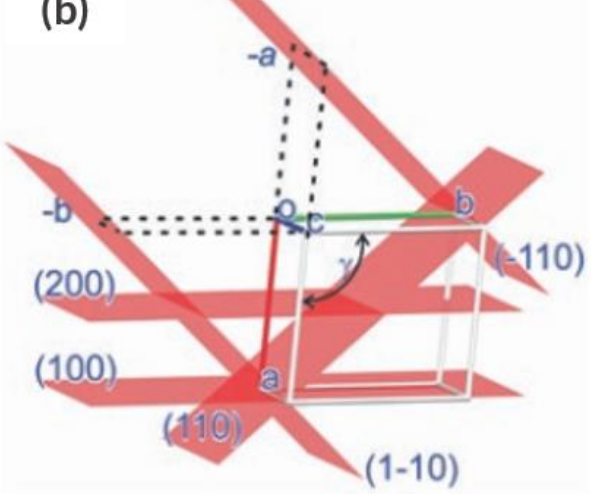

Fonte: adaptado FANG, 2018.

Dois métodos distintos foram utilizados para calcular o índice de cristalinidade da celulose. Em um método, índice de cristalinidade da celulose foi realizada por meio da diferença de picos $\left(\mathrm{I}_{\mathrm{C}}\right)$ (BUSCHLE-DILLER; ZERONIAN, 1992). Utilizou-se a intensidade máxima de difração $\left(2 \theta \cong 22-23^{\circ}\right.$ para celulose I e $2 \theta \cong 18-22^{\circ}$ para celulose II), correspondente às regiões cristalinas da amostra e a intensidade mínima de difração $\left(2 \theta \cong 18^{\circ}\right.$ para celulose $\mathrm{I}, 2 \theta \cong 16^{\circ}$ para celulose II), atribuída às regiões não cristalinas da amostra (FRENCH; SANTIAGO CINTRÓN, 2013; KASCHUK et al., 2017).

No outro método, o índice de cristalinidade da celulose foi determinado por meio da diferença de área através da integração dos picos cristalinos e banda não cristalina (RULAND, 1961; VONK, 1972).

Na Tabela 4 estão descritos os valores de índice de cristalinidade da celulose de linter e celulose de linter mercerizada calculados pelos dois métodos: por meio da diferença de picos (BUSCHLE-DILLER; ZERONIAN, 1992) e por meio da diferença de área (RULAND, 1961; VONK, 1972). 
Tabela 4. Índice de cristalinidade $\left(\mathrm{I}_{\mathrm{C}}\right)$ para celulose de linter e celulose de linter mercerizada.

\begin{tabular}{ccc} 
Amostra & $\mathbf{I}_{\mathbf{C}}$ diferença de picos $(\%)$ & $\mathbf{I}_{\mathbf{C}}$ diferença de áreas $(\%)$ \\
\hline Celulose de Linter & 62 & 53 \\
Celulose de Linter Mercerizada & 52 & 46 \\
\hline
\end{tabular}

Observou-se uma diminuição do índice de cristalinidade da celulose de linter após o tratamento alcalino para ambos os métodos empregados. Para a cristalinidade calculada por meio da diferença de picos $\left(\mathrm{I}_{\mathrm{C}}\right)$, observou-se redução de $62 \%$ para $52 \%$ com o processo de mercerização e de $53 \%$ para $46 \%$ do IC determinado pela diferença de áreas. A diferença causada na cristalinidade da celulose como consequência de mercerização depende da natureza do material de partida, da concentração da solução de $\mathrm{NaOH}$ usada, do tempo e da temperatura do tratamento, assim como da razão massa de celulose/volume de solução alcalina. Neste contexto, torna-se difícil comparar o resultado obtido neste estudo com outros reportados na literatura.

Comparando os resultados obtidos pelos dois métodos, o valor de $\mathrm{I}_{\mathrm{C}}$ para celulose de linter pelo método de Segal $\left(\mathrm{I}_{\mathrm{C}}=62 \%\right)$ foi mais elevado do que pelo médoto de Ruland-Vonk $\left(\mathrm{I}_{\mathrm{C}}=53 \%\right)$. O mesmo foi reportado por Ahvenainen et al., o índice de cristalinidade foi $76 \%$ para celulose de linter nativa utilizando o método de Segal, enquanto que utilizando o método de Ruland-Vonk, observou-se um valor de 55\% (AHVENAINEN; KONTRO; SVEDSTRÖM, 2016). No presente estudo, o conhecimento da cristalinidade também pelo médoto de RulandVonk foi importante, para efeitos de comparação com a cristalinidade dos ésteres sintetizados a partir da celulose mercerizada, em que foi usado este método.

De modo geral, pode-se concluir que o tratamento alcalino realizado levou a uma diminuição na proporção de regiões cristalinas presentes na celulose, evidenciado pela diminuição do índice de cristalinidade (KIM; LEE; KIM, 2016; SATARI; KARIMI; KUMAR, 2019). Verificou-se também a modificação da estrutura polimórfica da celulose I para celulose II, conforme verificado nos difratogramas.

A mudança conformacional é irreversível e acompanhada pela diminuição da cristalinidade da celulose. Na mercerização, ocorre uma penetração de $\mathrm{NaOH}$ entre as cadeias presentes nas regiões não cristalinas da celulose que são mais acessíveis, o que pode progredir para as regiões cristalinas, diminuindo a cristalinidade (BUSCHLE-DILLER; ZERONIAN, 1992; FIDALE, 2010; RAMOS et al., 2011a), aumentando o acesso de solventes e reagentes às cadeias de celulose. 
Por meio da difração de raios $\mathrm{X}$ foi possível determinar a dimensão média dos domínios cristalinos das amostras de celulose utilizando a equação de Scherrer (CULLITY; STOCK, 2014) (Tabela 5).

Tabela 5. Relação entre tamanho médio do cristalito e planos cristalográficos.

\begin{tabular}{ccc}
\hline \multirow{2}{*}{$\begin{array}{c}\text { Planos } \\
\text { cristalográficos }\end{array}$} & \multicolumn{2}{c}{ Tamanho médio do cristalito (nm) } \\
\cline { 2 - 3 }$(101)$ & Celulose de Linter & Celulose de Linter Mercerizada \\
\hline$(10 \overline{1})$ & 4,9 & 5,5 \\
$(021)$ & 7,3 & 2,6 \\
$(002)$ & 0,7 & 0,7 \\
$(040)$ & 5,9 & 2,1 \\
\hline Média & 3,2 & 0,1 \\
\hline
\end{tabular}

Observou-se tamanho médio do cristalito de 4,4 $\mathrm{nm}$ para celulose de linter, e após o tratamento alcalino houve uma redução do tamanho médio $(2,2 \mathrm{~nm})$. Leppänen et al. reportaram largura média dos cristalitos de linter de algodão não mercerizado de 7,1 nm (LEPPÄNEN et al., 2009), superior, portanto, ao valor médio encontrado neste estudo.

$O$ tratamento alcalino da celulose resultou na diminuição da porcentagem de cristalinidade (Tabela 4), e do tamanho médio dos cristalitos (Tabela 5), ou seja, alguns domínios cristalinos foram totalmente desestruturados (diminuindo a cristalinidade), e outros parcialmente (diminuindo o tamanho médio dos cristalitos. Estas modificações facilitam a acessibilidade do sistema de solvente ( $\mathrm{LiCl} / \mathrm{DMAc}$ ) às cadeias de celulose durante a etapa de dissolução.

\subsubsection{Microscopia Eletrônica de Varredura}

As características morfológicas e microestruturais da celulose de linter, mercerizada ou não, foram avaliadas por Microscopia Eletrônica de Varredura (MEV). A Figura 35 apresenta as micrografias obtidas. 
Figura 35. Micrografias de (a), (b), (c) celulose de linter; (d), (e), (f) celulose de linter mercerizada.
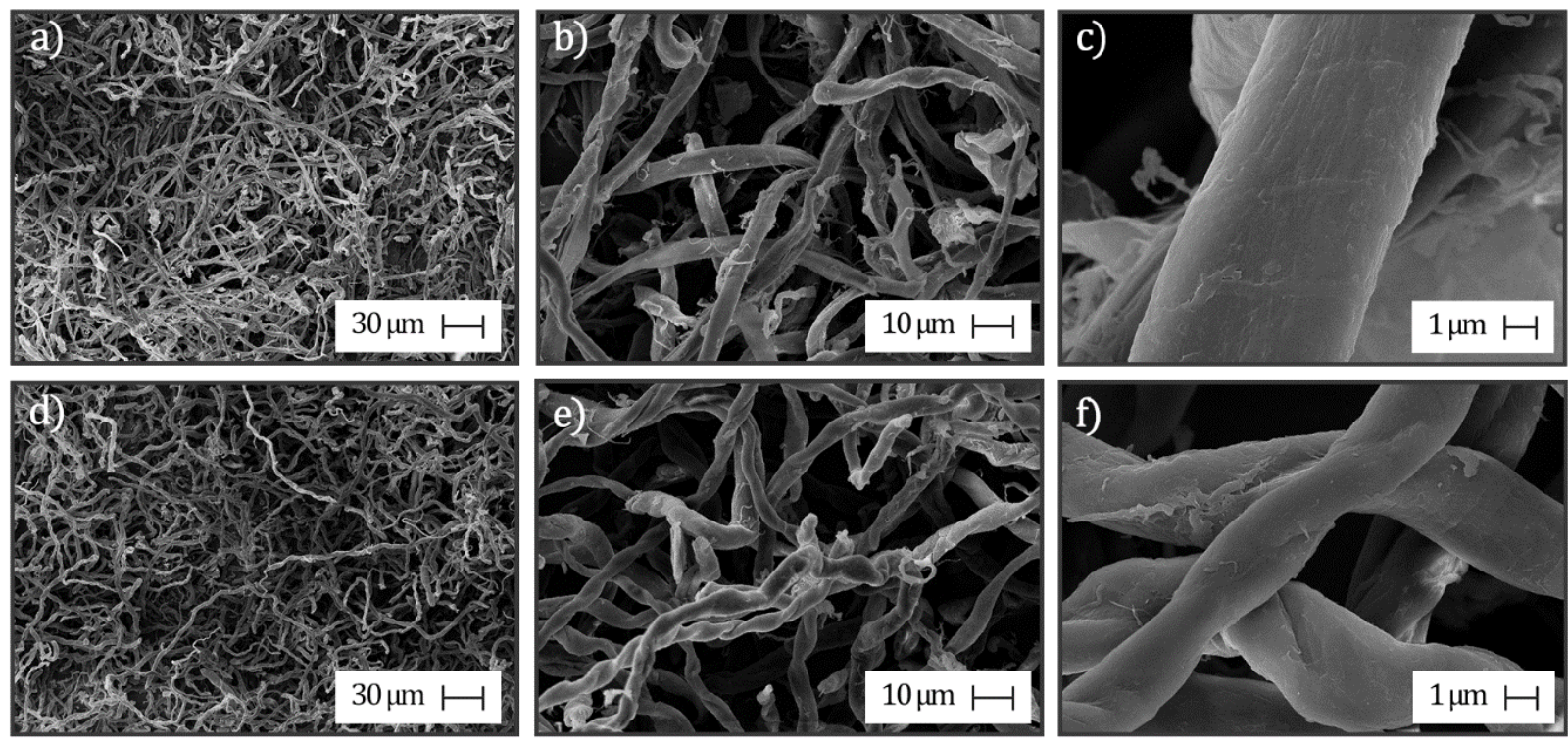

Observa-se que o processo de mercerização levou a fibras menos espessas e, comparando-se as micrografias da Figura 35c,f, observa-se que a mercerização levou ao surgimento de algumas fendas na superfície assim como a redução de fragmentos menores aderidos nas fibras. Como consequência da redução da espessura das fibras, há um aumento na área superficial da celulose de linter mercerizada comparativamente a celulose nativa (FIDALE, 2010) o que, aliado ao surgimento de fendas, torna mais fácil a penetração do solvente na fibra de celulose.

Segundo estudo anteriores, a mercerização da celulose também proporciona um aumento no volume dos microporos, geralmente localizados entre as fibrilas, microfibrilas e lamelas de celulose (EL SEOUD et al., 2008; CIACCO et al., 2010) e ainda aumenta a homogeneidade do tamanho dos poros na fibra (RAMOS, 2005). Estes fatores podem facilitar o acesso do solvente à celulose e levar, portanto, a uma solubilização mais eficiente comparado àquela com a celulose não tratada.

Comprovou-se então que o tratamento com solução alcalina provoca alteração da estrutura morfológica das fibras bem como conversão da estrutura cristalina da celulose, levando a uma alteração de celulose I para celulose II (EL SEOUD et al., 2008; CIACCO et al., 2010; RAMOS et al., 2011a). 


\subsubsection{Avaliação do Comprimento e Espessura Médios das Fibras}

A avaliação do efeito da mercerização no comprimento e espessura médios das fibras foi avaliada em analisador de fibras (MorFi Compact - Techpap), que detecta fibras de dimensões na escala micrométrica. A análise é realizada em ambiente restrito apenas às fibras, o que permite uma medição estatística confiável de milhares de fibras em alta velocidade e com determinação precisa das características relevantes de sua forma. Assim, as amostras foram suspensas em água e analisadas em equipamento MorFi pela medida de aproximadamente 5000 fibras. Não é possível uma comparação direta com resultados de MEV, obtidos com as fibras secas, pois os comprimentos e espessuras foram avaliados em meio aquoso, podendo ocorrer intumescimento das fibras, o que leva a alterações nas espessuras das mesmas. Assim, é somente possível comparar resultados de comprimento/espessura entre si, no caso de fibras mercerizadas e não mercerizadas.

$\mathrm{Na}$ Figura 36 constam os mapas tridimensionais da densidade que representam a distribuição das fibras, assim como gráfico de barras, de acordo com o comprimento e espessura para a celulose de linter e a celulose de linter mercerizada.

Comparando os mapas de densidade da celulose de linter e celulose mercerizada (Figura 36), e as respectivas figuras construídas com barras, observa-se que a mercerização levou à diminuição da ocorrência de fibras com maior comprimento ([599-1000] $\mu$ m e [359599] $\mu \mathrm{m}$ ), e ao aumento da ocorrência de fibras com menor comprimento ([215-359] $\mu \mathrm{m}$ e [129215] $\mu \mathrm{m}$ ), indicando que o álcali presente na solução aquosa atuou na parte intermediária das fibras mais longas, fragmentando-as em fibras menores. Os intervalos [77-129] $\mu \mathrm{m} \mathrm{e} \mathrm{[46-77] \mu m}$ permaneceram praticamente inalterados.

Com relação à espessura, observa-se que aumentou a ocorrência de fibras mais espessas $([50>] \mu \mathrm{m},[39-50] \mu \mathrm{m}, 30-39] \mu \mathrm{m})$, o que pode ser consequência da ação do álcali a partir da superfície de fibras muito espessas, com dimensões acima do limite de detecção do equipamento, e que após ação do álcali passaram a ser detectadas. Ainda, o fato de as fibras mercerizadas terem maior afastamento dos feixes de fibras e menor cristalinidade, pode favorecer o intumescimento de fibras pela penetração da solução, o que levaria a maior espessura. Para as fibras contidas no intervalo [18-23] $\mu \mathrm{m}$, ou de menor espessura, no geral se observou uma diminuição na ocorrência, indicando ação do álcali a partir da superfície durante a mercerização, hidrolisando cadeias de celulose e diminuindo a espessura. 
Figura 36. Mapa de densidade de comprimento e espessura das amostras de celulose de linter e a celulose de linter mercerizada e gráfico da distribuição de comprimento e espessura das amostras de celulose de linter e celulose mercerizada.
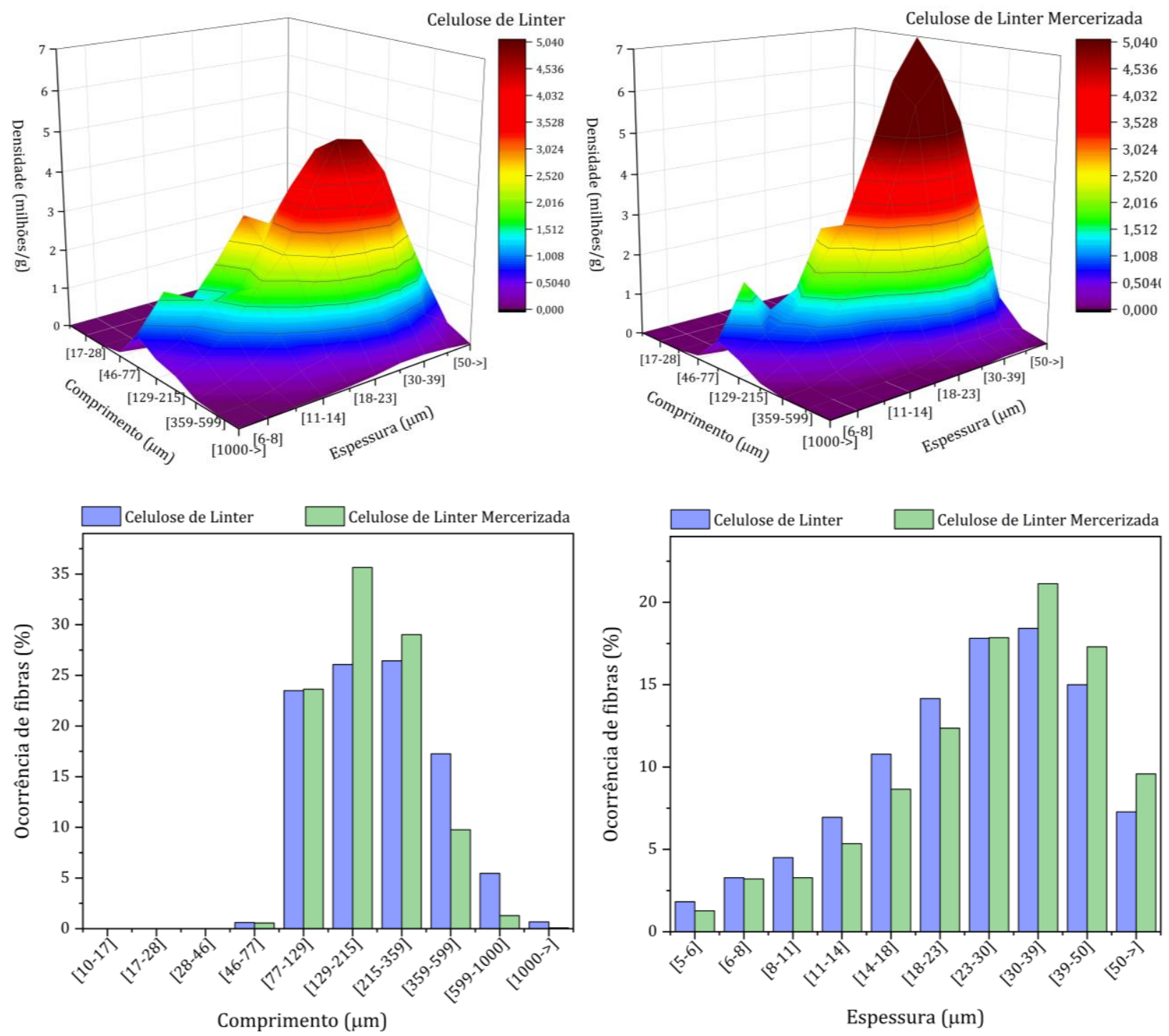

O processo de mercerização resultou na diminuição dos comprimentos e espessuras das fibras, o que consequentemente facilita a acessibilidade do solvente para posterior dissolução em sistema LiCl/DMAc.

\subsubsection{Análise Termogravimétrica}

A compreensão da decomposição térmica da celulose é fundamental para a conversão termoquímica da biomassa (SHEN; GU, 2009; CHEN et al., 2014). A análise termogravimétrica foi realizada a fim de verificar a estabilidade térmica da celulose antes e após o tratamento 
alcalino. As curvas TG para a celulose de linter de partida e celulose de linter mercerizada no intervalo de 20 a $800^{\circ} \mathrm{C}$, com suas respectivas derivadas (dTG) são mostradas na Figura 37.

A celulose pode ser classificada como um polímero de estabilidade térmica moderada. A complexidade da decomposição térmica da celulose resulta do grande número de etapas paralelas e consecutivas da reação, da mudança da rota de reação predominante com a temperatura de decomposição, da forte influência da atmosfera ambiente no processo.

Figura 37. Curvas TG/dTG da celulose de linter e da celulose de linter mercerizada (fluxo de $\mathrm{N}_{2}$ de $20 \mathrm{~mL} \cdot \mathrm{min}^{-1}$, razão de aquecimento de $20^{\circ} \mathrm{C} \cdot \mathrm{min}^{-1}$ ).
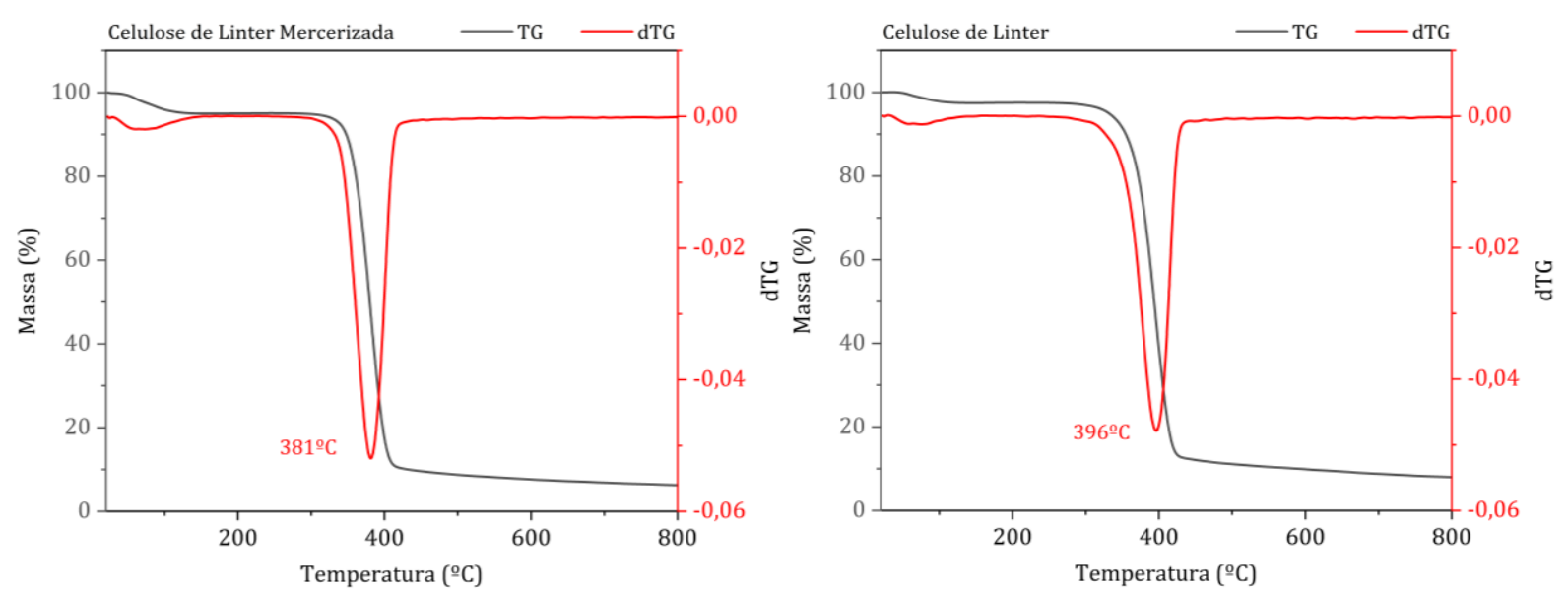

A degradação térmica da celulose consiste em três etapas principais (Figura 38) (MAMLEEV; BOURBIGOT; YVON, 2007; ZHANG et al., 2011; SANTMARTÍ; LEE, 2018). A primeira etapa é a ativação da celulose. Este processo inicial está ligado à cisão de ligações glicosídicas, levando a uma redução do grau de polimerização da celulose sem perder massa.

$\mathrm{O}$ segundo estágio com diminuição acentuada de massa, no intervalo entre $362-417^{\circ} \mathrm{C}$ para celulose de linter e $354-401^{\circ} \mathrm{C}$ para a celulose mercerizada, corresponde ao processo de decomposição da celulose por meio de uma série de reações químicas.

Figura 38. Mecanismo Broido-Shafizadeh de pirólise da celulose.

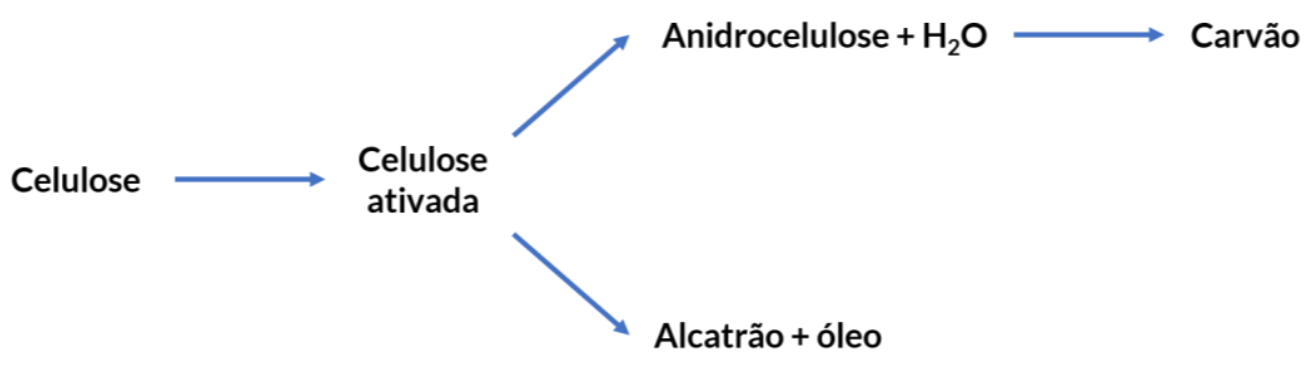

Fonte: adaptado MAMLEEV; BOURBIGOT; YVON, 2007. 
A primeira reação de decomposição da celulose leva à desidratação e formação de anidroglicose (Figura 39), a qual contém o grupo hidroxila e, no processo de decomposição, ocorre a formação da levoglucosana, produzida pela transglicosilação via reações intramoleculares (ZHANG et al., 2011).

Figura 39. Reação de eliminação de água na celulose durante decomposição térmica.
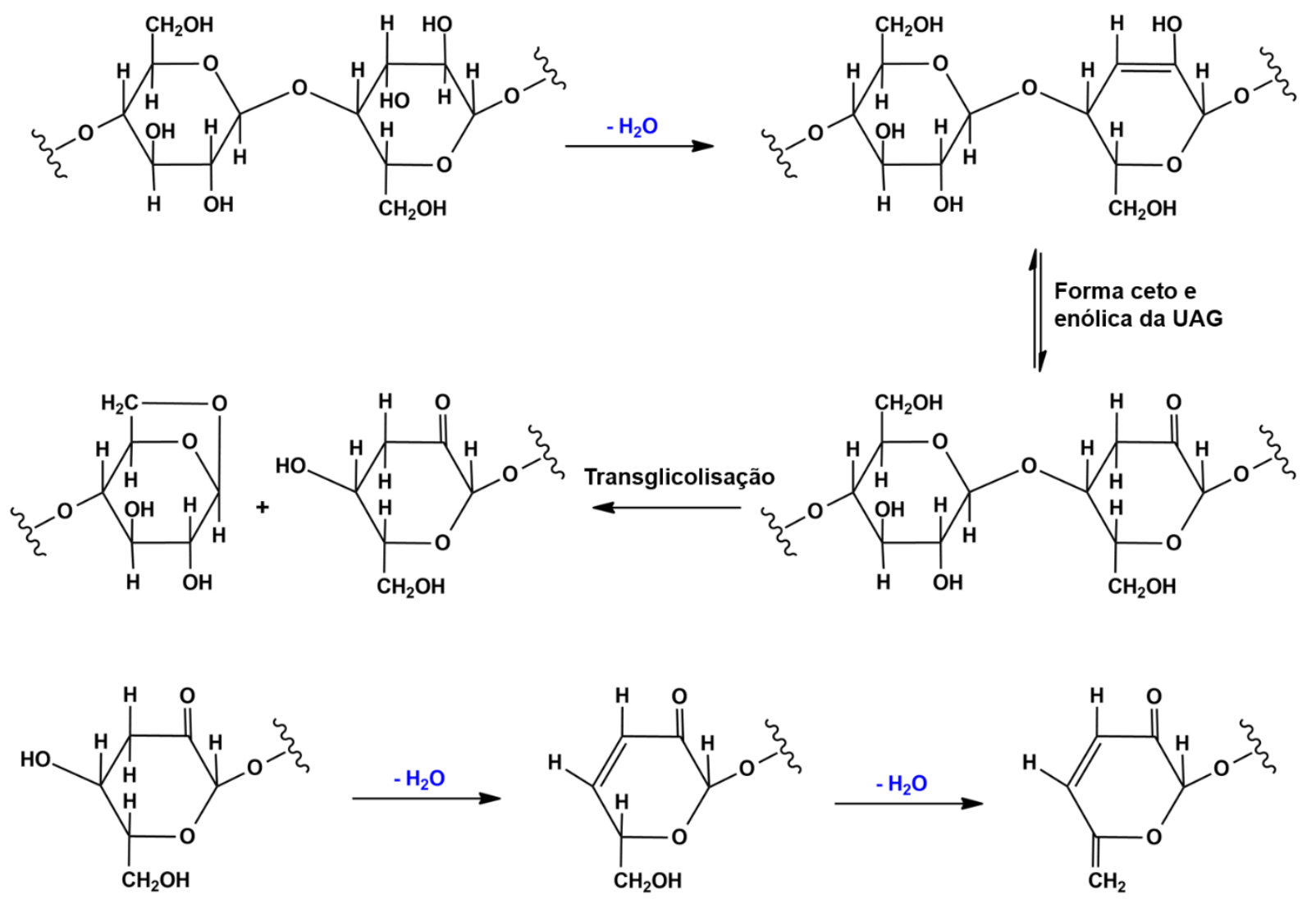

Fonte: adaptado SCHEIRS; CAMINO; TUMIATTI, 2001.

Após a ativação da celulose, duas reações de propagação competem entre si durante o processo de pirólise. Por um lado, a celulose ativa pode desidratar para dar lugar à anidrocelulose, que contribuirá para a formação de carvão sólido e gases de baixo peso molecular, como $\mathrm{CO}_{2}, \mathrm{CO}$ e $\mathrm{H}_{2} \mathrm{O}$. O primeiro estágio aparente na curva de $\mathrm{TG}$, no intervalo entre $25-110^{\circ} \mathrm{C}$, é associado à perda de umidade adsorvida (ou absorvida) pela celulose e corresponde ao processo de desidratação física (FLAQUÉ; MONTSERRAT, 1999).

Por outro lado, a celulose ativa pode se decompor em alcatrão, que consiste de em mistura de levoglucosana e outros bio-óleos, como hidroxiacetaldeído, hidroxiacetona e furfural (SHEN; GU, 2009). Estes produtos são obtidos pela despolimerização das cadeias de celulose e são mais inflamáveis que o carvão sólido. Embora ambas as reações ocorram durante o processo de pirólise da celulose, a reação de desidratação catalítica é favorecida a baixas 
temperaturas (abaixo de $100^{\circ} \mathrm{C}$ a $140^{\circ} \mathrm{C}$ ), enquanto a formação de bio-óleos é dominante em temperaturas mais altas (SANTMARTÍ; LEE, 2018).

A perda de massa no primeiro estágio está entre 3 e $5 \%$ para as celuloses analisadas (Tabela 6). A celulose mercerizada apresentou um maior percentual de perda de água (5\%) compara à celulose de linter (3\%). A massa de água absorvida é maior na celulose com menor índice de cristalinidade, ou seja, a celulose mercerizada. Isso ocorre devido à água penetrar mais facilmente nas regiões não cristalinas, devido maior distâncias entre as cadeias, comparativamente às regiões cristalinas (FENFEL; WEGENER, 1989; ASS; FROLLINI; HEINZE, 2004).

Tabela 6. Resultados de decomposição térmica da celulose de linter e celulose de linter mercerizada obtidos por análise termogravimétrica.

\begin{tabular}{|c|c|c|c|c|c|}
\hline Amostra & $\begin{array}{c}\text { Perda de massa } \\
1^{\circ} \text { estágio }(\%)\end{array}$ & $\underset{\text { decomposição }}{\mathbf{T}_{\text {inicial }}}\left({ }^{\circ} \mathrm{C}\right)$ & $\begin{array}{c}\mathbf{T}_{\text {pico dTG }} \\
\left({ }^{\circ} \mathbf{C}\right)\end{array}$ & $\begin{array}{c}\mathbf{T}_{\text {final }} \\
\text { decomposição } \\
\left({ }^{\circ} \mathrm{C}\right)\end{array}$ & $\begin{array}{c}\text { Perda de massa } \\
2^{\circ} \text { estágio }(\%)\end{array}$ \\
\hline Celulose de Linter & 3 & 362 & 396 & 417 & 85 \\
\hline $\begin{array}{l}\text { Celulose de Linter } \\
\text { Mercerizada }\end{array}$ & 5 & 354 & 381 & 401 & 86 \\
\hline
\end{tabular}

A celulose de linter começa a decomposição a uma temperatura mais elevada que a celulose mercerizada. A taxa de decomposição é mais rápida nas regiões não cristalinas, existentes entre as áreas cristalinas, sendo a que taxa de decomposição não é uniforme dentro das regiões não cristalinas (FLAQUÉ; MONTSERRAT, 1999). Como consequência, a temperatura que corresponde a taxa máxima de perda de massa $\left(\mathrm{T}_{\text {pico }}\right)$ é maior para a celulose de linter $\left(396^{\circ} \mathrm{C}\right)$ do que para a celulose mercerizada $\left(381^{\circ} \mathrm{C}\right)$. Nas regiões cristalinas, as ligações hidrogênio entre as cadeias são mais intensas que aquelas nas regiões não cristalinas, necessitando, portanto, maior energia durante o processo de decomposição (DUMITRIU, 2005; MORGADO et al., 2011). 


\subsection{Caracterização dos Ésteres Produzidos}

\subsubsection{Análise Elementar}

Após a precipitação dos ésteres em metanol, os mesmos foram submetidos a sucessivas lavagens a fim de remover totalmente $\mathrm{LiCl}$ e DMAc. A fim de detectar eventual presença do solvente DMAc, indicada pela presença de nitrogênio $(\mathrm{N})$, a análise elementar foi realizada (Tabela 7).

Tabela 7. Porcentagem dos elementos carbono $(\mathrm{C})$, hidrogênio $(\mathrm{H})$ e nitrogênio $(\mathrm{N})$ nas amostras de hexanoato e benzoato de celulose.

\begin{tabular}{|c|c|c|c|c|}
\hline Amostras & $\begin{array}{c}\text { Mol }_{\text {ag. esterificante }} \\
\text { MoloH da UAG }\end{array}$ & $\mathrm{C}(\%)$ & $\mathbf{H}(\%)$ & $\mathbf{N}(\%)$ \\
\hline \multirow{3}{*}{ Hex } & 3 & $54,3 \pm 1,2$ & $6,69 \pm 0,06$ & N.D.* \\
\hline & 6 & $58,1 \pm 1,9$ & $8,1 \pm 0,2$ & N.D. \\
\hline & 12 & $57,6 \pm 2,4$ & $6,9 \pm 0,3$ & N.D. \\
\hline \multirow{3}{*}{ Benz } & 3 & $53,2 \pm 0,4$ & $6,00 \pm 0,07$ & N.D. \\
\hline & 6 & $64,6 \pm 0,4$ & $5,11 \pm 0,03$ & $0,11 \pm 0,02$ \\
\hline & 12 & $63,9 \pm 0,9$ & $4,99 \pm 0,06$ & $0,08 \pm 0,02$ \\
\hline \multirow{2}{*}{ HexBenz } & 3 & $60,6 \pm 1,8$ & $8,3 \pm 0,2$ & $0,06 \pm 0,02$ \\
\hline & 6 & $53,6 \pm 0,4$ & $7,00 \pm 0,05$ & $0,11 \pm 0,09$ \\
\hline
\end{tabular}

*Não Detectado

Verificou-se que não foram encontradas quantidades residuais de nitrogênio para amostras de hexanoato de celulose e para amostra de Benz 3. Nas demais amostras foram encontrados traços de nitrogênio, porém as quantidades não foram significativas visto que quantidades em torno de $0,1 \%$ foram detectadas. Desse modo, comprovou-se que as lavagens dos ésteres de celulose foram eficientes para a eliminação de DMAc.

\subsubsection{Espectroscopia de Absorção Atômica (Lítio)}

A análise de absorção atômica de lítio foi realizada visando avaliar a eventual presença residual do solvente $\mathrm{LiCl}$ nos ésteres de celulose (Tabela 8). 
Tabela 8. Quantidade residual de lítio nas amostras de hexanoato e benzoato de celulose.

\begin{tabular}{ccc}
\hline Amostras & $\begin{array}{c}\text { Mol }{ }_{\text {ag. esterificantel }} \\
\text { MoloH da UAG }\end{array}$ & Li $\left(\boldsymbol{\mu g . L ^ { - 1 }}\right.$ ou ppb) \\
\hline Hex & 6 & N.D.* \\
& 12 & N.D. \\
Benz & 3 & N.D. \\
\hline HexBenz & 6 & $16,4 \pm 0,8$ \\
& 12 & $190,9 \pm 0,9$ \\
& 3 & $56,8 \pm 1,4$ \\
\hline
\end{tabular}

*Não Detectado

Após a síntese dos ésteres de celulose, os mesmos foram submetidos a sucessivas lavagens com água destilada a fim de eliminar traços residuais do sistema de solvente LiCl/DMAc. Conforme verificado na Tabela 8, não foram encontradas quantidades residuais de íons lítio nas amostras de hexanoato de celulose. Nas demais amostras, observou-se traços de íons lítio, porém as quantidades não foram significativas visto que que foram determinadas quantidades inferiores a $1 \mathrm{ppm}$.

\subsubsection{Espectroscopia na Região do Infravermelho}

O espectro na região do infravermelho (Figura 40) para as amostras de hexanoato de celulose e benzoato de celulose, assim como de ésteres mistos, foram obtidos e as bandas de absorção foram analisadas a fim de verificar se alterações provocadas pela derivatização da celulose.

A principal diferença entre as amostras celulose e dos demais ésteres é a diminuição da intensidade e mudança no perfil observado para a banda de $3400 \mathrm{~cm}^{-1}$ atribuída ao estiramento da ligação $\mathrm{O}-\mathrm{H}$ dos grupos hidroxila da celulose, devido à substituição parcial dos grupos durante a reação de esterificação. A esterificação da celulose promoveu uma diminuição na absorção do grupo hidroxila da celulose e o aparecimento de uma nova banda em torno de $1750 \mathrm{~cm}^{-1}$, atribuída a carbonila do grupo éster. 
Figura 40. Espectros de absorção na região do infravermelho para hexanoatos de celulose, benzoatos de celulose e hexanoato-benzoato de celulose.
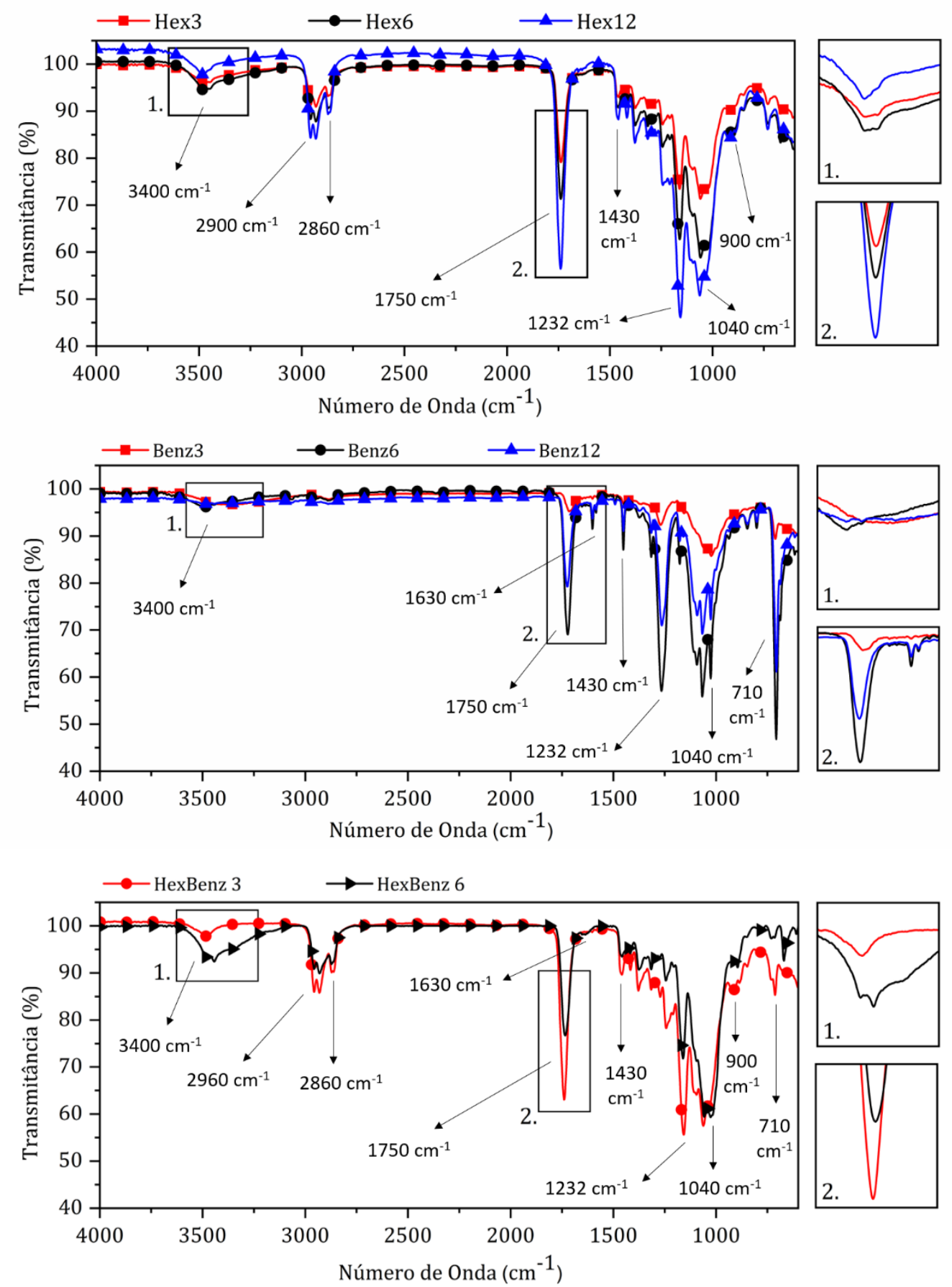

1.

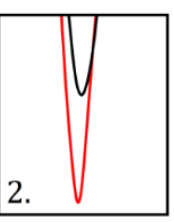

Os comprimentos de onda que indicaram a presença de bandas características e suas respectivas atribuições são descritos na Tabela 9. 
Tabela 9. Possível atribuição de bandas observadas nos espectros IV de hexanoato de celulose, benzoato de celulose e hexanoato-benzoato de celulose.

\begin{tabular}{lc}
\hline \multicolumn{1}{c}{ Atribuição } & Comprimento de Onda $\left.\mathbf{( c m}^{-1}\right)$ \\
\hline Estiramento -O-H & 3400 \\
Estiramento -C-H do anel aromático & 3060 \\
Estiramento -C-H da ligação $\mathrm{CH}_{2}$ & 2900 \\
Estiramento -C-H da ligação $\mathrm{CH}_{3}$ & 2860 \\
Deformação axial -C=O & 1750 \\
Estiramento C=C do anel aromático & 1630 \\
Estiramento C=C do anel aromático & 1590 \\
Deformação $\mathrm{CH}{ }_{2}$ & 1430 \\
Ligação C-CH $\mathrm{H}_{3}$ & 1380 \\
Deformação axial (C=O)-O & 1232 \\
Deformação axial simétrica da ligação C-O-C & 1040 \\
Dobramento C=C-H & 900 \\
\hline
\end{tabular}

Analisando os espectros de hexanoatos de celulose Figura 40, observou-se o surgimento de bandas características de grupos éster, ou seja, além da banda referente à deformação axial da carbonila em $1750 \mathrm{~cm}^{-1}$, há também bandas referentes à ligação $\mathrm{C}-\mathrm{CH}_{3}$ do grupo hexila em $1380 \mathrm{~cm}^{-1}$ e banda de deformação axial de $\mathrm{O}-(\mathrm{C}=\mathrm{O})$ a $1232 \mathrm{~cm}^{-1}$ do éster (ASS; FROLLINI; HEINZE, 2004; LEE; BLAKER; BISMARCK, 2009). No espectro observou-se a redução da intensidade banda de $3400 \mathrm{~cm}^{-1}$ atribuída ao estiramento da ligação $\mathrm{O}-\mathrm{H}$ conforme o aumento do grau médio de substituição. O mesmo pode ser verificado com a banda da carbonila, houve um aumento na intensidade da banda em $1750 \mathrm{~cm}^{-1}$, conforme o aumento do grau médio de substituição do éster.

Nos espectros de benzoato de celulose, as bandas na região de 1630 e $1590 \mathrm{~cm}^{-1}$ podem ser atribuídas às vibrações $\mathrm{C}=\mathrm{C}$ do anel aromático. Outros picos do anel benzênico podem ser identificados em $3060 \mathrm{~cm}^{-1}$ para estiramento $-\mathrm{C}-\mathrm{H}$ do anel aromático, $1430 \mathrm{~cm}^{-1}$ para estiramento $\mathrm{C}=\mathrm{C}$ aromático e $710 \mathrm{~cm}^{-1}$ para deformação $\mathrm{C}-\mathrm{H}$ fora do plano do benzeno (SAIRAM et al., 2003; ZHANG et al., 2009; KIM et al., 2018). O aumento da razão molar do reagente levou a uma intensificação da banda referente ao grupo carbonila, bem como a redução da banda referente ao grupo hidroxila.

Comparando os espectros de hexanoato e benzoato de celulose, houve uma redução mais significativa na intensidade das bandas em $3400 \mathrm{~cm}^{-1} \mathrm{em}$ benzoatos, indicando uma maior substituição das hidroxilas, conforme esperado devido a maior reatividade do cloreto de acila, comparativamente ao anidrido. 
Nos espectros de ésteres mistos, ambos os conjuntos de bandas para hexanoato e benzoato foram observados. Além da banda referente à carbonila em $1750 \mathrm{~cm}^{-1}$, observou-se banda referente à ligação $\mathrm{C}-\mathrm{CH}_{3}$ em $1380 \mathrm{~cm}^{-1}$ e banda de deformação axial de $\mathrm{O}-(\mathrm{C}=\mathrm{O})$ a $1232 \mathrm{~cm}^{-1}$ relacionadas ao grupo hexila, e também as bandas em $3060 \mathrm{~cm}^{-1}$ de estiramento -C$\mathrm{H}$ do anel aromático, $1430 \mathrm{~cm}^{-1}$ de estiramento $\mathrm{C}=\mathrm{C}$ aromático e $710 \mathrm{~cm}^{-1}$ de deformação $\mathrm{C}-\mathrm{H}$ relacionadas ao grupo fenila.

De modo geral, os espectros apresentaram o mesmo padrão, variando apenas a intensidade de algumas bandas conforme a variação da razão molar do reagente acilante na reação que levou aos ésteres. A banda em $3400 \mathrm{~cm}^{-1}$, atribuída ao estiramento da ligação O-H dos grupos hidroxila da celulose, diminui conforme ocorre a substituição por grupos éster durante a reação de esterificação. A banda na região de $1750 \mathrm{~cm}^{-1}$, proveniente da deformação $\mathrm{C}=\mathrm{O}$, aumenta conforme ocorre a inserção de grupos éster na celulose.

\subsubsection{Determinação do Grau Médio de Substituição}

\subsubsection{Espectroscopia de Ressonância Magnética Nuclear $\left({ }^{1} \mathrm{H}\right)$}

A espectroscopia de ressonância magnética nuclear permitiu calcular o grau médio de substituição (GS) dos ésteres de celulose. Na Figura 41 são apresentados os espectros de RMN${ }^{1} \mathrm{H}$ de hexanoatos de celulose, benzoatos de celulose e hexanoato-benzoato de celulose.

Observou-se em todos espectros de $\mathrm{RMN}-{ }^{1} \mathrm{H}$ os picos relativos à ressonância dos prótons da cadeia de glicose da celulose na faixa de 2,7 a 5,5 ppm. Nos espectros referentes aos hexanoatos de celulose, observou-se, além dos picos de ressonância dos prótons da celulose, os picos relativos à ressonância dos prótons do grupo hexila ligado às carbonila na faixa de 1,7 a 2,5 ppm. Nos espectros referentes aos benzoatos de celulose, os picos relativos à ressonância dos prótons do anel benzeno foram visíveis de 7,0 a 8,5 ppm. Para os hexanoato-benzoato de celulose ambos os conjuntos de picos foram verificados. O pico em 2,5 ppm está relacionado com o solvente DMSO- $\mathrm{d}_{6}$. Nos espectros de benzoato e hexanoato-benzoato de celulose foram observados picos do solvente residual (seção 3.6.2) em torno de 1,5-2,0 ppm (DAWSEY; MCMORMICK, 1990; KIM et al., 2018). 
Figura 41. Espectros de $\mathrm{RMN}-{ }^{1} \mathrm{H}$ em $\mathrm{DMSO}-\mathrm{d}_{6}$ para a amostra hexanoatos, benzoatos de celulose e ésteres mistos com diferentes graus médios de substituição.
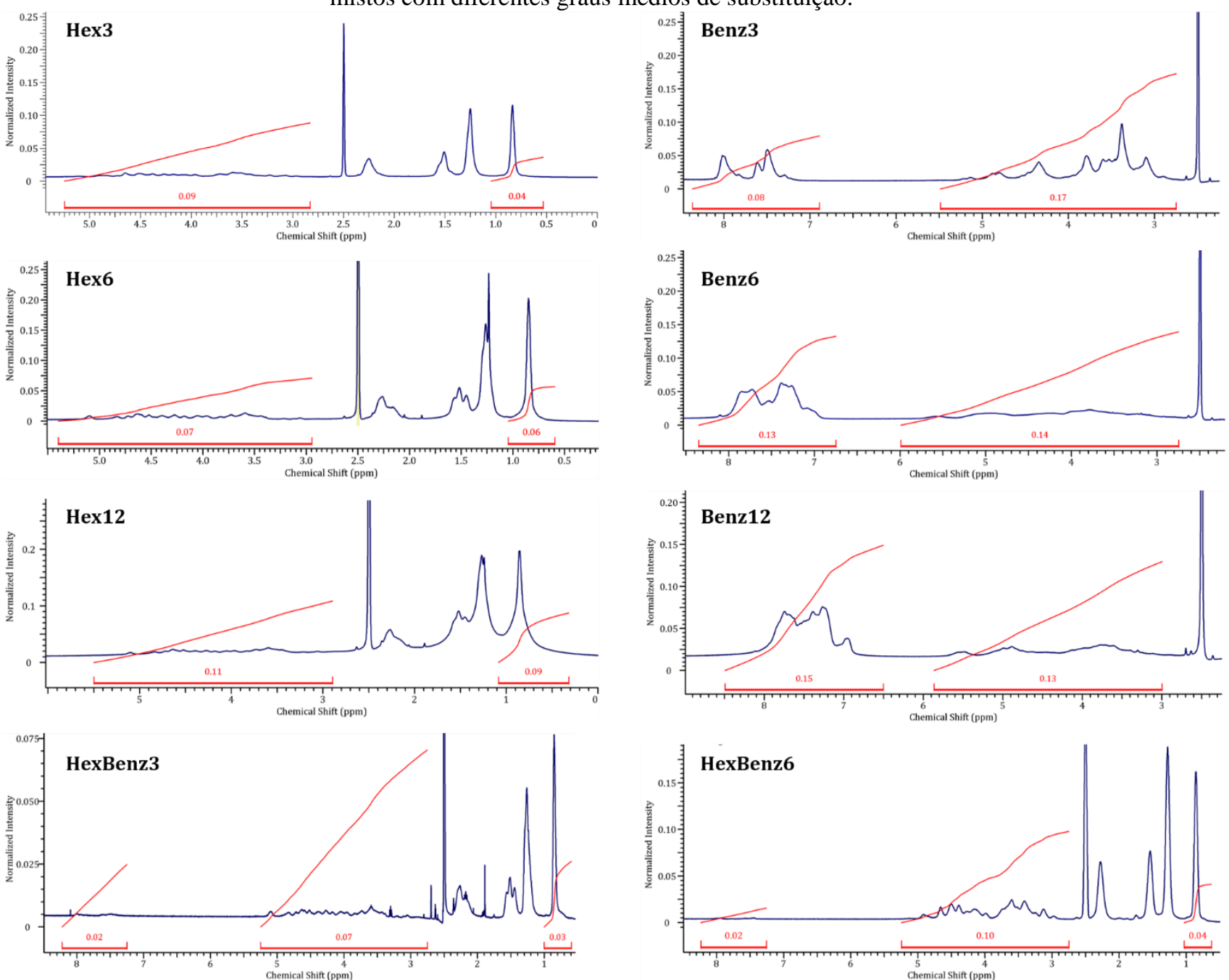

Relacionando a área de ressonância dos prótons do grupo alquila/fenila ligados às carbonilas e a área de ressonância dos prótons dos anéis de glicose descritos na seção 3.6.6.1 foi possível calcular os graus médios de substituição (GS) dos ésteres. Na Tabela 10 estão descritos os resultados de grau médio de substituição para os diferentes ésteres de celulose de linter obtidos no sistema de solvente LiCl/DMAc.

Como previamente abordado, excessos de agentes esterificantes foram utilizados $\left(\mathrm{Mol}_{\text {ag. esterificante }} / \mathrm{Mol}_{\mathrm{OH} \text { de UAG }}>3\right)$ visando obter ésteres com diferentes GS, visto a impossibilidade de obtenção de GS estequiométricos. Observa-se que o aumento da razão molar aumentou o GS do hexanoato de celulose conforme a expectativa.

Hexanoatos de celulose apresentaram valores de grau médio de substituição muito próximos aos valores esperados. 
Tabela 10. Grau médio de substituição dos ésteres de celulose.

\begin{tabular}{cccccc}
\hline Amostra & $\begin{array}{c}\text { Razão } \\
\text { molar }\end{array}$ & $\begin{array}{c}\text { Integral prótons do } \\
\text { grupo alquila ligados } \\
\text { às carbonilas }\end{array}$ & $\begin{array}{c}\text { Integral dos prótons } \\
\text { dos anéis de glicose }\end{array}$ & $\begin{array}{c}\text { GS } \\
\text { esperado }\end{array}$ & $\begin{array}{c}\text { GS } \\
\text { obtido }\end{array}$ \\
\hline \multirow{3}{*}{ Hex } & 3 & 0,04 & 0,09 & 1,0 & 1,0 \\
& 6 & 0,06 & 0,07 & 2,0 & 2,0 \\
\hline \multirow{3}{*}{ Benz } & 12 & 0,11 & 0,09 & 3,0 & 2,8 \\
\hline \multirow{2}{*}{ HexBenz } & 3 & 0,17 & 0,08 & 1,0 & 0,7 \\
& 6 & 0,13 & 0,14 & 2,0 & 1,3 \\
\multirow{2}{*}{ HexBenz } & 12 & 0,15 & 0,13 & 3,0 & 1,6 \\
\hline & $(1,5: 1,5)$ & 0,03 (benzoato) & 0,07 & 0,5 & 1,0 \\
& $6,0: 3,0)$ & 0,04 (hexanoato) & & 0,5 & 1,0 \\
\hline
\end{tabular}

Os benzoatos de celulose apresentaram valores de grau médio de substituição aquém da expectativa gerada pela razão molar considerada. Para Benz 3 o GS $=0,7$ foi próximo ao esperado (GS =1,0), e para Benz 6 e Benz 12 os GSs obtidos foram 1,3 e 1,6, enquanto os valores planejados pelo uso de excesso de agente esterificante foi 2,0 e 3,0, respectivamente As intensidades das bandas referentes aos grupo carbonila destes ésteres indicaram GSs diferentes dos calculados via $\mathrm{RMN}-{ }^{1} \mathrm{H}$, o que levou ao cálculo dos mesmos a partir de resultados de análise elementar.

Para o éster misto de celulose HexBenz 3, o valor obtido individualmente para cada grupo $\left(\mathrm{GS}_{\mathrm{Hex}} / \mathrm{GS}_{\mathrm{Benz}}=1,0 / 1,0\right)$ foi superior ao esperado para o GS total, ou seja, $\mathrm{GS}_{\mathrm{Hex}+\mathrm{Benz}}$ $=1,0$, enquanto para HexBenz 6 o GS $\mathrm{Hex}_{\mathrm{H}} / \mathrm{GS}_{\mathrm{Benz}}=0,9 / 0,3$ foi menor que o planejado $\left(\mathrm{GS}_{\mathrm{Hex}+\mathrm{Benz}}\right.$ $=2,0)$. Os resultados de grau médio de substituição menores que o esperado dos benzoato de celulose e éster misto divergem dos espectros na região de infravermelho obtidos (seção 4.2.3). Os espectros indicaram elevada substituição, devido à intensidade das bandas de carbonila. Os GS obtidos por meio da espectroscopia de $\mathrm{RMN}-{ }^{1} \mathrm{H}$ dependem da solubilização total dos ésteres de celulose em solvente deuterado, assim como os picos nos espectros devem estar livres de interferência (sem sobreposição de picos) seja da própria macromolécula, seja do solvente. Uma possível explicação seria a solubilização parcial destes ésteres, mascarando os resultados de grau médio de substituição. 


\subsection{5 Índice de Cristalinidade}

Os difratogramas de raios X para os ésteres de celulose foram obtidos. A Figura $\mathbf{4 2}$ compara os difratogramas obtidos para hexanoato, benzoatos e ésteres mistos de celulose com diferentes razões molares (Molag. esterificante/MoloH da UAG).

Figura 42. Difratogramas de raios $X$ das amostras de hexanoatos de celulose e benzoatos de celulose.
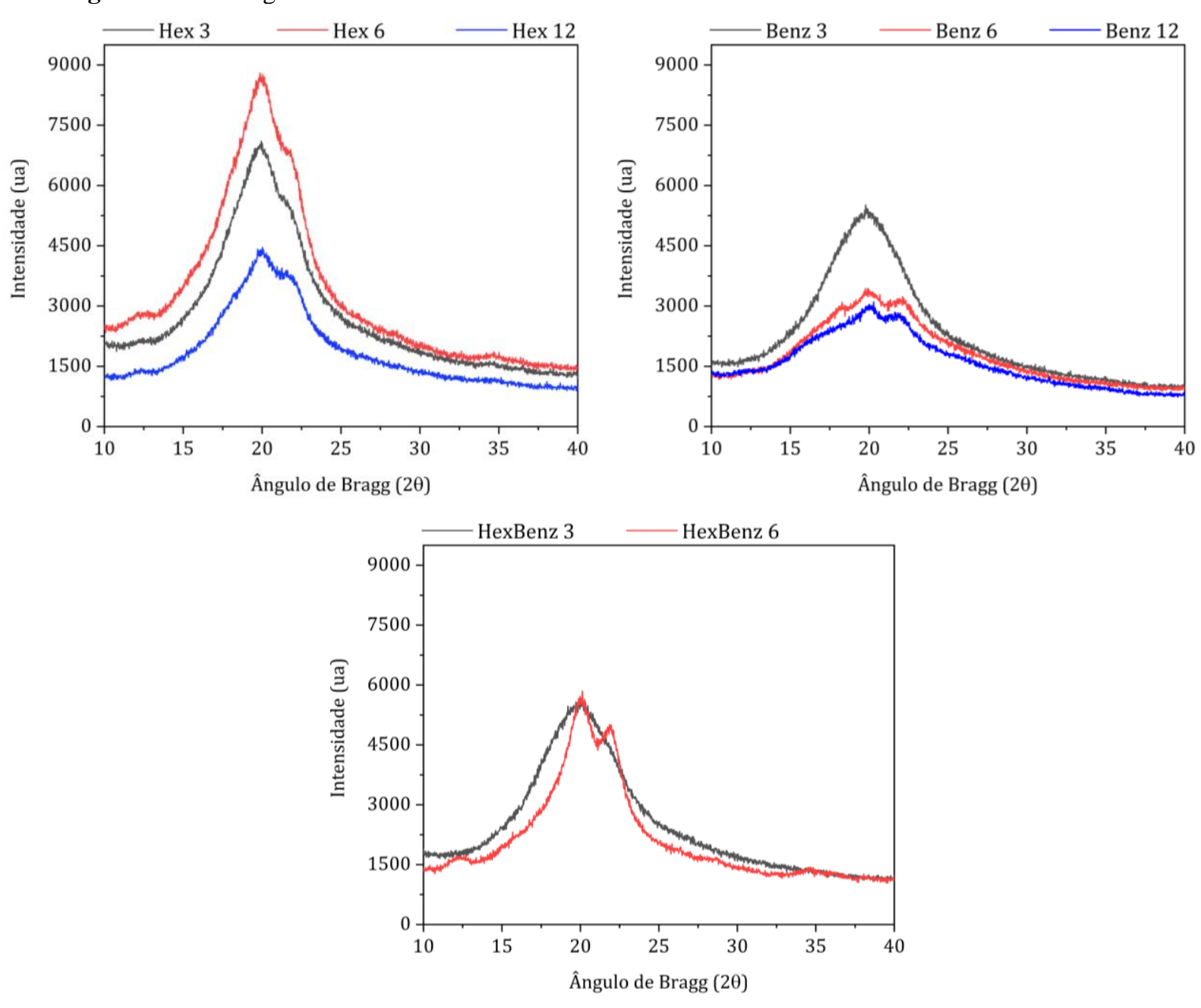

O índice de cristalinidade da celulose por meio da diferença de área (RULAND, 1961; VONK, 1972). A determinação do $I_{C}$ foi realizada por meio da integração dos picos cristalinos e banda não cristalina (RULAND, 1961; VONK, 1972). Os resultados obtidos estão descritos na Tabela 11.

Os ésteres com maior razão molar apresentaram índice de cristalinidade menor que ésteres com menor razão molar. Esta redução no valor da cristalinidade ocorreu devido a substituição das hidroxilas pelos grupos hexila, o que levou a um afastamento entre as cadeias pelo fato de os grupos apresentarem elevado volume. Isto torna as interações intermoleculares 
menos intensas, e como consequência, diminuem a organização dos segmentos das cadeias e as regiões cristalinas dos ésteres.

Tabela 11. Índice de cristalinidade ( $\mathrm{I}_{\mathrm{C}}$ ) para celulose de linter mercerizada e ésteres de celulose.

\begin{tabular}{cc}
\hline Amostra & $\mathbf{I}_{\mathbf{C}}$ diferença de áreas (\%) \\
\hline Celulose de Linter Mercerizada & 46 \\
\hline Hex 3 & 71 \\
Hex 6 & 74 \\
Hex 12 & 59 \\
\hline Benz 3 & 66 \\
Benz 6 & 49 \\
Benz 12 & 54 \\
\hline HexBenz 3 & 67 \\
HexBenz 6 & 60 \\
\hline
\end{tabular}

Comparativamente à celulose mercerizada, os resultados mostraram que a derivatização da celulose em solvente $\mathrm{LiCl} / \mathrm{DMAc}$ levou a um aumento na proporção de regiões cristalinas. Os hexanoatos de celulose apresentaram os índices de cristalinidade maior que pode ser atribuído à flexibilidade da cadeia hidrocarbônica com grupo hexanoato adicionado, o que permite que assuma conformações que facilitem a ordenação de cadeias, com interações intermoleculares hidrofóbicas atrativas entre os grupos hexanoatos apolares.

O mesmo foi observado para a derivatização utilizando cloreto de benzoíla, resultando no aumento do índice de cristalinidade. Os resultados indicam que interações hidrofóbicas podem ter levado ao aumento na cristalinidade.

\subsubsection{Análise Termogravimétrica}

Por meio da análise termogravimétrica, avaliou-se o comportamento térmico dos ésteres de celulose obtidos a partir de celulose de linter preparados em meio homogêneo LiCl/DMAc. A empregabilidade dos ésteres de celulose nas diversas aplicações é fortemente influenciada pelos processos de decomposição térmica (LUCENA et al., 2003; RAMOS et al., 2011b). As curvas TG para hexanoatos de celulose e benzoatos de celulose no intervalo de 20 a $800^{\circ} \mathrm{C}$, com suas respectivas derivadas (dTG) são mostradas na Figura 43. 
Figura 43. Curvas TG/dTG dos hexanoatos e benzoatos de celulose com diferentes razões molares (fluxo de $\mathrm{N}_{2}$ de $20 \mathrm{~mL} \cdot \mathrm{min}^{-1}$, razão de aquecimento de $20^{\circ} \mathrm{C} \cdot \mathrm{min}^{-1}$ ).
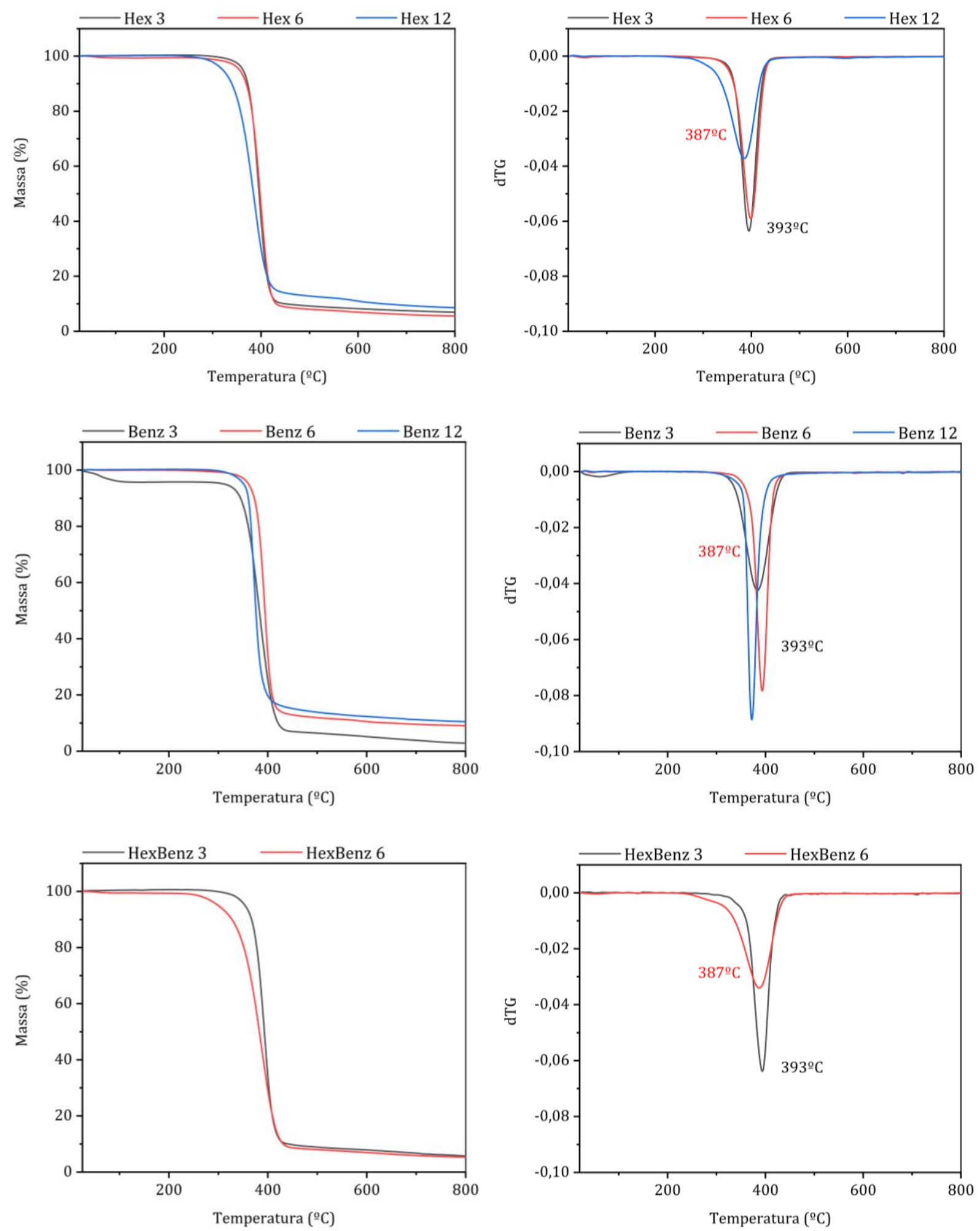

As curvas TG/dTG apresentaram o mesmo perfil daquela de linter de celulose mercerizado, ou seja, um primeiro estágio de perda entre 25 e $110^{\circ} \mathrm{C}$, associado à perda de umidade adsorvida (ou absorvida) e corresponde ao processo de desidratação física (FLAQUÉ; 
MONTSERRAT, 1999), e um segundo estágio com diminuição acentuada de massa, no intervalo entre $299-416^{\circ} \mathrm{C}$ corresponde à perda dos grupos alquila e fenila presentes na estrutura dos ésteres de celulose e a cisão da cadeia polimérica.

Na Tabela 12 são encontradas as descrições dos parâmetros obtidos a partir das curvas TG/dTG dos ésteres analisados.

Tabela 12. Resultados de decomposição térmica dos ésteres de celulose obtidos por análise termogravimétrica.

\begin{tabular}{|c|c|c|c|c|c|}
\hline Amostra & $\begin{array}{c}\text { Perda de massa } \\
1^{\circ} \text { estágio }(\%)\end{array}$ & $\begin{array}{c}\mathbf{T}_{\text {inicial decomposição }} \\
\left({ }^{\circ} \mathbf{C}\right)\end{array}$ & $\begin{array}{c}\mathbf{T}_{\text {pico dTG }} \\
\left({ }^{\circ} \mathbf{C}\right)\end{array}$ & $\begin{array}{c}\mathbf{T}_{\text {final decomposição }} \\
\left({ }^{\circ} \mathbf{C}\right)\end{array}$ & $\begin{array}{c}\text { Perda de massa } \\
2^{\circ} \text { estágio }(\%)\end{array}$ \\
\hline Hex 3 & - & 372 & 395 & 416 & 90 \\
\hline Hex 6 & - & 377 & 399 & 416 & 92 \\
\hline Hex 12 & - & 345 & 385 & 410 & 85 \\
\hline Benz 3 & 4,3 & 351 & 383 & 415 & 89 \\
\hline Benz 6 & - & 376 & 393 & 410 & 86 \\
\hline Benz 12 & - & 356 & 371 & 390 & 87 \\
\hline HexBenz 3 & - & 365 & 393 & 414 & 91 \\
\hline HexBenz 6 & - & 339 & 387 & 418 & 90 \\
\hline
\end{tabular}

A presença de grupos substituintes no esqueleto da celulose pode ocasionar variações de estabilidade térmica do biopolímero. No geral, ésteres mais substituídos podem apresentar maior estabilidade térmica (temperatura inicial de decomposição desloca-se para maiores temperaturas) (BARUD et al., 2008). Observa-se que para os ésteres com diferentes estruturas de grupo substituinte (hexanoatos e benzoatos), $\mathrm{T}_{\text {inicial }}$ diminuiu para o éster com grupo substituinte mais volumoso (benzoato). Provavelmente, ligações hidrogênio intermoleculares, realizadas pelos grupos hidroxila remanescentes foram mais intensas no grupo linear (hexanoatos), pela proximidade maior das cadeias vizinhas.

Observou-se um decréscimo da temperatura de pico de decomposição com o aumento da razão molar reagente/unidade anidroglicosídica, indicando menor estabilidade térmica (RODRIGUES, 2014). Conforme as hidroxilas na cadeia carbônica da celulose foram substituídas por grupos éster volumosos, ocorreu diminuição na quantidade de interações intermoleculares pelo afastamento das cadeias. Além disso, essas interações foram de menor intensidade comparadas às ligações hidrogênio existentes. A redução das interações intermoleculares ocasiona a diminuição do índice de cristalinidade dos ésteres. Assim, uma 
somatória de efeitos pode ser responsável pela tendência observada, tais como: a diminuição do número médio de hidroxilas ao longo do esqueleto celulósico, o que diminui o número de ligações hidrogênio ao longo da cadeia e a intensidade das ligações hidrogênio envolvendo hidroxilas, uma vez que a introdução de grupos volumosos causa uma maior separação das cadeias e consequentemente, reduz a cristalinidade.

\subsection{Preparação de Mantas via Eletrofiação}

\subsubsection{Mantas obtidas a partir de Soluções de Tetraidrofurano/Dimetilacetamida}

Soluções foram preparadas a partir dos hexanoatos de celulose, a fim de iniciar a exploração sobre melhores condições de eletrofiação. A voltagem utilizada e distância agulhacoletor e fluxo do solvente foram otimizados via testes. Soluções de benzoato de celulose e hexanoato-benzoato de celulose em THF/DMAc não eletrofiaram, desse modo o uso de outro solvente (ácido trifluoroacético) fez-se necessário (seção 4.3.2).

Os produtos obtidos que levaram a formação de mats eletrofiados foram caracterizados. Mantas que não levaram a produção de fibras, formaram filmes por eletropulverização, ou seja, formação de gotículas ou esferas de material que são pulverizadas em direção à superfície do coletor, em oposição ao material fibroso formado durante a eletrofiação. Isto ocorre quando a tensão superficial for elevada e/ou o entrelaçamento do polímero for baixo. À medida que a concentração do polímero aumenta, fibras com beads podem ser formadas (MITCHELL, 2015).

A morfologia da superfície das mantas obtidas a partir de soluções de ésteres de celulose foi investigada por Microscopia Eletrônica de Varredura.

A Figura 44 apresenta as micrografias obtidas a partir de mats de Hex 3. As mantas obtidas a partir de Hex 3 (9\%) com $10 \mathrm{~cm}$ de distância agulha-coletor, fluxo de injeção 5,5 $\mu \mathrm{L} \cdot \mathrm{min}^{-1}$ e tensão 15 e $20 \mathrm{kV}$ (Figura 44a,c) resultaram em fibras com muitas contas (beads) na estrutura. O termo fibras com contas é usado para fibras que têm a morfologia comum de pequenas contas ou pérolas, esféricas ou alongadas, espalhadas ao longo de seu comprimento. A presença de contas pode ser atribuída a baixa viscosidade da solução utilizada (MITCHELL, 2015) ou ao fenômeno de eletropulverização (COSTA et al., 2012). A média dos diâmetros obtidos com $15 \mathrm{kV}$ foi $168 \mathrm{~nm}$ e a média obtida com $20 \mathrm{kV}$ foi $166 \mathrm{~nm}$. No entanto, não se 
pode atribuir estes diâmetros somente às fibras, tendo em vista a presença de quantidade significativa de beads.

Figura 44. Micrografias de Hex3 nas seguintes condições: (a) $9 \%, 10 \mathrm{~cm}, 15 \mathrm{kV}$ e 5,5 $\mu \mathrm{m} \cdot \mathrm{min}^{-1}$; (b) $9 \%, 10 \mathrm{~cm}, 15 \mathrm{kV}$ e 15,5 $\mu \mathrm{m} \cdot \mathrm{min}^{-1}$; (c) $9 \%, 10 \mathrm{~cm}, 20 \mathrm{kV}$ e $5,5 \mu \mathrm{m} \cdot \mathrm{min}^{-1}$; (d) $11 \%, 15 \mathrm{~cm}, 15 \mathrm{kV}$ e $15,5 \mu \mathrm{m} \cdot \mathrm{min}^{-1}$; (e) $11 \%, 15 \mathrm{~cm}, 20 \mathrm{kV}$ e $15,5 \mu \mathrm{m} \cdot \mathrm{min}^{-1}$.
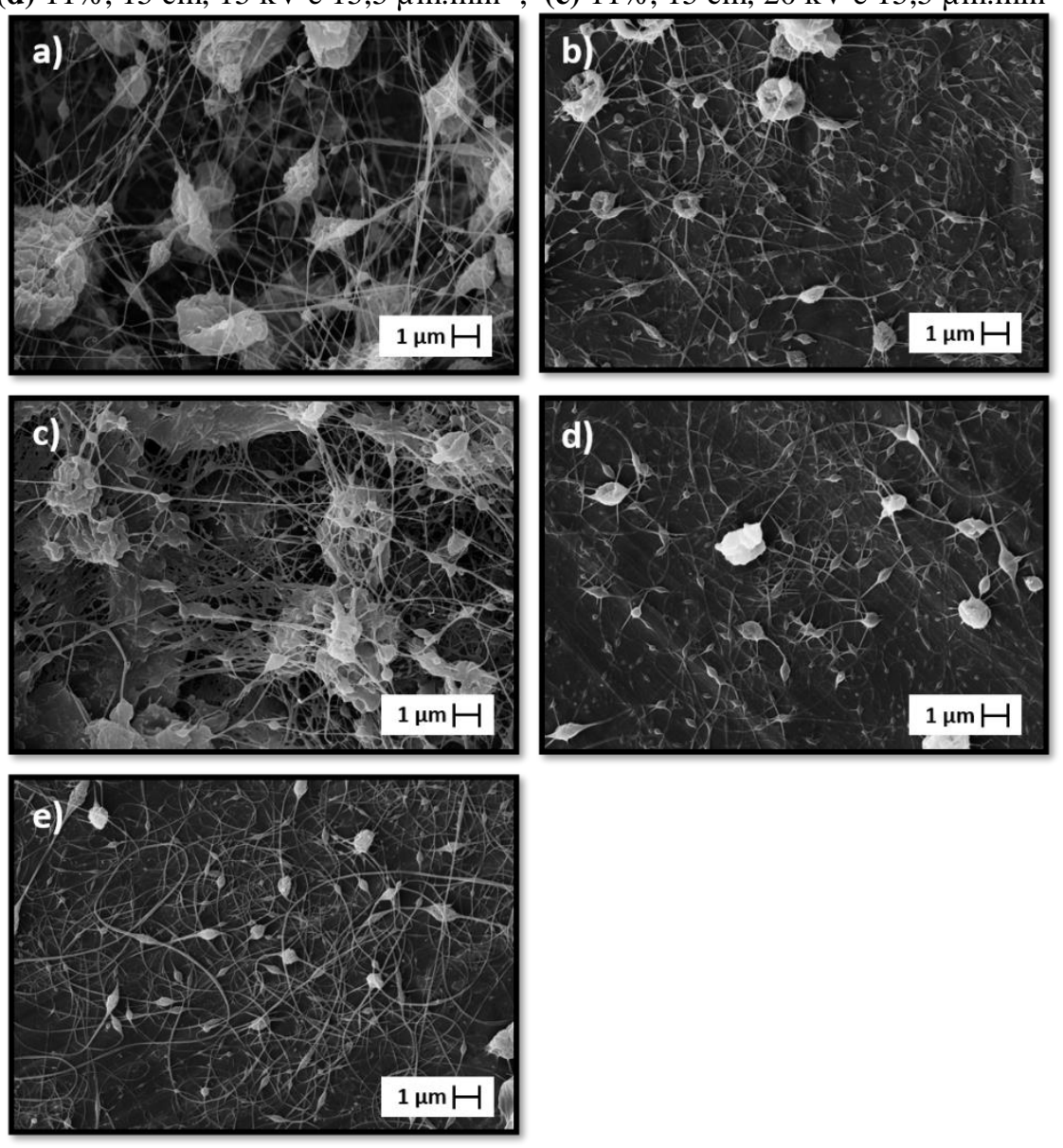

A Figura 44a apresenta mantas de Hex 3 (9\%) com 10 cm de distância agulha-coletor, tensão $15 \mathrm{kV}$ e fluxo de injeção de $5,5 \mu \mathrm{L} \cdot \mathrm{min}^{-1}$ em que notou-se formação de fibras com elevado número de beads com diâmetros variados. Para a micrografia do mat com as mesmas condições, exceto pela vazão mais elevada $\left(15,5 \mu \mathrm{L} \cdot \mathrm{min}^{-1}\right)$ (Figura 44b), observou-se menor número de beads e menor número de fibras apresentando diâmetro médio de $126 \mathrm{~nm}$. Comparando as micrografias da Figura 44a,b constatou-se que menor fluxo favoreceu fibras com menor diâmetro e os defeitos aparecem com menor intensidade nestas condições.

O aumento da concentração da solução de Hex 3 eletrofiada (11\%) nas seguintes condições distância de $15 \mathrm{~cm}$, voltagem de $15 \mathrm{kV}$ e vazão de $15,5 \mu \mathrm{m} \cdot \mathrm{min}^{-1}$ (Figura 44d) resultou em fibras com $150 \mathrm{~nm}$ de média de diâmetros e poucos defeitos nas mesmas. Um aumento na tensão aplicada $(20 \mathrm{kV})$ (Figura 44e) sob as mesmas condições levou a formação 
de uma maior quantidade de fibras assim como a diminuição do diâmetro médio das mesmas $(137 \mathrm{~nm})$ e a diminuição da presença de beads no mat.

A Figura 45 mostra os mats obtidos para amostras de Hex 6 eletrofiadas. A manta obtida a partir de amostra de Hex $6(9 \%)$ com $15 \mathrm{~cm}$ de distância agulha-coletor, tensão $15 \mathrm{kV}$ e fluxos de injeção $5,5 \mu \mathrm{L} \cdot \mathrm{min}^{-1}$ resultou em diâmetros com valor médio de $164 \mathrm{~nm}$ com muitos beads na estrutura (Figura 45a). Nas mantas obtidas a partir da mesma amostra com fluxos de injeção $15,5 \mu \mathrm{L} \cdot \mathrm{min}^{-1}$ (Figura 45b) não se observou a formação de fibras, sendo constituídas por um filme homogêneo e poroso.

Comparando micrografias de mats de Hex $6(11 \%)$ com distância de $10 \mathrm{~cm}$ e $15 \mathrm{kV}$ variando a vazão $\left(15,5\right.$ e 45,5 $\left.\mu \mathrm{L} \cdot \mathrm{min}^{-1}\right)$ (Figura 45c,d), constatou-se que maior fluxo de injeção favoreceu a formação de fibras com diâmetros menores assim como formação de um maior número de fibras. Em relação aos beads, observou-se uma elevação na quantidade em contrapartida com a diminuição do tamanho dos mesmos. Utilizando fluxo mais elevado (45,5 $\mu \mathrm{L} \cdot \mathrm{min}^{-1}$ ) observou-se a formação de fibras com diâmetro médio de $117 \mathrm{~nm}$, enquanto para um fluxo menor o diâmetro médio observado foi de $158 \mathrm{~nm}$.

Na Figura 45e,f,g, verifica-se as micrografias da mantas de Hex 6 concentração 11\% eletrofiadas a $10 \mathrm{~cm}$ de distância, $25 \mathrm{kV}$ de tensão aplicada e fluxo de injeção variado de 5,5 a 45,5 $\mu \mathrm{L} \cdot \mathrm{min}^{-1}$. Contatou-se que o aumento de vazão resultou em aumento do número de fibras, diminuição do diâmetro médio das fibras assim como a diminuição do número de contas.

O uso de elevados fluxos de injeção de amostra pode levar a fibras com maior quantidade de beads sendo maior a probabilidade de fibras serem depositadas no coletor sem a total evaporação do solvente durante a eletrofiação (PHAM; SHARMA; MIKOS, 2006). Tensões elevadas também podem levar a formação de beads nas mantas, visto que pode ocorrer a formação de uma gota na extremidade da agulha sem que ocorra a formação do cone de Taylor (PHAM; SHARMA; MIKOS, 2006). 
Figura 45. Micrografias de mats de Hex $6(9 \%)$ com $15 \mathrm{~cm}$ de distância, $15 \mathrm{kV}$ de tensão e fluxo de (a) 5,5 e (b) $15,5 \mu \mathrm{L} \cdot \mathrm{min}^{-1}$; Hex $6(11 \%)$ com $10 \mathrm{~cm}$ de distância, $15 \mathrm{kV}$ de tensão e fluxo de (c) 15,5 e (d) 45,5 $\mu \mathrm{m}^{\mathrm{min}} \mathrm{min}^{-1}$;

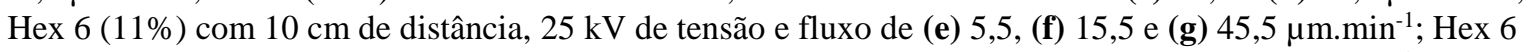
(11\%) com $10 \mathrm{~cm}$ de distância, $20 \mathrm{kV}$ de tensão e fluxo de (h) 5,5, (i) 15,5 e (j) 45,5 $\mu$ m.min ${ }^{-1}$.
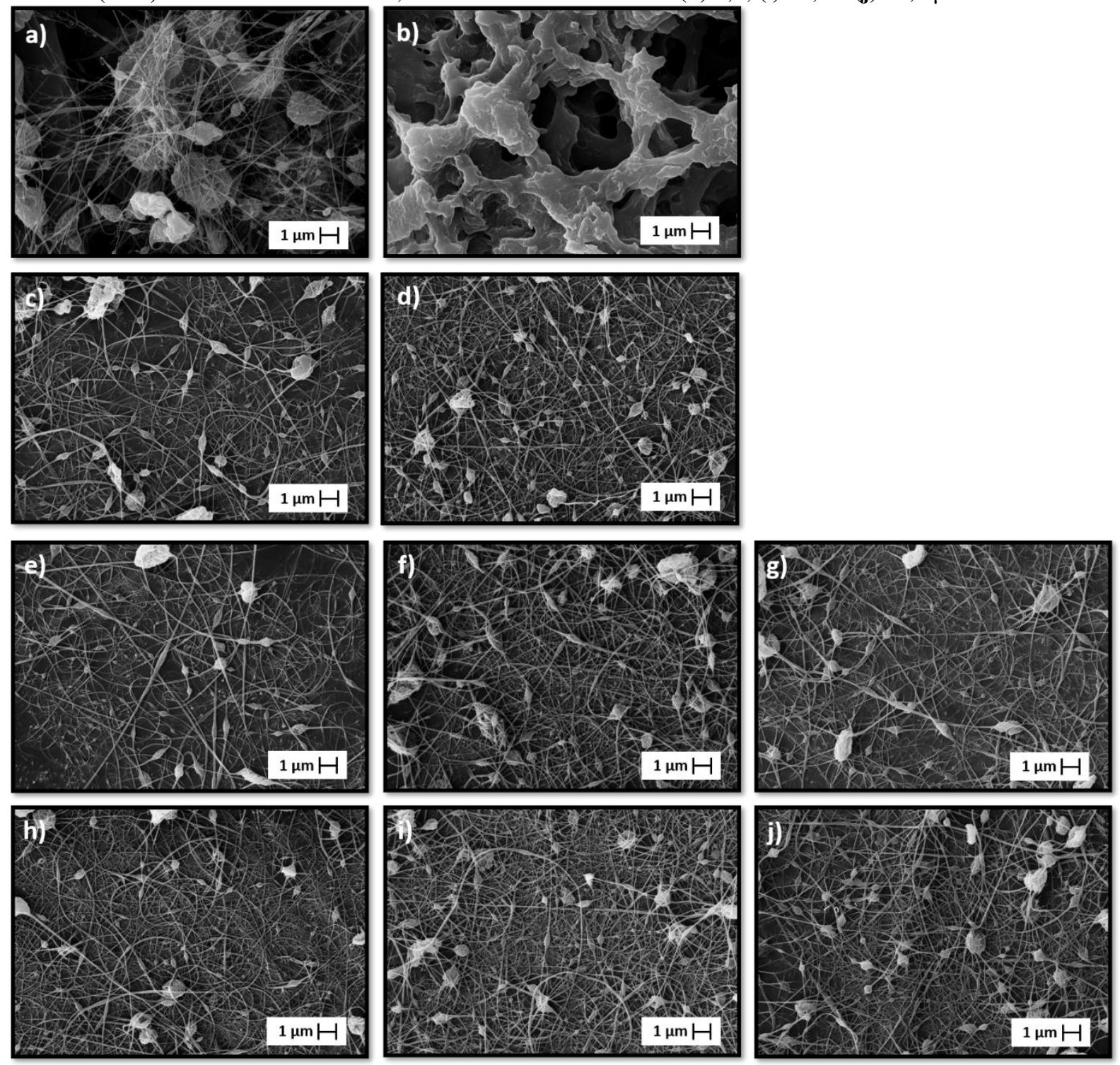

Comparando micrografias de mats de Hex 6 nas mesmas condições de processo $10 \mathrm{~cm}$ de distância, $20 \mathrm{kV}$ de tensão e 45,5 $\mu \mathrm{L} \cdot \mathrm{min}^{-1}$ de vazão, variando a concentração de $11 \%$ (Figura 46a) para 13\% (Figura 46b), constatou-se um aumento do diâmetro médio das fibras de $112 \mathrm{~nm}$ para $152 \mathrm{~nm}$. Foi observado também que o uso de uma menor concentração levou a ocorrência de beads menores e com menor frequência. 
Figura 46. Micrografias de mats de Hex 6 (a) 11\% e (b) 13\% nas condições:

$10 \mathrm{~cm}$ de distância, $20 \mathrm{kV}$ de tensão 45,5 $\mu \mathrm{L} \cdot \mathrm{min}^{-1}$.
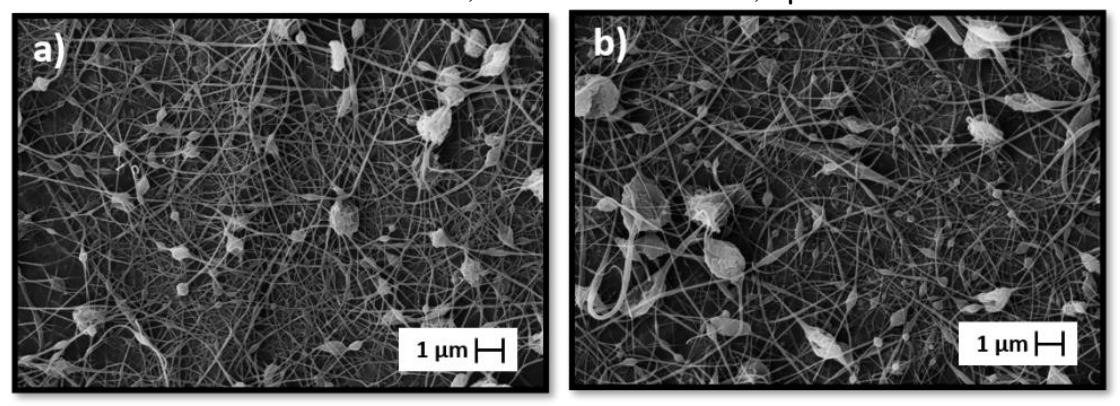

A fim de verificar a influência da voltagem aplicada na formação das fibras, comparouse as micrografias obtidas com variadas tensões. Na Figura 47a,b apresenta-se fibras de mats de Hex 6 (11\%) nas condições de $10 \mathrm{~cm}$ de distância, $5,5 \mu \mathrm{L} \cdot \mathrm{min}^{-1}$, tensão de $20 \mathrm{kV}$ e $25 \mathrm{kV}$. A menor voltagem $(20 \mathrm{kV})$ favoreceu uma maior formação de fibras sendo estas de menor diâmetro médio (111 nm) comparada a tensão de $25 \mathrm{kV}$ que apresentou diâmetro médio de 141 nm e menor formação de fibras. Em ambos as mantas foram observadas a presença de beads.

Figura 47. Micrografias de mats de Hex 6 (11\%) nas seguintes condições: $10 \mathrm{~cm}$ de distância, $5,5 \mu \mathrm{L} \cdot \mathrm{min}^{-1}$, tensão de (a) $20 \mathrm{kV}$ e (b) $25 \mathrm{kV} ; 10 \mathrm{~cm}$ de distância, 15,5 $\mu \mathrm{L} \cdot \mathrm{min}^{-1}$, tensão de (c) $15 \mathrm{kV}$, (d) $25 \mathrm{kV}$ e (e) $25 \mathrm{kV}$; $10 \mathrm{~cm}$ de distância, 45,5 $\mu \mathrm{L} \cdot \mathrm{min}^{-1}$, tensão de (f) $15 \mathrm{kV}$, (g) $25 \mathrm{kV}$ e (h) $25 \mathrm{kV}$;
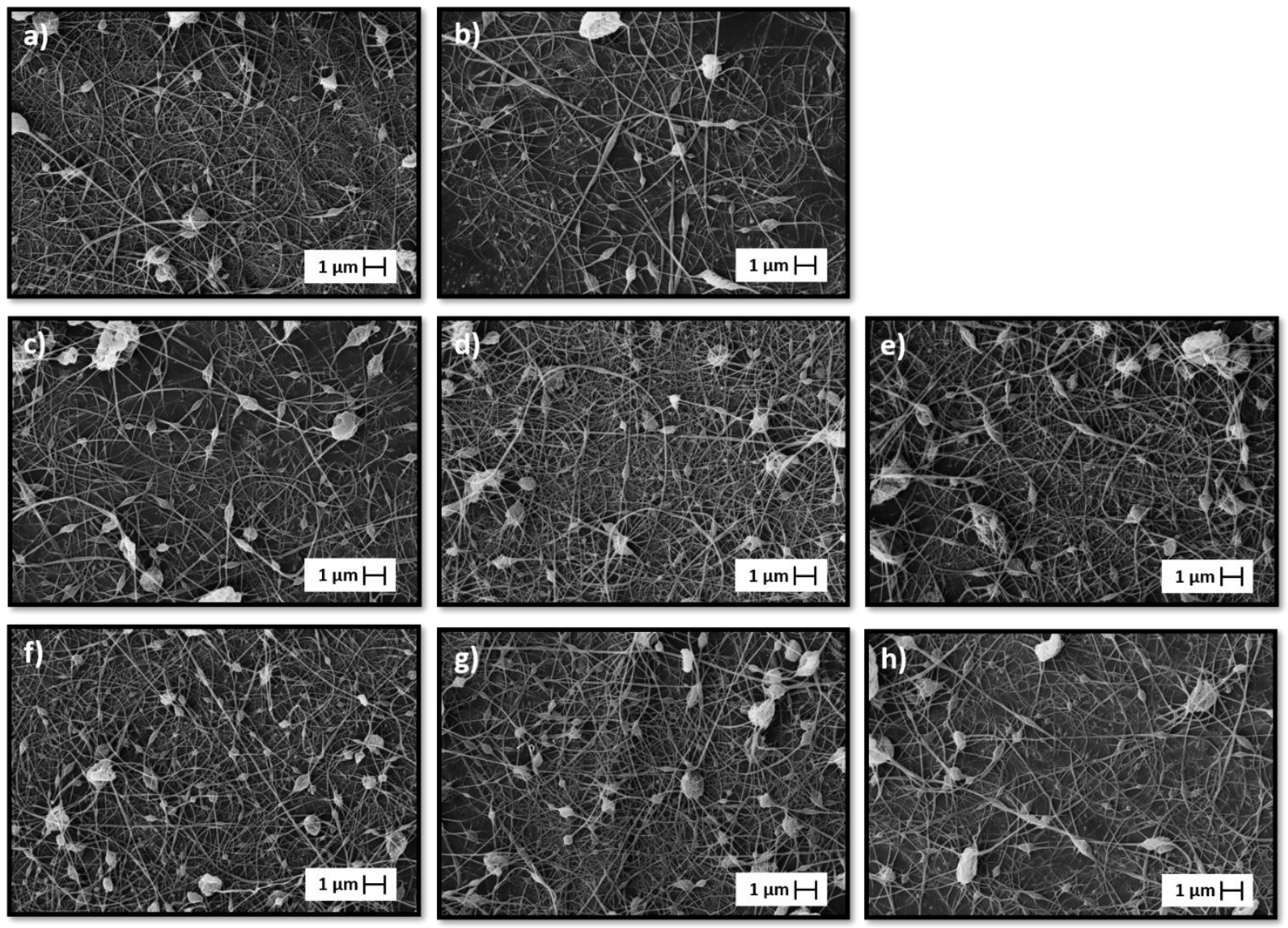
Comparando mats de amostras de Hex 6 (11\%) eletrofiadas a 10cm de distância, 15,5 $\mu \mathrm{L} \cdot \min ^{-1}$ de vazão e tensão de $15 \mathrm{kV}, 20 \mathrm{kV}$ e $25 \mathrm{kV}$ (Figura 47c,d,e), constatou-se que o aumento da tensão favoreceu a formação de fibras e favoreceu fibras de menores diâmetros sendo respectivamente $158 \mathrm{~nm}, 122 \mathrm{~nm}$ e $117 \mathrm{~nm}$. Em todos as mantas observou-se a presença de beads.

Para amostras de Hex 6 (11\%) nas condições de $10 \mathrm{~cm}$ de distância, fluxo de injeção de 45,5 $\mu \mathrm{L} \cdot \mathrm{min}^{-1}$ e voltagem de $15 \mathrm{kV}, 20 \mathrm{kV}$ e $25 \mathrm{kV}$ (Figura 47f,g,h), verificou-se o oposto, o aumento da tensão desfavoreceu a formação de fibras e favoreceu fibras de maiores diâmetros sendo respectivamente $117 \mathrm{~nm}, 112 \mathrm{~nm}$ e $130 \mathrm{~nm}$. Em todos os mats observou-se a presença de beads.

As mantas obtidas a partir da solução 7\% de Hex 12 utilizando as condições de $5 \mathrm{~cm}$ de distância, $25 \mathrm{kV}$ de tensão e fluxo de 45,5 $\mu \mathrm{L} \cdot \mathrm{min}^{-1}$ apresentaram majoritariamente beads (Figura 48a), com pequena formação de fibras (Figura 48a).

Figura 48. Micrografias de mats de Hex 12 (7\%) com (a) $5 \mathrm{~cm}$ de distância, $25 \mathrm{kV}$ de tensão e fluxo de 45,5 $\mu \mathrm{L} \cdot \mathrm{min}^{-1}$ e (b) $10 \mathrm{~cm}$ de distância, $15 \mathrm{kV}$ de tensão e fluxo de 5,5 $\mu \mathrm{m} \cdot \mathrm{min}^{-1}$.

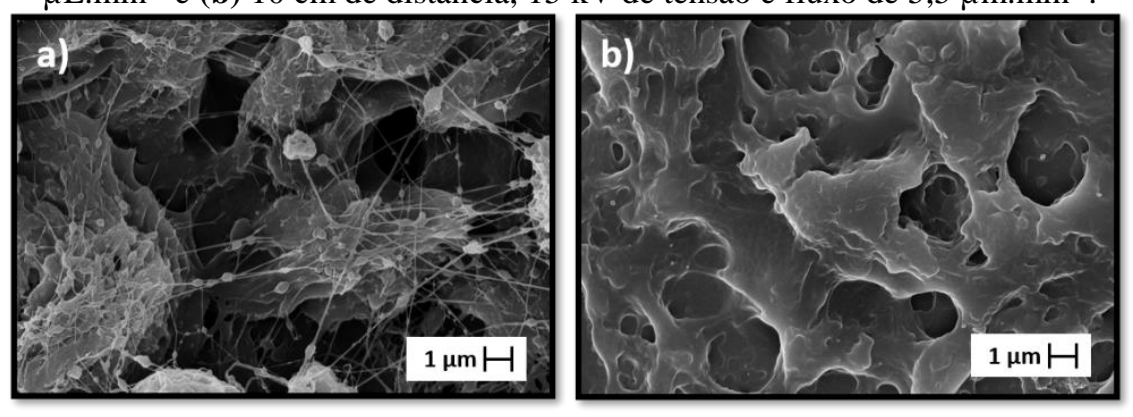

Este foi o único mat dentre as condições exploradas que resultou em formação de fibras, os demais mats originaram filmes porosos (Figura 48b).

A fim de verificar se o processo de eletrofiação promoveu alguma alteração na estrutura dos ésteres de celulose, espectros na região do infravermelho foram obtidos realizada. Comparando o espectro do éster com o espectro do respectivo mat foi observado o mesmo padrão de bandas (espectros não mostrados). 


\subsubsection{Mantas produzidas a partir de Soluções de Ácido Trifluoroacético}

Visto que não houve formação de fibras na eletrofiação de benzoato de celulose e ésteres mistos de hexanoato-benzoato de celulose no sistema de solvente THF/DMAc, foi utilizado o ácido trifluoroacético (TFA) como solvente. O TFA é um ácido organofluorado usado na eletrofiação de celulose e derivados devido a sua elevada força ácida, alta volatilidade e miscibilidade com uma vasta gama de solventes orgânicos (HOIK et al., 2018; DE OLIVEIRA SANTOS; RAMOS; FROLLINI, 2019).

Os grupos hidroxila dos ésteres de celulose podem sofrer esterificação por ação do solvente TFA utilizado. O TFA pode agir como um catalisador ácido neste tipo de reação (Figura 49). Nesse caso, os espectros de FTIR com picos na região de $1790 \mathrm{~cm}^{-1}$ (absorção do carbonil dos grupos trifluoroacetil) seriam obtidos.

Figura 49. Reação de esterificação do benzoato de celulose por ácido trifluoroacético.

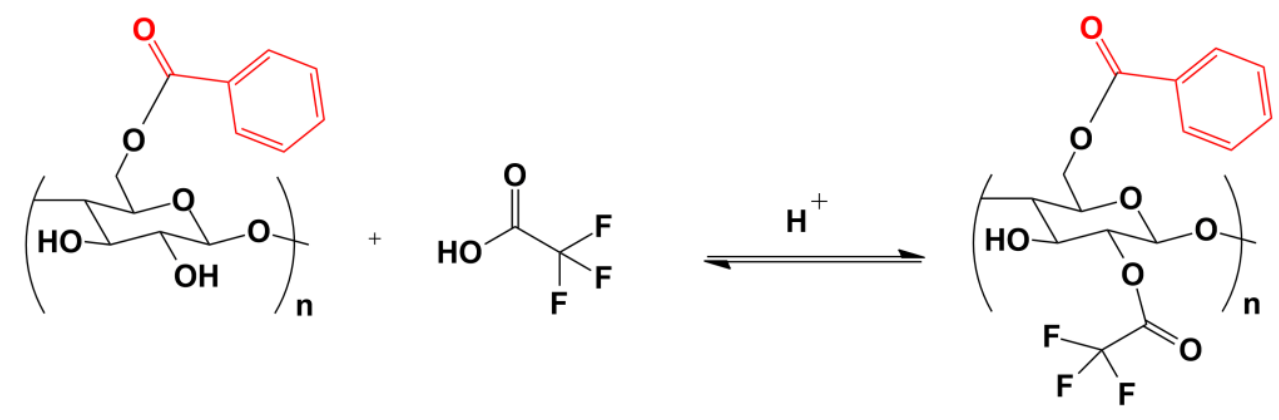

Fonte: autoria própria.

A fim de verificar se houve esterificação do éster de celulose pelo ácido trifluoroacético, foram obtidos os espectros na região do infravermelho para os mats de benzoato de celulose, assim como de ésteres mistos.

Como observado nos espectros, houve esterificação pela ação do TFA apenas para os mats de Benz 12, como confirmado pelo pico pouco intenso na região de $1790 \mathrm{~cm}^{-1}$, o qual pode ser atribuído à absorção das carbonilas dos grupos trifluoroacetato (Figura 50).

Foi reportado por Rodrigues et al. e também Montaño-Leyva et al., que mats de celulose obtidos por eletrofiação, a partir do uso de TFA como solvente, apresentaram uma banda em $1790 \mathrm{~cm}^{-1}$ nos espectros de infravermelho, devido às carbonilas dos grupos trifluoracetilas. Entretanto, nesse mesmo estudo, foi relatado que com a exposição dos mats a umidade do ar a banda referente às carbonilas dos grupos trifluoracetato desapareceu, devido à 
hidrólise deste grupo éster, o que regenera os grupos hidroxila, (MONTAÑO-LEYVA et al., 2011; RODRIGUES et al., 2015).

Figura 50. Espectros na região do infravermelho para mats de benzoato de celulose e éster misto.

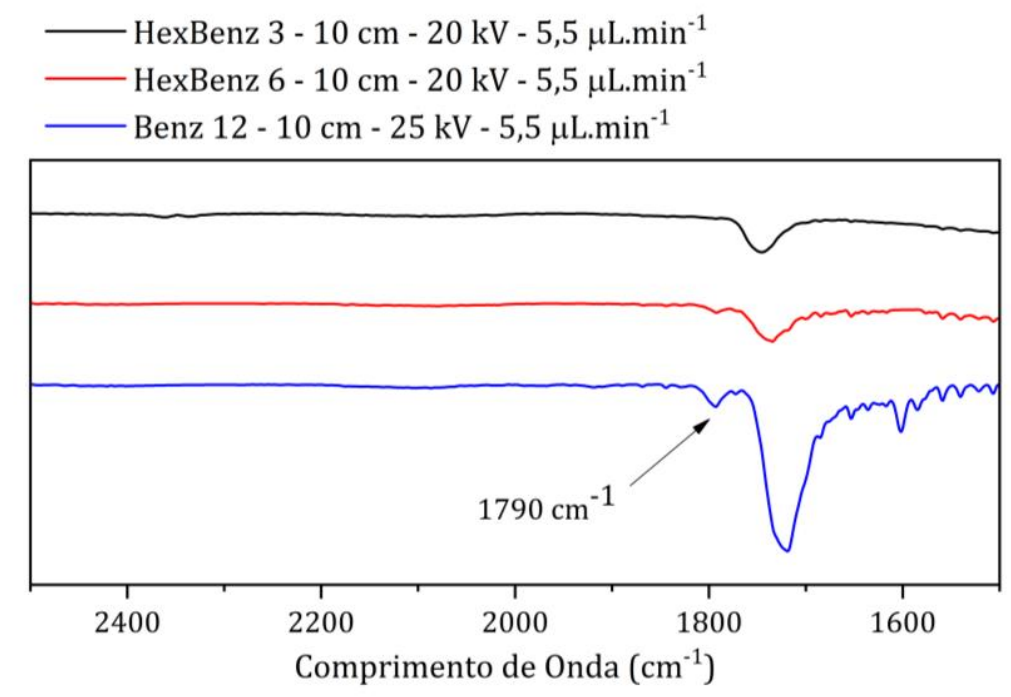

A Figura 51 apresenta as micrografias obtidas para benzoato de celulose razão molar 12 com concentração 9\% em massa em ácido trifluoroacético. A manta eletrofiada a partir de Benz 12 a 10cm de distância, $20 \mathrm{kV}$ de tensão e fluxo de injeção de 5,5 $\mu \mathrm{L} \mathrm{min}^{-1}$ (Figura 51a) resultou em fibras com diâmetro médio de $151 \mathrm{~nm}$ e beads na estrutura. Os mats apresentaram distribuição heterogênea de fibras sendo diâmetros variados de 37 a $428 \mathrm{~nm}$. Aumentando o fluxo para 15,5 $\mu \mathrm{L} \cdot \mathrm{min}^{-1}$ e mantendo as demais condições (Figura 51b), notou-se que não houve variação do diâmetro médio de fibras $(150 \mathrm{~nm})$. A manta também apresentou amplo intervalo de diâmetro de fibras (de $36 \mathrm{~nm}$ a $463 \mathrm{~nm}$ ), mas observou-se maior formação de fibras e menor número de defeitos na estrutura.

A Figura 51c apresenta a micrografia do mat de Benz 12 (9\% em TFA) nas condições de $10 \mathrm{~cm}$ de distância, voltagem de $25 \mathrm{kV}$ e vazão de solução de 5,5 $\mu \mathrm{L}$. $\mathrm{min}^{-1}$. Observou-se poucos defeitos e diâmetros de fibras médios de $138 \mathrm{~nm}$. Comparando a Figura 51a,c, notouse que o aumento do tensão aplicada favoreceu a diminuição do diâmetro médio de fibras assim como a diminuição de defeitos na manta. 
Figura 51. Micrografias e histogramas de distribuição de fibras de mantas de Benz 12 (9\% em TFA) com distância de $10 \mathrm{~cm}$ nas seguintes condições: (a) $20 \mathrm{kV}$ de tensão e $5,5 \mu \mathrm{L} \cdot \mathrm{min}^{-1}$ de vazão; (b) $20 \mathrm{kV}$ de tensão e $15,5 \mu \mathrm{L} \cdot \mathrm{min}^{-1}$ de vazão; (c) $25 \mathrm{kV}$ de tensão e $5,5 \mu \mathrm{L} \cdot \mathrm{min}^{-1}$ de vazão; (d) $25 \mathrm{kV}$ de tensão e $15,5 \mu \mathrm{L} \cdot \mathrm{min}^{-1}$ de vazão.
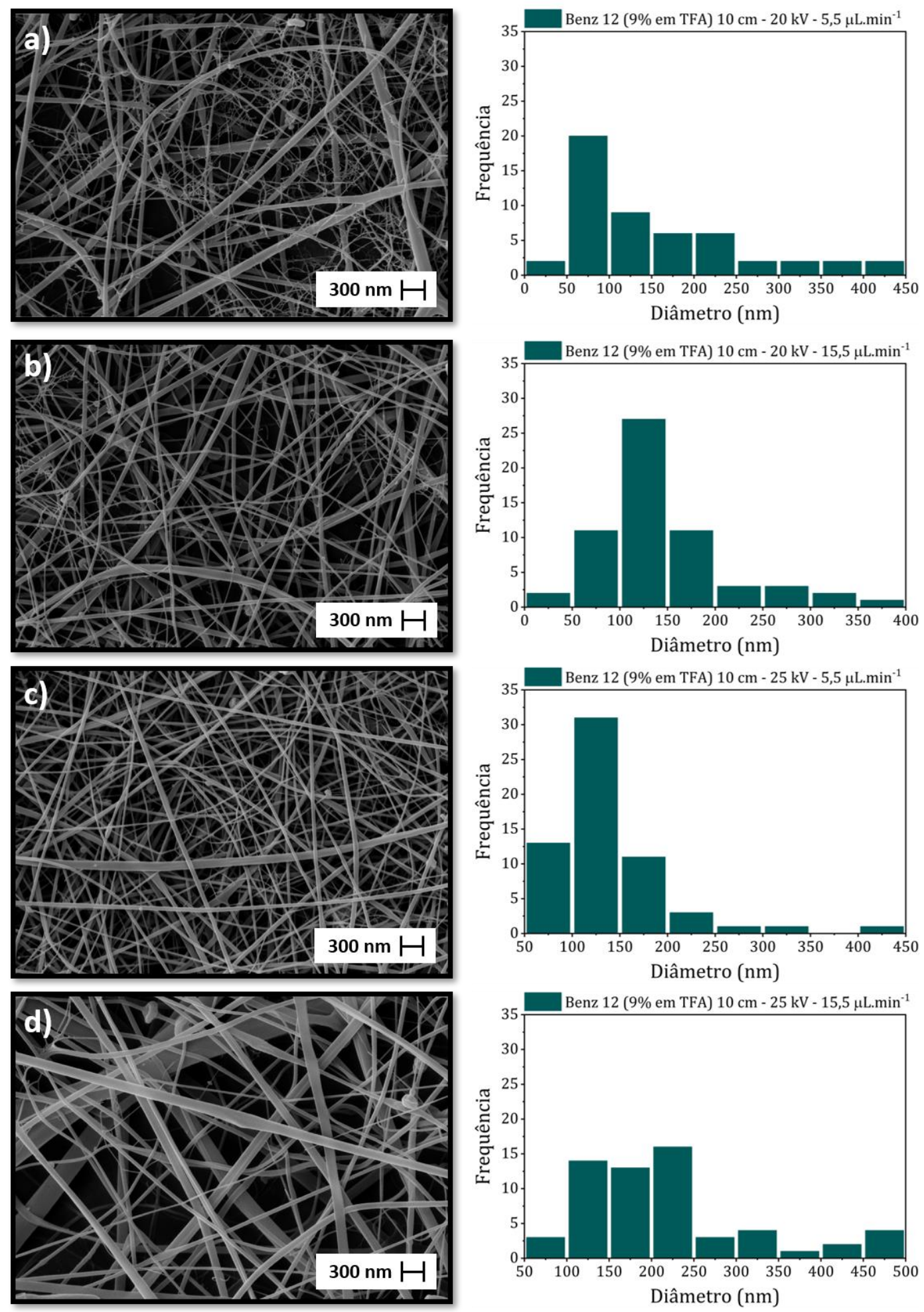

Para a amostra de Benz 12 com distância do coletor de $10 \mathrm{~cm}$, voltagem aplicada de $25 \mathrm{kV}$ e vazão da solução de 15,5 $\mu \mathrm{L} \cdot \mathrm{min}^{-1}$, verificou-se formação de fibras com diâmetro médio de $228 \mathrm{~nm}$ e pequenas quantidades de beads na estrutura (Figura 51d). Comparando a 
Figura 51b,d na mesma condição alterando a tensão de $20 \mathrm{kV}$ para $25 \mathrm{kV}$, constatou-se que a diminuição da tensão aplicada favoreceu a formação de fibras com menores diâmetros. Para as mantas mostradas na Figura 47 foram gerados os histogramas referentes a distribuição de diâmetros de fibras, pois a ampla predominância de fibras em relação às contas faz com que os histogramas de fato representem dimensões das fibras.

A Figura 52 representa as micrografias obtidas para ésteres mistos com concentração 9\% em massa em ácido trifluoroacético. Observou-se a ocorrência de fibras em elevada quantidade e com poucas formações de defeitos (beads) para a eletrofiação de amostras de HexBez 3 com $10 \mathrm{~cm}$ de distância, $20 \mathrm{kV}$ de tensão e fluxo de injeção de 5,5 $\mu \mathrm{L} \cdot \mathrm{min}^{-1}$ (Figura 52a). Comparativamente, aumentando o fluxo para $15,5 \mu \mathrm{L} \cdot \mathrm{min}^{-1}$, notou-se diminuição dos defeitos e elevação do diâmetro médio de fibras (de $77 \mathrm{~nm}$ para $85 \mathrm{~nm}$ ) (Figura 52a,b). Assim, o aumento do fluxo de injeção de solução favoreceu a diminuição de defeitos na manta. Comparando amostras de (Figura 52a,c) mats de HexBez $3 \mathrm{com} 10 \mathrm{~cm}$ de distância e fluxo de injeção de 5,5 $\mu \mathrm{L} \cdot \mathrm{min}^{-1}$ variando a tensão (de 20 para $25 \mathrm{kV}$ ), observou-se formação de fibras com diâmetros mais variados e maior quantidade de beads nas superfícies da manta. Desse modo, uma menor voltagem no sistema favoreceu a formação de fibras com diâmetros mais próximos e favorece também a diminuição dos beads.

Para a amostra de éster misto com uma maior razão molar (HexBenz 6) com distância do coletor de $10 \mathrm{~cm}$, voltagem aplicada de $20 \mathrm{kV}$ e vazão da solução de $5,5 \mu \mathrm{L} \cdot \mathrm{min}^{-1}$, verificouse baixa formação de fibras sendo estas de diâmetro reduzido (67 nm média) e predominância de beads na estrutura (Figura 52d).

Com o aumento da vazão da solução de HexBenz 6 para 15,5 $\mu \mathrm{L} \cdot \mathrm{min}^{-1}$, e mantendo os demais parâmetros, constatou-se a formação de esferas com diâmetro médio de 2,5 $\mu \mathrm{m}$, não havendo qualquer indício de formação de fibras (Figura 52e). Desse modo, uma menor vazão de solução favoreceu a formação de fibras e diminuição de beads na estrutura. Comparando as micrografias de mats de HexBenz 6 com distância de $10 \mathrm{~cm}$ e fluxo de 15,5 $\mu$ L.min ${ }^{-1}$ mas alterando a tensão aplicada de 20 para $25 \mathrm{kV}$ (Figura 52e,f), observou-se o início da formação de fibras em pequenas quantidades com diâmetros médios de $75 \mathrm{~nm}$ mas com predominância de beads na manta. Assim, o aumento da tensão favoreceu a formação de fibras e diminuição de defeitos. Os histogramas foram gerados somente para as mantas em que a formação de fibras (Figura 52a,b) ou de esferas (Figura 52e) foi predominante. 
Figura 52. Micrografias e histogramas de distribuição de fibras de ésteres mistos de celulose $9 \%$ em TFA, com 10 cm de distância nas seguintes condições: (a) HexBenz 3 com $20 \mathrm{kV}$ de tensão e 5,5 $\mu \mathrm{m} . \mathrm{min}^{-1}$;

(b) HexBenz 3 com $20 \mathrm{kV}$ de tensão e 15,5 $\mu \mathrm{m} \cdot \mathrm{min}^{-1}$; (c) HexBenz $3 \mathrm{com} 25 \mathrm{kV}$ de tensão e 5,5 $\mu \mathrm{m} . \mathrm{min}^{-1}$;

(d) HexBenz 6 com $20 \mathrm{kV}$ de tensão e 5,5 $\mu \mathrm{m} \cdot \mathrm{min}^{-1}$; (e) HexBenz 6 com $25 \mathrm{kV}$ de tensão e 5,5 $\mu \mathrm{m} \cdot \mathrm{min}^{-1}$; (f) HexBenz $6 \mathrm{com} 25 \mathrm{kV}$ de tensão e $15,5 \mu \mathrm{m} \cdot \mathrm{min}^{-1}$.
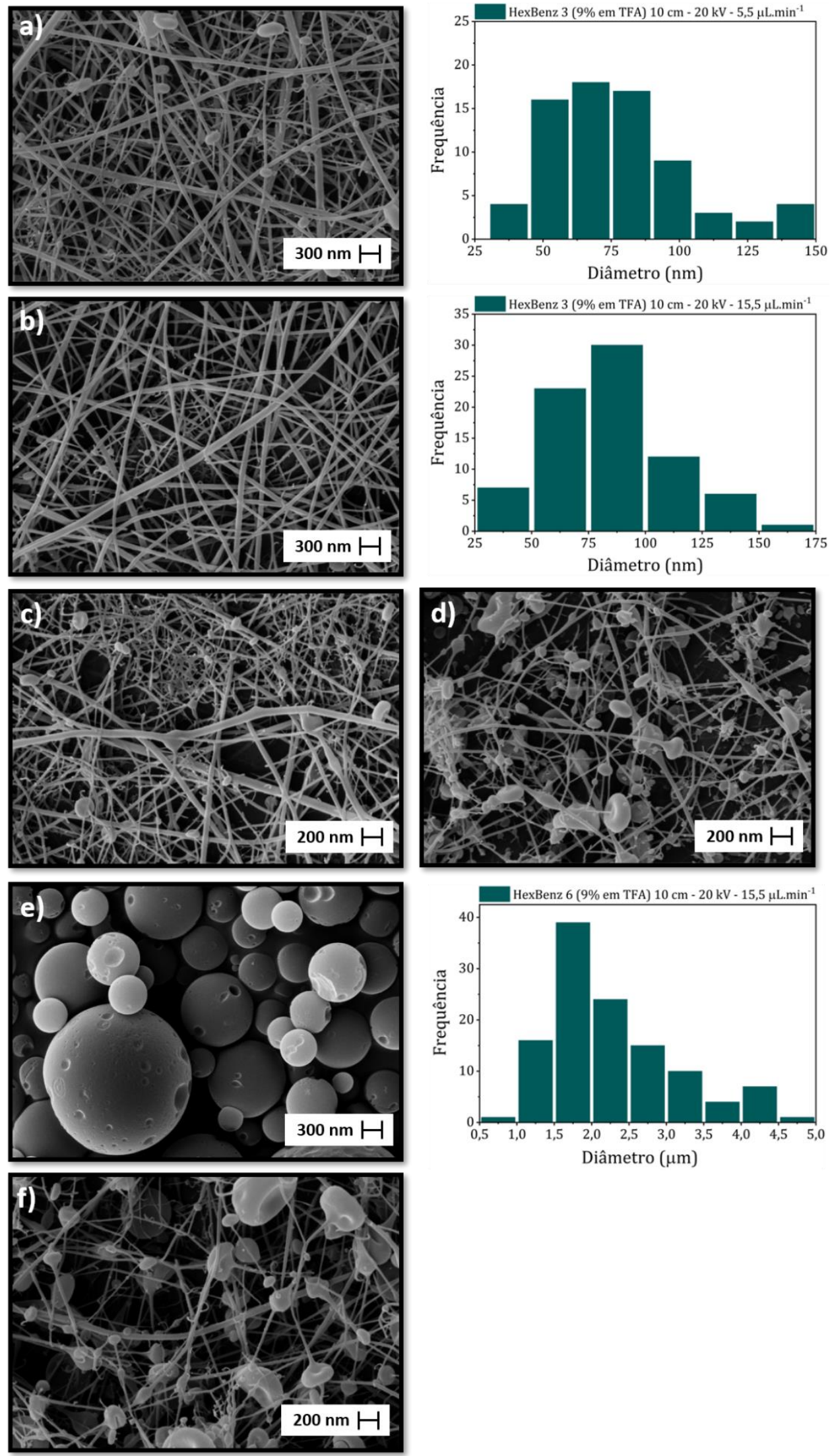


\subsection{1 Ângulo de Contato}

Os valores de ângulo de contato têm sido frequentemente utilizados para caracterizar propriedades de superfície, tais como caráter hidrofílico, rugosidade e heterogeneidade (GOMES et al., 2007; RODRIGUES, 2014).

Foram realizadas medidas de ângulo de contato para os mats de ésteres de celulose preparados por eletrofiação e, a partir das imagens (Figura 53), foram obtidos os valores de ângulo de avanço (máximo) e ângulo de recuo (mínimo), assim como os valores de histerese (diferença entre os ângulos mencionados). Os valores supracitados estão descritos na Tabela 13.

Tabela 13. Ângulo de avanço, recuo e histerese para mats de ésteres de celulose.

\begin{tabular}{|c|c|c|c|c|c|c|c|}
\hline Amostra & $\begin{array}{c}\text { Concentração } \\
(\%)\end{array}$ & $\begin{array}{c}\text { Distância } \\
\text { (cm) }\end{array}$ & $\begin{array}{c}\text { Voltagem } \\
(\mathrm{kV})\end{array}$ & $\begin{array}{c}\text { Fluxo } \\
\left(\mu \mathrm{m}^{\prime} \mathbf{m i n}^{-1}\right)\end{array}$ & $\begin{array}{l}\text { Ângulo de } \\
\text { Avanço }\left({ }^{\circ}\right)\end{array}$ & $\begin{array}{l}\text { Ângulo de } \\
\text { Recuo }\left({ }^{\circ}\right)\end{array}$ & $\begin{array}{c}\text { Histerese } \\
\left(^{\circ}\right)\end{array}$ \\
\hline$\overline{\operatorname{Hex} 3}$ & 11 & 15 & 20 & 15,5 & $124 \pm 3$ & $118 \pm 4$ & $5 \pm 1$ \\
\hline Hex 6 & 11 & 10 & 20 & 15,5 & $146 \pm 5$ & $142 \pm 4$ & $3 \pm 1$ \\
\hline Hex 12 & 7 & 10 & 15 & 5,5 & $110 \pm 8$ & $106 \pm 6$ & $4 \pm 1$ \\
\hline Benz 12 & 9 & 10 & 20 & 15,5 & $83 \pm 3$ & $42 \pm 5$ & $41 \pm 8$ \\
\hline HexBenz 3 & 9 & 10 & 20 & 15,5 & $126 \pm 3$ & $121 \pm 3$ & $2 \pm 2$ \\
\hline HexBenz 6 & 9 & 10 & 20 & 15,5 & $134 \pm 2$ & $131 \pm 3$ & $6 \pm 2$ \\
\hline
\end{tabular}

Podem ser observados valores superiores de ângulos de avanço e ângulo de recuo $\left(>90^{\circ}\right)$ para todos os mats de éster exceto para manta de Benz 12. Os valores encontrados indicam que os mats apresentaram baixa interação com a água (RODRIGUES, 2014) apontando para um caráter hidrofóbico (Figura 53a). Estes resultados indicaram que as hidroxilas não substituídas estavam predominantemente voltadas para o interior dos mats, provavelmente envolvidas em ligações hidrogênio, sendo as superfícies principalmente constituídas por regiões hidrofóbicas.

Para amostras de Benz 12, o contato entre a superfície da manta e a gota de água foi intenso levando a um decréscimo acentuado do ângulo de contato e um elevado valor de histerese em um curto intervalo de tempo (Figura 53b). O ângulo de avanço foi de $83^{\circ}$ e o ângulo de recuo foi de $42^{\circ}$, levando a um valor de histerese de $41^{\circ}$. Valores de ângulos de contato $<90^{\circ}$ indicaram interação com a água (RODRIGUES, 2014) e caráter hidrofílico. Este fato indicou que as hidroxilas não substituídas estavam predominantemente voltadas para o exterior dos mat. 
Figura 53. Imagens de ângulo de contato para (a) mat de Hex $6(11 \%)$ com $10 \mathrm{~cm}$ de distância entre agulhacoletor, $20 \mathrm{kV}$ de tensão e 15,5 $\mu \mathrm{L} \cdot \mathrm{min}^{-1}$; (b) mat de Benz $12 \mathrm{com} 10 \mathrm{~cm}$ de distância entre agulha-coletor, 20 $\mathrm{kV}$ de tensão e $15,5 \mu \mathrm{L} \cdot \mathrm{min}^{-1}$.
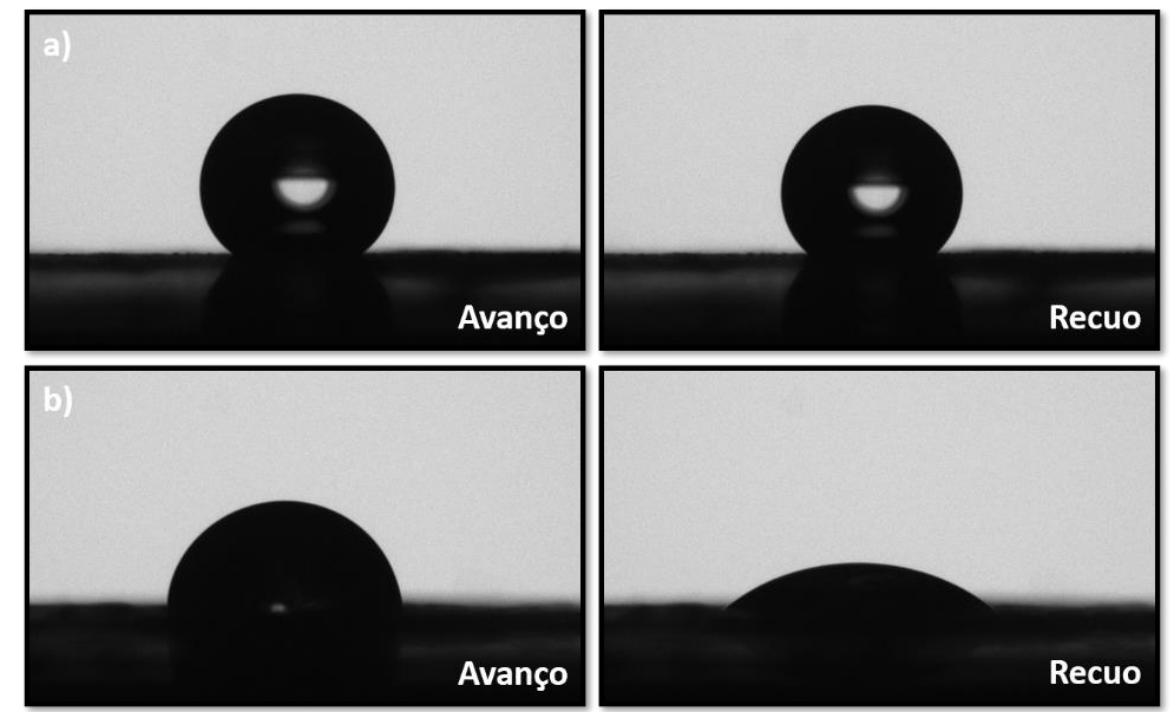

Para Hex 6 observou-se pouca variação entre os ângulos de contato de recuo e avanço, sendo o valor de avanço de $146^{\circ}$ e o valor de recuo de $142^{\circ}$, indicando que houve pouca interação entre a gota de água e manta ao longo do tempo.

O ângulo de avanço foi $126^{\circ}$ e o de recuo $121^{\circ}$ para a manta de HexBenz 3. Para mantas de HexBenz 6, o ângulo de avanço foi $134^{\circ}$ e o de recuo $131^{\circ}$, com histereses de $2^{\circ}$ e $6^{\circ}$, respectivamente.

Mikaeli e Gouma reportaram a preparação de mats de acetato de celulose eletrofiados com ângulo de contato com a água superiores a $90^{\circ}\left(154,3^{\circ}\right)$ obtendo materiais super hidrofóbicos (MIKAEILI; GOUMA, 2018). Um material pode ser classificado como super hidrofóbico se exibir um ângulo aparente de contato com a água de mais de $150^{\circ}$ e valor de histerese baixo (BARTHLOTT et al., 2005). 


\subsection{Preparação de Esferas}

Soluções foram preparadas a partir de soluções dos ésteres de celulose (5\%, acetona), com exceção de Benz 3 que não houve formação de esferas, e moldadas em esferas por meio de gotejamento, conforme descrito na seção 3.7.2 (Figura 54).

Figura 54. Imagens de esferas Hex 6 (a) úmidos e (b) secos
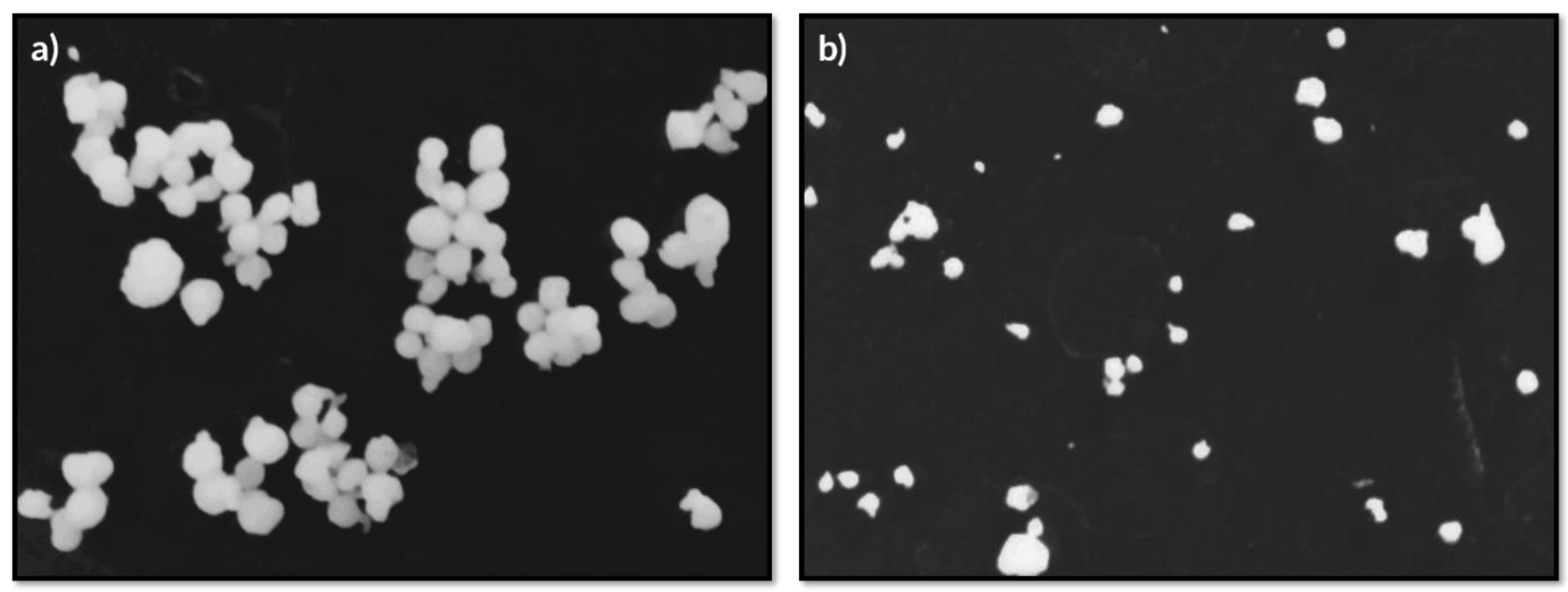

\subsubsection{Caracterização das Esferas}

As micrografias na Figura 55 apresentam a morfologia das superfícies das esferas de hexanoato de celulose. As esferas apresentaram formato esférico não uniforme e a superfícies predominantemente rugosa. Esferas preparadas utilizando metanol como não-solvente exibiram contração durante o processo de secagem, havendo assim uma redução no diâmetro das esferas. Em contrapartida, as esferas preparadas utilizando água como não-solvente, apresentaram diâmetros maiores visto que não sofreram encolhimento na secagem. Os diâmetros médios para esferas foram analisados com paquímetro digital e resultaram em 2,5 mm, 1,8 mm e 2,4 mm para amostras de Hex 3, Hex 6 e Hex 12 em água, respectivamente, e os diâmetros obtidos para esferas de amostras de Hex 3, Hex 6 e Hex 12 em metanol foram respectivamente, 1,5 mm, 1,0 mm e 1,2 mm (Tabela 14). 
A Figura 55 apresenta imagem que destaca a rugosidade superficial (textura ou relevo) obtidas pelo processamento das micrografias da superfície das esferas por meio do software Fiji (ImageJ) utilizando o plugin SurfCharJ. As cores claras evidenciam partes da superfície da esfera em maior relevo, portanto maior rugosidade. Em contrapartida cores mais escuras evidenciam partes da superfície da esfera em baixo relevo, portanto menor rugosidade

Tabela 14. Diâmetro médio e rugosidade média das esferas de ésteres de celulose.

\begin{tabular}{cccc}
\hline Amostra & Solvente & $\begin{array}{c}\text { Diâmetro } \\
(\mathbf{m m})\end{array}$ & $\begin{array}{c}\text { Rugosidade } \\
\text { média }(\boldsymbol{\mu m})\end{array}$ \\
\hline Hex 3 & água & $2,5 \pm 0,2$ & 15,1 \\
& metanol & $1,5 \pm 0,2$ & 34,2 \\
Hex 6 & água & $1,8 \pm 0,2$ & 24,9 \\
& metanol & $1,0 \pm 0,1$ & 32,4 \\
Hex 12 & água & $2,4 \pm 0,2$ & 24,8 \\
& metanol & $1,2 \pm 0,1$ & 17,2 \\
Benz 6 & água & $2,2 \pm 0,4$ & 31,3 \\
Benz 12 & água & $3,3 \pm 0,4$ & 13,5 \\
HexBenz 3 & água & $2,0 \pm 0,2$ & 25,7 \\
HexBenz 6 & água & $2,6 \pm 0,2$ & 36,8 \\
\hline
\end{tabular}

A Tabela 14 apresenta os resultados de rugosidade média obtidos pelo processamento das micrografias da superfície das esferas por meio do software Fiji (ImageJ) utilizando o plugin SurfCharJ. De modo geral, observou-se que a rugosidade média de esferas produzidas em água como não-solvente foi menor que a de esferas produzidas em metanol. Ainda, esferas de ésteres com maior grau médio de substituição preparadas em metanol apresentaram menor rugosidade média quando comparados a ésteres com menor grau médio de substituição. 
Figura 55. Micrografias da superfície de esferas e respectiva micrografia da rugosidade de (a) Hex 3; (b) Hex 6 e (c) Hex 12 em metanol.
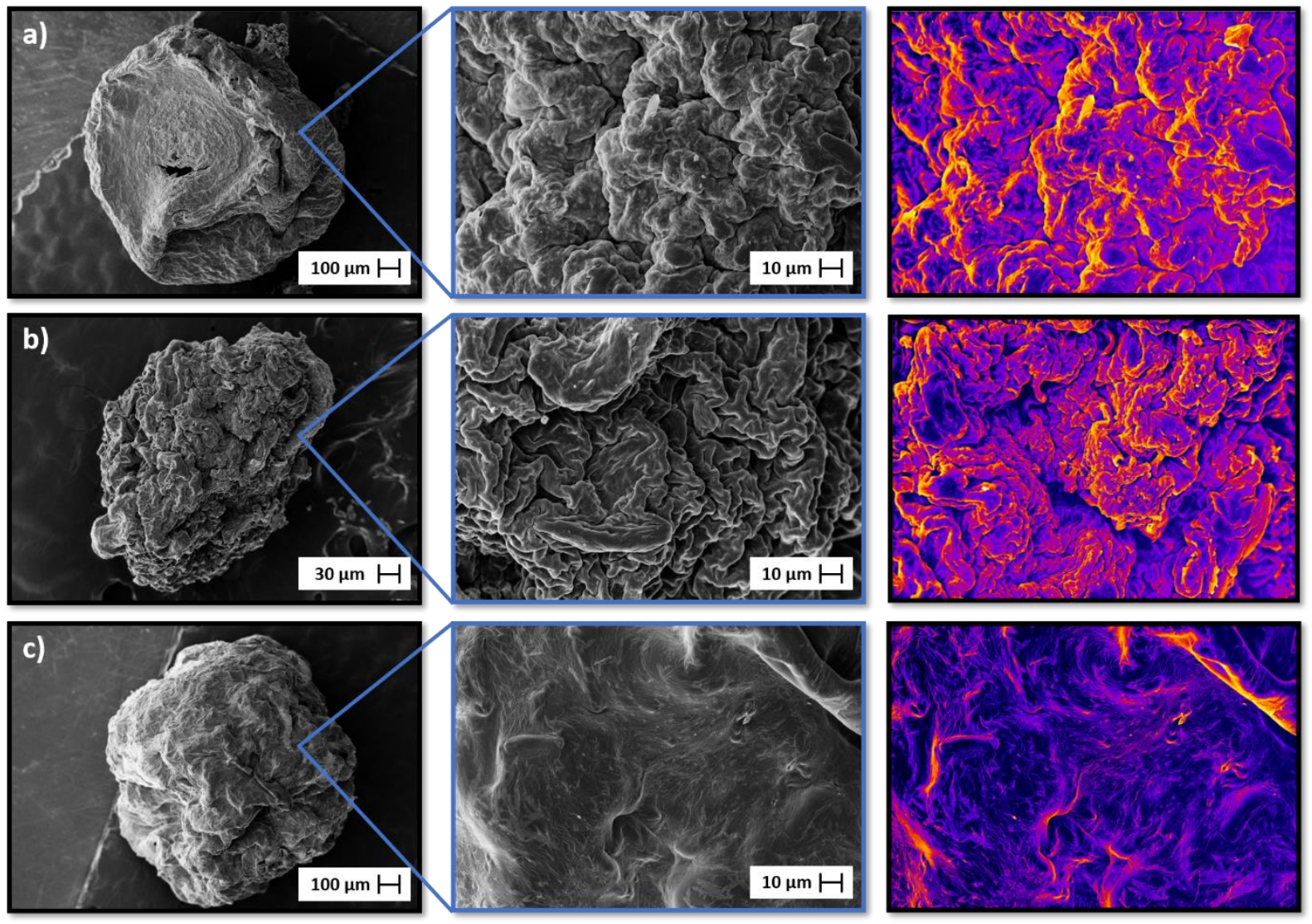

A Figura 56 apresenta as micrografias obtidas para esferas obtidas para amostras de Benz 6, HexBenz 3 e HexBenz 6. Os diâmetros médios encontrados foram 2,2 mm, 2,0 mm e 2,6 $\mathrm{mm}$ respectivamente. Em geral, o diâmetro das esferas de celulose obtidas pelas técnicas de gotejamento é limitado a um intervalo de aproximadamente 0,5 a $3 \mathrm{~mm}$, uma vez que é restrito ao tamanho das gotas que podem ser preparadas (GERICKE; TRYGG; FARDIM, 2013). Os formatos aproximadamente esféricos não foram uniformes, e as superfícies predominantemente rugosa. Ampliando a superfície rugosa em locais de fissuras ou defeitos, observou-se que o interior das esferas é composto por nanoesferas com diâmetros médios de $338 \mathrm{~nm}, 180 \mathrm{~nm}$ e $223 \mathrm{~nm}$, respectivamente. 
Figura 56. Micrografias de esferas de e respectiva micrografia da rugosidade de (a) Benz 6, (b) HexBenz 3 e (c) HexBenz 6 em metanol.
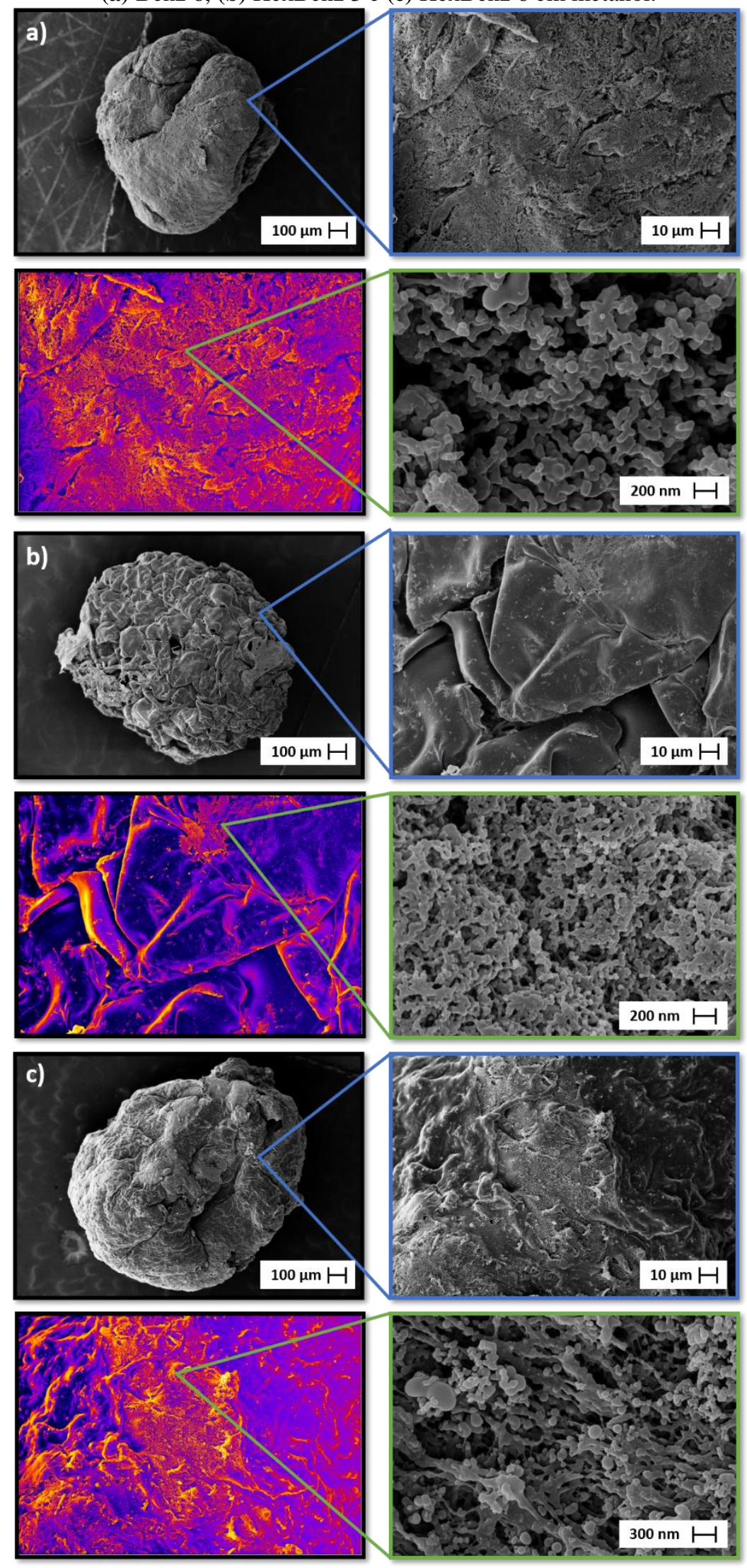
Esses resultados indicaram que a natureza dos ésteres, bem como o grau médio de substituição dos mesmos, interfere no tamanho médio das esferas obtidas.

\subsection{Imobilização de Lipases}

A fim de aplicar os materiais obtidos em reações biocatalíticas de cloridrinas racêmicas (R,S-2-cloro-1-feniletan-1-ol), foram preparadas mantas com lipase de Pseudomonas fluorescens (LPF) imobilizadas, a partir da eletrofiação de soluções de hexanoato de celulose. Benzoatos e hexanoatos-benzoatos de celulose não foram considerados para imobilização de lipases em mantas, visto que o solvente utilizado para a preparação das mesmas foi o ácido trifluoroacético, o que causaria degradação na lipase e perda de atividade.

Mats de Hex 6 foram preparados utilizando $50 \mathrm{mg}$ e $100 \mathrm{mg}$ de lipase Pseudomonas fluorescens, em solvente THF/DMAc nas seguintes condições: concentração de $11 \%, 10 \mathrm{~cm}$ de distância entre agulha-coletor, voltagem aplicada de $25 \mathrm{kV}$ e fluxo de injeção e solução de 15,5 $\mu \mathrm{L} \cdot \min ^{-1}$ (Figura 57a). Esta configuração experimental foi selecionada pelo fato de o mat ser composto por fibras ultrafinas com diâmetro médio de $117 \mathrm{~nm}$, pelo fluxo de injeção ser intermediário e apresentar quantidade não significativa de defeitos.

Para a imobilização da enzima em esferas, soluções foram preparadas a partir dos ésteres de celulose e lipase de Pseudomonas fluorescens em acetona (3 mL) com agitação, a temperatura ambiente. A concentração em massa do éster de celulose em solução foi 5\% (330 mg) e quantidades variadas de lipase (50 e $100 \mathrm{mg}$ ). A solução foi gotejada sobre nitrogênio líquido com uma pipeta Pasteur de $3 \mathrm{~mL}$ descartável. Após congeladas, as esferas foram vertidas sobre água ou metanol a fim de descongelar. Posteriormente as esferas foram secas a temperatura ambiente por um período de $48 \mathrm{~h}$.

Esferas de Hex 6 (30\% de lipase), Hex 6 (15\% de lipase) e Hex 12 (15\% de lipase) foram preparados utilizando metanol como não-solvente (Figura 57b) e, esferas de Hex 6 (30\% lipase) e Hex 12 (15\% de lipase) foram preparados utilizando água como não-solvente (Figura 57c). As condições foram selecionadas a partir dos resultados obtidos na preparação de esferas sem a presença de enzimas (seção 4.4.1). 
Figura 57. Fotografias de (a) mat de Hex 6 (11\%) e $100 \mathrm{mg}$ de lipase (30\%) nas condições: $10 \mathrm{~cm}$ de distância, $25 \mathrm{kV}$ de tensão e fluxo de 15,5 $\mu \mathrm{L} \cdot \mathrm{min}^{-1}$; (b) esferas de Hex 12 (15\% de lipase) em metanol; (c) esferas de Benz 12 (15\% de lipase) em água.
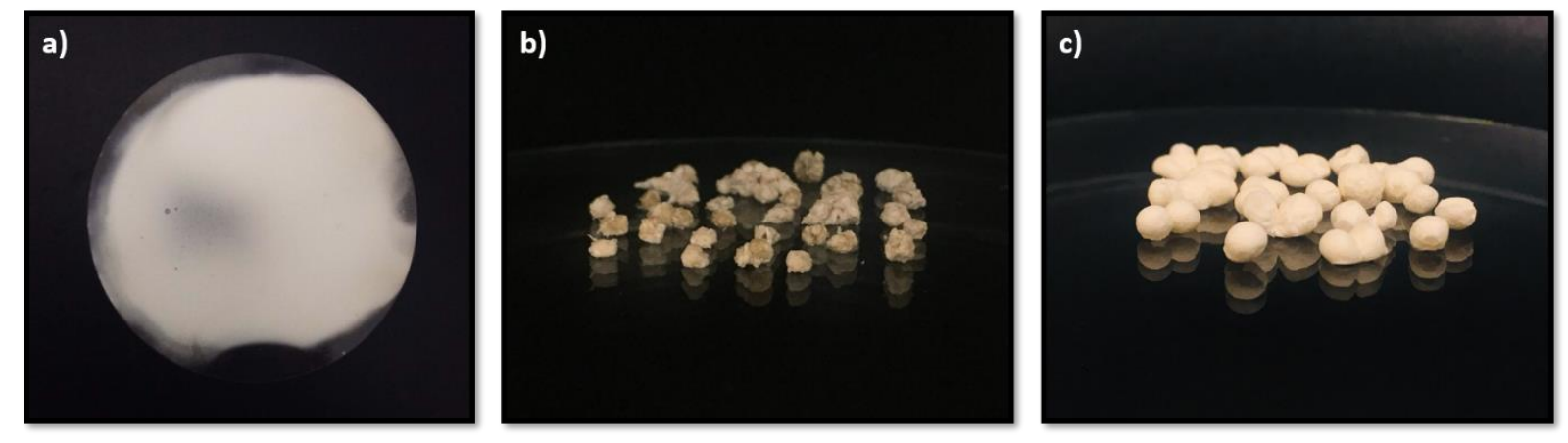

Observou-se que as esferas obtidas utilizando metanol como não-solvente apresentaram formato esférico não uniforme e superfícies rugosas. Isto pode ser atribuído à contração das partículas durante a secagem das esferas. As esferas obtidas utilizando água como não-solvente apresentaram formato esférico e uniformem e superfícies pouco rugosas.

A Figura 58a apresenta a micrografia da superfície de um mat de Hex 6 (11\%), obtido usando como condição de eletrofiação $10 \mathrm{~cm}$ de distância entre agulha e coletor, tensão de 25 $\mathrm{kV}$ e fluxo de 15,5 $\mu \mathrm{m} \cdot \mathrm{min}^{-1}$ sem a presença de lipase. Observou-se formação de fibras com diâmetro médio de $117 \mathrm{~nm}$ e presença de beads na estrutura. Adicionando 1,5\% de lipase e utilizando as mesmas condições de eletrofiação (Figura 58b), observou-se a formação de beads rugosos. Aumentando a concentração de enzima na solução eletrofiada (3\% de lipase) (Figura 58c), observou-se o início de formação de fibras, mas predominância de beads. Utilizando 5\% de lipase (Figura 58d), observou-se a formação de um material filmogêneo e poroso com beads na estrutura. 
Figura 58. Micrografias de Hex $6(11 \%)$ com $10 \mathrm{~cm}$ de distância, tensão de $25 \mathrm{kV}$ e $15,5 \mu$ m.min ${ }^{-1}$ nas seguintes condições: (a) Hex 6 (11\%); (b) Hex 6 (11\%) com Lipase (1,5\%); (c) Hex 6 (11\%) Lipase (3\%);

(d) Hex $6(11 \%)$ com Lipase $(5 \%)$.
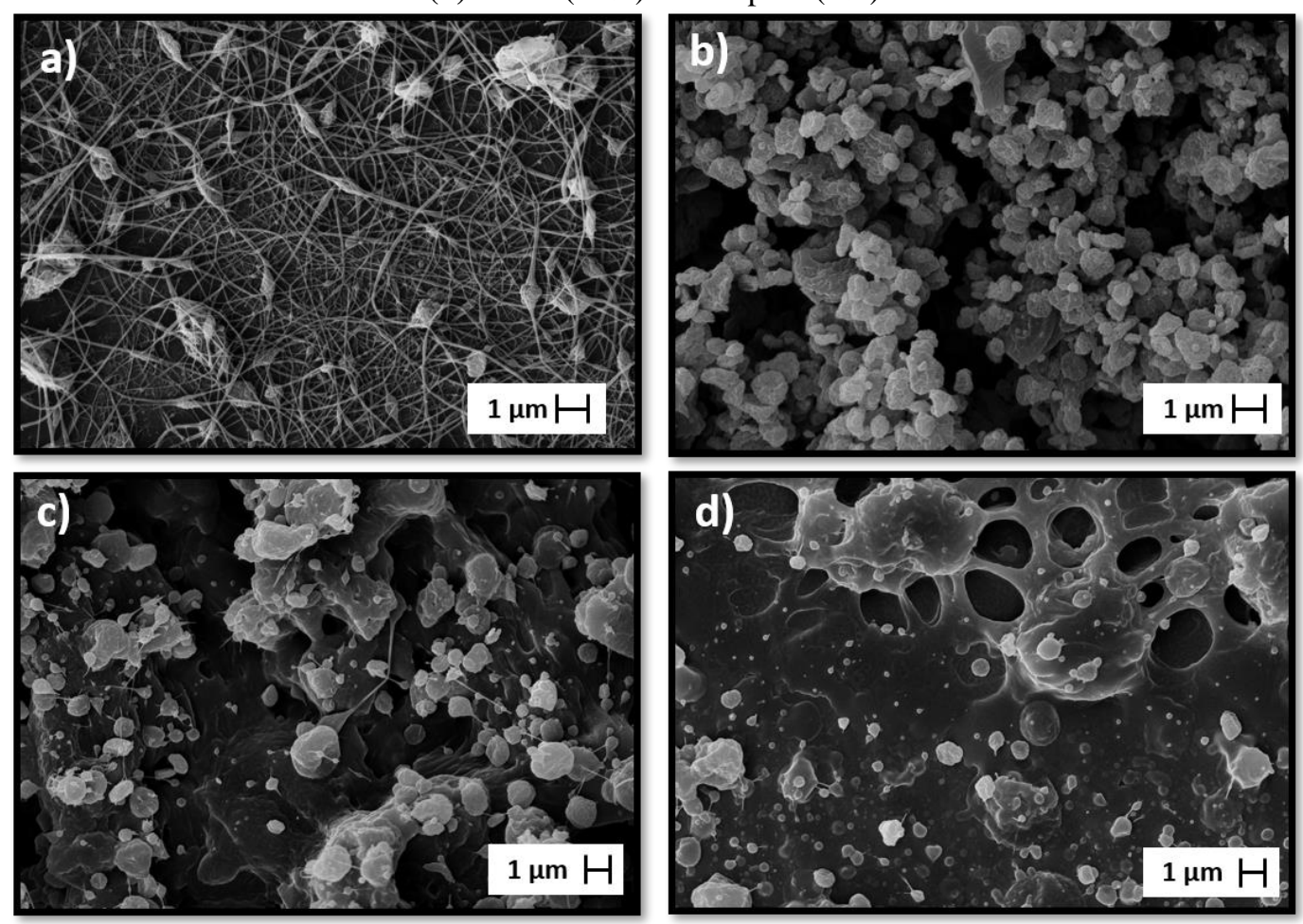

A Figura 59a mostra micrografias de esferas de Benz 12 obtidas usando água como não-solvente, as quais apresentaram formato esférico não uniforme com superfície pouco rugosa e diâmetro médio de 3,4 mm. A Figura 59b mostra imagens das esferas de Benz 12 utilizando metanol como não-solvente. Verificou-se que o diâmetro médio foi de $3,1 \mathrm{~mm}$ e a rugosidade foi mais elevada comparada à esfera preparada em água. O mesmo pode ser verificado para esferas de Hex 6 contendo 15\% de lipase em água (Figura 59c). A esfera apresentou formato esférico não uniforme, a superfície aparentou pouca rugosidade e o diâmetro médio foi 3,3 mm. Esferas de Hex 6 contendo 15\% de lipase em metanol (Figura 59d) apresentaram maior rugosidade e diâmetro médio de $2,8 \mathrm{~mm}$. 
Figura 59. Micrografias de esferas de e respectiva micrografia da rugosidade de Benz 12 com $15 \%$ de lipase em (a) água e (b) metanol; Hex 6 com 15\% de lipase em (c) água e (d) metanol.
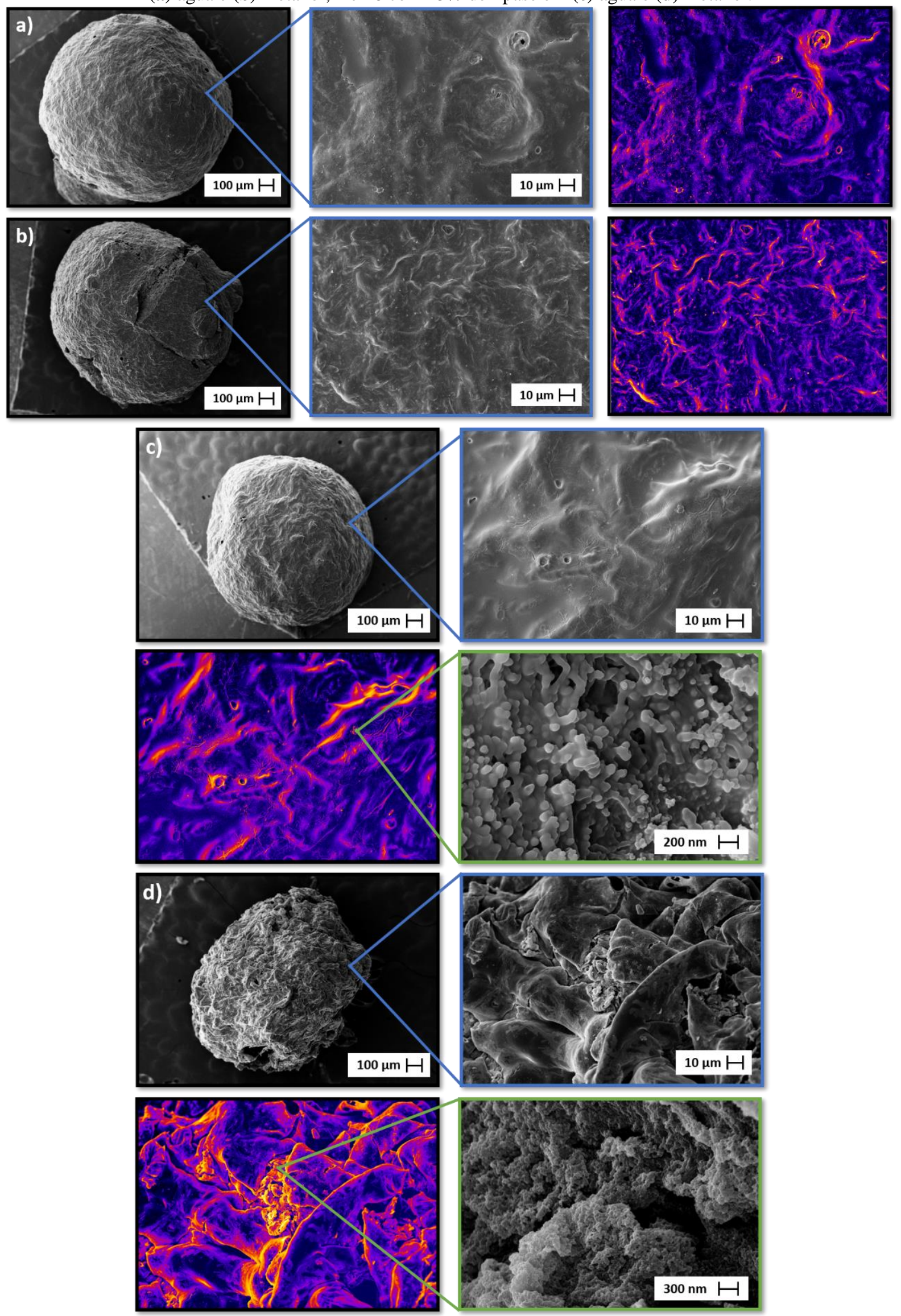
De modo geral, esferas de ésteres de celulose e lipase (15 e 30\%) preparadas utilizando metanol como não-solvente (Hex 6 e Hex 12) diminuíram de tamanho durante o processo de secagem, havendo assim uma redução no diâmetro das esferas, indicando que o interior das esferas estava intumescido por moléculas de água. As esferas de ésteres de celulose preparados com lipase utilizando água como não-solvente, apresentaram diâmetros maiores visto que não sofreram encolhimento no processo de secagem. Micrografias semelhantes foram obtidas para: Hex 6 (10\% LPF) em metanol; Hex 6 (15\% LPF) em água; Benz 6 (15\% LPF) em metanol; Benz 12 (15\% LPF) em metanol; Benz 12 (15\% LPF) água; Hex 6 (10\% LPF) em água. Não foram preparadas até o momento esferas a partir de ésteres mistos.

\subsection{Aplicação na Resolução Cinética de Cloridrina Racêmica}

A Figura 60 apresenta os cromatogramas obtidos por CG-DIC da cloridrina racêmica (R,S-2-cloro-1-feniletan-1-ol), e do seu respectivo derivado padrão acetato racêmico utilizando uma coluna quiral de $\beta$-ciclodextrina.

Figura 60. Cromatogramas obtidos por GC-DIC para a cloridrina racêmica e do padrão de acetato racêmico.

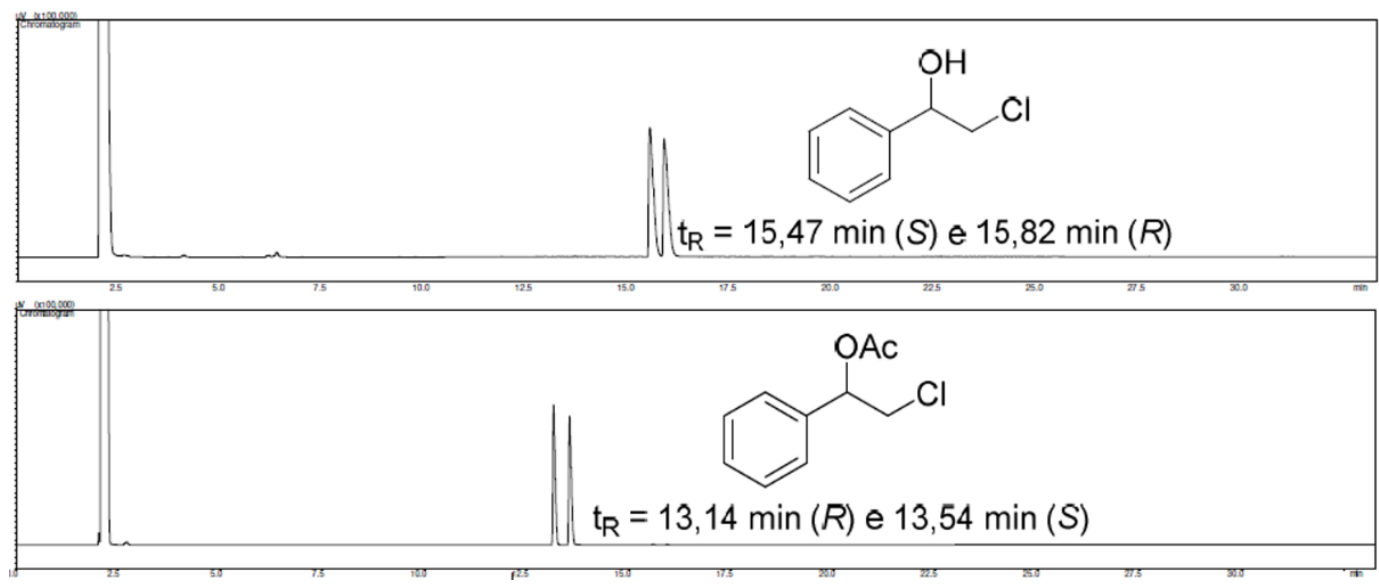

Fonte: FERREIRA, 2016.

Foram observados tempos de retenção distintos dos pares enantioméricos tanto do padrão racêmico da cloridrina, quanto do seu derivado racêmico acetilado, o que permitiu que esses cromatogramas fossem utilizados como referências para os estudos preliminares de resolução cinética enzimática envolvendo essa cloridrina.

$\mathrm{Na}$ resolução cinética enzimática da cloridrina racêmica foram adicionados no meio reacional cloridrina racêmica (R,S-2-cloro-1-feniletan-1-ol), acetato de vinila, hexano e lipase imobilizada em mantas de Hex 6 (15 e 30\% de lipase) com $10 \mathrm{~cm}$ de distância, tensão de $25 \mathrm{kV}$ 
e 15,5 $\mu \mathrm{m} \cdot \mathrm{min}^{-1}$ e esferas de Hex 6 (30\% de lipase), Hex 6 (15\% de lipase) e Hex 12 (15\% de lipase) em metanol e, esferas de Hex 6 (30\% lipase) e Hex 12 (15\% de lipase) em água (Figura 24).

As condições de reação foram a $32^{\circ} \mathrm{C}, 130 \mathrm{rpm}, 48 \mathrm{~h}$. A cada $24 \mathrm{~h}$ coletou-se uma alíquota do meio reacional, as quais foram analisadas por Cromatógrafo a Gás acoplado a um detector de ionização de chama (CG-DIC) para a determinação dos seguintes parâmetros das reações: percentual de conversão dos reagentes em produtos $(\boldsymbol{\%} \boldsymbol{c})$, razão enantiomérica $(\boldsymbol{E})$, excesso enantionérico (ee). Os compostos álcool (R-2-cloro-1-feniletan-1-ol) e acetato (Sacetato de 2-cloro-1-feniletan-1-ol) enantiomericamente puros foram obtidos por meio de reação de transesterificação.

A Figura 61 apresenta os cromatogramas de separação dos enantiômeros das cloridrinas racêmicas após $120 \mathrm{~h}$ de reação. Por meio de análises cromatográficas foi possível acompanhar o comportamento das reações na presença de enzimas, possibilitando analisar a seletividade das mesmas.

A Tabela 15 apresenta os resultados dos estudos de resolução cinética enzimática das cloridrinas racêmicas. A primeira aplicação é a utilização da enzima na sua forma pura e isolada no meio reacional. A segunda aplicação é na sua forma imobilizada em esferas de ésteres de celulose, que consiste no confinamento físico da enzima em um suporte. Para Esferas de Hex 12 (15\% LPF) água, após a primeira aplicação (Ciclo 1), as esferas foram recuperadas por filtração simples, lavada com hexano, e aplicadas novamente (Ciclo 2). 
Figura 61. Cromatogramas obtidos por CG-DIC da resolução cinética enzimática de cloridrina (R,S 2-cloro-1-feniletan-1-ol) utilizando lipase imobilizada em esferas de éster de celulose, com indicação do contra-solvente usado: (a) Hex 6 (30\% LPF) água; (b) Hex 6 (30\% LPF) metanol;

(c) Hex 6 (15\% LPF) metanol; (d) Hex 12 (15\% LPF) metanol; (e) Hex 12 (15\% LPF) água.
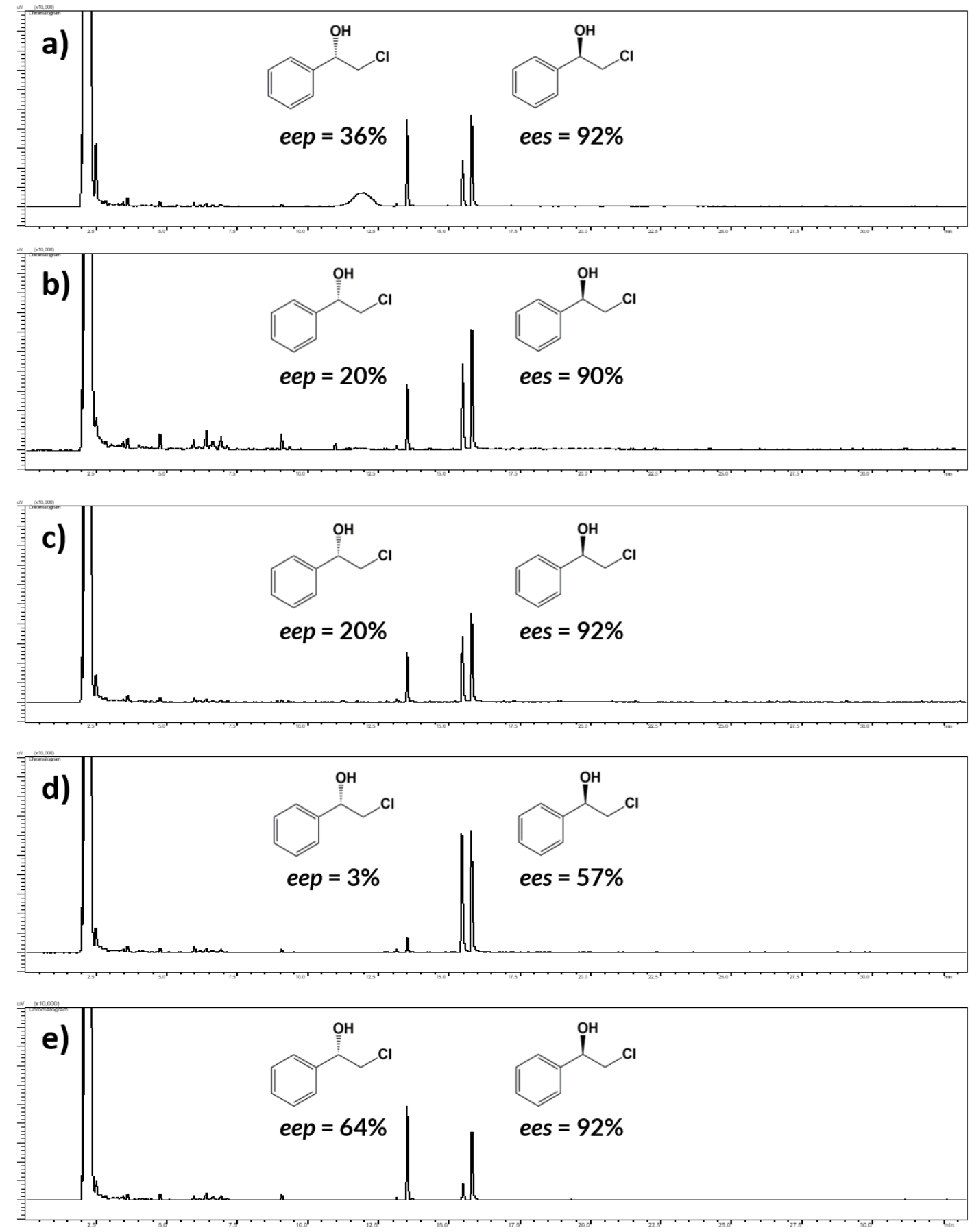

* excesso enantiomérico de substrato $\left(\boldsymbol{e} \boldsymbol{e}_{\boldsymbol{s}}\right)$ e excesso enantiomérico de produto $\left(\boldsymbol{e} \boldsymbol{e}_{\mathrm{p}}\right)$ 
Observou-se que a lipase referência de Pseudomonas fluorescens apresentou conversão moderada $(c=34 \%)$, excelente pureza enantiomérica $\left(e e_{p}=98 \%\right)$ para o acetato $(\mathrm{S})$ 2-cloro-1-feniletan-1-ol em 48h de reação e excelente razão enantiomérica $(E=212)$ (Tabela 15). O parâmetro $E$ (razão enantiomérica) traduz em termos numéricos a seletividade enzimática, descrevendo a relação entre a conversão e os excessos enantioméricos do substrato $\left(e e_{s}\right)$ e do produto $\left(e e_{p}\right)$. Um valor elevado de $E$ assegura não apenas um excesso enantiomérico elevado, mas também um rendimento proporcionalmente alto. Um valor de $E$ abaixo de 10 para qualquer biotransformação torna-a inviável como um processo enantiosseletivo. Por outro lado, este pode ser considerado bom se estiver situado entre aproximadamente 10 e 30 e, acima disto, excelente (COSTA; AMORIM, 1999).

Os resultados dos parâmetros enantioméricos apresentados na Tabela 15 foram melhores empregando as enzimas na forma livre. Comparando as conversões (\%c) das resoluções enzimáticas da cloridrina em produtos, observou-se que a lipase na forma livre apresentou maiores taxas de conversão $(c=34 \%)$ em relação às resoluções enzimáticas utilizando a lipase na forma imobilizada; exceto para o primeiro ciclo da amostra Hex 12 (15\% LPF) em água que apresentou conversão superior após $120 \mathrm{~h}$ de reação $(c=40 \%)$ e boa razão enantiomérica $(E=66)$. Em relação à pureza enantiomérica do produto, verificou-se que ambos foram elevados sendo 98\% para a lipase livre e 94\% para a lipase imobilizada (Tabela 15).

Após a resolução cinética da cloridrina racêmica, a amostra de Hex 12 (15\% LPF) em água, como mencionado, foi recuperada por filtração simples, lavada com hexano e reutilizada em um segundo ciclo de reação. Reutilizando as esferas imobilizadas com lipase em um segundo ciclo de reação, observou-se que houve uma redução da taxa de conversão de $40 \%$ para $16 \%$. A pureza enantiomérica do produto também diminuiu de 94 para $85 \%$ e excesso enantiomérica do substrato foi de 66 para 14\% (Tabela 15). Apesar da baixa porcentagem de conversão, o processo ainda pode ser considerado como viável, visto que $10<\mathrm{E}<30$, além de corresponder ao reuso da enzima imobilizada. 
Tabela 15. Resolução cinética de cloridrina (R,S 2-cloro-1-feniletan-1-ol) utilizando lipase imobilizada em esferas de éster de celulose com valores de excesso enantiomérico de substrato $\left(e e_{s}\right)$, excesso enantiomérico de produto $\left(e e_{\mathbf{p}}\right)$, conversão $(c)$ e razão enantiomérica $(E)$, sendo indicado o não-solvente usado na formação das esferas (água ou metanol).

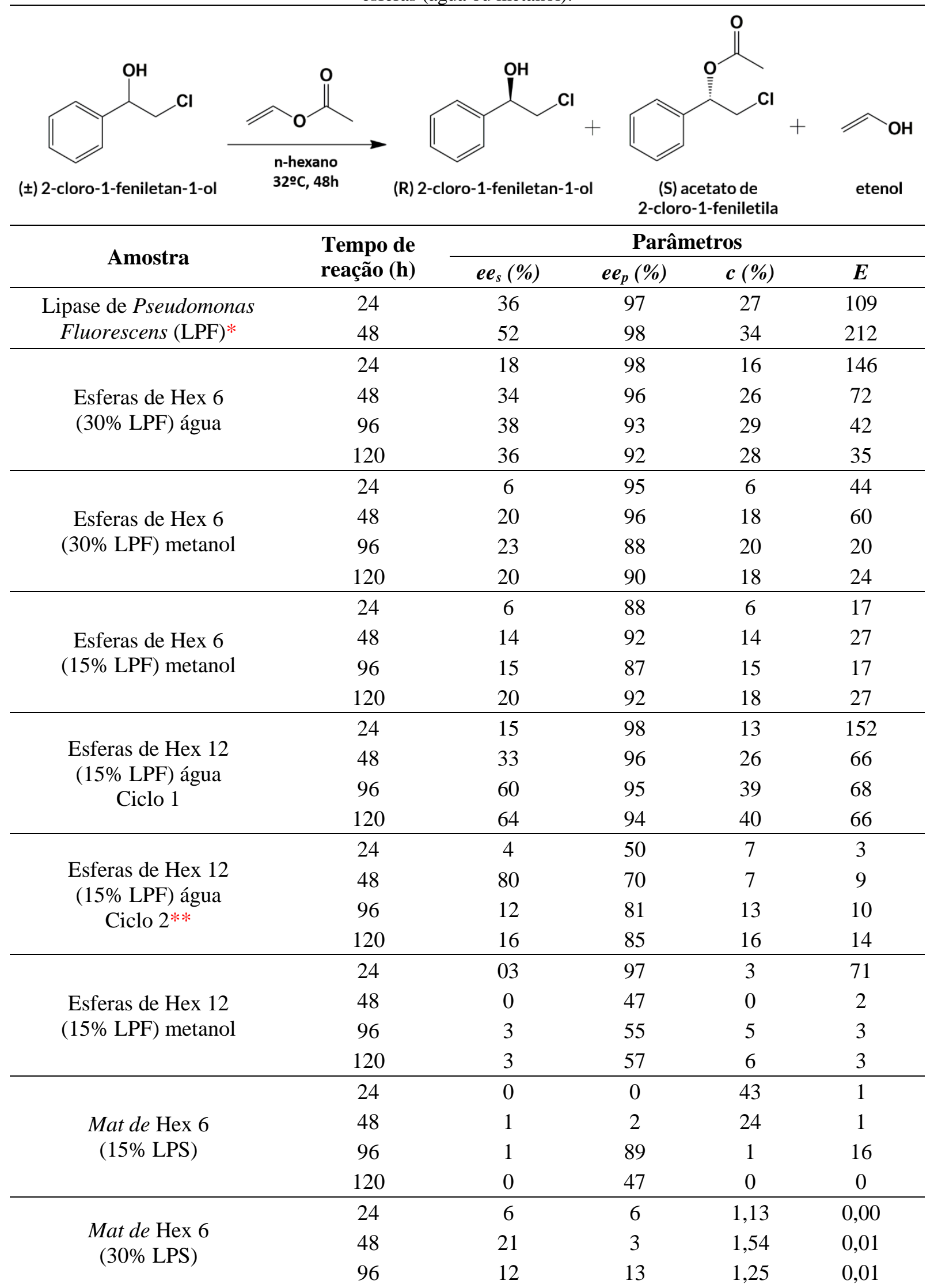




\begin{tabular}{cccccc} 
& 120 & 99 & 2 & 2 & 0,02 \\
\hline Fibroína & 24 & 11 & 99 & 10 & $>200$ \\
$(100 \mathrm{mg} \mathrm{LPF})^{*}$ & 48 & 34 & 99 & 26 & $>200$ \\
\hline
\end{tabular}

*Fonte: FERREIRA, 2016; FERREIRA et al., 2017.

**Reuso de Esferas de Hex 12 (15\% LPF) água.

A reação utilizando esferas de Hex 6 (30\% de lipase) em metanol apresentou 18\% de conversão após $120 \mathrm{~h}$, uma boa razão de conversão $(\mathrm{E}=24)$, excesso enantiomérico de produto 90\% e excesso enantiomérico de substrato de $20 \%$ (Tabela 15), justificado em função da baixa taxa de conversão.

Os resultados evidenciaram a influência das condições de preparo das lipases imobilizadas e do tipo de suporte utilizados, na atividade das enzimas. Comparando amostras de Hex 6 (30\% LPF) em água e Hex 6 (30\% LPF) em metanol, verificou-se redução do valor da conversão no produto acetilado de $c=28 \%$ para $c=18 \%$, assim como pureza enantiomérica do produto que diminuiu de $e e_{p}=92 \%$ para $e e_{p}=90 \%$ e a pureza enantiomérica do substrato que diminuiu de $e e_{s}=36 \%$ para $e e_{s}=20 \%$. A razão enantiomérica foi boa para ambas as reações sendo 35 e 24, respectivamente (Tabela 15). Este fato pode ser atribuído à porosidade e tamanho das esferas. Esferas preparadas utilizando metanol como não-solvente apresentaram contração durante o processo de secagem, havendo assim uma redução diâmetro das mesmas. Este diâmetro reduzido dificultou o intumescimento da esfera impedindo que o substrato alcançasse a lipase e seu sítio ativo, o que consequentemente abalou a eficiência catalítica. Além disso, como o processo de interação enzima-suporte é aleatório, a região do sítio ativo pode ter se tornado menos acessível ao substrato (impedimento estérico), o que acarretou, também, uma redução na atividade. As esferas preparadas utilizando água como não-solvente, apresentaram diâmetros maiores visto que não sofreram encolhimento na secagem. O diâmetro maior faz com que a esfera tenha mais poros, tornando o intumescimento facilitado e assim, tornando livre o acesso do substrato ao sítio ativo da lipase.

$\mathrm{Na}$ resolução cinética enzimática utilizando uma quantidade menor de lipase de Pseudomonas fluorescens (15\% FPF) em Hex 6 em metanol, também foi averiguada baixa conversão em produto $(c=18 \%)$. Na resolução cinética enzimática de amostras de Hex $12(15 \%$ LPF), não foi observada reação visto que a taxa de conversão enantiomérica foi reduzida $(c=$ $6 \%)$ e uma razão enantiomérica baixa $(\mathrm{E}<10)$ torna a reação inviável.

Em se tratando dos estudos de resolução cinética utilizando as enzimas imobilizadas por encapsulamento em fibroína, as resoluções foram menos eficientes ( $c=34 \%$ ) comparadas com as reações utilizando enzima na sua forma livre não imobilizada (FERREIRA et al., 2017). 
A conversão utilizando Hex 12 (15\% LPF) em água apresentou melhor resultado após 120h de reação $(c=40 \%)$ (Tabela 15$)$.

Outras resoluções cinéticas enzimáticas foram realizadas com as seguintes esferas: Hex 6 (10\% LPF) em metanol; Hex 6 (15\% LPF) em água; Benz 6 (15\% LPF) em metanol; Benz 12 (15\% LPF) em metanol; Benz 12 (15\% LPF) água; Hex 6 (10\% LPF) em água, porém não foi observada reação visto que os valores de $E$ obtidos foram abaixo de 10, (resultados não mostrados), o que torna qualquer biotransformação inviável.

Na resolução cinética enzimática de mats de Hez 6 com 30\% de LPF, as mantas foram utilizadas sobre o suporte de vidro em que foram coletas na eletrofiação (Figura 57a) e, portanto, apenas uma superfície estava exposta ao meio reacional. Através da reação verificouse que a opção de uso do mat sobre o suporte de vidro, visando manter a integridade do material, foi equivocada. Isto foi comprovado pelos resultados obtidos de taxa de conversão de $2 \%$ e de pureza enantiomérica do produto $99 \%$. O mesmo pode ser considerado para mat de Hex 6 com $15 \%$ de LPF. Para ambos foi observada uma razão enantiomérica baixa $(\mathrm{E}<10)$ o que indica uma reação inviável. Adicionalmente, essas mantas foram preparadas utilizando as seguintes condições de eletrofiação: distância de $10 \mathrm{~cm}$, tensão de $25 \mathrm{kV}$ e fluxo de injeção de 15,5 $\mu \mathrm{m} \cdot \mathrm{min}^{-1}$. A elevada tensão aplicada poderia influenciar significativamente a atividade da enzima podendo inativar parcial ou completamente as enzimas, causando mudanças estruturais e conformacionais (POOJARY et al., 2017).

O campo elétrico pulsado (CEP) é um método de conservação de alimentos em substituição à pasteurização, utilizado para eliminação de micro-organismos e na inativação de enzimas. Ho, Mittal e Cross reportaram o efeito do tratamento com CEP na lipase dispersa em água destilada observando cerca de $90 \%$ de inativação da lipase aplicando o processamento do CEP nas seguintes condições: voltagem de $88 \mathrm{kV} / \mathrm{cm}$; largura de pulso de $2 \mu \mathrm{s}$; duração do tratamento $2 \mathrm{~s}$; frequência $0,5 \mathrm{~Hz}$; número de pulsos 30 ; e temperatura máxima empregada $20^{\circ} \mathrm{C}$ (HO; MITTAL; CROSS, 1997). Em outro estudo, foi observado 62\% de inativação de lipase em processo em batelada e $13 \%$ em processo de fluxo contínuo de leite simulado ultrafiltrado tratado com CEP sob as seguintes condições: voltagem 27,4-37,3 kV/cm; largura de pulso $4 \mu \mathrm{s}$; duração do tratamento $314,5 \mu$ s; número de pulsos 80-100; e temperatura máxima empregada $34^{\circ} \mathrm{C}$ (BENDICHO et al., 2002). Os diferentes graus de inativação da lipase observados podem ser devidos a diferentes condições de processamento e meio utilizados.

A utilização da eletrofiação para produção de enzimas imobilizadas em mantas vem sendo estudada. Aldhahri et al. Reportou que enzima $\alpha$-amilase e substrato Alq3 foram eletrofiados juntamente com o polímero de carbotano em etanol por meio da técnica de co- 
electrosppining utilizando as seguintes condições: $19,5 \mathrm{kV}$ de tensão, $15 \mathrm{~cm}$ de distância e fluxo de $0,9 \mathrm{~mL} \cdot \mathrm{h}^{-1}$ (ALDHAHRI et al., 2018). Após 10 ciclos a enzima apresentou $30 \%$ da atividade inicial.

Wang e Hsieh também reportaram imobilização de enzimas em mantas por coelectrosppining. Polivinil álcool (PVA) e lipase de Candida rugosa foram eletrofiados na seguinte configuração experimental: $10 \mathrm{kV}$ de tensão e $17,78 \mathrm{~cm}$ de distância sendo a atividade catalítica da enzima imobilizada igual à enzima bruta não mostrando efeitos adversos das cargas elétricas na estrutura ou nas funções das proteínas da enzima. (WANG; HSIEH, 2008).

A partir do exposto, faz-se necessária uma investigação mais aprofundada para examinar a influência da voltagem na atividade enzimática nas condições de eletrofiação, tendo em vista os relatos de sucesso usando voltagens inferiores à usada no presente estudo (WANG; HSIEH, 2008; ALDHAHRI et al., 2018), assim como aplicação do mat contendo a enzima livre de suporte, para aumentar a superfície exposta ao substrato. 


\section{CONCLUSÕES}

Ésteres de celulose de linter foram sintetizados com diferentes grupos substituintes Em relação aos benzoatos de celulose e ésteres mistos hexanoato-benzoato de celulose, a derivatização foi comprovada pelos espectros na região do infravermelho, mas o grau médio de substituição calculado pelo espectro de $\mathrm{RNM} \mathrm{H}^{1}$ não foi compatível com a intensidade das bandas referentes aos grupos carbonila observadas nos espectros na região do infravermelho

A avaliação dos mats obtidos por eletrofiação comprovou a formação de fibras ultrafinas com diâmetros médios de $150 \mathrm{~nm}$, bem como a comprovação do uso de menor fluxo de injeção favorecendo formação de fibras ultrafinas. Ainda será necessário explorar condições que possam favorecer a formação de nanofibras, e minimizar os defeitos (beads).

Esferas foram preparadas por meio de gotejamento em não-solvente, sendo que as preparadas utilizando metanol como não-solvente apresentaram diâmetros menores e rugosidade maior, comparadas àquelas obtidas utilizando água como não-solvente.

Lipases de Pseudomonas fluorescens foram imobilizadas em esferas Hex 6 (15 e 30\% de LPF) em água e metanol, Hex 12 (15\% de LPF) em água por encapsulamento e aplicadas na resolução cinética enzimática de cloridrinas racêmicas. A lipase referência, não imobilizada, apresentou conversão moderada $(c=34 \%)$, excelente pureza enantiomérica $\left(e e_{p}=98 \%\right)$ e excelente razão enantiomérica $(E=212)$. Para lipases imobilizadas em esferas de Hex $12(15 \%$ LPF), obtidas usando água como não-solvente, os resultados se mostraram promissores, a conversão foi superior após $120 \mathrm{~h}$ de reação $(\mathrm{c}=40 \%)$, e a pureza enantiomérica do produto foi 94\%. A lipase imobilizada em mantas de Hex 6 com concentrações de 15 e $30 \%$ não apresentou atividade catalítica sendo necessária uma melhor investigação a fim de verificar a influência da voltagem na atividade enzimática nas condições de eletrofiação.

O presente estudo levou a um conjunto de resultados que pode embasar futuras investigações sobre sínteses de benzoatos de celulose e de ésteres mistos hexanoato- benzoato, assim como sobre obtenção de mantas via eletrofiação e de esferas a partir dos ésteres sintetizados. Destaca-se ainda que os resultados obtidos na resolução cinética enzimática de cloridrinas racêmicas podem contribuir com estudos envolvendo resoluções de outras misturas racêmicas. 


\section{REFERÊNCIAS BIBLIOGRÁFICAS}

ABIDI, N.; CABRALES, L.; HAIGLER, C. H. Changes in the cell wall and cellulose content of developing cotton fibers investigated by FTIR spectroscopy. Carbohydrate Polymers, Oxford, v. 100, p. 9-16, 2014.

ADLERCREUTZ, P. Immobilisation of lipases in organic media. Chemical Society Reviews, Cambridge, v. 42, n. 15, p. 6406-6436, 2013.

AGARWAL, S.; WENDORFF, J. H.; GREINER, A. Use of electrospinning technique for biomedical applications. Polymer, London, v. 49, n. 26, p. 5603-5621, 2008.

AHVENAINEN, P.; KONTRO, I.; SVEDSTRÖM, K. Comparison of sample crystallinity determination methods by X-ray diffraction for challenging cellulose I materials. Cellulose, Dordrecht, v. 23, n. 2, p. 1073-1086, 2016.

ALDHAHRI, M. M.; ALMULAIKY, Y. Q.; EL-SHISHTAWY, R. M.; ALNGADH, A.; MAGHRABI, R. Facile immobilization of enzyme via Co-electrospinning: a simple method for enhancing enzyme reusability and monitoring an activity-based organic semiconductor. ACS Omega, Oxford, v. 3, n. 6, p. 6346-6350, 2018.

ALMEIDA, É. V. R. Valorização da celulose de sisal: uso na preparação de acetatos e de filmes de acetatos de celulose/celulose e quitosana/celulose. 2009. Tese (Doutorado em Química) - Instituto de Química de São Carlos, Universidade de São Paulo, São Carlos, 2009.

ALMEIDA, E. V. R.; MORGADO, D. L.; RAMOS, L. A.; FROLLINI, E. Sisal cellulose and its acetates: generation of films and reinforcement in a one-pot process. Cellulose, Dordrecht, v. 20, n. 1 , p. $453-465,2013$.

AMERICAN SOCIETY FOR TESTING AND MATERIALS. ASTM D1795-13 standard test method for intrinsic viscosity of cellulose. West Conshohocken, 2013.

ARMAREGO, W. L. F.; CHAI, C. L. L. Purification of laboratory chemicals. 6. ed. New York: Elsevier, 2009.

ASAHI KASEI CORPORATION. What is BEMCOT. Tokyo, 2019. Disponível em: https://www.asahi-kasei.co.jp/bemliese/en/bemcot/what-bemcot/index.html. Acesso em: 3 jan. 2019.

ASS, B. A. P.; BELGAGEM, M. N.; FROLLINI, E. Mercerized linters cellulose: characterization and acetylation in N,N-dimethylacetamide/lithium chloride. Carbohydrate Polymers, Oxford, v. 63, n. 1, p. 19-29, 2006.

ASS, B. A. P.; CIACCO, G. T.; FROLLINI, E. Cellulose acetates from linters and sisal: correlation between synthesis conditions in $\mathrm{DMAc} / \mathrm{LiCl}$ and product properties. Bioresource Technology, Amsterdam, v. 97, n. 14, p. 1696-1702, 2006. 
ASS, B. A. P.; FROLLINI, E.; HEINZE, T. Studies on the homogeneous acetylation of cellulose in the novel solvent dimethyl sulfoxide/tetrabutylammonium fluoride trihydrate. Macromolecular Bioscience, Weinheim, v. 4, n. 11, p. 1008-1013, 2004.

AZIZI SAMIR, M. A. S.; ALLOIN, F.; DUFRESNE, A. Review of recent research into cellulosic whiskers, their properties and their application in nanocomposite field.

Biomacromolecules, Washington, v. 6, n. 2, p. 612-626, 2005.

BARTHLOTT, W.; ALLEE, M.; BONN, D.-; NEINHUIS, C.; WALZEL, P. Wetting and self-cleaning properties of artificial superhydrophobic surfaces. Langmuir, Washington, v. 21, p. 956-961, 2005.

BARUD, H. S.; DE ARAÚJO JÚNIOR, A. M.; SANTOS, D. B.; DE ASSUNÇÃO, R. M. N.; MEIRELES, C. S.; CERQUEIRA, D. A.; RODRIGUES FILHO, G.; RIBEIRO, C. A.; MESSADDEQ, Y.; RIBEIRO, S. J. L. Thermal behavior of cellulose acetate produced from homogeneous acetylation of bacterial cellulose. Thermochimica Acta, Amsterdam, v. 471, n. $1-2$, p. 61-69, 2008.

BAXTER, L. L.; MILES, T. R.; MILES, T. R.; JENKINS, B. M.; MILNE, T.; DAYTON, D.; BRYERS, R. W.; ODEN, L. L. The behavior of inorganic material in biomass-fired power boilers: field and laboratory experiences. Fuel Processing Technology, Amsterdam, v. 54, p. 47-78, 1998.

BENDICHO, S.; ESTELA, C.; GINER, J.; BARBOSA-CÁNOVAS, G. V.; MARTI, O. Effects of high intensity pulsed electric field and thermal treatments on a lipase from pseudomonas fluorescens. Journal of Dairy Science, New York, v. 85, p. 19-27, 2002.

BERG, J. M.; TYMOCZKO, J. L.; GATTO JUNIOR, G. J.; STRYER, L. Biochemistry. 8. ed. New York: W. H. Freeman \& Company, 2015.

BERGENSTRÅHLE, M.; WOHLERT, J.; HIMMEL, M. E.; BRADY, J. W. Simulation studies of the insolubility of cellulose. Carbohydrate Research, Oxford, v. 345, p. 20602066, 2010.

BERRY, J. D.; NEESON, M. J.; DAGASTINE, R. R.; CHAN, D. Y. C.; TABOR, R. F. Measurement of surface and interfacial tension using pendant drop tensiometry. Journal of Colloid and Interface Science, Maryland Heights, v. 454, p. 226-237, 2015.

BHARDWAJ, K. K.; GUPTA, R. Synthesis of chirally pure enantiomers by lipase. Journal of Oleo Science, Tokyo, v. 10, p. 1073-1084, 2017.

BHATIA, S. K.; GURAV, R.; CHOI, T.-R.; JUNG, H.-R.; YANG, S.-Y.; MOON, Y.-M.; SONG, H.-S.; JEON, J.-M.; CHOI, K.-Y.; YANG, Y.-H. Bioconversion of plant biomass hydrolysate into bioplastic (polyhydroxyalkanoates) using Ralstonia eutropha 5119.

Bioresource Technology, Amsterdam, v. 271, p. 306-315, 2019.

BILLMEYER JUNIOR, F. W. Textbook of Polymer Science. 3. ed. New York: John Wiley \& Sons, 1984. 
BLACHECHEN, L. S.; SOUZA, M. A.; PETRI, D. F. S. Effect of humidity and solvent vapor phase on cellulose esters films. Cellulose, Dordrecht, v. 19, p. 443-457, 2012.

BROWNING, B. L. Methods of wood chemistry. New York: Wiley, 1967.

BUSCHLE-DILLER, G.; ZERONIAN, S. H. Enhancing the reactivity and strength of cotton fibers. Journal of Applied Polymer Science, Hoboken, v. 45, n. 6, p. 967-979, 1992.

CARR, C. M. Chemistry of the textiles industry. Glasgow: Blackie Academic \& Professional, 1995.

CARVALHO, P. O.; CASS, Q. B.; CALAFATTI, S. A.; CONTESINI, F. J.; BIZACO, R. Review - alternatives for the separationof drug eneatiomers: ibuprofen as model compound. Brazilian Journal of Chemical Engineering, São Paulo, v. 23, n. 03, p. 291-300, 2006.

CHEN, C.; FUJIMOTO, Y.; GIRDAUKAS, G.; SIH, C. J. Quantitative analyses of kinetic resolutions of enantiomers. Journal of the American Chemical Society, Washington, v. 104, p. 1294-1299, 1982.

CHEN, Q.; YANG, R.; ZHAO, B.; LI, Y.; WANG, S.; WU, H.; ZHUO, Y.; CHEN, C. Investigation of heat of biomass pyrolysis and secondary reactions by simultaneous thermogravimetry and differential scanning calorimetry. Fuel, Oxford, v. 134, p. 467-476, 2014.

CHEN, Y.; JIANG, Y.; WAN, J.; WU, Q.; WEI, Z. Effects of wet-pressing induced fiber hornification on hydrogen bonds of cellulose and on properties of eucalyptus paper sheets. Holzforschung, Berlin, v. 72, n. 10, p. 1-9, 2018.

CHINGA, G. et al. Quantification of the 3D microstructure of SC surfaces. Journal of Microscopy, Chichester, v. 227, n. 3, p. 254-265, 2007.

CIACCO, G. T.; MORGADO, D. L.; FROLLINI, E.; POSSIDONIO, S.; EL SEOUD, O. A. Some aspects of acetylation of untreated and mercerized sisal cellulose. Journal of the Brazilian Chemical Society, São Paulo, v. 21, n. 1, p. 71-77, 2010.

CIACCO, G. T.; RAMOS, L. A.; FROLLINI, E.; ASS, B. A. P. Sisal, sugarcane bagasse and microcrystalline celluloses: influence of the composition of the solvent system N,NDimethylacetamide/lithium chloride on the solubility and acetylation of these polysaccharides. e-Polymers, Berlin, v. 8, n. 1, p. 1-11, 2008.

COLLINS, E. A.; BARES, J.; BILLMEYER JUNIOR, F. W. Experiments in polymer science. New York: Wiley-Interscience, 1973.

COSTA, R. G. F.; OLIVEIRA, J. E.; PAULA, G. F.; PICCIANI, P. H. S.; MEDEIROS, E. S.; RIBEIRO, C.; MATTOSO, L. H. C. Eletrofiação de polímeros em solução. Parte I: Fundamentação Teórica. Polímeros, São Carlos, v. 22, n. 2, p. 170-177, 2012.

COSTA, V. E. U.; AMORIM, H. L. N. O emprego de lipases como agentes de resolução cinética de enantiômeros em síntere orgânica: aspectos gerais sobre a influência do solvente.

Química Nova, São Paulo, v. 22, n. 6, p. 863-873, 1999. 
COULEMBIER, O.; JOSSE, T.; GUILLERM, B.; GERBAUX, P.; DUBOIS, P. An imidazole-based organocatalyst designed for bulk polymerization of lactide isomers: inspiration from Nature. Chemical Communications, Cambridge, v. 48, p. 11695-11697, 2012.

CULLITY, B. D.; STOCK, S. R. Elements of x-ray diffraction. 3. ed. London: Pearson, 2014.

CZEPAK, C.; FERNANDES, P. M.; ALBERNAZ, K. C.; RODRIGUES, O. D. Seletividade de inseticidas ao complexo de inimigos naturais do algodão (Gossypium hirsutum L.).

Pesquisa Agropecuária Tropical, Goiania, v. 35, n. 2, p. 123-127, 2005.

DAI, L.; CHENG, T.; DUAN, C.; ZHAO, W.; ZHANG, W.; ZOU, X.; ASPLER, J.; NI, Y. 3D printing using plant-derived cellulose and its derivatives: a review. Carbohydrate Polymers, Oxford, v. 203, p. 71-86, 2019.

DALLA-VECCHIA, R.; NASCIMENTO, M. G.; SOLDI, V. Aplicações sintéticas de lipases imobilizadas em polímeros. Química Nova, São Paulo, v. 27, n. 4, p. 623-630, 2004.

DAWSEY, T. R.; MCMORMICK, C. The lithium chloride/dimethylacetamide solvent for cellulose: a literature review. Journal of Macromolecular Science, Part C: Polymer Reviews, New York, v. 30, n. 3-4, p. 405-440, 1990.

DE OLIVEIRA SANTOS, R. P.; RAMOS, L. A.; FROLLINI, E. Cellulose and/or lignin in fiber-aligned electrospun PET mats: the influence on materials end-properties. Cellulose, Dordrecht, v. 26, n. 1, p. 617-630, 2019.

DEITZEL, J. M.; KLEINMEYER, J.; HARRIS, D.; TAN, N. C. B. The effect of processing variables on the morphology of electrospun nanofibers and textiles. Polymer, London, v. 42, p. 261-272, 2001.

DICOSIMO, R.; MCAULIFFE, J.; POULOSE, A. J.; BOHLMANN, G. Industrial use of immobilized enzymes. Chemical Society Reviews, Cambridge, v. 42, n. 15, p. 6437-6474, 2013.

DINAND, E.; VIGNON, M.; CHANZY, H.; HEUX, L. Mercerization of primary wall cellulose and its implication for the conversion of cellulose I $\rightarrow$ cellulose II. Cellulose, Dordrecht, v. 9, n. 1, p. 7-18, 2002.

DU, H.; LIU, W.; ZHANG, M.; SI, C.; ZHANG, X.; LI, B. Cellulose nanocrystals and cellulose nanofibrils based hydrogels for biomedical applications. Carbohydrate Polymers, Oxford, v. 209, p. 130-144, 2019.

DU, K.; YAN, M.; WANG, Q.; SONG, H. Preparation and characterization of novel macroporous cellulose beads regenerated from ionic liquid for fast chromatography. Journal of Chromatography A, Amsterdam, v. 1217, p. 1298-1304, 2010.

DURÁN, N.; ESPOSITO, E. Potential applications of oxidative enzymes and phenoloxidaselike compounds in wastewater and soil treatment: a review. Applied Catalysis B:

Environmental, Amsterdam, v. 28, p. 83-99, 2000. 
EL SEOUD, O. A.; FIDALE, L. C.; RUIZ, N.; D’ALMEIDA, M. L. O.; FROLLINI, E. Cellulose swelling by protic solvents: which properties of the biopolymer and the solvent matter? Cellulose, Dordrecht, v. 15, n. 3, p. 371-392, 2008.

EZATPOUR, H. R.; SAJJADI, S. A.; SABZEVAR, M. H.; HUANG, Y. Investigation of microstructure and mechanical properties of Al6061 - nanocomposite fabricated by stir casting. Materials \& Design, London, v. 55, p. 921-928, 2014.

FANG, D. D. Cotton fiber: physics, chemistry and biology. Cham: Springer International Publishing, 2018.

FENFEL, D.; WEGENER, G. Wood - chemistry, ultrastructure, reactions. 2. ed. Berlin: Walter de Gruyter, 1989.

FERRACINI, T. V. F. Materiais constituídos por fibras ultrafinas e nanofibras a partir da eletrofiação de soluções de acetato de celulose. 2017. Trabalho de Conclusão de Curso (Bacharelado em Química com Atribuições Tecnológicas) - Instituto de Química de São Carlos, Universidade de São Paulo, São Carlos, 2017.

FERREIRA, D. C. Ésteres mistos de celulose: síntese em meio homogêneo, caracterização e moldagem. 2018. Tese (Doutorado em Química) - Instituto de Química, Universidade de São Paulo, São Paulo, 2018.

FERREIRA, G. B.; CARVALHO, M. da C. S. Adubação do algodoeiro no cerrado: com resultados de pesquisa em Goiás e Bahia. Campina Grande: Embrapa Algodão, 2005.

FERREIRA, I. M. Imobilização do fungo Penicillium citrinum CBMAI 1186 e lipase de Pseudomonas fluorescens em biopolímeros para aplicações em biocatálise. 2016. Tese (Doutorado em Química) - Instituto de Química de São Carlos, Universidade de São Paulo, São Carlos, 2016.

FERREIRA, I. M.; YOSHIOKA, S. A.; COMASSETO, J. V.; PORTO, A. L. M. Immobilization of amano lipase from pseudomonas fluorescens on silk fibroin spheres: an alternative protocol for the enantioselective synthesis of halohydrins. RSC Advances, Cambridge, v. 7, p. 12650-12658, 2017.

FIDALE, L. C. Biopolímeros modificados: aspectos de derivatização de celulose sob condições homogêneas de reação. Tese (Doutorado em Química) - Instituto de Químcia, Universidade de São Paulo, São Paulo, 2010.

FINK, H. P.; WALENTA, E.; KUNZE, J.; MANN, G. Cellulose and cellulose derivatives: physico-chemical aspects and andustrial applications. Cambridge: Woodhead Publisher, 1995.

FLAQUÉ, C.; MONTSERRAT, S. Thermal degradation of celluloses and their vinylic copolymers by thermogravimetric analysis. Journal of Applied Polymer Science, Hoboken, v. 74, n. 1, p. 201-209, 1999. 
FONG, H.; CHUN, I.; RENEKER, D. H. Beaded nanofibers formed during electrospinning. Polymer, London, v. 40, p. 4585-4592, 1999.

FRENCH, A. D. Idealized powder diffraction patterns for cellulose polymorphs. Cellulose, Dordrecht, v. 21, n. 2, p. 885-896, 2014.

FRENCH, A. D.; SANTIAGO CINTRÓN, M. Cellulose polymorphy, crystallite size, and the Segal Crystallinity Index. Cellulose, Dordrecht, v. 20, n. 1, p. 583-588, 2013.

FU, J.; PANG, Z.; YANG, J.; HUANG, F.; CAI, Y.; WEI, Q. Applied Surface Science Fabrication of polyaniline/carboxymethyl cellulose/cellulose nanofibrous mats and their biosensing application. Applied Surface Science, Amsterdam, v. 349, p. 35-42, 2015.

FU, L.-H.; QI, C.; MA, M.-G.; WAN, P. Multifunctional cellulose-based hydrogels for biomedical applications. Journal of Materials Chemistry B, Cambridge, v. 7, n. 10, p. 1541-1562, 2019.

GABRIEL, L. P.; AMÉLIA, A.; MACEDO, M.; JARDINI, A. L.; MACIEL, R. Electrospun polyurethane membranes for tissue engineering applications. Materials Science \& Engineering C, Amsterdam, v. 72, p. 113-117, 2017.

GANDINI, A. The irruption of polymers from renewable resources on the scene of macromolecular science and technology. Green Chemistry, Cambridge, v. 13, n. 5, p. 10611083, 2011.

GARDINER, S.; SARKO, A. Packing analysis of carbohydrates and polysaccharides. 16 . The crystal structures of celluloses IV (I), and IV (II). Canadian Jounal of Chemistry, Ottawa, v. 63, n. 1, p. 173-180, 1985.

GERICKE, M.; TRYGG, J.; FARDIM, P. Functional cellulose beads: preparation, characterization, and applications. Chemical Reviews, Washington, v. 113, n. 7, p. 48124836, 2013.

GIBSON, L. J. The hierarchical structure and mechanics of plant materials. Journal of the Society Interface, London, p. 2749-2766, 2012.

GOMES, G. S.; ALMEIDA, A. T.; KOSAKA, P. M.; ROGERO, S.O.; CRUZ, A.S.; IKEDA, T.I.; PETRI, D.F.S. Cellulose acetate propionate coated titanium: characterization and biotechnological application. Materials Research, São Carlos, v. 10, n. 4, p. 469-474, 2007.

GOODLETT, V. W.; DOUGHERTY, J. T.; PATTON, H. W. Characterization of cellulose acetates by nuclear magnetic resonance. Journal of Polymer Science Part A-1: Polymer Chemistry, Hoboken, v. 9, n. 1, p. 155-161, 1971.

GORDON, S.; HSIEH, Y.-L. Cotton: science and technology. Cambridge: Woodhead Publishing in Textiles, 2007.

GREINER, A.; WENDORFF, J. H. Electrospinning: a fascinating method for the preparation of ultrathin fibers. Angewandte Chemie, Weinheim, v. 46, p. 5670-5703, 2007. 
GREISH, Y. E.; MEETANI, M. A.; AL MATROUSHI, E. A.; SHAMSI, B. Al. Effects of thermal and chemical treatments on the structural stability of cellulose acetate nanofibers. Carbohydrate Polymers, Oxford, v. 82, n. 3, p. 569-577, 2010.

GUMINA, B.; ESPRO, C.; GALVAGNO, S.; PIETROPAOLO, R.; MAURIELLO, F. Bioethanol production from unpretreated cellulose under neutral selfsustainable hydrolysis/hydrogenolysis conditions promoted by the heterogeneous $\mathrm{Pd} / \mathrm{Fe}_{3} \mathrm{O}_{4}$ catalyst. ACS Omega, Oxford, v. 4, n. 1, p. 352-357, 2019.

GUPTA, G. N.; SINGH, V. K.; PRAKASH, V. Molecular modeling and docking studies of cold active lipase from pseudomonas fluorescens. International Journal of Applied Biology and Pharmaceutical Technology, Houston, v. 6, n. 1, p. 59-66, 2015.

GUPTA, P. K.; UNIYAL, V.; NAITHANI, S. Polymorphic transformation of cellulose I to cellulose II by alkali pretreatment and urea as an additive. Carbohydrate Polymers, Oxford, v. 94, n. 2, p. 843-849, 2013.

HABIBI, Y.; LUCIA, L. A.; ROJAS, O. J. Cellulose nanocrystals: chemistry, self-assembly, and applications. Chemical Reviews, Washington, v. 110, n. 6, p. 3479-3500, 2010.

HEINZE, T.; EL SEOUD, O. A.; KOSCHELLA, A. Cellulose derivatives: synthesis, structure, and properties. Cham: Springer International Publishing, 2018.

HIROTA, M.; TAMURA, Æ. N. Surface carboxylation of porous regenerated cellulose beads by 4-acetamide-TEMPO/ $\mathrm{NaClO} / \mathrm{NaClO}_{2}$ system. Cellulose, Dordrecht, v. 16, p. 841-851, 2009.

HISHIKAWA, Y.; TOGAWA, E.; KONDO, T. Characterization of individual hydrogen bonds in crystalline regenerated cellulose using resolved polarized FTIR spectra. ACS Omega, Oxford, v. 2, n. 4, p. 1469-1476, 2017.

HO, S. Y.; MITTAL, G. S.; CROSS, J. D. Effects of high field electric pulses on the activity of selected enzymes. Journal of Food Engineering, London, v. 31, p. 69-84, 1997.

HOFFMANN, F.; CORNELIUS, M.; MORELL, J.; FRÖBA, M. Silica-based mesoporous organic - inorganic hybrid materials. Angewandte Chemie, Weinheim, v. 45, p. 3216-3251, 2006.

HOIK, D. P.; BIJUN, L.; YASUHITO, H.; KIM, M. I. Fabrication of electrospun chitosan/cellulose nanofibers having adsorption property with enhanced mechanical property. Cellulose, Dordrecht, v. 5, n. 3, p. 1781-1793, 2018.

HORII, F.; HIRAI, A.; KITAMARU, R. Solid-state 13C-NMR study of conformations of oligosaccharides and cellulose. Polymer Bulletin, Hoboken, v. 10, n. 7-8, p. 357-361, 1983.

HOSSAIN, K. M. Z.; PATEL, U.; AHMED, I. Development of microspheres for biomedical applications: a review. Progress in Biomaterials, Heidelberg, v. 4, p. 1-19, 2014.

HULT, E.; LARSSON, P. T.; IVERSEN, T. Cellulose fibril aggregation - an inherent property of kraft pulps. Polymer, London, v. 42, n. 8, p. 3309-3314, 2001. 
IME TECHNOLOGIES. Basic Set-up. Waalre, 2019. Disponível em: https://www.imeelectrospinning.com/electrospinning-machines/ec-dig/. Acesso em: 7 jan. 2019.

IUPAC. Compendium of chemical terminology. 2. ed. Oxford: Blackwell Sciene, 1997.

JAEGER, R.; SCHÖNHERR, H.; VANCSO, G. J. Chain packing in electrospun poly(ethylene oxide) visualized by atomic force microscopy. Macromolecules, Washington, v. 29, p. 7634-7636, 1996.

KASCHUK, J. J.; FROLLINI, E. Effects of average molar weight, crystallinity, and hemicelluloses content on the enzymatic hydrolysis of sisal pulp, filter paper, and microcrystalline cellulose. Industrial Crops and Products, Amsterdam, v. 115, p. 280-289, 2018.

KASCHUK, J. J.; LACERDA, T. M.; COMA, V.; FROLLINI, E. Enzymatic hydrolysis of mercerized and unmercerized sisal pulp. Cellulose, Dordrecht, v. 24, n. 6, p. 2437-2453, 2017.

KIM, H. J.; JIN, J. N.; KAN, E.; KIM, K. J.; LEE, S. H. Bacterial cellulose-chitosan composite hydrogel beads for enzyme immobilization. Biotechnology and Bioprocess Engineering, Seoul, v. 22, p. 89-94, 2017.

KIM, J. S.; LEE, Y. Y.; KIM, T. H. A review on alkaline pretreatment technology for bioconversion of lignocellulosic biomass. Bioresource Technology, Amsterdam, v. 199, p. 42-48, 2016.

KIM, Y.; JEONG, D.; PARK, K. H.; YU, J.-H.; JUNG, S. Efficient adsorption on benzoyl and stearoyl cellulose to remove phenanthrene and pyrene from aqueous solution. Polymers, Basel, v. 10, p. 1042-1055, 2018.

KLEMM, D.; PHILIPP, B.; HEINZE, T.; HEINZE, U.; WAGENKNECHT, W. Comprehensive cellulose chemistry. Weinheim: Wiley-VCH, 1998. v. 1

KOLPAK, F. J.; WEIH, M.; BLACKWELL, J. Mercerization of cellulose: 1. Determination of the structure of mercerized cotton. Polymer, London, v. 19, n. 2, p. 123-131, 1978.

KONOVALOVA, V.; GUZIKEVIC, K.; BURBAN, A.; KUJAWSKI, W.; JARZYNKA, K.; KUJAWA, J. Enhanced starch hydrolysis using $\alpha$-amylase immobilized on cellulose ultrafiltration affinity membrane. Carbohydrate Polymers, Oxford, v. 152, p. 710-717, 2016.

KOSTAG, M.; GERICKE, M.; HEINZE, T.; EL SEOUD, O. A. Twenty-five years of cellulose chemistry: innovations in the dissolution of the biopolymer and its transformation into esters and ethers. Cellulose, Dordrecht, v. 26, p. 139-184, 2019.

KROON-BATENBURG, L. M. J.; KROON, J. The crystal and molecular structures of cellulose I and II. Glycoconjugate Journal, New York, v. 14, n. 5, p. 677-690, 1997. 
KUMAR, A.; DHAR, K.; KANWAR, S. S.; ARORA, P. K. Lipase catalysis in organic solvents: advantages and applications. Biological Procedures Online, London, v. 15, n. 2, p. 1-11, 2016.

LACERDA, T. M. Hidrólise de polpa de sisal como via de produção de etanol e materiais. 2012. Tese (Doutorado em Química) - Instituto de Química de São Carlos, Universidade de São Paulo, São Carlos, 2012.

LANGAN, P.; NISHIYAMA, Y.; CHANZY, H. X-ray structure of mercerized cellulose ii at 1 A resolution. Biomacromolecules, Washington, v. 2, n. 2, p. 410-416, 2001.

LAVANYA, R.; CLARA, I.; NATCHIMUTHU, N. Shear-induced morphology changes in N,N-dimethylacetamide/lithium chloride pretreated cellulose. Journal of Applied Polymer Science, Hoboken, v. 134, n. 19, p. 1-9, 2017.

LAW, K.-Y.; ZHAO, H. Surface wetting: characterization, contact angle, and fundamentals. Cham: Springer, 2016.

LEE, I.; EVANS, B. R.; WOODWARD, J. The mechanism of cellulase action on cotton fibers: evidence from atomic force microscopy. Ultramicroscopy, Amsterdam, v. 82, n. 2000, p. 213-221, 2000.

LEE, K.; BLAKER, J. J.; BISMARCK, A. Surface functionalisation of bacterial cellulose as the route to produce green polylactide nanocomposites with improved properties. Composites Science and Technology, Oxford, v. 69, p. 2724-2733, 2009.

LEPPÄNEN, K.; ANDERSSON, S.; TORKKELI, M.; KNAAPILA, M.; KOTELNIKOVA, N.; SERIMAA, R. Structure of cellulose and microcrystalline cellulose from various wood species, cotton and flax studied by X-ray scattering. Cellulose, Dordrecht, v. 16, p. 999-1015, 2009.

\section{LI, Z.; WANG, C. One-dimensional nanostructures electrospinning technique and} unique nanofibers. Berlin: Springer Berlin Heidelberg, 2013.

LIU, Q.; HAO, W.; YANG, Y.; RICHEL, A.; OUYANG, C.; LIU, H.; GUO, R.; XIA, X.; YANG, J.; SONG, J.; GOFFIN, D. Effects of size and dispersity of microcrystalline celluloses on size, structure and stability of nanocrystalline celluloses extracted by acid hydrolysis. Nano LIFE, Singapore, v. 4, n. 4, p. 14410-14414, 2014.

LIU, Y.; HU, H. X-ray diffraction study of bamboo fibers treated with $\mathrm{NaOH}$. Fibers and Polymers, Heidelberg, v. 9, n. 6, p. 735-739, 2008.

LIU, Y.; ZHOU, J.; FU, W.; ZHANG, P.; PAN, X.; XIE, E. In situ synthesis of CoSx@carbon core-shell nanospheres decorated in carbon nano fi bers for capacitor electrodes with superior rate and cycling performances. Carbon, Oxford, v. 114, p. 187-197, 2017. 
LOMELÍ-RAMÍREZ, M. G.; VALDEZ-FAUSTO, E. M.; RENTERÍA-URQUIZA, M.; JIMÉNEZ-AMEZCUA, R. M.; ANZALDO HERNÁNDEZ, J.; TORRES-RENDON, J. G.; GARCÍA ENRIQUEZ, S. Study of green nanocomposites based on corn starch and cellulose nanofibrils from Agave tequilana Weber. Carbohydrate Polymers, Oxford, v. 201, p. 9-19, 2018.

LUCENA, M. C. C.; ALENCAR, A. E. V. De; MAZZETO, S. E.; SOARES, S. A. The effect of additives on the thermal degradation of cellulose acetate. Polymer Degradation and Stability, London, v. 80, n. 1, p. 149-155, 2003.

LUO, X.; LEI, X.; CAI, N.; XIE, X.; XUE, Y.; YU, F. Removal of heavy metal ions from water by magnetic cellulose- based beads with embedded chemically modi fi ed magnetite nanoparticles and activated carbon. ACS Sustainable Chemistry \& Engineering, Washington, v. 4, p. 3960-3969, 2016.

MAMLEEV, V.; BOURBIGOT, S.; YVON, J. Kinetic analysis of the thermal decomposition of cellulose: the main step of mass loss. Journal of Analytical and Applied Pyrolysis, Amsterdam, v. 80, n. 1, p. 151-165, 2007.

MANO, E. B.; MENDES, L. C. Introdução a polímeros. 2. ed. São Paulo: Edgard Blücher, 1999.

MARK, H. F.; BIKALES, N. M.; OVERBERGER, C. G.; MENGES, G.; KROSCHWITZ, J. I. Encyclopedia of polymer science and engineering. 2. ed. New York: Willey, 1988.

MEDRONHO, B.; LINDMAN, B. Competing forces during cellulose dissolution: from solvents to mechanisms. Current Opinion in Colloid \& Interface Science, Oxford, v. 19, n. 1, p. 32-40, 2014. a.

MEDRONHO, B.; LINDMAN, B. Brief overview on cellulose dissolution/regeneration interactions and mechanisms. Advances in Colloid \& Interface Science, Oxford, p. 1-7, 2014. b.

MEDRONHO, B.; ROMANO, A.; GRAC, M. Rationalizing cellulose (in)solubility: reviewing basic physicochemical aspects and role of hydrophobic interactions. Cellulose, Dordrecht, v. 19, p. 581-587, 2012.

MEHTA, A.; BODH, U.; GUPTA, R. Fungal lipases: a review. Journal of Biotech Research, Edmond, v. 8, p. 58-77, 2017.

MIHRANYAN, A. Cellulose from cladophorales green algae: from environmental problem to high-tech composite materials. Journal of Applied Polymer Science, Hoboken, v. 119, n. 4, p. 2449-2460, 2011.

MIKAEILI, F.; GOUMA, P. I. Super water-repellent cellulose acetate mats. Scientific Reports, London, v. 8, p. 1-8, 2018. 
MIT-UPPATHAM, C.; NITHITANAKUL, M.; SUPAPHOL, P. Ultrafine electrospun polyamide- 6 fibers: effect of solution conditions on morphology and average fiber diameter. Macromolecular Chemistry and Physics, Weinheim, v. 6, p. 2327-2338, 2004.

MITCHELL, G. R. Electrospinning: principles, practice and possibilities. Cambridge: The Royal Society of Chemistry, 2015.

MOHAMADA, N. R.; MARZUKIA, N. H. C.; BUANG, N. A.; HUYOP, F.; WAHABA, F. $\mathrm{H}$. An overview of technologies for immobilization of enzymes and surface analysis techniques for immobilized enzymes. Biotechnology \& Biotechnological Equipment, Abingdon, v. 29, p. 37-41, 2015.

MONTAÑO-LEYVA, B.; RODRIGUEZ-FELIX, F.; TORRES-CHÁVEZ, P.; RAMIREZWONG, B.; LÓPEZ-CERVANTES, J.; SANCHEZ-MACHADO, D. Preparation and Characterization of durum wheat (Triticum durum) straw cellulose nanofibers by electrospinning. Journal of Agricultural and Food Chemistry, Washington, v. 59, p. 870$875,2011$.

MOON, R. J.; MARTINI, A.; NAIRN, J.; SIMONSEN, J.; YOUNGBLOOD, J. Cellulose nanomaterials review: structure, properties and nanocomposites. Chemical Society Reviews, Cambridge, v. 40, n. 7, p. 3941-94, 2011.

MORAIS, J. P. S. M.; ROSA, M. D. F.; SOUZA FILHO, M. S. M.; NASCIMENTO, L. D.; NASCIMENTO, D. M.; CASSALES, A. R. Extraction and characterization of nanocellulose structures from raw cotton linter. Carbohydrate Polymers, Oxford, v. 91, n. 1, p. 229-235, 2013.

MORGADO, D. L. Biocompósitos a partir de celulose de linter: filmes de acetatos de celulose/celulose e quitosana/celulose. 2009. Tese (Doutorado em Química) - Instituto de Química de São Carlos, Universidade de São Paulo, São Carlos, 2009.

MORGENSTERN, B.; KAMMER, H. W. Solvation in cellulose-LiCl-DMAc solutions. Trends in Polymer Science, Oxford, v. 4, n. 3, p. 87-91, 1996.

NAGARAJAN, S.; SKILLEN, N. C.; IRVINE, J. T. S.; LAWTON, L. A. Cellulose II as bioethanol feedstock and its advantages over native cellulose. Renewable and Sustainable Energy Reviews, Oxford, v. 77, p. 182-192, 2017.

NAM, S.; FRENCH, A. D.; CONDON, B. D.; CONCHA, M. Segal crystallinity index revisited by the simulation of X-ray diffraction patterns of cotton cellulose $\mathrm{I} \beta$ and cellulose II. Carbohydrate Polymers, Oxford, v. 135, p. 1-9, 2016.

NASIR, M.; SUBHAN, A.; PRIHANDOKO, B.; LESTARININGSIH, T. Nanostructure and property of electrospun $\mathrm{SiO}_{2}$-cellulose acetate nanofiber composite by electrospinning. Energy Procedia, Amsterdam, v. 107, n. 2016, p. 227-231, 2017.

NEVELL, T. P.; ZERONIAN, S. H. Cellulose chemistry and its applications. New York: John Wiley, 1985. 
NORTHOLT, M. G.; BOERSTOEL, H.; MAATMAN, H.; HUISMAN, R.; VEURINK, J.; ELZERMAN, $\mathrm{H}$. The structure and properties of cellulose fibres spun from an anisotropic phosphoric acid solution. Polymer, London, v. 42, p. 8249-8264, 2001.

O’SUllivan, A. C. Cellulose: the structure slowly unravels. Cellulose, Dordrecht, v. 4, n. 3, p. 173-207, 1997.

OLSSON, C.; WESTMAN, G. Direct dissolution of cellulose: background, means and applications. In: VAN DE VEN, T. (ed.). Cellulose: fundamental aspects. Rijeka: InTech, 2013. p. 143-178.

OUAJAI, S.; SHANKS, R. A. Preparation, structure and mechanical properties of all-hemp cellulose biocomposites. Composites Science and Technology, Oxford, v. 69, n. 13, p. 2119-2126, 2009.

PALANISAMY, S.; RAMARAJ, S. K.; CHEN, S.; YANG, T. C. K.; YI-FAN, P.; CHEN, T.; VELUSAMY, V.; SELVAM, S. A novel laccase biosensor based on laccase immobilized graphene-cellulose microfiber composite modified screen-printed carbon electrode for sensitive determination of catechol. Scientific Reports, London, n. 1, p. 1-12, 2017.

PAYEN, A. Memoire sur la composition du tissu propre des plantes et du ligneux. Comptes Rendus Hebdomadaires des Séances de l'Académie des Sciences, Paris, v. 7, n. 7, p. 10521056, 1838.

PENG, S.; LI, L.; LEE, J.; YOONG, K.; TIAN, L.; SRINIVASAN, M.; ADAMS, S. Electrospun carbon nanofibers and their hybrid composites as advanced materials for energy conversion and storage. Nano Energy, Amsterdam, v. 22, p. 361-395, 2016.

PHAM, Q. P.; SHARMA, U.; MIKOS, A. G. Electrospinning of polymeric nanofibers for tissue engineering applications: a review. Tissue Engineering, New Rochelle, v. 12, n. 5, p. 1197-1211, 2006.

POOJARY, M. M.; ROOHINEJAD, S.; KOUBAA, M.; BARBA, F. J.; PASSAMONTI, P.; JAMBRAK, A. R.; OEY, I.; GREINER, R. Impact of pulsed electric fields on enzymes. In: MIKLAVCIC, D. Handbook of electroporation. Cham: Springer, 2017. p. 2369-2389.

POTTHAST, A.; ROSENAU, T.; BUCHNER, R.; RÖDER, T.; EBNER, G.;

BRUGLACHNER, H.; SIXTA, H.; KOSMA, P. The cellulose solvent system N,Ndimethylacetamide/lithium chloride revisited: the effect of water on physicochemical properties and chemical stability. Cellulose, Dordrecht, v. 9, p. 41-53, 2002.

POUDEROYEN, G.; EGGERT, T.; JAEGER, K.-E.; DIJKSTRA, B. W. The crystal structure of Bacillus subtilis lipase: a minimal a/b hydrolase fold enzyme. Journal of Molecular Biology, London, v. 309, p. 215-226, 2001.

QAYED, W. S.; ABORAIA, A. S.; ABDEL-RAHMAN, H. M.; YOUSSEF, A. F.; RES, J. C. $P$. Lipases-catalyzed enantioselective kinetic resolution of alcohols. Journal of Chemical and Pharmaceutical Research, Jaipur, v. 7, n. 5, p. 311-322, 2015. 
QIN, C.; SOYKEABKAEW, N.; XIUYUAN, N.; PEIJS, T. The effect of fibre volume fraction and mercerization on the properties of all-cellulose composites. Carbohydrate Polymers, Oxford, v. 71, n. 3, p. 458-467, 2008.

RAMOS, L. A.; ASSAF, J. M.; EL SEOUD, O. A.; FROLLINI, E. Influence of the supramolecular structure and physicochemical properties of cellulose on its dissolution in a lithium chloride/N,N-dimethylacetamide solvent system. Biomacromolecules, Washington, v. 6 , n. 5, p. 2638-2647, 2005.

RAMOS, L. A.; MORGADO, D. L.; EL SEOUD, O. A.; DA SILVA, V. C.; FROLLINI, E. Acetylation of cellulose in LiCl-N,N-dimethylacetamide: first report on the correlation between the reaction efficiency and the aggregation number of dissolved cellulose. Cellulose, Dordrecht, v. 18, n. 2, p. 385-392, 2011. a.

RAMOS, L. A.; MORGADO, D. L.; GESSNER, F.; FROLLINI, E.; EL SEOUDB, O. A. A physical organic chemistry approach to dissolution of cellulose: Effects of cellulose mercerization on its properties and on the kinetics of its decrystallization. Arkivoc, Gainesville, v. 2011, n. 7, p. 416-425, 2011. b.

RAMOS, L. A. Correlação entre propriedades físico-químicas de celulose e sua solubilização e derivativação em DMAc/LiCl e DMSO/TBAF.3.H2O. 2005. Tese (Doutorado em Química) - Instituto de Química de São Carlos, Universidade de São Paulo, São Carlos, 2005.

RENEKER, D. H.; YARIN, A. L. Electrospinning jets and polymer nanofibers. Polymer, London, v. 49, p. 2387-2425, 2008.

RIBEIRO, S. S.; RAMINELLI, C.; PORTO, A. L. M. Enzymatic resolution by CALB of organofluorine compounds under conventional condition and microwave irradiation. Journal of Fluorine Chemistry, Amsterdam, v. 154, p. 53-59, 2013.

RIVERO, P. J.; URRUTIA, A.; GOICOECHEA, J.; ARREGUI, F. J. Nanomaterials for functional textiles and fibers. Nanoscale Research Letters, Heidelberg, v. 10, n. 1, p. 501$523,2015$.

ROCHA, L. C.; ROSSET, I. G.; LUIZ, R. F.; RAMINELLI, C.; PORTO, A. L. M. Tetrahedron: asymmetry kinetic resolution of iodophenylethanols by Candida antarctica lipase and their application for the synthesis of chiral biphenyl compounds. Tetrahedron: Asymmetry, Oxford, v. 21, n. 8, p. 926-929, 2010.

RODRIGUES, B. V. M. Valorização de fibras de sisal: síntese de ésteres de celulose e preparação de materiais. 2014. Tese (Doutorado em Química) - Instituto de Química de São Carlos, Universidade de São Paulo, São Carlos, 2014.

RODRIGUES, B. V. M.; HEIKKILÄ, E.; FROLLINI, E.; FARDIM, P. Multi-technique surface characterization of bio-based films from sisal cellulose and its esters: a FE-SEM, $\mu$ XPS and ToF-SIMS approach. Cellulose, Dordrecht, v. 21, n. 3, p. 1289-1303, 2014. 
RODRIGUES, B. V. M.; RAMIRES, E. C.; SANTOS, R. P. O.; FROLLINI, E. Ultrathin and nanofibers via room temperature electrospinning from trifluoroacetic acid solutions of untreated lignocellulosic sisal fiber or sisal pulp. Journal of Applied Polymer Science, Hoboken, v. 132, n. 16, p. 41826-41834, 2015.

ROJAS-MERCADO, A. S.; MORENO-CORTEZ, I. E.; LUCIO-, R.; PAVÓN, L. L. Encapsulation and immobilization of ficin extract in electrospun polymeric nanofibers. International Journal of Biological Macromolecules, Amsterdam, v. 118, p. 2287-2295, 2018.

RULAND, W. X-ray determination of crystallinity and diffuse disorder scattering. Acta Crystallographica, Malden, v. 14, p. 1180-1185, 1961.

SAIRAM, M.; SREEDHAR, B.; RAO, D. V. M.; PALANIAPPAN, S. Synthesis and Thermal Degradation Kinetics of Cellulose Esters. Polymer for Advanced Technologies, Oxford, v. 14, p. 477-485, 2003.

SAMARANAYAKE, G.; GLASSER, W. G. Cellulose derivatives with low DS. I. A novel acylation system. Carbohydrate Polymers, Oxford, v. 22, n. 1, p. 1-7, 1993.

SANTMARTÍ, A.; LEE, K. Nanocellulose and sustainability. Boca Raton: CRC Press, 2018.

SANTOS, R. P. O.; RODRIGUES, B. V. M.; SANTOS, D. M.; CAMPANA-FILHO, S. P.; RUVOLO-FILHO, A. C.; FROLLINI, E. Electrospun recycled PET-based mats: tuning the properties by addition of cellulose and/or lignin. Polymer Testing, London, v. 60, p. 422$431,2017$.

SASSOLAS, A.; BLUM, L. J.; LECA-BOUVIER, B. D. Immobilization strategies to develop enzymatic biosensors. Biotechnology Advances, New York, v. 30, n. 3, p. 489-511, 2012.

SATARI, B.; KARIMI, K.; KUMAR, R. Cellulose solvent-based pretreatment for enhanced second-generation biofuel production: a review. Sustainable Energy \& Fuels, Cambridge, v. 3 , n. 1, p. 11-62, 2019.

SCHEIRS, J.; CAMINO, G.; TUMIATTI, W. Overview of water evolution during the thermal degradation of cellulose. European Polymer Journal, Oxford, v. 37, p. 933-942, 2001.

SCHINDELIN, J.; ARGANDA-CARRERAS, I.; FRISE, E.; KAYNIG, V.; LONGAIR, M.; PIETZSCH, T.; PREIBISCH, S.; RUEDEN, C.; SAALFELD, S.; SCHMID, B.; TINEVEZ, J.; WHITE, D. J.; HARTENSTEIN, V.; ELICEIRI, K.; TOMANCAK, P.; CARDONA, A. Fiji: an open-source platform for biological-image analysis. Nature Methods, London, v. 9, n. 7, p. 676-682, 2012.

SCHMID, A.; DORDICK, J. S.; HAUER, B.; KIENER, A.; WUBBOLTS, M.; WITHOLT, B. Industrial biocatalysis today and tomorrow. Nature, London, v. 409, p. 258-268, 2001. 
SCHNEIDER, C. A.; RASBAND, W. S.; ELICEIRI, K. W. NIH Image to ImageJ: 25 years of image analysis. Nature Methods, London, v. 9, n. 7, p. 671-675, 2012.

SCHRAG, J. D.; CYGLER, M. Lipase and $\alpha / \beta$ Hydrolase Fold. Methods in enzymology, Maryland Heights, v. 284, n. 1973, p. 85-107, 1997.

SEGAL, L.; CREELY, J. J.; MARTIN, A. E.; CONRAD, C. M. Empirical method for estimating the degree of crystallinity of native cellulose using the X-ray diffractometer.

Textile Research Journal, London, v. 29, n. 10, p. 786-794, 1959.

SHEN, D. K.; GU, S. The mechanism for thermal decomposition of cellulose and its main products. Bioresource Technology, Amsterdam, v. 100, n. 24, p. 6496-6504, 2009.

SHIBAZAKI, H.; KUGA, S.; OKANO, T. Mercerization and acid hydrolysis of bacterial cellulose. Cellulose, Dordrecht, v. 4, n. 2, p. 75-87, 1997.

SILBERMANN, S.; WEILACH, C.; KLIBA, G.; FACKLER, K.; POTTHAST, A. Improving molar mass analysis of cellulose samples with limited solubility. Carbohydrate Polymers, Oxford, v. 178, p. 302-310, 2017.

SILL, T. J.; RECUM, H. A. Electrospinning: applications in drug delivery and tissue engineering. Polymer, London, v. 29, p. 1989-2006, 2008.

SIXTA, H. Handbook of pulp. Lenzing: Wiley-VCH, 2006.

SON, W. K.; YOUK, J. H.; LEE, T. S.; PARK, W. H. Electrospinning of ultrafine cellulose acetate fibers: studies of a new solvent system and deacetylation of ultrafine cellulose acetate fibers. Journal of Polymer Science Part B: Polymer Physics, Hoboken, v. 42, n. 1, p. 5-11, 2004.

STANA-KLEINSCHEK, K.; STRNAD, S.; RIBITSCH, V. Surface characterization and adsorption abilities of cellulose fibers. Polymer Engineering and Science, Hoboken, v. 39, n. 8 , p. $1412-1424,1999$.

STEINBACH, A.; WINKENBACH, R.; EHMSEN, H. Materialeffizienz und nachhaltigkeit in der chemie: wo stehen wir heute? Chemie Ingenieur Technik, Weinheim, v. 83, n. 3, p. 295$305,2011$.

STERGIOU, P.; FOUKIS, A.; FILIPPOU, M.; KOUKOURITAKI, M.; PARAPOULI, M.; THEODOROU, L. G.; HATZILOUKAS, E.; AFENDRA, A.; PANDEY, A.; PAPAMICHAEL, E. M. Advances in lipase-catalyzed esterification reactions. Biotechnology Advances, New York, v. 8, p. 1846-1859, 2013.

TAYLOR, G. Electrically driven jets. Proceedings of the Royal Society A: Mathematical, Physical and Engineering Sciences, London, v. 313, p. 453-475, 1969.

TECHNICAL ASSOCIATION OF THE PULP AND PAPER INDUSTRY. TAPPI T 558 om-97 surface wettability and absorbency of sheeted materials using an automated contact angle tester. Peachtree Corners, 1997. 
TECHNICAL ASSOCIATION OF THE PULP AND PAPER INDUSTRY. TAPPI T 211 om-02 ash in wood, pulp, paper and paperboard: combustion at $525^{\circ} \mathrm{C}$. Peachtree Corners, 2002.

TECHNICAL ASSOCIATION OF THE PULP AND PAPER INDUSTRY. TAPPI T 429 cm-10 alpha-cellulose in paper. Peachtree Corners, 2010.

TECHNICAL ASSOCIATION OF THE PULP AND PAPER INDUSTRY. TAPPI T 550 om-08 Determination of equilibrium moisture in pulp, paper ad paperboard for chemical analysis. Peachtree Corners, 2013.

TERINTE, N.; IBBETT, R.; SCHUSTER, K. C. Overview on native cellulose and microcrystalline cellulose i structure studied by $\mathrm{x}$-ray diffraction (WAXD): comparison between measurement techniques. Lenzinger Berichte, Lenzing, v. 89, p. 118-131, 2011.

THAKUR, V. K.; THAKUR, M. K. Processing and characterization of natural cellulose fibers/thermoset polymer composites. Carbohydrate Polymers, Oxford, v. 109, p. 102-117, 2014.

THOMPSON, M. CHN elemental analysers: AMC technical briefs. London, Royal Society of Chemistry, 2008. Disponível em: www.rsc.org/amc. Acesso em: 03 jan. 2019.

TINGAUT, P.; ZIMMERMANN, T.; LOPEZ-SUEVOS, F. Synthesis and characterization of bionanocomposites with tunable properties from poly(lactic acid) and acetylated microfibrillated cellulose. Biomacromolecules, Washington, v. 11, n. 2, p. 454-464, 2010.

TRIVEDI, P.; FARDIM, P. Recent advances in cellulose chemistry and potential applications. In: ZHEN, F.; SMITH, R. L.; TIAN, X. (eds.). Production of materials from sustainable biomass resources. Singapore: Springer, 2019. p. 99-115.

TZE, W. T.; GARDNER, D. J. Contact angle and IGC measurements for probing surfacechemical changes in the recycling of wood pulp fibers. Journal of Adhesion Science and Technology, Abingdon, v. 15, n. 2, p. 223-241, 2001.

VONK, C. G. Computerization of Ruland's x-ray method for determination of the crystallinity in polymers. Journal of Applied Crystallography, Chichester, v. 6, p. 148-152, 1972.

WADA, M.; CHANZY, H.; NISHIYAMA, Y.; LANGAN, P. Cellulose III (I) crystal structure and hydrogen bonding by synchrotron x-ray and neutron fiber diffraction. Macromolecules, Washington, v. 37, n. 23, p. 8548-8555, 2004.

WADA, M.; HEUX, L.; NISHIYAMA, Y.; LANGAN, P. X-ray Crystallographic, scanning microprobe $\mathrm{X}$-ray diffraction, and cross-polarized / magic angle spinning 13 C NMR studies of the structure of cellulose III (II). Biomacromolecules, Washington, v. 10, p. 302-309, 2009.

WADA, M.; OKANO, T.; SUGIYAMA, J. Allomorphs of native crystalline cellulose I evaluated by two equatorial d-spacings. Journal of Wood Science, Tokyo, v. 47, n. 2, p. 124-128, 2001. 
WANG, Y.; HSIEH, Y. Immobilization of lipase enzyme in polyvinyl alcohol (PVA) nanofibrous membranes. Journal of Membrane Science, Amsterdam, v. 309, p. 73-81, 2008 .

WANG, Z.; WANG, J.; XU, Z. Immobilization of lipase from Candida rugosa on electrospun polysulfone nanofibrous membranes by adsorption. Journal of Molecular Catalysis B: Enzymatic, Amsterdam v. 42, p. 45-51, 2006.

WEI, W.; YEH, J.; LI, P.; LI, M.; LI, W.; WANG, X. Effect of nonsolvent on morphologies of polyamide 6 electrospun fibers. Journal of Applied Polymer Science, Hoboken, v. 118, p. 3005-3012, 2010.

WENDEL, J. F.; GROVER, C. E. taxonomy and evolution of the cotton genus, gossypium. In: FANG, D.; PERCY, R. (eds.). Cotton. 2. ed. Madison: ASA-SSSA-CSSA, 2015. p. 2544.

WHITTALL, J.; SUTTON, P. Practical methods for biocatalysis and biotransformations. New York: Wiley, 2009.

WOODINGS, C. Regenerated cellulose fibres. Boca Raton: CRC Press, 2001.

WU, R.; HE, B.; ZHANG, B.; ZHAO, G.; LI, X. Preparation of immobilized pectinase on regenerated cellulose beads for removing anionic trash in whitewater from papermaking. Journal of Chemical Technology \& Biotechnology, Oxford, v. 89, p. 1103-1109, 2013.

YAN, J.; HORÁK, D.; HAMMOND, M. A tosyl-activated magnetic bead cellulose as solid support for sensitive protein detection. Journal of Biotechnology, Amsterdam, v. 167, p. 235-240, 2013.

YANG, C.; YEN, C.; JHENG, J.; WANG, C.; CHEN, S.; HUANG, P.; HUANG, K.; SHAW, J. Immobilization of Brassica oleracea Chlorophyllase 1 (BoCLH1) and Candida rugosa Lipase (CRL) in magnetic alginate beads: an enzymatic evaluation in the corresponding proteins. Molecules, Basel, v. 19, p. 11800-11815, 2014.

YE, P.; XU, Z.; WU, J.; INNOCENT, C.; SETA, P. Nanofibrous poly (acrylonitrile- co maleic acid) membranes functionalized with gelatin and chitosan for lipase immobilization. Biomaterials, Amsterdam, v. 27, p. 4169-4176, 2006.

YOUNESI, M.; WU, X.; AKKUS, O. Controlled mercerization of bacterial cellulose provides tunability of modulus and ductility over two orders of magnitude. Journal of the Mechanical Behavior of Biomedical Materials, Amsterdam, v. 90, n. 2017, p. 530-537, 2019.

YUAN, Y.; LEE, T. R. Contact angle and wetting properties. In: BRACCO, G.; HOLST, B. (eds.). Surface science techniques. Berlin: Springer, 2013. p. 3-34.

YUE, Y.; ZHOU, C.; FRENCH, A. D.; XIA, G.; HAN, G.; WANG, Q.; WU, Q. Comparative properties of cellulose nano-crystals from native and mercerized cotton fibers. Cellulose, Dordrecht, v. 19, n. 4, p. 1173-1187, 2012. 
ZERONIAN, S. H.; RYU, H. Properties of cotton fibers containing the cellulose IV crystal structure. Journal of Applied Polymer Science, Hoboken, v. 33, n. 7, p. 2587-2604, 1987.

ZHANG, C.; LIU, R.; XIANG, J.; KANG, H.; LIU, Z.; HUANG, Y. Dissolution mechanism of cellulose in N,N-dimethylacetamide/lithium chloride: revisiting through molecular interactions. Journal of Physical Chemistry B, Washington, v. 118, n. 31, p. 9507-9514, 2014. a.

ZHANG, J.; SONG, M.; WANG, X.; WU, J.; YANG, Z.; CAO, J.; CHEN, Y.; WEI, Q. Preparation of a cellulose acetate/organic montmorillonite composite porous ultrafine fiber membrane for enzyme immobilization. Journal of Applied Polymer Science, Hoboken, v. 133, n. 33, p. 1-8, 2016.

ZHANG, J.; WU, J.; CAO, Y.; SANG, S.; ZHANG, J.; HE, J. Synthesis of cellulose benzoates under homogeneous conditions in an ionic liquid. Cellulose, Dordrecht, v. 16, p. 299-308, 2009.

ZHANG, Q.; SHI, F.; WANG, P.; LIN, D.; YAO, S. Preparation of cellulose adsorbents with ionic liquid and pore expansion for chromatographic applications. Journal of Applied Polymer Science, Hoboken, p. 40060-8, 2014. b.

ZHANG, X.; LI, J.; YANG, W.; BLASIAK, W. Formation mechanism of levoglucosan and formaldehyde during cellulose pyrolysis. Energy \& Fuels, Cambridge, v. 25, n. 8, p. 3739 3746, 2011.

ZHAO, H.; KWAK, J. H.; WANG, Y.; FRANZ, J. A.; WHITE, J. M.; HOLLADAY, J. E. Effects of crystallinity on dilute acid hydrolysis of cellulose by cellulose ball-milling study. Energy \& Fuels, Cambridge, n. 15, p. 807-811, 2006.

ZUGENMAIER, P. Crystalline cellulose and derivatives. Berlin: Springer Berlin Heidelberg, 2008. 